QK

574

I 73 C 68

1912

BOT

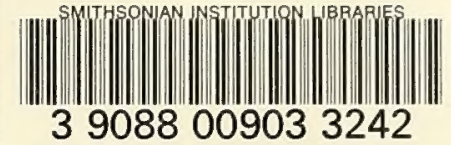

39088009033242

Cotton, A. .

Marine Algae. 



\section{PROCEEDINGS}

\section{OF THB \\ ROYAL IRISH ACADEMY \\ Volume XXXI}

CLARE ISLAND SURVEY

PART 15

MARINE ALGAE

BY

A. D. COTTON

DUBLIN: HODGES, FIGGIS, \& CO, LTD.

LONDON: WILLIAMS \& NORGATE

1912

Price Five Shillings

[For scheme of publication of this series see inside of wrapper] 


\section{ROYAL IRISH ACADEMY CLARE ISLAND SURVEY}

Tris survey of the Fauna Flora, Geology, Meteorology, \&c., of Clare Island and the adjoining mainland in the West of Ireland was carried out by over one hundred specialists during the jears 1909, 1910, and 1911. It was undertaken in order to furmish a study of a typical area of the west coast of Ireland, a region which provides some of the most interesting faunistic and floristic problems in Europe; and also as a contribution towards the study of island faunas and foras - a subject of wide and absorbing interest.

The report when finished will provide the most complete survey of the Fauna and Flora of a definite area which has ever been made. In addition to systematic zoology and botany, special attention has been given to questions of geographical distribution, dispersal, and ecology, and to the influence of human operations upon the Fauna and Flora. The complete report is estimated to run to about 1600 pages with 100 plates, and will cost $60 /$ or more. The whole series may be subscribed for at the reduced price of $50 /$ - paid in advance, on receipt of which the reports issued up to the present will be forwarded, and future parts sent as soon as published. Each part will also be sold separately.

The reports when complete will include descriptions of some 50 species of animals and plants new to science; also records of about 200 species new to the British Isles, and at least 1,000 species new to Ireland.

The list printed on pages 3 and 4 of this wrapper shows the scope of the work, the present state of publication, and the prices of the parts published so far.

Communications relative to this publication to bo addressed to the publishers or to

\section{The Smoriwatix}

ROYAL IRISH ACADEMY,

DAWSON STREET,

DUBLIN. 


\title{
MARINE ALGAE.
}

\author{
Br A. D. COTTON.
}

Plates I.-XI.

Read Juve 24 and Novemmer 11. Published Noveminak 27, 1912.

\section{CONTEN'TS.}

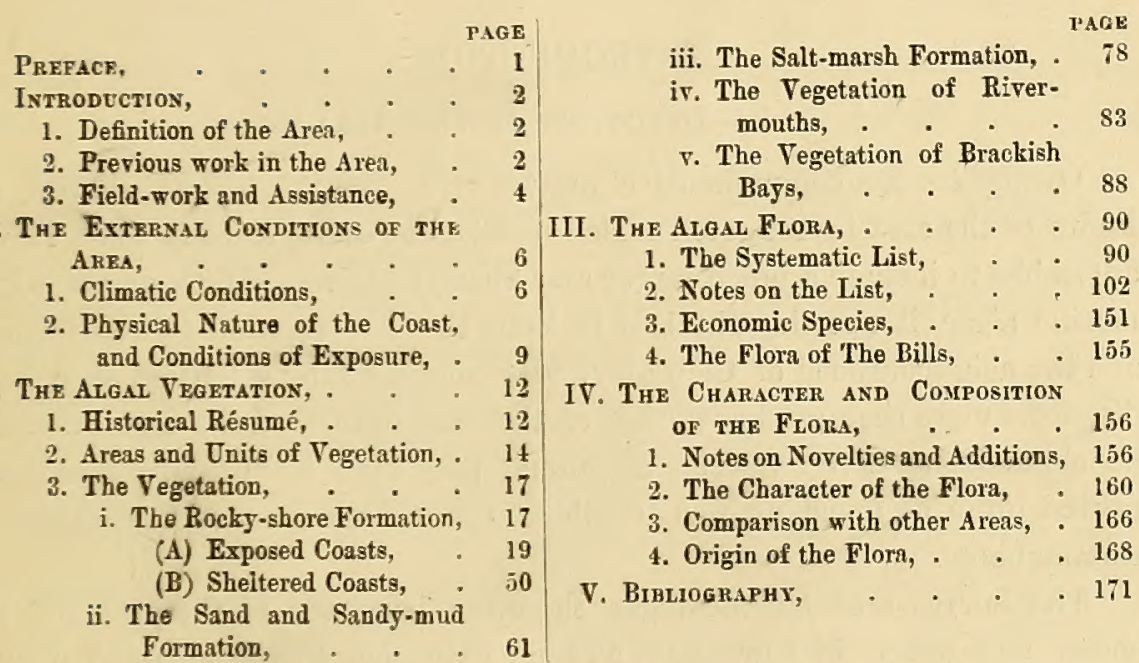

\section{PREFACE.}

THE natural history Survey of Clare Island and the adjoining mainland provided an opportunity of investigating one of the most interesting algological regions in the British Isles. Since the first decade of the last century, when Miss Hutchins collected in Bantry Bay, and more especially since the days when Harvey published his famous "Phycologia Pritannica," the west of Ireland has always possessed a great attraction for the marine botanist. But although various collections and many gatherings of new and rare species have been dealt with, no systematic investigation of that area has been undertaken, nor has any list or general account of the algal flora been published. The selection of Clare Island as a centre for a detailed survey was therefore particularly satisfactory from an algological standpoint. Results for the systematist and student of plant-distribution were certain, and the 
variety of ground in the neighbourhood provided ample scope for the modern study of plant-communities. The position of the island-off the coast of Co. Mayo, and in the Gulf Stream drift-ensured the presence of that southern element which gives the Irish flora its peculiar interest.

The following report shows that the hopes raised have been amply fulfilled. 'The flora proved quite as rich as was expected; and practically all the species for which the west of Ireland is noted occur within the surveyarea. Valuable systematic results have been obtained; and the variety of algal associations present rendered the study of the marine vegetation one of the most comprehensive that has yet been carried out. Important phytogeographic data also, necessitating the modifying of previous views, were secured.

\section{INTRODUCTION.}

\section{1.-Definition of the Area.}

Owing to the corrprehensive nature of a natural history survey, the limits of the area investigated varied in different cases, since in some it was advisable to include a much larger area than in others. With regard to the marine algae, it was thought best to limit the investigation to Clare Island and the neighbourhood of Clew Bay. By concentrating attention on a small district a more accurate knowledge of the true nature of the vegetation can be obtained, and the variety of ground presented in the area mentioned proved quite as much as was possible to work with a moderate degree of thoroughmess.

The Survey-area for the algae, therefore, consisted of Clare Island, the shores and waters of Clew Bay, and an extension to the north to include Bellacragher Bay and Achill Sound.

At the same time it appeared advisable not to overlook the interesting records from Roundstone, a locality only twenty-five miles south of Clew Bay. This district was carefully worked some seventy years ago by W. McCalla, and he collected several species which were not found in the Clare Island district. A brief visit was paid to Roundstone; and all records from that locality are included in the report.

\section{2.-Previous Work in the Area.}

According to the scheme of geographical areas devised by Adams (see Adams, '11, in Bibliography) the province of Connaught is divided into three sub-divisions. Co. Mayo (which includes the survey-area proper) forms subdivision $\mathrm{C} \mathrm{2}_{2}$ and, according to an annotated copy of Adams' Synopsis (Adams, 
'08), kindly sent me by the author, possesses thirty records of algae. Co. Galway, on the other hand, which forms sub-division $\mathrm{C} 1$, has a much longer list, owing to the collections made at Roundstone Bay. For the third subdivision, C 3 (i.e., counties Sligo and Leitrim), there are practically no records.

With regard to sub-division $\mathrm{C} 2, \mathrm{Wm}$. Thompson, the zoologist, collected a few plants in Clew Bay about 1840; and Harvey quotes one recordAsperococcus bullosus -in "Phycologia Britannica." In a report of a natural history excursion to Achill at Easter, 1898, H. Hanna deals with the marine algae (Hanna, '98). He records twenty species; and this constitutes the only account of the sea-weeds of the area. Adams, in his list, adds nine names to the flora of the sub-division, eulled from various sources. A single species has been recorded from Clare Island, namely Codium tomentosum (vide H. H. Dixon, Ann. Bot., xi, p. 590).

The Roundstone records date from 1808. Fucus Mackaii was described from that locality by Dawson Turner ("Historia Fucorum," Pl. 52); and it still remains one of the few stations for the plant in Ireland. In addition to the discovery of this species, Mackay noted the presence of Fihodochorton floridulum, which Harvey mentions in the chapter on algae in Mackay's "Flora Hibernica." McCalla's records follow. He thoroughly explored the shore, and supplied Harvey, as the pages of "Phycologia Britannica" testify, with much valuable material both from Roundstone Bay and Birturbuy Bay. MeCalla was also one of the pioneers of dredging amongst algologists, and by this method he obtained many interesting species. He commenced to issue a set of "Algae Hibernicae," but, owing to his untimely death in 1849, only two volumes were published. Harvey visited Roundstone at least once, and in later times, Johnson ('93) and H. Hanna. Foslie also, the well-known specialist on calcareous algae, came over from Norway on purpose to investigate the Lithothamnia which had been described from Roundstone by McCalla and Harvey. An account of his trip was published in the "Irish Naturalist" ('99, p. 175). Foslie was keenly interested in the Lithothamnia of the British Isles, and it was proposed to send him for identification all the Clew Bay material. His premature death in 1910 came as a great shock. Three days were spent by me at Roundstone in September, 1911, and, with the exception of Codium amphibium, all the species for which that locality is famous were seen in their natural habitat. The total number of species listed by J. Adams for the sub-division $\mathrm{C} 1$ is 162 .

Outside the province of Connaught, Valencia Harbour (in the extreme south-west) has been specially investigated by biologists, and Weiss, who dealt with the algae ['00], gives a list of eighty-six species collected by him during August and September, 1896, with notes on the same. 


\section{Field-Work and Assistance.}

My visits to the Survey-area extended over three years. In each year two visits, varying from a fortnight to three weeks, were paid to the island and mainland, whilst during the last year, an additional winter visit was accomplished. Owing to the uncertainty of communication, no attempt was made during this last trip to cross to the island, but since the conditions of the exposed mainland are similar to those of Clare Island, a fair idea of the winter aspect of the vegetation of the whole area was obtained. In addition, Mr. J. Adams, of the Royal College of Science, Dublin, visited the district in August, 1909, investigating the island and dredging in Clew Bay.

The dates of the visits were as follows :-

1909. April 8-20; July 12-27. [August 20-27, J. Adams.]

1910. June 16-July 1; September 30-October 13.

1911. February 13-21; April 28-May 13; August 17-September 4.

About one-half the time of each trip was spent on the island, and the remainder either on the mainland or in dredging. Spring-tides were usually selected for the former locality, when exposed or semi-exposed shores were examined at low-water. As is well known, spring-tides are more useful in sheltered regions than in exposed, and a greater number of rare and sub-littoral species are doubtless uncovered during springs in Clew Bay than on Clare Island. But since these can readily be obtained by dredging, there was no object in reserving low-tides for mainland work.

Dredging was carried out in February, May, July, and August. For the more open waters I had the advantage of the ss. "Helga," of the Fisheries Branch of the Department of Agriculture and Technical Instruction for Ireland. The outer part of Clew Bay was explored, and a number of hauls were taken further out, i.e., to the south and west of Clare Island, and near The Bills, in depths ranging from 10 to 20 fathoms. A large amount of material was collected, and considerable light obtained as to the nature of the benthos, but for detailed study much longer time than was at my disposal was necessary. J. Adams also dredged from the "Helga" in 1909, and two interesting algae were found only on that occasion.

For the inner part of Clew Bay a small sailing-boat was used; and good work was accomplished by means of a hand-dredge in 1-5 fathoms. The "coral-banks" were investigated, and in quiet weather very much may be learned as to the nature of the flora. The February dredgings were useful in obtaining fruiting specimens of encrusting algae. In May the mass of vegetation is so great that it is impossible to do more than sample various localities. As the hauls of July, 1909, had provided several rare and interesting 
plants, a few days were set apart in August, 1911, to search for noteworthy absentees. Rough weather, however, set in, and dredging from a small boat was out of the question.

With regard to the nature of the field-work, the visits of the first year were mainly devoted to the listing of species from all parts of the area, and to working out critical forms. The same study was continued in 1910, and the analysis of algal communities was also taken in hand. The third year was principally devoted to the search for species which were to be expected but had not been found, and to the completion of the work on algal communities. On each visit, moreover, a large amount of material was collected for the Royal Botanic Gardens, Kew, as some extra leave had been granted for that purpose.

The time devoted to ecology necessarily robbed the systematic list of a certain number of names. Searching for rare or microseopic species invariably yields results in the way of new or little-known plants, but the records of minute species, such as Cyanophyceae, are not yet of much value for comparative purposes. Moreover, the amount of time and labour spent in working out microscopic forms is often very great, and out of proportion to the results obtained. Unfortunately there was no specialist for the Cyanophyceae (which are abundant in brackish parts of Clew Bay) who could be appealed to for aid.

The list, therefore, can hardly be considered as exhaustive. With regard to the littoral flora, the island-list must be fairly complete; and on the mainland the additions during the last trip were ehiefly microscopic forms. But in the sub-littoral region there are probably many species yet to be discovered, as the vegetation is very local and less easy of exploration. The fact that such conspicuous weeds as Dictyopteris, Acrothrix, Dasya corymbosa, and several others were only seen once, confirms this view.

Assistance.Dr. P. Kuckuck joined the collecting party during Junc, 1910 , and advantage was taken of his eritical knowledge of the Phoeophyceae to work out Ectocarpi, Chordarieae, \&c, and to make comparisons between the flora of the North Sea and Baltic, and that of Clare Island.

In April, 1911, Dr. F. Börgesen paid a visit to the Survey-area. Naturally the vegetation of Clare Island had been continually compared with the detailed account given by him for that of the Faeröes, and several striking contrasts had been noted. It was, therefore, of the greatest value to be able to examine the algal associations with Dr. Börgesen, and to discuss the problems that had arisen. His help also with regard to the Jceland flora was particularly useful.

In order to make the floristic section of the work as accurate as possible, 
which for comparative purposes is of the very greatest importance, I have availed myself freely of the help of specialists. Dr. Kuckuck kindly worked out the Ralfsiae, and checked a number of other members of the Phoeophyceae. The weight of his authority in doubtful cases was most valuable. I am also much indebted to Dr. M. Lemoine. Since the death of Foslie, the identification of encrusting Lithothamnia was uncertain work, owing to the confusion in the literature, and the scarcity of reliable material in British herbaria. Madame Lemoine willingly undertook to examine the Irish material, and, by her method of anatomical investigation, to work out and compare critical species with authentic specimens. Though no important additions to the list have resulted, it is highly satisfactory to have trustworthy identifications. An interesting point with regard to geographical distribution has, moreover, been cleared up by her. Dr. K. Rosenvinge kindly determined the Chantransiae, whilst Prof. N. Wille, Prof. C. Sauvageau, and Dr. H. H. Peterson examined the species of Ulothrix, Spacelaria, and Ceramium respectively. Prof. G. S. West's opinion on the brackish and freshwater species, and Mr. J. Adams' aid in connexion with the distribution of Irish plants were most helpful. Mr. E. M. Holmes has taken the keenest interest in the Clare Island flora, and throughout the work of identification has always most liberally bestowed the benefit of his valuable and unique experience. 'To all these botanists I offer my sincerest thanks. Special acknowledgments are due to Mr. R. Lloyd Praeger, the organizer and secretary of the Survey, to whom I am deeply indebted for advice on matters botanical and geological, as well as for encouragement and assistance in a number of ways.

\section{I.-THE EXTERNAL CONDITIONS OF THE AREA.}

\section{1.-Climatic Condilions.}

1. Atmospheric Temperaturc and Moistuie.-The insular elimate of Ireland, and the influence of the Gulf Stream drift, combine to render the Clare Island district particularly mild and damp. In winter rough stormy weather prevails, together with a large amount of rain, but frost is rare. In summer the weather is changeable, rain and gales from the south-west are frequent, and the average temperature relatively low. Though occasional warm days occur, spells of hot dry weather are most unusual; and this renders the intertidal region more favourable for vegetation than that of the south coast of England. A glance at the isotherms of Europe shows that the mean January temperature of $43^{\circ} \mathrm{F} .\left(=6 \cdot 11^{\circ} \mathrm{C}\right.$. $)$ corresponds with that of the south of France and the north of the Adriatic; whilst the July isotherm of $58^{\circ} \mathrm{F}$. 
( $=14.41^{\circ} \mathrm{C}$.) runs up the coast of Norway, across the north of Sweden to northern Russia and Siberia. Clare Island is sitnated on the same latitude as Heligoland and Kiel, but, as will be seen later, the Hora is of a very much more southern type.

The atmospheric moisture is of importance in connexion with the littoral vegetation. But the problem of desiccation during low water is a very complicated one, the latitude, together with the amount of wind and sunshine, haring to be taken into consideration. The following figures ("Irish Coast Pilot," ed. 6, 1911) give the mean humidity for the Blacksod Point Observatory for the last thirty-five years. It will be noted that the highest figures are those of the winter months, whereas in the Faeröes the reverse is the case, for which the absence in Ireland of summer fogs is probably responsible:-

\begin{tabular}{|ccc|c|c|c|c|c|c|c|c|c|c|}
\cline { 2 - 8 } & Jan. & Febr. & Mar. & Apr. & May. & June. & July. & Aug. & Sept. & Oct. & Nov. & Dec. \\
SS & Si & S6 & 86 & 81 & 81 & 84 & 83 & 84 & 81 & 86 & 85 \\
\hline
\end{tabular}

Note.-Observations made at 8 a.m. $100=$ Saturation point.

2. Temperature and Salinity of the Sea.-Important as are atmospheric conditions, the temperature of the water is even more intimately connected with the algal vegetation. The direct influence of the former is confined to the intertidal region, and is thus intermittent; but the effect of the latter is much more general, being felt both by the littoral and sub-littoral flora. A complete series of observations on sea-temperatures at different depths is not available for Clare Island; but the Meteorological Office has favoured me with details of the mean monthly surface-temperatures for Blacksod Bay and Cleggan during the year 1911 ; and Mr. G. P. Farran has kindly supplied me with two sets of temperatures and salinities for various depths in Clew Bay and off Clare Island. From these it is evident that the surface temperature does not differ much from that of 10-20 fathoms, so that the monthly table given below affords a good general guide. The Blacksod and Cleggan observatories are about twenty miles north and south respectively of Clare Island. It will be noted that many of the Blacksod figures are slightly higher than those of Cleggan, for which local topography doubtless accounts:-

Mean Surface Temperature, Blacksod and Cleggan, 1911. (Co).

\begin{tabular}{|l|c|c|c|c|c|c|c|c|c|c|c|c|c|}
\hline & Jan. & Febr. & Mar. & Apr. & May. & June & July. & A ug. & Sept. & Oct. & Nov. & Dec. \\
\hline Blacksod, & $7 \cdot 2$ & $6 \cdot 7$ & $6 \cdot 7$ & $8 \cdot 3$ & $11 \cdot 7$ & $13 \cdot 3$ & $16 \cdot 1$ & $16 \cdot 1$ & $13 \cdot 3$ & $10 \cdot 6$ & $7 \cdot 2$ & $6 \cdot 7$ \\
Cleggan, & $7 \cdot 2$ & $6 \cdot 7$ & $6 \cdot 7$ & $8 \cdot 3$ & $11 \cdot 1$ & $12 \cdot 2$ & $13 \cdot 3$ & $15 \cdot 0$ & $13 \cdot 9$ & $10 \cdot 6$ & $7 \cdot 2$ & $5 \cdot 6$ \\
\hline
\end{tabular}


Clare Island, Mat, 1909.

Station Number.

\begin{tabular}{|c|c|c|c|c|c|c|c|}
\hline \multirow{2}{*}{ Date. } & \multicolumn{2}{|c|}{ Surface. } & \multicolumn{2}{|c|}{ 1-10 fathoms. } & \multicolumn{2}{|c|}{ 11. 20 fathoms. } & 21-30 fathoms. \\
\hline & $\begin{array}{c}\text { Temp. } \\
{ }^{\circ} \mathrm{C} .\end{array}$ & Sal. $\%$ & Temp. ' C. & Sal. $\%$ & Temp. ${ }^{\circ} \mathrm{C}$. & Sal. $\%$ & Temp. ${ }^{\circ}$ C. Sal. $\%$ \\
\hline
\end{tabular}

\begin{tabular}{|c|c|c|c|c|c|c|c|c|c|c|}
\hline Clare Island & W. 67 , & $21.5 . ' 09$ & $11 \cdot 15$ & $34 \cdot 61$ & - & - & $\left\{\begin{array}{l}10 \cdot 69 \\
20 \text { fath. }\end{array}\right.$ & $34 \cdot 64$ & - & - \\
\hline . & W. 69, & 22. 5. ${ }^{\dagger} 09$ & $11 \cdot 35$ & $34 \cdot 60$ & - & - & $\because$ & - & $\left\{\begin{array}{l}10 \cdot 78 \\
24 \text { fath. }\end{array}\right.$ & $34 \cdot 64$ \\
\hline , & W. 70, & , & $11 \cdot 30$ & $34 \cdot 61$ & - & - & $\left\{\begin{array}{l}10 \cdot 50 \\
18 \text { fath. }\end{array}\right.$ & 3467 & - & - \\
\hline , & W. 72 , & , & $11 \cdot 3$ & $34 \cdot 69$ & $\left\{\begin{array}{c}11 \cdot 23 \\
9 \text { fath. }\end{array}\right.$ & $34 \cdot 72$ & - & - & - & - \\
\hline ," & W. 75 & 24. 5. '09 & $11 \cdot 0$ & $34 \cdot 74$ & - & 一 & $\left\{\begin{array}{l}10 \cdot 71 \\
12 \text { fath. }\end{array}\right.$ & $34 \cdot 72$ & $\left\{\begin{array}{l}10.55 \\
25 \text { fath. }\end{array}\right.$ & $34 \cdot 72$ \\
\hline. & W. 81, & 25. 5. ’09 & $11 \cdot 05$ & $34 \cdot 70$ & - & - & - & - & $\left\{\begin{array}{l}10 \cdot 87 \\
25 \text { fath. }\end{array}\right.$ & $34 \cdot 65$ \\
\hline$"$ & W. 82 , & " & $11 \cdot 15$ & $34 \cdot 79$ & - & - & - & - & - & - \\
\hline
\end{tabular}

Clare Island, August, 1911.

\begin{tabular}{|c|c|c|c|c|c|c|c|c|c|c|}
\hline Clare Island & W. 197 , & 18. 8. '11 & $17 \cdot 40$ & $34 \cdot 43$ & - & - & $\left\{\begin{array}{l}15 \cdot 19 \\
18 \text { fath. }\end{array}\right.$ & $34 \cdot 72$ & - & - \\
\hline$"$ & - & ", & $16 \cdot 96$ & $34 \cdot 54$ & $\left\{\begin{array}{l}16 \cdot 12 \\
8 \frac{1}{2} \text { fath. }\end{array}\right.$ & $34 \cdot 56$ & - & - & - & - \\
\hline , & - & $20.8 . " 11$ & $17 \cdot 77$ & $34 \cdot 42$ & - & - & - & - & - & - \\
\hline$"$ & - & | & $17 \cdot 94$ & $34 \cdot 42$ & - & - & - & - & - & - \\
\hline$"$ & - & , & $18 \cdot 05$ & $34 \cdot 31$ & - & - & - & - & - & - \\
\hline , & - & , & $18 \cdot 25$ & $34 \cdot 29$ & - & - & - & - & - & - \\
\hline , & & , & $17 \cdot 92$ & $34 \cdot 29$ & - & - & - & - & - & - \\
\hline , & & 21. 8. '11 & $16 \cdot 92$ & $34 \cdot 31$ & - & - & - & - & -. & - \\
\hline , & W. 205 , & $"$ & $16 \cdot 68$ & $34 \cdot 67$ & - & - & - & - & $\left\{\begin{array}{l}13 \cdot 68 \\
22 \text { fath. }\end{array}\right.$ & - \\
\hline ", & W. 206 , & " & $16 \cdot 6 \pi$ & $34 \cdot 79$ & - & - & - & - & $\left\{\begin{array}{l}14 \cdot 00 \\
24 \text { futh. }\end{array}\right.$ & $34 \cdot 88$ \\
\hline The Bills & W. 207 , & , & $16 \cdot 88$ & - & - & - & - & - & $\left\{\begin{array}{l}13 \cdot 48 \\
25 \text { fath. }\end{array}\right.$ & - \\
\hline , & W. 208, & , & $16 \cdot 91$ & $34 \cdot 78$ & - & - & - & - & $\left\{\begin{array}{l}14 \cdot 01 \\
26 \text { futh. }\end{array}\right.$ & $34 \cdot 97$ \\
\hline Clare Island & W. 210, & ", & $16 \cdot 93$ & $34 \cdot 63$ & - & - & $\left\{\begin{array}{l}14 \cdot 46 \\
20 \text { fath. }\end{array}\right.$ & - & - & - \\
\hline Clew Bay & W. 216, & ", & $17 \cdot 74$ & $34 \cdot 42$ & - & - & - & - & - & - \\
\hline Clare Island & W. 222 , & 22.8 .11 & $16 \cdot 34$ & $34 \cdot 78$ & - & - & $\left\{\begin{array}{l}14 \cdot 94 \\
17 \text { fath. }\end{array}\right.$ & $34 \cdot 79$ & $\left\{\begin{array}{l}13 \cdot 96 \\
24 \text { fath. }\end{array}\right.$ & $34 \cdot 88$ \\
\hline Clew Bay & W. 228, & 23. 8. '11 & $17 \cdot 25$ & $34 \cdot 67$ & - & $\cdots$ & $\therefore-$ & - & - & - \\
\hline$"$ & W. 230 , & $"$ & $16 \cdot 96$ & $34 \cdot 47$ & - & - & - & - & - & - \\
\hline
\end{tabular}


(3) Tides and Currents. - The presence of a good ebb and flow on Clare Island gives a wide intertidal region for shore-collecting. At Westport Quay the rise and fall during spring-tides is about 15 feet, and in April and September 16 feet 6 inches, whilst with neap-tides there is a rise of 12-13 feet. On Clare Island the range is, if anything, greater. Low water at spring-tides is in the middle of the day. In certain spots (i.e. between the islands in Clew Bay and at Darby's Point, Achill Sound) there is a strong current, and the vegetation is of a different character from that found in other parts. Ballacragher Bay, owing to its narrow opening, has but a small tide-not more than 5-6 feet-except during springs.

\section{Phisical Nature of the Coast and Conditions of Exposure.}

Our district presents great diversities in the physical nature of the shore; and in describing the same it will be both convenient and natural to divide it into two areas, viz. (1) Clare Island, and (2) the mainland. Speaking generallor, the island presents an exposed rocky coast, whilst the mainland consists of sheltered ground. In view of the possibility of future work in the neighbourhood, a detailed account of the coast-line is given.

(1) Clare Island.- With the exception of the bay near the harbour and a few sandy patches elsewhere, the whole shore is rocky and cliff-bound. Taking the different parts of the island in order, we find that on the south side the rocks are composed of Silurian slate, which forms flat slopes where the beds lie more or less horizontally, but which is very sharp and rugged where the strata are upturned. Rock-pools, narrow gulleys, and deep channels are frequent, and these were found to be useful, as this part of the shore is as a whole somewhat rough and exposed for general collecting.

The eastern end of the south shore, and from the corner of the bay to Kinnacorra, is composed of Carboniferous sandstone, a formation found to afford excellent collecting-ground. Various degrees of slope and exposure are presented; and towards Kinnacorra there is a fine series of flat rocks and a number of shallow pools. The Carboniferous sandstone is continued to Portlea, a semi-sheltered bay on the north-east side of the island, A boulder-beach surmounts the upper part of this bay; and the rocks below are flat, with a vegetation somewhat different from that found elsewhere. Further north, towards the lighthouse, the slate is again in evidence; and here caves and vertical surfaces, receiving little direct sunlight, are found, and several shade-loving species appear in the open. Though bounded by cliffs, the shore at this point is easily accessible. The fine stretch of cliff on the north-west side of the island is for the most part precipitous, and the narrow strip of shore below is very exposed and difficult of exploration. 
In certain spots it is possible to descend to sea-level, which is found to be strewn with large, irregular blocks and boulders. Little seaweed vegetation, however, occurs. On the cliff, colonies of sea-birds provide the conditions which favour a vigorous growth of Prasiola stipitata.

With regard to exposure, Beetle Head (or Kinatevdilla) and the shore below the north-west cliff are open to the ocean, and feel the full force of the Atlantic rollers. The south side is open to the sea from the south-west, and is also very exposed; but it is not subjected to quite such boisterous conditions as is the north-west side. Owing to the prevalence of southwesterly gales, the exposure on this shore must, however, be very severe. A bend at the eastern end towards the castle affords some protection, as evidenced by the change in the character of the Fucus growth. The sandy bay near the harbour, which faces east, provides the only sheltered shore on the island, and a few sand-loving species are found at the northern corner. Beyond the bay, the stretch of rocks leading to Kinnacorra is subjected to moderate wave-action, and on the whole the conditions are semi exposed. At Alnahaskilla (beyond Kinnacorra) greater exposure is met with, owing to the sea coming in from the north; and for the same reason all points along the north-east side are subjected to rough water, though a certain amount of shelter is found in the intervening bays and inlets. In a general way the north-east shore is decidedly more protected than the south, but less so than Kinnacorra.

(2) The Mrinlund. - When investigating the mainland, it was the usual practice to begin at Roonah Point, at the south-west corner of the Clew Bay, work round to Mulranny on the northem side, and then proceed to Achill Sound and Bellacragher Bay. In describing the ground it will be convenient to follow the same order.

Roonah Quay faces west, and the rocky shore of Silurian slates at the point is subjected to the same exposed conditions as Clare Island. To the south there is a long stretch of boulder-beach, but the presence of rocks in shallow water provides shelter, and there is a certain amount of fairly good collecting-ground. At the point itself, small bays and caves with partial shelter occur. Turning the corner into Clew Bay the exposure rapidly decreases, and between this point and Bartraw there is a series of beaches composed of rocks, boulders, or sand. The surf-loving Nemalion is found as far in as Old Head, where steep rocks and rough water occur for the last time; shallow water then sets in, and there is much sand. When the islands of the bay are reached, the tide recedes for a long distance, and a certain amount of wud begins to appear, but in several spots a luxuriant littoral vegetation exists. 
Many of the islands provide flat beaches of sand and stone with good collecting-ground at low water. At Annagh Island there is a salt-marsh. The Bunowen river at Louisburgh, the stream at Belclare, and the rivers at Westport and Newport give brackish and fresh-water conditions. In the innermost part of the bay there are wide stretches of mud, and the ground is rery poor; with the exception of hasty inspections near Westport and one day at Newport, it was but little explored. The northern side consists largely of sand. At Mulranny there are strips of salt-marsh, also fresh-water and brackish streams. The peninsula of Curraun Achill follows, with a rocky shore of Old Red Sandstone and exposed conditions.

The floor of Clew Bay is everywhere soft, consisting of sand with stones. In spring and early summer there is a rich and luxuriant sub-littoral vegetation, which in shallower parts may be easily studied from a boat, or hauled up by a hand-dredge. Banks of Lithothamnium occur, and there are numerous Zostera beds. Between the outer islands, channels with a swift current, where the bottom is usually stony, are frequent.

Achill Sound, easily reached by train from Mulranny, provides perfect shelter, and yet fully salime conditions. At low water, the Sound becomes dry, exposing a large stretch of sand. The water enters from both the north and south, and at the end of the ebb-tide the parting of the streams will be observed to take place at a point about a quarter of a mile south of Achill Bridge. The regetation is for the most part poor, especially in the summer ; but chanuels provide good ground, and the stones set out by the peasants vield a fine crop of Fucus. Further south (towards Achillbeg) there are swift currents and deeper water, and here a marked increase in the luxuriance of the regetation is noticeable. On the north side of the bridge there is much mud; but the peat banks flooded by the tide offer some interesting types of plant-associations. Bellacragher Bay, a lough-like inlet surrounded by high hills, differs from Achill Sound in possessing deep water, and being less tidal. It is connected with the sea (Blacksod Bay) by a narrow opening at the north-west corner. Several streams descend from the hills: and owing to the water only partly escaping on the ebb, the whole bay must he often more or less lrackish. Some samples taken at the end of the dry summer of 1911 showed, however, almost normal salinity. The littoral region is narrow, and composed of stones or rock. The bottom appears to be rocky, since a vigorous belt of Laminaria is disclosed at low water. 


\section{THE ALGAL VEGETATION.}

\section{(1) Histonical Resume of Previous Work.}

As the present paper forms the first detailed account of the algal assuciations in any area in the British Isles, a general introductory sketch of the subject may be useful.

Kjellmann's papers on the algal regious and formatious of the Murman Sea ('77) and the Skager Rack ('78), form the starting point of the modern method of studying algal communities. Kjellmann divided the vegetation into three "regions," and these he further divided into a number of " formations," which were characterized by a distinctive vegetative facies, due to the predominance of one or more algae.

The main outlines of Kjellmann's classification have been accepted by subsequent writers, though of late years changes in terminology and great elaboration have been noticeable. One of the earliest attempts to apply Kjellmann's methods of study to other countries is contained in a paper by Rattray ('85). The paper, which is a biological and ecological account of the algae of the Firth of Forth, is seldom referred to, though it was apparently the first and, until quite recently, the only one of the kind dealing with an area in the British Isles.

In other countries, however, this branch of ecology has received more attention. The Norwegian algal vegetation has been studied by Hansteen ('92), Gran ('93), Boye ('94-'95), and Kylin ('10), and an account of the Faeröese algae was published by Simmons ('99). The Greenland marine algae have been thoroughly studied by Rosenvinge, who, after giving two systematic accounts, furnished a paper dealing with the algological communities ('99). 'The marine algae of the Baltic have been investigated by Svedelius ('01), who, in his "Osterjöns Hafsalgflora," devotes a chapter to the algal regions and formations found under the peculiar conditions presented in that area. 'The question of defining the algal regions in the non-tidal Baltic had also been dealt with by Reinke ('89). The algae of the Faeröes have been described a second time in the "Botany of the Faeröes"; and Börgesen's treatise "The Algae Vegetation" ('05), which followed his systematic account, is the most important contribution to this branch of algological literature. Kylin, in his algal flora of the west coast of Sweden ("07), deals with associations and other ecological problems at some length. Joubin ('09) described the marine communities at Roscoff, and published an elaborately coloured vegetation-map. The map will be most useful to students working in the locality; but floristic and ecological data are at present somewhat scanty for 
comparative purposes. For the Adriatic, we have Tecket's general account of the algal vegetation of Trieste ('06). The Iceland marine algae are the latest to receive, attention from the ecological standpoint, Jónsson's work ('10) forming a useful addition to his systematic papers which appeared previously. Outside Europe, Sredelius' paper on the periodicity of algae in Ceylon coralreefs ('06), Skottsberg's work in the Antarctic ('06), and Börgesen's accounts of the algal vegetation of the Danish West Indies ('00, '01, '11) are apparently the only papers of the kind which have appeared; but reference should be made to Weber van Bosse ('04), and Schiller ('09), which border on the subject.

Turning to the British Isles, with the exception of Rattray's paper referred to above, no account of the algal communities found on our coasts has appeared, though, as will be seen later, a certain amount of autecology has been done. The numerous and important additions to the British algal flora recorded by Mr. E. M. Holmes and by the late Mr. E. A. L. Batters, have kept our knowledge of the flora well up to date as far as its purely systematic aspect is concerned. Ecological factors, too, were not disregarded, the "habitat" of a species having been always given a prominent place by British writers; so much so, that in a few cases the specific distinction of similar plants has been strongly advocated on the ground of a difference in habitat. Casual reference to the "Fucus-belt," "Coral-banks," and "Laminaria-zone," shows that the more obvious associations were not overlooked.

Pattray ('85) treats at some length of the size of individuals when gathered from different localities and from different levels; he also deals with various problems connected with the distribution and development of the spores. With regard to algal communities, he recognizes the "regions" of Kjellmann, and describes a number of "areas" ("formations" of Kjellmann) characterized by the presence of certain dominant species. His "areas," whether littoral or sub-littoral, are classified alınost entirely with reference to vertical distribution, and there is no attempt to connect them with other conditions such as exposure and desiccation. This results at times in a curious association of names in a given zone, and renders the account somewhat obscure to anyone not familiar with the exact topography of the locality. The paper is, however, full of facts, and will be of great interest and value to the next investigator of the algal vegetation of the Firth of Forth.

In a memoir on Chondrus crispus by Darbishire ('02), the general ecology of the plant is dealt with, and incidentally reference is made to the principal zones of regetation that occur on the shores of the Isle of Man. Two 
interesting ecological papers by Miss S. M. Baker have lately appeared ('09, '10), in which experiments, with a view to determine the causes which bring about zonation, are described; but the general question of algal associations is not touched upon. The ecology of Ulia lactuce has been discussed by me at some length in a report to the Royal Commission un Sewage Disposal (' 11 b). The subject of plant-communities was not in view, but the presence of a distinct mud-formation and an Ulva-association, though not stated in words, was clearly demonstrated. N. H. Johnson has furnished two notes dealing respectively with the mapping and nomenclature of marine vegetation ('11, '12).

An acconnt of the algal associations of a definite area in the British Isles was thus urgently needed, and in the Clare Island investigations this study was given a prominent place. It will be noted that in several of the works referred to, the systematic account was published first, and the ecological treatise appeared later. This order of investigation is essential. The flora must be thoroughly mastered, before the groupings of the species can be accurately studied.

\section{(2) The Areas and the Units of Vegetation.}

\section{A. The Regions.}

Kjellmann's term "region" has been generally adopted by algologists; but the limits of the three vertical divisions included under this term are variously accepted. In the present account they are taken as under:The littoral region extends from the level of the highest marine vegetation to that of low-water mark at neap-tide. The sub-littoral begins from the lower limit of the last-named, and extends down to the limit of seaweed vegetation (i.e. about 25 fathoms). The elittoral region follows, and being devoid of algal vegetation, is of no importance in the present paper.

The reasons for so defining these regions are as follows:- With regard to the upper limit of the littoral region, this, according to Kjellmann, commenced at the highest tide-level; bnt, as several writers have pointed out, the algae on exposed coasts often extend far above the spring-tide limit. A separate region-the supra-littoral-has been suggested by Lorenz. Börgesen, however ('0.5), showed that no hard-and-fast line can be drawn between the vegetation of the supra-littoral and littoral, and for this reason he did not recognize the area as a definite region. In Clare Island the supra-littoral vegetation, though often found, is of less general occurrence than, for instance, in the Faeröes. It is largely due to the presence of spray (a factor 
which is regulated by the exposure and lie of the rocks), but shade and terrestrial moisture are also important. The associations, moreover, found in this area are the same as those in the upper part of the littoral region, and often merely extensions of them. I therefore agree with Börgesen in not regarding it as a separate region.

With regard to the lower limit of the littoral area, on exposed coasts the low-water mark at neap-tide is certainly the natural line of demarkation. At the same time, on a calm day during spring-tides, the Laminaria and Alaria growth may be exposed, and become dry for a short time; but this is obviously exceptional. On sheltered shores the boundary-line is not so clearly marked; and it is difficult to define the beginning of the sublittoral vegetation. In Clew Bay it is particularly perplexing; and the flatter the shore, the less marked is the boundary. As time did not allow of special work on this point, the lower limit of the littoral region has been made uniform with that on exposed coasts-namely, the ebb-mark at neap-tide.

\section{B.-The Formations and Associations.}

A good deal of confusion exists with regard to the terms 'Formation' and 'Association.' Kjellman first introduced the word 'Formation' into algological literature in his paper on the algological communities of the Skagel Pack ('78). He describes an algal formation as a small portion of the whole algal vegetation which is distinguished by a characteristic "Tegetations-Gepräge," adding that in a general way these portions of the vegetation obtain their characteristic stamp through one or more algae that predominate. Most other writers have followed Kjellmann's nomenclature. It is, however, more in accordance with the terminology now generally employed to use the term 'association' for these communities, and to reserve the term 'formation' for communities which occur together in a definite type of habitat. The substitution of the former term for the latter was first put forward by Börgesen ('05), and the name 'formation' was at the same time employed by him for "associations when united together under the same or nearly the same ecological conditions." Examples of Börgesen's formations are the Chlorophyceae, the Fucaceae, and the Laminaria communities of exposed coasts. Kylin ('07) does not follow this nomenclature, but adheres to the term 'formation' with the meaning attached to it by Kjellmann. Jónsson ('10), on the other hand, follows Börgesen.

Börgesen's use of the term 'association' is certainly more correct; but the 
larger communities for' which he employs the name 'formation' appear L') represent groups of associations rather than formations. The term 'formation' if used to correspond with 'salt-marsh formation,' or 'sand-dune formation' of phanerogamic botanists, would be more properly applied to the vegetation covering such areas as exposed rocky coasts, or sheltered muddy shores. These might indeed be callert 'subformations' by some botanists, in which case the whole marine flora would form one formation-the 'salt-water formation.' This, however, is hardly justifiable, and there appears to be no reason why the term 'formation' should not be applied to the principal types of the marine vegetation, as well as to the sanddunes or peat-moors that occur above them.

In the present state of our knowledge it is difficult to define these marine formations; but notwithstanding this I have ventured to use the term for the vegetation covering the principal types of ground that occur on our shores. The formations proposed are three in number:-

1. The rocky-shore formation.

2. The sand and sandy-mud formation.

3. The salt-marsh formation.

All three are represented in the Clare Island area, and in addition two other types are distinguishable, which are dealt with under the heading of-

4. The vegetation of river-mouths.

5. The vegetation of brackish bays.

Each of these five types of vegetation consists of a number of associations, and the latter may frequently show natural groupings. But the associations found vary considerably in different localities, being influenced perhaps most largely by the factor of wave-exposure.

It should be elearly understood that the classification suggested above makes no pretension to be final. It is possible that the rocky-shore formation will have to be divided into other formations; but, judging from general field-work in many parts of the British Isles, this does not appear very probable. The flora certainly varies with the nature of the rock, but the changes consist in the modification or re-arrangement of the associations, rather than in any profound alteration in the plant-formation. The general plant-covering of all rocky shores (including chalk) appears to be of the same type; and for this reason it is here regarded as a simple formation, though further work will doubtless show many differences in detail. 
The distinction between associations and societies is move puzzling Mauy of the small communities that have been described by various writers appear to represent societies (as understood by Tansley and Moss) rather than associations; caution, however, is needed, as definite zonation is discernible in one locality, whilst in others the growth is patchy and discontinuous. For this reason I have adopted a conservative attitude in the present report, and have used the term 'association' instead of replacing it by that of 'society.' In the case of communities described for the first time, when the status was doubtful, a non-committal expression has been used. The whole question of transient societies requires careful working out. Many algae appear periodically, and of these some are short-lived, being conspicuous only for a few weeks, whilst others require six or eight months to complete their life-cycle. It is clear, therefore, that before the status of these communities can be settled, a more complete knowledge of the seasonable range of many species is needed, as well as a more detailed analysis of the vegetation.

\section{3.-The Vegetation of the Area.}

\section{i-The Rocky-shore Formation.}

The rocky-shore formation embraces every form of hard ground, from the exposed rugged slates of Clare Island, to the flat low-lying sandstones of Clew Bay. Great variety in slope and exposure is met with, and also in the surface and hardness of the rock. Speaking generally, the formation is characteristic of open shores. In exposed localities it is the only one to be found. On sheltered shores it is not infrequently poorly developed, or replaced by the sand-and-rock or sandy-mud series. A characteristic feature is the strong basal disk by which the plants are attached, this being true both of exposed and sheltered coasts. Some of the smaller species have, however, other methods of attachment, as explained later. The vegetation of boulder-beaches is included in the formation, and also that of more or less buried rocks and stones, though, in the latter case, the vegetation clearly approaches that of sand-and-rock (pp. 65-67). The pebble-attached association of quiet bays, being characteristic of a soft bottom and not of rock, is placed pro tem. under the sand-formation.

The associations differ markedly according to the amount of exposure, and two series are to be recognized-namely, exposed and sheltered. The littoral and sub-littoral vegetation must also be distinguished; but, except for these, no further sub-division has been attempted. The hardness of the rock, and 
the degree of slupe intluence the vegetation, as rlues also the nature of the rock-surface; but, as stated on p. 16, this produces merely a change in the associations, rather than a fundamental difference in the plant-covering. Boulders may be singled out for notice, since their vegetation is peculiar and well marked. The associations on a boulder-beach are much broken up, and secondary series on the vertical faces of the rock are of general occurrence (see Plate II). The tops of the boulders are usually bare, owing probably to immediate escape of the water, and to extreme desiccation, which prohibit respectively the retention and development of spores. Points such as these continually present themselves when studying the communities; and several are noted in the report; but it is too early to offer generalizations.

A word may be said as to methods of attachment. In addition to the stout disk typical of the formation, three are distinguishable. In the case of simple filamentous species such as Bangia, Urospora, and Ulothrix, each thread is fixed to the rock by the basal cell, with or without the assistance of corticating filaments. Hence the association, which consists of many thousands of minute plants, does not require a rough surface, but occurs also on smooth rocks where other species obtain no footing. It is in reality attached along its whole base. The second type is that of Ccramium acanthonotum, which possesses rhizoids. Such plants cannot grow on smooth rocks, but occur on mussels and barnacles, amongst which they thrust a dense system of rhizoidal filaments. Where Mytilus and Balanus form extensive sheets, these algae are often plentiful. The third type-a soft, spongy diskis supplied by Callithamnion arbuscula. This is intermediate between the two former and the stout cellular disk. The spongy disk is composed of filaments more or less free at the margins, but forming a dense tissue in the centre. Algae possessing this type require a rough surface, and are commonly found on barnacles.

Many transitions exist between the various forms of holdfasts, and the subject, which is of great importance in connexion with the rock-surface, requires detailed study. Epiphytes are adfixed in a number of ways; see Tobler ('06), Menz ('10), and Delf ('12). In spite of the above exceptions, the majority of the algae forming associations on a rocky shore are attached by a stout disk (Fucus, Porphyra, Rhodymenia). 
The following table presents the associations and other communities composing the rocky-shore formation in the Clare Island area:-

A. Exposed coast series.

(a) Littoral Region.

Hildenbraudtia-Verrucaria.

Prasiola.

Enteromorpha intestinalis.

Fucaceae.

Lichina.

Porphyra.

Bangia-Urospora-Ulothrix.

Rhodymenia.

Laurencia-Gigartina.

Callithamnion arbuscula.

Nemalion.

Himanthalia.

Corallina-Lithothamnium.

Pool vegetation.

Cave vegetation.

(b) Sub-littoral region.

Laminaria.

linerusting algae.
B. Sheltered coast series.

(a) Littoral Region.

Hildenbrandtia-Verrucaria.

Fucaceae.

Lichina.

Porphyra.

Laurencia-Gigartina.

Corallina-Lithothamnium.

Corallina-Cladostephus.

Rhodochorton floridulum.

Sand-pool vegetation.

Cave vegetation. (b) Sub-littoral region.

Laminaria.

Encrusting algae.

Fruticulose Lithothamnium.

A. Exposed Coast Series.

(a) Littoral Region.

Hildenbrandtia-Verrucaria Association.

The description of this algal and lichen community is somewhat brief, owing to the difficulty of distinguishing the species in situ, and the labour involved both in collecting and naming material. Hildenbrandtia prototypus and the marine species of Verrucaria are usually taken together as forming one association, and some writers include other plants such as Rivularia atra and Calothrix scopulorum. It is, however, a question whether it would not be advisable to include in the association all the littoral encrusting species that are soft and not calcareous (see note on sheltered form of association, p. 51).

Hildenbrandtia and Verrucaria resemble each other precisely in growthlinlm; and they are often foum rowing together covering an area of several 
square yards. Both possess exceedingly thin encrusting thalli, which are so closely adpressed to the rock, that the latter appear as if coated will paint. In addition to those mentioned above, probably several other species of lichens are present. Of the three plants referred to, $V$. maura forms a band a short distance above the Pelvetia zone, whilst the other two appear below Pelvetia, and descend nearly to the level of low-water. Hildenbrandtia is more susceptible to drying up than $V$. mucosn, and in the Pelvetia and $F$. spiralis zones it occurs under the shade of algae, in damp chinks, or in pools. On ordinary open shores its growth does not occur above this level; but on very exposed coasts when there is spray, it ascends far above high-water line, being found in dark tissures in the rock, or in sull pools that occur on the rugged cliffs, the water of which is often brackish. On the lower part of the shore Hildenbrandtia is not confined to pools and chinks, but is found on bare rocks, and remains quite dry for several hours. In the lowest levels, it is usually replaced by a broad band of Ralfsic clavata, in which patches of Petrocelis cruente are frequent, especially if the rocks are smooth.

Vervucaria mucose grows mostly on half-tide rocks that are fully exposed to light and air; in shady positions or where a covering of algae prevents excessive desiccation, the growth extends to the $F$. spiralis zone; but it rarely, if ever, takes advantage of pools to ascend to a higher level. In this respect it differs from Hildenbrandtia. The plant prefers smooth rocks or boulders, and is seen at its best on the beach north of Portlea, where it covers the upper sides of the boulders from about half-tide level to below the low-water limit of neap-tides. Its growth here is almost pure, and the individual patches are very large, some noted measuring a yard across. The vertical range on the shore varied somewhat in the different localities; but this nay possibly have been due to the presence of more than one species. On only one or two occasions was a Verrucaria-growth noted in a rock-pool. Probably few lichens are so difficult to determine or so little understood as the marine Verrucariae; and it is a source of great satisfaction to learn that Miss M. C. Knowles is working at the problem, and doing so from an ecological as well as from a systematic standpoint. The encrusting algae also are in need of critical study.

The present community is well developed in all parts of the survey-area. It is abundant on smooth slabs and boulders, and is also found on the rough slate and sandstone. It extends to sheltered localities, where, if rocks and boulders are absent, it often occurs on stones and pebbles. A very similar vegetation exists in Sweden, Iceland, and the Faeröes, according to the accounts of Kylin, Jónsson, and Börgesen. 
Prasiola stipitata Association.

This association as it occurs in the Survey area is characteristic of birdcliffs ; but during the winter months it is found to a small extent outside these areas. It is well developed on Caher Island, The Bills, and below the bird colonies near the Signal Tower on Clare Island. The growth is most abundant on the shady side of the clitts, where it ascends to a considerable height above high-water level, and forms the uppermost association of the marine algae. With $P$. stipitcte occurs, in the upper part, a certain amount of $P$. crispa var. marince. The localities referred to are very exposed, and, in rough weather, the clift's are constantly soaked with spray, though Auring calm periods the vegetation must remain dry for some days. The fact that, in June, the small part of the south side of The Bills that was examined showed no trace of Prasiola, suggests that in summer the growth is confined to the more shady situations-a view which is supported by points noted in the following paragraph.

During the winter and spring months, Prasiola is found apart from birds. Wide patches were noted at Koonah and Old Head during the February visit, and in April, 1911, in many spots on Clare Island. The growth is practically pure, but is sometimes mixed with a certain amount of Calothrix and Lyuglya; it occurs on both smooth and rough rocks. In these localities, as on the bird cliffs, Prasiola forms the uppermost algal vegetation, frequently reaching the Lickinc confinis band, but more often forming patches between that zone and Pelvetia. In several spots on the south shore of Clare Island it was present only on rocks sloping landwards, where it was consequently somewhat shaded; but in others it was found on sun-dried rocks and well above the uppermost Pelvetia. These rocks were fully exposed to the surf; and the plants, except during the calmest weather, would be splashed with spray. By July all this vegetation had disappeared; and it was not noted during June of the previous year.

The question of the connexion of Prasiola stipitate with bird-colonies is an interestmg one. 'The preference shown by the fresh-water species, $P$. crispa, for localities soaked with ammoniacal liquid is well known; and its marine relative evidently shares the same avidity for nitrogenous compounds. During a trip to Belfast in connexion with the growth of Ulva in sewage-polluted water, $P$. stipitata was, on the shores of Belfast Lough during April, noted ouly around small drainage outfalls. In Larne Lough also a vigorous crop was always to be found in similar situations. At Ballycastle, Co. Antrim, however, as in Clare Island and Clew Bay, numerous patches of Yrasiola occurred (chicfly in shady spots) where there was no special supply of nitrogenous food. 
'The vegetation described above, taken together' with the Enteromorpha growth, corresponds to Börgesen's "Chlorophyceae Formation." In Clare Island, the Enteromorpha vegetation is entirely distinct from Prasiola, and it occurs only where certain definite conditions are present. In the Faeröes, on the other hand, species of these two algal genera are of general occurrence, and form together a well-marked green belt around the islands. The same is the case in Iceland.

\section{Enteromorpha intestinalis Association.}

As remarked above, the Enteromorpha association of exposed coasts is included by Börgesen in his Chlorophyceae formation. In Clare Island, however, the Enteromorpha growth differs so markedly from Börgesen's community that it is necessary to regard it as a distinct association. In the Faeröes the formation is described as stretching like a green belt along the coast, and composed of four associations which occur in the following sequence:-Prasiola crispa, Rhizoclonium riparium, $\boldsymbol{E}$. intestinalis, and $\boldsymbol{P}$. stipitate. In Clare Island the Enteromorpha association is quite distinct from that of Prasiola, and is found, not as a continuous band, but only where fresh water exudes from the cliffs. This type of green vegetation, though not previously described, is frequently met with in the British Isles. It is not largely developed in the Clare Island district, but is found in its typical form, and is therefore included in the present account.

On crossing from Achill Sound to the island, the association in question strikes the eye as a bright green band near high-water mark, between Kinnacorra and the harluour, and wherever a band of this nature is seen it is a sure sign of the presence of fresh water. Where only a small amount exudes, or the shore falls rapidly, the band is narrow, and a fucaceous or other community follows it at once; but with more water and a gradual slope the association takes the form of wide-spreading bands which run transversely over the rocks with a copious development below of Cyanophyceae and Diatoms. A small amount of Rhizoclonium riparium is, on flat rocks, sometimes intermixed with Enteromorpha; but more often the growth is practically pure, var. cormucopiae being usually plentiful. On vertical rocks and below small waterfalls Rhizoclonium is more abundant and may be dominant. The forms of Enteromorpha present are mostly short forms of L. intestinalis var. yenuina and var. cornucopiae, with the addition occasionally of var. micrococca.

With regard to the bathymetric range of the association, its upper limit varies directly with the position and manner in which the fresh water oozes from the rocks. In some places the growth is completely submerged at high tide, but in vilser spots the upuer part is not even reached by the spray of an 
urdinary spring-tide (e.g., below the lace school on Clare Island). With an alga such as Entcromorphe intestinatis, which is not dependent on salt water, this is only to be expected. By the end of summer much of the growth may be killed through drought, and the lower part of the association then appears as a pure white band of dead tissue.

In rock-pools above high-water mark an Enteromorpha vegetation is found on exposed coasts which may be regarded as merely a pool extension of the community just described. The pools in question usually have a large admisture of rain-water, and during the less sunny parts of the year, they contain a vigorous growth of Enteromorpha, and occasionally Hildenbrandtia and Cladophora sericea.

\section{Fucaceae Association. (Exposed Coasts.)}

The conspicuous growth of the Fucaceae that is found on all rocky shores of the British Isles is well represented in the Survey area. The large size of the plants concerned, and the readiness with which the species can be recognized, render the Fucaceae association one of the most useful and instructive for ecological study. With few other genera can the effect of wave-action on an exposed coast be studied with so much ease, and with few other associations can the differences in composition and in plant-form be so readily traced. On sheltered coasts the study is more difficult. Though familiar in a general way to all British algologists, no definite account of the Fucaceae associations of our islands has been published, and the study of the vegetation as it exists in Co. Mayo was not without value in bringing to light several interesting features.

The composition of the association as it occurs in the British Isles is as follows, the species occurring in the order given from above downwards:-

Pelvetia canaliculata.

Fucus spiralis.

Ascophyllum nodosum (moderate shelter necessary).

Fucus vesiculosus.

F. serratus.

F. ceranoides (admixture of fresh water necessary).

An additional species, $F$. inflatus, was recorded by Börgesen for the Shetland Isles, and Mr. E. M. Holmes has lately received a specimen of this boreal species from Lewis, so possibly it is a regular constituent of the association in the north of Scotland. Besides the ordinary forms and varieties, some very remarkable modifications occasionally occur. (See p. 80.)

Fully exposed Corsts. -Turning to the Fucaceae association of Clare Island, 
we find that in fully exposed localities it is composed of three speoies only, namely-Pelvetia, $F$. spriralis, and $F$. vesiculosus, var. exesiculosus, a precise combination which has not previously been described, unless it be that referred to by Boye ('94-5). Pelvetia forms a narrow zone about 11 -2 feet deep. $F$. spirulis follows with a band only slightly deeper, and composed of fronds seldom more than 6 or 8 inches in length; whilst the lowermost zone of F. vesiculosus, var. cvesiculosus, has a greater bathymetric range, and therefore covers a wider horizontal surface. The fronds are very narrow and the growth short, though, except in the most boisterous spots, it is longer than $F$ spiralis. This type of vegetation is found more or less along the whole south shore of Clare Island, where there is full exposure; and it forms a band covering the entire upper part of the littoral region. The shore is for the most part steep; hence the bands are narrow. With a flatter shore and less exposure, the association spreals out horizontally, and other differences are noticeable as mentioned later.

Of the three species, Pelvetia is perhaps the most susceptible to severe exposure, and $F$. spiralis the least so. In a general way Pelvetia forms a band just above the ordinary high-water level, but it is splashed daily,except in spells of exceptionally calm weather. In very open spots, or where waves break and there is much spray, it ascends much higher. Everywhere it forms a band that is very conspicuous in summer and autumn by its orange-yellow receptacles. Owing to their bathymetric position, the two species of Fuci, unlike Pelvetia, feel the full force of the waves, but it is only in places with the severest exposure that the association is wanting. The attachment to the rock is exceedingly secure, and, though often torn by the waves, none but old and worn-out specimens become detached. Several spots were noted where $F$. spiralis only occurred, and it appeared that the exposure was too great for $E$. resiculosus. When fruit is absent it is difficult to distinguish the two species; but in fertile specimens the short, rounded, hermaphrodite fruits of $F$. spiralis, and the narrow, pointed, unisexual receptacles of $F$. vesiculosus separate them at once. On exposed coasts the former plant fruits from spring to late autumn, the latter in winter, spring, and early summer.

Moderately exposed Cousts. - On passing to less exposed rocks or to bays where there is a measure of shelter, a difference in form and in composition is at once apparent. Pelvetia remains the same, but takes a somewhat lower level. F. spiralis becomes longer and the fronds wider, but still retains its typical spiralis form. F. vesiculosus is also larger, and often possesses a few bladders, the size of the frond and the number of bladders increasing with the amount of shelter. A fourth species, $F$. serratus, now enters the association. This begins in the lower part of the $F$. vesiculosus zone (slightly above 
Himanthalia), and forms a broad band extending down to the Laminaria level. It appears to enjoy moderate wave-action, but requires flat rocks, and disappears at once where the rocks are steep or the exposure too great. This form of fucaceous growth occurs typically on the slopes near Kinnacorra, near the Castle, and at several spots on the south shore,

With greater shelter further differences are evident. Pelvetia and $F$. serratus remain as before, but $F$. spiralis broadens ont into var. platycarpus and $F$. resiculosus develops more vesicles, the length of both species increasing and assuming the heavy bulky growth characteristic of sheltered coasts. The horizontal distribution also of all the species tends to increase, owing to the shore being usually flatter. Such growth occurs in several bays on the island, and is common in more open parts of Clew Bay. Ascophyllum nodosum requires considerable shelter; and in Clare Island it is present in one spot only, namely Ooghbeg on the south shore. The shore here is rather flat, and the force of the waves is broken by the presence of blocks and boulders. At Portlea (parts of which might appear to be equally sheltered) Ascophyllum is absent, but the presence of a vigorous Himanthalia vegetation indicates greater exposure than might be supposed. For further notes on this species see p. 55 .

Eniphytes. - The typical epiphytes of the exposed Fucus association are as follows, and in the most exposed spots these are practically all that occur:-

Ulothrix pseudotlacea (in spring).

Enteromorpha compressa.

Ectocarpus luteolus.
Elachista fucicola.

Porphyra umbilicalis.

Where the conditions are less hoisterous (e.g. at Kinnacorra) a number of other species occur in addition, for example-

Ectocarpus tomentosus.

E. fasciculatus.

Porphyra leucosticta (in spring).

Rhodymenia palmata.
Polysiphonia fastigiata (on F. spiralis). Ceramium rubium.

C. Boergesenii.

Subretution. - This, though always better developed in the lower than in the upper levels, is largely dependent on the denseness of the Fucus growth, i.e. on the amount of room and light available. When conditions are favourable, the first four of the following communities are usually represented, and the last three are occasionally present in addition:-

Hildenbrandtia-Verrucaria Association.

Porphyra umbilicalis

Laurencia pinnatifida

Corallina spp. Society
Lichina pygmaea Association.

Rhodymenia palmata ,"

Lithothamnium Lenormandi Socioty. 
In the low littoral region, if the $F$. semulus vegetation is not dense, a very large number of species occur, the shelter and shade being highly suitable for :-

Dictyota dichotoma.

Chylocladia ovalis.

C. articulata.

Delesseria alata.

Nitophyllum laceratum.
Polysiphonia fruticulosa.

P. thuyoides.

Plumaria elegans.

Lithothamnion polymorphum.

Sporelings, many spp.

Comparison with other Countries. - In a general way the Fucaceae association described above represents that of the whole of the British Isles. It agrees well with that observed on the south and east of England, and though the Fucaceae of the British Isles have never been specially investigated from the present point of view, it is not likely that any startling departures from the Clare Island type will be met with. The greatest variation may be expected on the north of Scotland. The vegetation described for the Norwegian coast is similar, agreeing floristically, but differing in minor points. With more thorough investigation some of the latter will probably disappear. In west Sweden, Pelvetia is absent, and Kylin makes no reference to $F$. spiralis on exposed coasts. He notes the presence of the form $F$. Areschougii on moderately open shores, and it would be remarkable if the short exposed form, so addicted to boisterous localities elsewhere, were absent. A belt of an evesiculate variety of $F$. resiculosus is well developed, but from specimens sent by Dr. Kylin, it is clear that his form (compressus racemosus, Kjellman) is different from that which occurs on Clare Island. The Faeröese Fucus vegetation differ's in several respects from the Irish. In the first place, $\boldsymbol{H}$. serratus is absent, $F$. inflatus taking its place; $F$. spiralis is not found with extreme shelter, and $F$. vesiculosus disappears entirely with exposure; lastly, Pelvetia is absent from exposed coasts. The last two points were specially investigated by Dr. Börgesen during his visit to Clare Island; and he agreed that both species flourish in Ireland with very much more exposure than in the Faeröes. The Fucus vegetation of Iceland is similar to that of the lastnamed, in that it possesses a vigorous growth of $F$. inflatus, though $F$. serratus is present in addition. From the brief account given by Joubin ('09), the Fucaceae vegetation at Roscoff appears to agree in the main with that of the British Isles.

The Lichina communities.

Though a lichen and not an alga, Lichina pygmaea is always found between the tide-marks, and forms so essential a part of the marine vegetation that it 
deserves mention in the present report. The second species, $L$. confinis, is scarcely littoral, being confined to rocks just above high-water line, but its growth may be suitably described together with that of L. pygmaea. The zones formed by these two species at times approach one another, but they never overlap. Both occur on sheltered as well as on exposed coasts, though for L. pygmaed rocks or boulders are essential. With the exception of Joubin ('09), algologists have not dealt with this vegetation, though Nylander, as long ago as 1861, drew attention to the belts of Lichina on the sea-shore.

(a). L. pygmaen, the larger and more conspicuous species, forms circular patches which vary from a few inches to a foot in diameter. It usually commences immediately below Pelvetia, and extends downwards through the $F$. spiralis belt to $F$. vesiculosus, or to within a few feet of low-water. In certain localities it extends well up into the Pelvetia band; but it never occurs above it. The maximum development usually takes place in the upper part of the zone, where the plant often forms a very conspicuous black band on the vertical faces of rocks or boulders capped with $F$. spiralis. It undoubtedly favours sloping or vertical surfaces; but it also occurs on those that are horizontal. Though frequent on smooth boulders, it prefers rough or eroded rocks, and is abundant on baruacles. Unlike $L$. confinis, the present species can only stand a certain amount of drying. In the lower part of the association it occurs fully open to the sun; but in the uppermost levels it is usually found in chinks and pockets which retain moisture, or on rocks with a shady aspect. In calm weather, during neap-tides, the Pelvetia zone may be left entirely dry for several consecutive days; and any growth of $L$. pygmaed that reaches this level is occasionally subjected to like conditions.

On the exposed and semi-exposed shores of Clare Island and the mainland L. pygmuer is abundant, but where the exposure is excessive it does not appear to flourish. On the large blocks and boulders to the north of Portlea it is one of the few macroscopic plants which form a definite association; and in such localities, where Fuci are absent, the lichens form a useful means of determining tidal levels. A very luxuriant vegetation of Verrucaria spp. covers the boulders of this beach almost from top to bottom (p. 20).

During the summer (July-Sept.), a fine growth of Rivularia bullata is frequently found epiphytically on L. pygmaea. In 1911 it was unusually abundant, being noted in August in all the exposed parts of the mainland and Clare Island. $R$. bullatı is not confined to the Lichina patches, but also occurs on bare rock. It sets in about half-tide level, and continues to low-water mark.

(1), The second species, L. confinis, has fronds barely $3 \mathrm{~mm}$. long, and the individual patches are $2-4 \mathrm{~cm}$. in dianeter; being black in colour it is very

\section{2}


inconspicuous on the dark slaty rocks of Clare Island. It usually occurs a short distance above Pelvetia, and extends up the cliff's on the south shore to a height of 12-15 feet. In this position it is frequently drenched with spray, though in summer it may be dry, except for rain, for weeks together. With less exposure its vertical range is restricted. On the gentle slopes at Kinnacorra it is only 3-4 feet ahove Pelvetia; whilst on the flat shores of Clew Bay and Achill Sound it hardly exceeds the neap-tide level, and is regularly covered during the highest tides. This occasional Hooding by springtides in sheltered localities obviously takes the place of the soaking by spray on open coasts. In Clew Bay and other places where rocks and boulders are absent, the plant often occurs on Hat stones, and may even be traced as an irregular band running along the shore. In Roundstone Bay the three plants, $L$. confinis, $P$. canaliculata, and $L$. pygmaea were noter on large slabs, forming luxuriant and well-marked zones, each species following the other as a band, 1-2 feet deep.

The Lichina vegetation at Roscoff described by Joubin ('09) is evidently very similar to that found in Irelaud. Both species are present, and the plants show a preference for exposed situations.

\section{Porphyra umbilicalis Association.}

Porphyra is one of those algae which occur as a definite association on both exposed and sheltered shores. The form assumed by the plant is very distinct in the two situations; and it is curious that it has not been seen as an association in localities offering intermediate conditions, although its occurrence in small quantity is common enough. Another feature which gives interest to the exposed Porphyra community is the diversity of its bathymetric range in different countries, and even in different spots in the same locality. For instance, in Clare Island the upper limit of the Porphyra belt is almost always below the Pelvetia zone, whereas in the Faeröes the greater part is normally above that belt, and on exposed shores it may occur as much as 40-50 feet above high-water line. Doubtless surf and spray are largely responsible for its presence in such positions, just as they are seen to be directly responsible for minor variations on Clare Island. But this alone does not account for all the differences that have been noted, and further study is needed.

On most parts of Clare Island a certain amount of Porphyra vegetation is present; in some it is extensive and forms broad or narrow bands; in others it is limited, and occurs only as small patches between other communities. It prefers rocks of a moderate or rather steep slope, but is also 
found on flat rocks, and rarely on the perpendicular faces. The rock-surface may be rugged or smooth, and a very favourite substratum is that of mussels. In all cases the rocks are exposed; and often the most vigorous patches are those where the waves strike with great force. The normal position of Porphyra is in the upper part of the littoral region, where it occurs as a band a short distance below Pelvetia. In some cases the band is quite narrow, as is shuwn in Plate I, where it occurs between Pelvetia and $F$. vesiculosus, taking the place of Fucus spiralis; in others it is mixed with $F$. spiralis, and runs down through the wider belt of $F$. vesiculosus that follows. Porphyra also occurs where the Fucaceae are absent, and is here commonly mingled with Bangia or Cerumium acanthonotum. At Kinnacorra it is found on smooth sloping rucks devoid of regetation, aud forms a fairly wide band from a short distance below high-water mark down to about half-tide, at which level Bangia takes its place. In this position, being quite unprotected from the sun, it becomes very dry and disappears during summer.

A very distinct aspect is acquired by the association during winter, owing to the presence of an abuntant growth of var. lincaris. This plant, though often regarded as a distinct species, represents sporelings of $P$. "mbilicalis, which at that seasou are elongated and tapering. The growth appears first in October, and develops rapidly during the winter, frequently covering boulders and smooth rocks over extensive areas. It is usually quite distinct from the normal Porphyra association, and forms a band above it. In March the effect of drying winds and increased sunlight is felt, and much of the growth dies. By April var. linearis has lisappeared, except in lower and shaded places.

With regard to the supra-littoral growth, the contrast between Clare Island and the Faeröes is most marked. In a few spots Porphyra was noted as extending into the Pelvetia band on Clare Island; and at Alnahaskilla it was found at the highest tide-level on the north side of steep bare rocks, a sample of the kind of growth that takes place on a much larger scale on the Faeröes. Below the big cliff on the north side of the island, where the shore is steep and the rocks fully open to the Atlantic, Porphyra was one of the few algae that were noted in the littoral zone. But even here, with shade and continual spray, there was no supra-littoral growth comparable to that described by Börgesen. Its growth probably exceeded the limit of high-water level (which, owing to the constant swell, is not easy to determine), but not to any remarkable extent. In the Faeröes, on the other hand, even in sheltered localities, the lowest limit is at high-water mark, and in exposed situations it is not found till far above that level.

Kjellnann and uther icandinavian algrolugists have regarded the Porphyrd 
community as a winter vegetation; and Börgesen states that, though in the Faeröes it is developed all the year round, it is in more southern countries characteristic of winter. On Clare Island this is hardly the case. The Porphyra association is in fine condition in July and August, and abundant even on the south shore (vide Plate I). It is, however, more widely spread in winter, owing partly to the presence of a band of var. linearis; but the association in the Clare Island neighbourhood certainly occurs throughout the year. Börgesen also remarks that he did not observe the Purphyra vegetation at North Berwick (Scotland) in July, 1909, but Dr. A. A. Lawson informs me that at St. Andrews (about seventeen miles further north) it was plentifnl in July and August, 1910; though in the hot dry summer of 1911 it was much less conspicuous. In the south of England it is a winter and spring vegetation, though in July, 1911, the Porphyra belt was still discernible on exposed rocks at Portland Bill. 'The exposed Porphyra association is also recorded from Iceland (where it closely resembles that of the Faeröes), west Sweden (Kjellmann, '78, Kylin, '07), and Norway (Kylin, '10).

To sum up, the Porphyra vegetation of the exposed coasts of Clare Island forms a belt in the littoral zone, at a very much lower level than it does $\mathrm{nI}$ the Faeröes, and does not, ever in shady and very exposed localities, grow far above the high-water line. In contrast to the south of England, Sweden, and Denmark, but in agreement with that described for Norway and the Faeröes, it exists through the entire year. The form of the plant on exposed coasts is entirely different from that found in sheltered localities.

\section{Bangia-Urospora-Ulothrix Association.}

The most striking feature of this community is its sporadic appearance. During the first two years of the Survey scarcely a thread of Bangia or Urospora was found; but during the spring of 1911 a remarkably fine and widespread development of the typical Bangia-Urospora-Ulothrix association occurred on Clare Island and on the exposed parts of the mainland. This vegetation was probably at its best during the time of the April visit; by August it had entirely vanished. In the Faeröes it appears to be more or less permanent; but, as shown below, its sporadic appearance is known in other countries, and it may even be absent for several years in succession over a wide stretch of coast-line (vide Börgesen, 05, p. 720). For this reason the appearance of well-marked belts of Bangia and Urospora during the last year of the Survey was particularly gratifying.

The community in question occurs on exposed and moderately exposed rocks, especially where the surface is smooth and where other algae do not ootain a footing. In bathymetric range the association as a whole corresponds 
to that of Porphyra, extending from below the Pelvetia zone to within a few feet of low water. Its composition is as follows :-

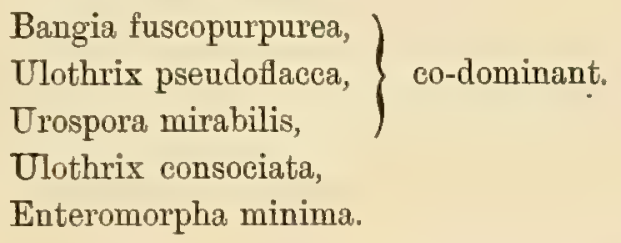

As a rule all the species, except $E$. minima, which is local, occur together, though each forms a separate patch or narrow strip within the association. Occasionally, however, the species occur separately; and a pure growth of Bangia or Urospora may cover a wide area. In a few cases the growth may be thoroughly mixed. -

An effort was made, when the full series was present, to determine the rertical sequence of the species; but this was unsuccessful in so far as obtaining a constancy in succession was concerned. The necessity of microscopic examination made the determination in the field difficult, and the work required more time than was available. As a general rule, however, where the association is typically developed, Bangia appears to have a wider vertical distribution than the other species, as it is often both the first to appear and last to leave on passing from top to bottom of the area. But occasionally a Ulothrix growth is found at a very high level in sheltered localities where Bangia is absent.

The occurrence of the Bangia-Urospora association on smooth rocks and boulders where other vegetation is absent is explained by the exceedingly fine unbranched filaments of the plants, reducing to a minimum the strain on the basal attachment. At the same time each filament is separately fixed to the rock, so that the association may be said to be attached along its whole base.

The most usual extraneous species is Porphyra umbilicalis, small specimens of which frequently occur in the upper levels; and it is into the Porphyra association that the present community most frequently merges. Bangia, which is less restricted than Ulothrix or Urospora, also occurs on barnacles, where it enters into competition with Ceramium acanthonotum.

The total absence of Bangia in some years has been referced to by Börgesen for Norway ('05, p. 720), and Rosenvinge for Denmark ('09). The latter, who has studied the Bangiales of Denmark in detail, writes as follows concerning B. fuscopurpurea:-

"The most dangerous condition for the Bangia vegetation is a fairly long period of easterly winds so light that this vegetation is not reached by the 
waves, especially when whe weather at the time is bright and dry. Its occurrence is therefore very different, not only at various seasons, but in different years. In winter it is very abundant: but the critical period of the spring will every year kill a greater part of it; and on the duration and intensity of this period depends to what degree that will take place. In summer, for example, it occurs at Frederikshavn in some years only in small quantity, while in others it forms extensive growths-as in the beginning of August, 1902 " (1.c., p. 58).

With regard to Clare Island, drying winds during a critical period of the life-history no doubt largely influence the growth of the plants. The association may occur annually as winter vegetation, and it may possibly have been present in the early spring of 1910 ; but if this was the case, it had completely disappeared by June, and was certainly absent in April, 1909.

Comparison with other Countries.-An association corresponding to that described has been noted in many countries. It is present in Norway, Sweden, Greenland, Iceland, and the Faeröes, having been dealt with by Kylin, Rosenvinge, Jónsson, and Börgesen respectively; and, as already shown, it occurs in Denmark. The belt in these countries, as would be expected, is found at a higher level than in Clare Island. It reaches, or extends above, the high-water line in each case; and in the exposed part of the Faeröes it occurs as much as 30 feet above this level. In Greenland the association differs floristically, and is termed by Rosenvinge the Monostrome grocnlandicum association, after the dominant species. In the Baltic (Gotland) Svedelius has described a similar vegetation, consisting entirely of Urospora penicilliformis.

Rhodymenia Association.

An association of Rhodymenia similar to that deseribed by Börgesen, and noted by him as being widely spread on the Faeröes, occurs in our district, though only to a limited extent. Börgesen stated that he had found no reference to such an association, but that he expected it to be common in the North Atlantic. In the Clare Island area it is but feebly developed; but at Dog's Bay, near Roundstone, a very extensive growth was observed, showing that the association exists on some parts of the west of Ireland, as indeed was already known. On the island, patches of Rhodymenia occur in several spots between Yortlea and the lighthouse, and on the mainland at Roonah and at Old Head.

Judging by the localities in which the plant was found, Rhodymenia prefers a northern aspect, which would account for the complete absence of its growth, as an association, on the south shore of Clare Island. At Old 
Heul il is found on Hat, sloping, or vertical, semi-exposed rucks, which face north or north-east. At Portlea it affects similar situations, but shows-a decided preference for vertical rocks (these being at the sametime the more shaded). The plants are attached by a strong basal disk, and are usually found on mussels, but they occur also on limpets and bare rock. The vertical area corered by the alga is rather extensive, reaching at times from the bottom of the $F$. spiralis zone down to about low-water mark, but more often forming a band below the upper Porphyra. It is frequently interrupted by patches of other regetation. At Old Head, Fucus vesiculosus, var. cvesiculosus is the ehief intruder; but portions of the Porphyra and Callithamnion arbuscula associations above, and the Nemalion vegetation below, are also interspersed amongst it. A modified form of the association occurs on boulder-beaches, the plant hanging in profusion from the lowel part of boulders surmounted by Himanthalia (Plate II).

The form of the alga when growing as an association on exposed coasts is very distinct. Short and tufted, not more than 3 to 4 inches long, it consists - of narrow or rounded fronds, with a number of small lateral proliferations. 'Though namow, it is very distinct from var. samiense, which is thinner and paler in colour, and resembles Cracilaria multipartitu in form. With increased shelter the plant becomes larger, till at length the pool-form, with fronds a foot or more in length, is reached. 'The islanders distinguish the larger and small forms as Dillisk and ('rannogh respectively, and always associate the latter with the presence of "small shells"-i.e., mussels (see Economic Section).

Börgesen remarks that the Rhodymenia association prefers places where fresh water oozes from the rocks. This is not the case on Clare Island. As a pool or streamlet plant, Rhodymenia enjoys an admixture of fresh water; but when growing as abore described, it was always found in a purely marine habitat.

\section{Laurencia-Gigartina Association.}

Near the low-water line on exposed coasts there often exists a dense carpet composed of the two red algae,-Laurencia pinnatifida and Gigartina mamillosr. Gigartina occlipies the lower part and goes down into the sublittoral region, whilst Laurencia extends more or less in an upward direction. The band formed by the latter is often conspicuous, so much so that it was at first regarded as a distinct association. Further examination at springtides showed that it was frequently connected with a zone of Gigartina, and that in the more exposed places the latter species was dominant. It gradually became evident that their relative abundance was largely a matter of exposure and slope, and that these two species of similar habit could be 
naturally regarded as forming a single belt. In a general way Laurencia prefers a certain amount of shelter, and thrives on sloping or flat rocks, whereas Gigartina enjoys the roughest water and steep surfaces. On comparing this plant-community with those of other countries, it was found that the joint belts formed by the two species in Clare Island corresponded to Börgesen's Gigartina association in the Faeröes-a conclusion which was confirmed by him during his visit. It was thought best, therefore, to connect the Irish type of vegetation with the Faeröese, and the name Laurencia-Gigartina association has been given. In the Faeröes Laurencia is very rare, being found only in pools.

The Gigartina band may be dealt with first. On exposed coasts it is barely uncovered during neap-tides, but with spring-tides a distimct belt reaching down to the Alaria and $L$. digitato zone is revealed. It is frequently accompanied by a certain amount of the narrow form of Chondrus crispus. Well seen on vertical rocks, where it forms a band 2 feet deep, it also occurs on flat and sloping surfaces, here usually as an undergrowth to Himanthalia. On the open coasts it is often accompanied by the following algae, all of which are known to enjoy the turbulent conditions of low-water mark:-

Scytosiphon lomentarius.

Rhizoclonium implexum.

Chylocladia ovalis.

Lomentaria clavellosa.
Plocamium coccineum.

Polysiphonia thuyoides.

P. Brodiaei.

Corallina squamata.

The Gigartina belt occurs also on the more sheltered ground at Portlea. It first appears well up in the Laurencia band; but as the lower levels of the littoral region are reached, it increases greatly in quantity, till finally it occurs as a pure growth covering comparatively large areas. At Kinnacorra, on the other hand, where there are varying degrees of exposure, the Gigartina vegetation is practically absent.

Passing now to Laurencia, we find this is more conspicuous on account of its truly littoral habit. It begins shortly below the half-tide level, and runs down into the Himanthalia association. It is common on moderately exposed shores, and appears to prefer clean, gently sloping rocks where sand is absent. Under these conditions Laurencia may exist as a pure growth 2 or 3 yards wide, but where the shore is flat it extends over a much wider area, being then mixed with other species. When sand is present it gradually gives place to Rhodochorton floridulum.

In its lower levels the Laurencia belt forms an undergrowth to Himanthalia, and on sheltered shores occurs in a similar manner beneath $F$. serratus. It is found at times under $F$. vesiculosus, and thus runs upwards considerably 
higher than on bare rocks. If the shade be not too dense, its growth is quite as luxuriant as when fully exposed to light and air.

Another species, L. hybrida, is a characteristic element in the upper part of the association. This plant is more restricted in its range, and appears to be more sensitive to desiccation. On a flat shore it reaches its maximum development somewhere about the middle of the $L$. pinnatifida band, where it is at times eo-dominant. In the lowest parts it is practically absent; and in the upper it is found only in the damper positions. On very exposed shores L. hybrida is scarce (see p. 136).

L. pimatifida reaches its maximum development about April or May; and at this season sloping rocks are carpeted with a growth 4 to 6 inches high. After May many of the larger fronds disappear, and the association as a whole becomes inconspicuous. There remain, however, numerous small shoots, which are continually augmented during the summer, the plant being apparently perennial. L. hybrida, on the other hand, is an annual. Young sporelings 1 to $2 \mathrm{~mm}$. long are discernible in September; they develop during winter, fruit in spring, and disappear in May.

Very marked colour-changes due to illumination are shown by L. pinnatifida, and to a less extent by Gigartina. The normal colour of the former is a deep purplish red; but during summer the growth in sunny situations is pale yellow green. This gradually gives place to purplish green in autumn, which becomes redder as the days shorten. The production of antheridia by Laurencia in March and April gives the plants a golden hue, owing mainly to the yellow substance found in the antheridial cavities. As a large number of male plants are often found together, sheets of bright yellow fronds are frequent.

\section{Callithamnion arbuscula Association.}

'The plant-community formed either by Callithamnion arbuscula, or Ceramium acanthonotum, or a mixture of both, has been described by several writers under various names. Callithamnion is the more conspicuous plant, and most writers have dealt largely with this species; Ceraminm acanthonotum is, however, an equally important element. Clare Island is peculiar in possessing in addition a small quantity of the southern Callithamnion granulatum.

The association is well developed on many parts of the island and exposed mainland. The relative amount of the two species varied during the different seasons-a fact which probably explains discrepancies in accounts of the same area by different writers. In July, 1910, Ceramium acanthonotum was the dominant species on Clare Island, whereas in August, 1911, 
Callithamnion arbuscula was more abundant. Apart from these seasonal variations, Ceramium is found chiefly on bare slopes with much or molerate exposure; sometimes it occurs pure, forming a dense carpet several yards square, but more often it is mixed and interrupted. Callithamnion prefers the more boisterous positions, and is especially luxuriant on steep or vertical rocks.

The belt formed by the association is at the same level as the lower part of the Bangia and Porphyra associations, or slightly ligher than the Nemalion and Corallina communities. It usually begins just below $F$. spiralis, and extends to within a few feet of low-water mark. Callithamnion often appears a short distance above Ceramium, but for the most part the two species occupy the same level. Where fresh-water streams exist, Ceramium not infrequently ascends the shore, and may reach as high as Pelvetia. C. arbuscula, on the other hand, does not thrive in fresh water.

Unlike the Bangia-Urospora association, the present plant-conmunity is most frequent on rough surfaces offering a good foothold. Ceramium, which forms a spreading growth, usually occurs on mussels and Corallina, amongst which it pushes a mass of rhizoids; but it also grows epiphytically on the Callithamnion. The latter, on the contrary, has a scattered habit, each plant pussessing a single stem, which is thick and spongy. It is most frequently attached to limpets, mussels, or the rock between them; only rarely is it found on other algae. Although both species occupy a fairly high level, owing to the retention of water by their spongy thalli neither becomes dry when the tide is out.

The associations into which the Callithamnion arbuscula vegetation most frequently merges are those of Bangia, Nemalion, Corallina; and in addition to algae derived from these sources the following species frequently occur scattered in it:-

Rhizoclonium tortuosum.

Enteromorpha compressa.

Scytosiphon lomentarius.

Petrospongium Berkeleyi.
Polysiphonia macrocarpa.

P. Brodiaei.

P. thuyoides.

Comparison with other Localities.-In the British Isles Börgesen has noted the community in Shetland, and I have observed it at Whitby (Yorks). On the south coast of England, where $C$. arbuscula is absent, the association is represented by a belt composed entirely of $C$. granulatum (=C. spongiosum, Harv.). This has been noted at Swanage and Portland, and is doubtless common. Ceramium acanthonotum, though known on the south coast, dues not enter into the Callithamnion association in either of these localitics. 
It is interesting to note that, though C.arburscule was the essential species in Clare Island, specimens of the southern $C$. granulatum were scattered here and there amongst it. The latter agreed in form with the Dorset specimens, being short, very densely branched, and of a peculiar pale colour-a feature which gives the clue to its presence (see p. 142).

Hansteen, Boye, and $\mathbf{K} y$ lin have each dealt with a vegetation on the west coast of Norway that is probably very similar to that here described, thuugh it is Callithamnion that has mostly attracted attention. Kleen also records both algze from Nordland. In the Faeröes, Simons refers to a "C. acanthonotum formation," not observing the presence of C. arbuscula, whilst Börgesen, exploring the coast more thoroughly, found the latter abundantly in exposed places, and adopted the older term. Both species are found in Iceland, though Jónsson does not allude to them as forming an association.

Some remarks by Harvey with reference to this vegetation may be quoted here. He observes with regard to $C$. arbuscula that "it delights in the most exposed rocks and the roughest water, and very commonly grows on the shells of Mytilus rugosus" (Phyc. Brit., pl. 274); and concerning C. spongiosum, he writes, "It is curious that it appears to occupy the place of $C$. arbuscula on shores where the latter is not found, these plants never growing together, though both affect similar situations on different shores" (l. c., pl. 125). As shown above, Harvey's statement as to position and habitat of the species holds good for many countries, though the Clare Island work proves that the two species may occasionally occur together.

\section{Nemalion Association.}

The present vegetation, described by Kjellmann in 1875, was one of the first algal associations to be recognized. It differs from many others in being a purely summer growth, and might therefore be more suitably regarded as a plant-society. The Nemalion belt occurs in the lower half of the littoral region-that part of the shore which is crowded with a succession of algae, and in which many transient societies are recognisable. Nemalion prefers bare rocks, and usually develops in spots devoid of other vegetation. It would probably find a place as a subdivision of Börgesen's "Corallina formation"; but in the present state of our knowledge it appears advisable to follow previous writers rather than introduce doubtful alterations.

The Nernalion growth is first noticeable early in. June, reaches its maximum in Augnst ur Septemlier, and disappears in October. The association in Clare 
Island (as in S. Englaud) is composed of two species- $N$. multificum, and the stouter unbranched $N$. elminthoides Batters $(=N \text {. lubricum J. Ag. })^{1}{ }$ The zone formed is 5 to 6 feet deep, and extends from about half-tide level to the ordinary low-water mark. Its luxuriance varies considerably in different localities. In some, a vigorous growth is present in the upper part of the zone, whilst in others the algae are better developed near low-water mark. $N$. elminthoides is usually confined to the upper portion, and lasts later in the season than N. multifida. The plants are attached to bare rock, or limpets, and occasionally to mussels. They prefer sloping surfaces, fully exposed to waves and surf.

The Nemalion association is found in the band of Lithophyllum incrustans ; lut it prefers bare rock devoid of other vegetation. Where mussels occur, it is usually replaced by the association of Cercomium acanthonotum, or Rhodymenia. Amongst it are scattered individuals of Scytosiphon lomentarius, Enteromorpha compressa, Rhizoclonium implexum, and Polysiphonic Brodiaei, the last-named being confined to the lowest levels. On Clare Island the association is of frequent occurrence; and in Clew Bay it occurs on exposed points, such as Old Head. A similar type of growth has been described by Kjellmann ('78), and Kylin ('07), for west Sweden; by Gran ('93) for Norway it would appear also to be widespread in Denmark (vide Rosenvinge, '09). In the south of England the community is frequently met with, having been noted by me on the coasts of Dorset, Devon, and Cornwall.

\section{Himanthalia Association.}

This familiar association, which is well developed on Clare Island, is characteristic of moderately exposed shores. It forms a belt in the lowest part of the littoral region; but the extent of its horizontal range varies with the amount of slope and the nature of the coast. On steep and vertical rocks it is absent, or exists as a narrow band, 1 foot deep. On a shore of moderate slope the band is wider, and extends from the Laminaria zone to 2 or 3 feet above low-water mark; whilst on flat shores, especially where there is a dense sub-vegetation, it covers a wide area. With partial shelter, Himanthalia descends some distance into the sub-littoral region, and occurs mixed with Cystoseiva ericoides and species of Laminaria; but apart from the extension both in an upward and downward direction, its normal position

1 This plant, clearly figured by Velley, is usually regarded as a distinct species; but as seen in Clare Island and in the South of England, it is diffeult to separate from $N$. multifidum. 
on a sloping shore is between the Latrencu pinnatifidu belt and the Laminaria association.

In the form of a narrow band, the Himanthalia vegetation is seen on the south shore of Clare Island in spots where the rocks are steep, and there is full exposure to the waves; as a wider zone, it shows well on rocks which form large sloping slabs, as at Kinnacorra. At Portlea a more extensive growth is met with. The shore here is flat, but there is a moderate amount of rough water and surf. A dense undergrowth of Laurencia pinnetifida and other algae corers the lower part of the littoral region, and on this the Himanthalia lies as a thin covering. The belt, however, is not so deep as it appears; for, although during spring-tides it is left dry for three or four hours, during neap-tides the time of exposure and the amount uncovered are small. The undergrowth conserves moisture, and enables the alga to ascend to a higher level than otherwise. Portlea also affords an example of another type of growth, viz., that on blocks and boulders. In this case Himanthalia is attached to the upper parts of the boulders; but the strap-like fructifications hang down over the sides (see Pl. II). Here again the alga may ascend above its normal limit owing to the shade between the boulders.

Börgesen remarks that, according to Boye, Himanthalia avoids localities directly exposed to the surf, which is in contrast to its habit in the Faeröes. In the British Isles it is certainly a surf-loving species; and in Clare Island it occurs along the south shore, and also on such exposed points as Alnahaskilla. At Ooghbeg, the one spot on Clare Island where Ascophyllum exists, Himanthalia is found where the waves break at low-water; but as a rule, if there is sufficient shelter for Ascophyllum, Himanthalia is absent. As noted by Börgesen, the present alga cannot stand desiccation; and though odd plants are seen some half-way up the shore, they do not thrive unless protected from the sun. As a pool-plant it is one of the commonest species, and is then usually infested by Ectocarpus fasciculatus, Ceramium Bocrgesenii, and Herponema velutino. In the open, Elachista scutulate is the usual epiphyte.

\section{Corallina and Lithothamnium Associations.}

A belt of Corcllina spp. is found just above low-water mark in many parts of Clare Island. It is characteristic of very exposed rocks, where it appears to take the place of the Larurencia pinnatifida band of less open spots. An extensive growth of encrusting algae is usually met with as an undergrowth, and the two types of vegetation appear to be intimately connected, and may for the present be treated together, 
The species concerned are as follows:-

Corallina squamata, dom.

C. officinalis, eo- or sub-dom.

Lithothamnium Lenormandi.

Lithyphyllum incrustans.

Lithothamnium polymorphum.)

Undergrowth, in zones,

(a) The Corallina growth is very much worn down by the waves, so that it occurs in the form of dense cushions, the specific identity of which is difficult to ascertain. In shallow depressions or with slight shelter, the production of larger and more perfect fronds allows their true nature to be determined, and in each case examined it was evirlent that the bulk of the growth was composed of $C$. squamata, though $C$. offeinatis was at times also present.

The first signs of the Corallina belt are found at about half-tide level, usually just below the top of the Nemalion zone. The plants are found here in chinks and fissures, where there is little risk of drying, and on passing downwards they gradually spread out over the surface of the rocks. They are, especially in the upper parts, frequently attached to mussels; and the growth of these two organisms together form the compact cushions referred to. At the lower part of the zone the fronds are large. This is due partly to their being protected by the Laminaria foliage, and partly to their being below the level at which the waves break. A great improvement in colour is at the same time noticeable. C. squamate as well as C. officinalis occurs at the top of the Laminaria belt; and the latter certainly, if not indeed both, descends some distance into the sub-littoral region.

With increased shelter, though the plants are larger and less broken by the wares, the band as a whole is not so conspicuous, owing to its being replaced by other algae (usually Laurencia). Shallow pools are an exception. Here a fine growth of $C$. officinalis is often present, and less frequently C. squamate. 'I'he latter is seen at its best on narrow ledges, or hanging from the sides of shady rocks.

The Corallina association above dealt with differs floristically from all others hitherto described, in being composed largely of the southern species C. squamatu. This is probably the case in all the warmer parts of the British Isles. 'There is no question as to the abundance of $C$. squamata in Clare Island; and it is doubtless equally common along the whole of the south and west of Ireland. It also occurs in plenty in the south of England, and has been noted as forming the principal constituent of the Corallina association at the end of Portland Bill.

(b) The Lithothamnium vegetation is described here together with that of Corallina, because it is exceptionally well developed when found in company 
with a widespread growth of that algi. It thorongh study of its occurrence in varying conditions was not made; consequently the following notes must be regarded as but a contribution to the study.

The growth in question occurs in three zones, Lithothannium Lenormandi, the uppermost, Lithophyllum incrustans, the second, and the third, Lithothamnium polymorphum; appears only when low-water mark is reached. All three plants resent desiccation, and cannot bear being dried np. L. polymorphum, and, to a lesser degree, L. Lenormundi, prefer shade; but $L$. incrustens thrives in the bright sunshine of shallow rock-pools. The zone of $L$. Lcnomandi occurs on damp rocks slightly above half-tide level, at which height moisture is local, being found in fissures, on shady vertical surfaces, or under the foliage of the larger algae. The zone is more extensive than at first sight appears, and is probably widespread in the British Isles. $L$. incrustans follows. 'This is abundant in all the rock-pools, and is by far' the commonest species in the district. Apart from its growth in pools, L. incrustans first appears in chinks and hollows in the lower half of the littoral region. As one descends the shore the crusts become larger and more widely spread; and on reaching the Himanthalia level they form large sheets, filling up interstices between limpets, barnacles, and Ralfsia clavata. At low-water mark the plant is joined by $L$. polymorphum, the red warty thallus of which is at once distinguishable from the paler $L$. incrustans, though the latter at this level assumes its true mauve-pink colour, in contrast to its almost white appearance higher up. L. polymorphum extends into the sub-littoral region; $L$. incrustans probably does the same, but its growth here on exposed shores was not investigated.

The Lithothamuium regetation described above is specially characteristic of exposed, somewhat bare rocks, where algae such as Laurencia and Himanthalia are poorly developed, but where there is a large growth of the short form of Corallina. In localities where there is less exposure, or where shrubby and foliaceous algae occur in plenty, the Lithothamnium regetation is poor: some traces of the $L$. Lenomandi and $L$. polymorphum zones may be found, but $L$. incrustans usually disappears altogether.

\section{Vegetation of Rock-pools.}

Several different types of pools may be distinguished according to their elevation, and to the geological nature of the shore. A number of other factors must also be taken into consideration-namely, the size, depth, and configuration of the pouls, and conditions of temperature, illumination, and drainage. Whilst much of the pool-vegetation is perennial and more or less constant, a large part is transient and varies considerably, not only from month to P. I. A. PROC., VOL, XXXI. 
month, but from one year to another. A detailed study and analysis of the vegetation was impossible; but a series of observations was made, and a general account is given below.

In the upper pools an encrusting vegetation is always conspicuous. At the highest levels Hildenbrandtia prototypus is found, especially on rugged rouks and on exposed cliffs. Slightly below, and generally in Hatter areas, Rulfsin verrucosa appears, covering the bottom of shallow pools with a thick crust, and often completely ousting Hildenbrandtia. At a lower level (probahly that of ordinary high-tide), Lithophyllum incrustuns begins to develop, first as a very thin crust which does not fruit; then rapidly increasing in vigour on the lower rocks, it passes into the Lithothamnium association (p. 41). Ralfsia and Lithophyllum are, in the upper shallow pools, in competition. The former cakes off with age, allowing Lithophyllum for a time to get the upper hand. Ralfsia, however, tolerates more fresh water, and probably grows more rapidly. Both can withstand intense insolation, and often form large sheets without any protecting vegetation whatever. The water of these pools becomes in summer very warm.

With regard to the upright vegetation, Enteromorphe intestinalis is of ten alone in the highest pools, but is joined by Cladophore sericea, Chatomorylue acrea, and Scylosiphon lomentarins, where the salt-water is constantly renewed by spray and splashing. Below these a series of fairly characteristic pools, situated about high-water level, is reached, which are well supplied with seaweeds during winter and spring. But in summer the larger algae are scarce, or represented by a few hardy species, usually infested with Diatoms and Cyanophyceae. The dominant species are:-

Cladophora rupestris.

C. sericea.

Scytosiphon lomentarius.

Leathesia difformis.

Gelidium $s p$.
Gigartina mamillosa.

Laurencia hybrida (except summer).

Polysiphonia fruticulosa.

Dumontia filiformis (except summer).

Corallina officinalis.

The additional winter and spring flora need not be listed. The pools are not always replenished in calm weather, and are distinctly brackish; they are about 6 inches deep, and commonly run parallel with the shore.

At a lower level the typical purely marine rock-pools commence, in varied form, and with abundant vegetation. They are much more difficult to classify, and have a constantly changing flora. With a sufficient depth, large algae, such as Halidrys, Cystoseira fibrosa, \&c., are plentiful, and provide shade; hence almost any of the shade-loving Florideae (except those which require daily exposure to the air) may be met with. If shallow, the flora is more limited, 
though sporelings and young plants of a very large number of species vccur. In Vancouver, Henkel ('06) has worked on the structure of rock-pools; and Skinner's paper ('03) is one of the only attempts to analyse the flora and the conditions obtaining. His conclusions, equally applicable to the British coasts, are as follows:- In general, the higher the elevation of the pool, and the less exposed to wave-action, the fewer the species found, though the number of individuals may be great. The more gradual the slope, and the rougher and more irregular the sides, the more abundant the plant-life. A perpendicular or receding wall is unfavourable for the location of plants.

An attempt is made below to indicate the characteristic species of ordinary rock-pools not more than 18 inches deep. A complete list is out of the question. In a general way they are at their best in early spring. During the dark days of winter many of the Florideae, which at other seasons thrive in more shady spots, are found in shallow pools (e.g. Phyllophora rubens, Plocamium coccineum, Laurencia obtusa, Rhodomela subfusca, Falurus equisetifolius). Hence in winter and spring the Florideae are markedly dominant. In March and April many transient species develop; and in May and June brown algae are abundant, and also species of Cladophora. The Floricleae in shallow pools are in summer of poor colour; and a great decrease in the number of species is noticeable. Ulva and Enteromorpha spp. may he dominant in August and September. Excluding large species, such as Fucks, Laminarin, \&e., and small epiphytes like Myrionema, Elachista, and Chantransia, the most typical species are as indicated in the list on pp. 44,45 .

\section{Cave-Tegetation.}

As would he expected from the conditions obtaining in caves, shade-loving littoral plants abound; whilst in addition species from the sub-littoral region also occur. Provided wave-action is not too severe, the cave-flora is often full of interest biologically, long tunnel-like caves, with pools and boulders, being particularly instructive.

'Though the Clare Island caves are neither numerous nor extensive, their flora is characteristic and worthy of record. 'l'hey may be roughly divided into two sets, namely, exposed and sheltered. The flora of caves fully exposed to the sea is usually poor, incrusting species on the walls being at times the only vegetation present; but sheltered caves, especially if stocked with boulders, are rich in species, and possess the shaggy growth of which Plumaria is typical, as well as the mossy and incrusting coverings supplied respectively by Rhodochorton Rothii and Lithothamnium polymorphum. 
Characteristic Vegetation of Rock-pools.

\begin{tabular}{|c|c|c|c|c|}
\hline - & $\begin{array}{l}\text { Feb., } 1911 . \\
\text { Roonah Pt. }\end{array}$ & $\begin{array}{l}\text { April, } 1911 . \\
\text { Clare Island. }\end{array}$ & $\begin{array}{l}\text { July, } 1909 . \\
\text { Clare Island. }\end{array}$ & $\begin{array}{l}\text { Uch., } 1910 . \\
\text { Clare Island. }\end{array}$ \\
\hline Monustroma Grevillei, & - & $\times a b$. & - & - \\
\hline Enteromorpha elathrata, . & - & $x$ & $x$ & $\times a b$. \\
\hline E. compressa, . . & $x$ & $x$ & $\times a b$. & $\times a b$. \\
\hline Ulva Lactuca, . ' & $x y$ & $x$ & $\times a b$. & $\times a b$. \\
\hline Rhizoclonium implexum, . & - & $\times$ & $x$ & - \\
\hline Cladophora pellucida, & - & $x$ & - & - \\
\hline C. rupestris, & $x$ & $x$ & $x$ & $x$ \\
\hline C. sericea, & $\times y$. & $x$ & $x$ & $x$ \\
\hline C. glaucescens, . & - & $x$ & - & - \\
\hline C. albida, . & - & $x$ & - & - \\
\hline C. lanosa, . & - & $x$ & - & - \\
\hline Codium adhaerens, & - & $x$ & $x$ & $x$ \\
\hline C. tomentosum, & $x$ & $\times r$ & $x$ & $x$ \\
\hline C. mucronatum, & $\times y$ & $x$ & $x$ & $x$ \\
\hline Dictyosiphon foeniculaceus, & - & $x$ & $x$ & - \\
\hline Litosiphon pusillum, & - & - & $x$ & $x$ \\
\hline Phloeospora brachiatum, & - & - & $x$ & - \\
\hline Scytosiphon lomentarius, . & $x$ & $x$ & $x$ & $x$ \\
\hline Ectocarpus confervoides, & - & $x$ & $x$ & $x$ \\
\hline E. fasciculatus, & - & $x$ & $x$ & $x$ \\
\hline E. granulosus, & - & $x$ & $x$ & - \\
\hline Pylaiella litoralis, & $x$ & $\times$ & $x$ & $x$ \\
\hline Ismophloea sphaerophora, . & - & $x$ & - & - \\
\hline Myriotrichia claviformis, . & - & - & $x$ & $x$ \\
\hline Sphacelaria cirrhosa, & $x$ & $x$ & $x$ & $x$ \\
\hline Cladostephus verticillatus, . & $x$ & $x$ & $x$ & $x$ \\
\hline Chordaria flagelliformis, & - & - & $x$ & $x$ \\
\hline Mesogloia vermiculata, & - & - & $x$ & - \\
\hline Castagnea virescens, . & - & - & $x$ & - \\
\hline Lenthesia tuberiformis, & - & $\times y$ & $\times a b$. & $x$ \\
\hline Dictyota dichotom & $\times y$ & $\times a b$ & $\times a^{h}$. & - \\
\hline Porphyra leucosticta, & - & $x$ & - & - \\
\hline P. umbilicalis, . & $x$ & $x$ & $\times r$ & - \\
\hline Pterocladia capillacea, & - & $x$ & $\times r$ & - \\
\hline Gelidium pulchellum, & - & $x$ & $x$ & $x$ \\
\hline G. latifolium, . & - & $x$ & $x$ & $x$ \\
\hline Chondrus crispus, & $x$ & $x$ & $x$ & $x$ \\
\hline Gigartina mamillosus, & $x$ & $x$ & $x$ & $x$ \\
\hline Phyllophora rubens, & $x$ & $x$ & $x$ & $x$ \\
\hline
\end{tabular}


Feb., 1911. April, 1911. July, 1909. Oct., 1910. Roonah Pt. Clare Islund. Clare Islund. Clare Island.

Cystocloniun purpurascens,

Calliblepharis jubata,

Rhodymenia palmata,

Lomentaria articulata,

L. clarellosa

Chylocladia kaliformis,

C. ovalis,

Plocamium coccineum,

Nitophyllum punctatum, .

N. laceratum,

$x$

$\times$

$x$

Delesseria sanguinea,

D. ruscifolia,

D. hypoglossum,

Rhodomela subfusca,

Laurencia obtusa,

I. hybrida,

L. pinnatifida,

Polysiphonia urceolata,

$P$. nigrescens,

P. Brodiaei,

P. fruticulosa,

Pterosiphonia thuyoides,

Dasya arbuscula,

Spermnthamnion Turneri, .

Griffithsia setacer,

Halurus equisetifolius,

Monospora pedicellata,

Plumaria elegans,

Ceramium rubrum,

C. Boergesenii, .

C. ciliatum,

Dumontia filiformis, .

Dilsea edulis,

Furcellaria fastigiata,

Lithophyllum lichenoides, .

Corallina officinalis,

C. squamata

C. mbens,

\section{$-$}

$x$

$\times a b$.

$-$

$-$

$\times a b$.

$\times a b$.

- $\quad \times r$

$x a b, y$.

$\times a b$.

- $\quad \times$ r.

$-$

$x$

$\times r$

$\times a b$.

$\times$

$x$

$x$

$\times a b$.

$\times$

$\times$

$x$

$-$

$x$

$-$

$x$

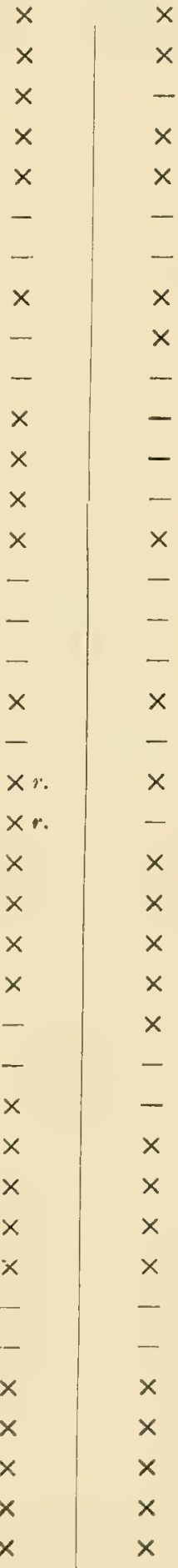


1. Erposed Caves. - Several of these occur between Portlea and the lighthouse, and are accessible at low tide. The walls, almost up to the roof, are covered with encrusting organisms representing algae, lichens, and sponges; and except for local patches, shrubby species are absent. In the following list, the first four are dominant, occurring roughly as bands from above downward in the order mentioned, whilst the three last are scattered irregularly a short distance above high-water mark :-

Hildenbrandtia prototypus.

Verrucaria $s p$.

Lithothamnium Lenormandi.

L. polymorphum.
Lithothamnium laevigatum. Ralfsia clavata. Cruoria pellita.

Large sheets of sponges also occur, and amongst these Halichondria penicea, frequently with Rhizoclonium Kerneri f. endozoica, is abundant.

Small patches of a very short growth of the following fruticulose species are occasionally found, their presence probably indicating local shelter :-

\section{Phyllophora rubens. \\ Chylocladia ovalis.}

Plumaria elegans.

Corallina officinalis.

Where fresh water exudes from the roof or walls, streaks of Cladophora. mupestris, if the exposure be not too great, mark its presence, and at times Rhodochorton floridulum in addition. Pools are generally lacking; if present, their flora resembles that given below for sheltered caves.

2. Sheltered Caves.-Several types of these may be distinguished according to the nature of the shore and the mammer in which they receive protection. In our area the two following only need be mentioned:-(a) Open caves on exposed coasts, protected by rocks at the entrance (Roonah Point); and (b) high-level caves with the entrance at, or just above, high-water mark. In the former there is often a variety of ground and vegetation, especially if boulders and pools occur; in the latter the conditions are more uniform.

(a) The encrusting vegetation at Roonah Point is the same as that on exposed coasts, but less extensive; the mossy growth of Rhoclochorton Rothii is abundant on the drier boulders and on the upper parts of the walls; Sphacelaria britannica and various Cyanophyceae occur with this species, and Phyllophora Traillii is found in patches. An abundant growth of shadeloving Florideae follows at a lower level, covering rocks, boulders, and shallow pools, Chylocladia articulata, Delesseria alata, Nitoplyyllum laceratum, Polysiphonia urceolata, and encrusting species such as Lithothaminum 
Tenormandi and L. polymorphum being the most usual. The pool-flora consists chiefly of the following species:-

Phyllophora rubens.

P. membranifolia.

Rhodymenia palmata.

Nitophyllum laceratum.

Delesseria sanguinea.

Plocamium coccineum.
Polysiphonia urceolata.

Chylocladia articulata.

Griffithsia setacea.

Pterosiphonia parasitica.

Lithophyllum incrustans.

Lithothamnium polymorphum.

(b) A small tunnel-like cave on the south side of Portlea was carefully investigated each season. Though short, it was the only really dark cave examined, and its flora proved of considerable interest, three of the rarest algae of the island occurring in it. Near the mouth of the cave the shaggy growth lining the walls consisted of Cladophore rupestris (dominant) and Plumaria (sub-dominant), with the following species scattered freely amongst them :-

Ectocarpus Holmesii.

Gelidium pusillum.

Rhodymenia palmata.

Polysiphonia urceolata.
Polysiphonia macrocarpa.

Rhodochorton floridulum:

Callithamnion scopulorum.

Spermothamnion Turneri.

A little further in, Plumaria becomes dominant, and, with the exception of Cladophora rupestris, which assumes a thin feebly branched habit, the other algae gradually disappear. On the bottom and at the margins of pools, Derbesice marina is found, and on the sloping sides Codium amphibium under the drip of fresh water. At the further end, the walls are mostly clothed with a pure growth of Plumaria, though patches of Lithothamnium Lenormandi var. squamulosa exist, and Derbesia occupies the water-edges. The pool-flora is remarkable; Plumaria, Ceramium acanthonotum and Polysiphonia macrocarpu are common, whilst further in there is a felt of the minute Ptilothamnion lucifugum (sp. nov.).

\section{(b). Sub-littoral Region.}

The sub-littoral vegetation of exposed coasts is difficult of exploration. In caln weather much may be learnt from a boat at dead low water, but in a general way a small boat and a hand-dredge are of little use. Two associations only are described below, these being the only ones which were definitely investigated. Colonies of the beautiful Cystoseira ericoides are plentiful off the sbore, in company with such plants as Saccorhiza and Himanthalia, but unfavourable weather baffled attempts at their study. 
Laminaria Association.

Clare Island is girdled at low-water mark with a fine belt of Laminaria, which descends on all sides deep down into the sub-littoral region. With the exception of the somewhat doubtful $L$. hicroglyphice, all the English species wceur, so that the west of Ireland presents the exposed Laminaria vergetation of the British Isles in its most varied form. Though a submerged assuciation. wach species reaches to the top of the sub-littoral region, and is thus visible during the lowest spring-ticles. Alaria and L. diyitute sre uppermost, and are often uncovered; Saccorhiza and L. sacchrorine follow, and usually show in calm weather, whilst the erect stipes of $L$. Clonstoni protrude in favoured localities only. Alaria, $L$. digituta, and $L$. Cloustoni form well-marked belts which are always to be found on the type of shore that they respectively require, whereas the growth of Saccorhiza, and $L$. saccharina, though at times plentiful, is seattered and local.

A steep coast with almost perpendicular rocks is the Alaria shore par excllence, though $L$. digitata is also usually present. On sloping rocks the same vegetation obtains, the amount of $L$. digitate increasing as the shore becomes less steep, till at length Alaria disappears altogether. L. digitata often descends into many fathoms (at least 8); but Alaria appears to form a shallow helt in the uppermost part of the littoral region. L. Cloustoni enjoys the Atlantic swell, but prefers a Hat bottom, and is absent on steep rocks. Within the shelter of a reef, or in other similarly protected spots, the plants are found nearer the surface of the water, and at the lowest tides the tops of their stipes protrude. In such positions the association may be conveniently examined from a boat (e.g., at Roonah Quay).

A flat or gently sloping bottom with a certain amount of shelter is most suitable for Saccorhiza and $L$. succharina. In certain spots on the south shore, and especially in channels between the rocks, the former grows in plot-like areas, which may be easily examined from the rocks in quiet weather. It is also plentful in the shallow water off Kinnacorra. Streak-like patches of L. succhrimu have also been noted in these localities, but the plant is more characteristic of quiet regions.

As stated on p. 15, the Laminaria association, though it may be partially uncovered during spring-tides, marks in reality the upper limit of the sublittoral region. The amount uncovered varies with the exposure. In the most boisterous spots Alaria ascends high, and consequently, if a spell of quiet weather syuchronizes with spring-tides, a considerable amount, 3-5 feet, is left bare. Börgesen mentions a case in the Faeröes, where Alaria flourisher at a level above that of high-water line. Nothing like this has been seen in 
Ireland, and it probably only occurs where great exposure is coupled with a. wet, foggy climate.

The nsual epiphytes characteristic of the species occur. Litosiphon Alariae, Éctocarpus fasciculatus, and Mvrionemaceae are frequent on AlariaChantransice Alarice rare. The laminae of $L$. digitata commonly bear a copious growth of Ectocarpi, Ceramia, Callithamnion tetragonum, and other small plants, while the stipes are usually clean. The rugged stems of L. Clonstoni, on the other hand, are densely clothed with Florideae, which show a tendency to definite sequence from above downwards as pointed ont by Berthold ('82) and Börgesen ('05). As a rule this sequence is as follows:-
Rhodymenia palmata.
Polysiphonia urceolata.
Delesseria sinuosa.
Delesseria alata.
Heterosiphonia coccinea.

But in addition to the differences due to seasonal variations many irregularities were noted. Other characteristic epiphytes are :-
Codium tomentosum.
Ptilothamnion pluma.
Callophyllis laciniata.
Ptilota plumosa.
Rhodymenia palmetta.
Plumaria elegans.
Lomentaria articulata.
Rhodochorton parasitica.
Plocamium coccineum.
Cruoriella Dubyi, $r$.
Nitophyllum laceratum.
Cruoria pellita $r$
N. uncinatum (autumn).
Petrocelis Hennedyi $r$.
N. Bonnemaisoni, $r$.
Dermatolithon pustulatum.

Saccorhiza is usually fairly clean, as is also L. saccharina in exposed localities.

Comparison with other Countries.-As far as Alaria, L. digitata, and L. Cloustoni are concerned, the above vegetation agrees well with that described by Börgesen for the Faeroes, though in that region it ascends somewhat higher on the shore. Saccorhiza is entirely absent; but this is compensated for by the presence of two additional species, A. Pylaii and $L$. fueroensis, the latter being confined to sheltered coasts. Börgesen, in an interesting paragraph on the effect of wave-action on Laminariae, points out that the pliable stipes and fronds of Alaria and $L$. diyitut" are able to resist the violent conditions of a steep shore, and where the breaking of the waves is felt; whilst the stout and comparatively rigid stems of $L$. Cloustoni are suited to the strong pull of the rollers in deeper water. 
The Swedish vegetation described ly Kylin is very different. Alaria is absent, and the verticai rocks are clothed with $L$. digitata and $L$. sacchurina var. bullate. In the most open spots $L$. digitata var. cuncerta is dominant. The $L$. Cloustoni vegetation is entirely separate from $L$. digituta, being found only in the deeper part of the sub-littoral region, appearing first in about $15 \mathrm{~m}$. of water. Boye's account of the Norwegian flora (according to Börgesen's summary) agrees with that of the Faeröes; and Kylin's notes on the vegetation near Bergen ('10) indicate the preponderance of Alaria and L. Cloustoni. The Iceland vegetation resembles that of the Faeröes, but is enriched by the presence of $L$. nigripes and Succorliza dermatodea. In the south of England Alaria is rare except in Cornwall, but apart from its absence the Clare Island vegetation agrees well with that noted in Dorset. The exposed rocky coasts of Ireland are, however, more favourable for an extensive Laminaria vegetation, and are highly suitable for a growth of Alaria.

\section{Encrusting Alga Vegetation (sub-littoral).}

The Lithothamnium vegetation of the littoral region extends downwards into the deepest parts of the sub-littoral, but, owing to the difficulty of dredging amongst a dense growth of Laminuria digitata and $L$. Cloustoni, it is difficult to ascertain the amount of growth and the relative abundance of the species. An extensive coating of calcareous algae is, however, present, and on exposed coasts probably occupies a large part of the available rock-surface, though soft encrusting species, such as Cruoria pellitı, Cruoriella, and Peyssonnelia, occur with it. Lithophyllum incrustans enters the sub-littoral; but, as far as could be seen, the Lithothamnium "band at the lowest tide-level consists mainly of L. polymorphum, and this extends downwards for several fathoms. Other species dredged were $L$. laevigutum and $L$. compuctum. The fruticulose calcareous algae, such as $L$. calcareum and $L$. fasciculatum, are characteristic of sheltered shores ( $\mathrm{p}, 69)$.

\section{B.-Sheltered Coast Series.}

(a) Littoral region.

Several of the associations found on sheltered coasts have been already dealt with. In some cases the principal differences noticeable in passing from the open shores to quieter conditions have been pointed out, so that re-description is unnecessary. In other cases, though theassociations have been described, their growth in sheltered localities requires special notice; yet other communities are peculiar to such regions. 
Hildenbrandtia-Verrucaria Association.

Brief notes may be added to previous remarks with regard to this association (p. 19). On the sheltered shores of Clew Bay the same species are present, especially on boulders and smooth rocks. Where these are absent a discontinuous growth on stones and pebbles occurs, and in such spots Hildenbrandtia is joined near low-water mark by Porphyrodiscus simnlans and Khododermis elegans (plants harlly distinguishable in the field), and also by Ralfsia clarata. $H$. prototypus itself, moreover, appears to extend to the sub-littoral region (cf. p. 20). The difficulties of obtaining satisfactory material and of distinguishing the species when collecting, make it no easy matter to gain a true idea of the different societies. It is certain, however, that in these localities the Ralfsic clavate vegetation is one with the Hildenbrandtia association, and that it forms a part of it. It is further evident that a vegetation composed of soft encrusting algae and lichens extends uninterruptedly from high-water mark down to the Lithoderma association of $\tilde{0}-8$ fathoms. The details require working out, but roughly the principal species form zones as follows:-

Hildenbrandtia prototypus (upper littoral).
Verrucaria mucosa (niddle littoral).
Ralfsia clavata (lower littoral).
Cruoriopsis Dubyi (shallow sub-littoral).
Lithoderma fatiscens? (shallow sub-littoral).

Fucaceae Association (sheltered).

The growth of Fucaceae on Hat sheltered shores is exceedingly luxuriant, and often forms a conspicuous feature of the landscape. The indispensable factor is good anchorage. On flat shores, where wave-action is slight stones are sutticient to supply this necessity, but where rocks and stones are wanting Fuci are conspicuous by their absence. The association was studied especially in Achill Sound, the north part towards Inishbiggle and Bellacragher Bay having been examined, as well as the southern portion towards Achillbeg. As far as was seen the Fucus growth in Clew Bay is of a precisely similar nature.

The association is composed of the usual five species in their normal sequence (see p. 23), and where fresh-water streams occur, the sixth species, $F$. ceranoides, invariably appears. In some places the zones are fairly sharply defined; in others they are much less distinct, and each zone overlaps the next. A certain amount of irregularity exists ton as to the order in which Ascophyllum and $F$. ccsiculusus vecur. The former usually commences above 
the latter; but not infrequently $F$. vesiculosus forms a very wide zone reaching from $F$. spiralis down to $F$. serratus, with Ascophyllum scattered amongst it, or forming more or less of a band in the upper part. The reason for this is explained later. At times one or more of the species may be absent, and this may almost always be traced to lack of suitable means of attachment at the appropriate level. In Achill Sound, for instance, the association often stops abruptly with Ascophyllum or $F$. vesiculosus, owing to the absence of stones at the level at which $F$. serratus should occur. In other places Pelvetia and F. spiralis are only feebly developed owing to the lack, in the upper part of the shore, of stones of sufficient size.

Some idea of the width of Fucus association in Achill Sound will be gained from the following readings:-

A. Sloping shore near Achill Bridge with a narrow band of Fucaceae:-

\begin{tabular}{|c|c|c|c|c|c|c|c|c|c|}
\hline \multicolumn{10}{|c|}{ Width of zond } \\
\hline Pelvetia, . & . & . & . & . & . & & - & $2-3$ & feet. \\
\hline F. spiralis, & . & . & . & . & . & & . & $5-6$ & $"$ \\
\hline F. vesiculosus, & . & . & . & . & . & . & . & 10 & $" 1$ \\
\hline F. vesiculosus ar & nd $\mathrm{A}$ & scoph & yllu & & & . & . & 10 & $"$ \\
\hline F. vesiculosus, & . & · & · & . & . & . & - & 10 & , \\
\hline F. serratus, & . & . & . & . & . & . & . & 10 & , \\
\hline
\end{tabular}

B. Flat shore with a very wide Fucus association; about 1 mile south of Achill Bridge :-

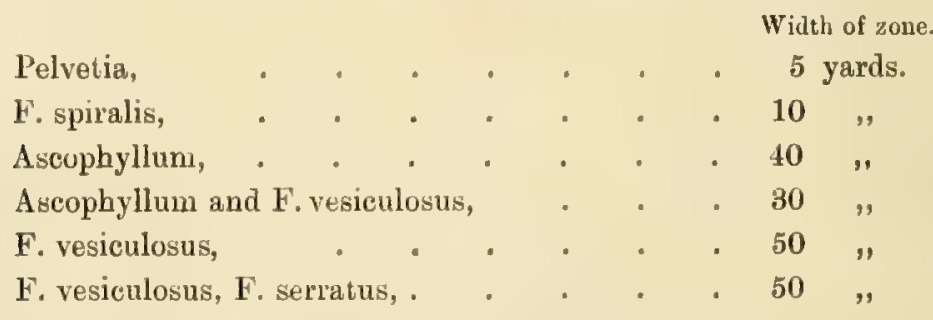

The above figures represent fair average readings for sloping and flat shores respectively, and serve to show that the horizontal range varies directly with the amount of slope. On very flat shores even wider bands exist. At Mulranny, for example, on a flat stretch of rocks and stones at high-water livel, a growth of Pelvetia 80 yards wide was noted: this was followed by a sudden increase in the fall, and the succeeding band of $F$. spiralis was only 3-4 yards in width.

With regard to exposure, all the species composing the association can tolerate the extreme shelter of the inner part of Clew Bay. On passing from this region to the nore open, beyond a slight change in form, there is no 
marked difference in the vegetation as long as Ascophyllum remains. A slight exposure, however, is sufficient to affect this species, and with its disappearance the association is robbed of one of its most conspicuous elements. Ascophyllum begins to disappear on the outer sides of the islands, but persists in all cases on the inner sides. West of the islands it is only found in certain places, though this perhaps is largely due to the lack of good mooring. But, in spite of this, there is no question whatever that in the Survey-area Ascophyllum is far more susceptible to exposure than F.vesiculosus. This is in agreement with observations in other parts of the British Isles, and also with accounts that have been given of the Norway Fucus-vegetation (Boye, '94, and Kylin, '10). The conditions described for the Faeröes, where Ascophyllum is the less susceptible of the two, are very remarkable, and, as far as known, unique. The result of exposure in producing a change in form in the various constituents of the association is very marked. It is best seen in $F$. spiralis. $F$. vesiculosus also produces a wealth of form, but the variations are more difficult to connect with external conditions. Remarks on these points occur in the notes on each species given later.

Fucus Farms. - The botanical features of the plots, planted with stones in order to obtain a growth of Fucus for use as manure, may be dealt with here. The farms are formed on flat stretches of sand exposed at low water. They may either extend from the shore, or be laid out as isolated patches in the middle of the strand. The rapid colonization, and the luxuriance of the subsequent vegetation, prove beyond question the effect of anchorage.

The stones are covered mostly by $F$. vesiculosus, though a small amount of Ascophyllum somotimes occurs. At the lowest levels there are occasionally encircling belts of $F$. serratus, but the stones are not as a rule placed sufficiently low for this species. F. vesiculosus is very luxuriant, forming large tufts, bright yellow in summer and deep green in winter, with numerous bladders and abundant fruit. $F$. servatus, when present, grows equally vigorously, with fine broad fronds often a yard in length. The plants are cut in February after two full years' growth, and the stones turned over for a new crop of sporelings to develop.

It is somewhat remarkable that this artificially produced vegetation consists of a practically pure association of $F$. vesiculosus, forming thus a striking contrast to vegetation obtaining on mud-flats (e.g., Belfast Lough, Southampton Water). The latter are colonized by mussels, and these support a pure growth of Ulva Lactuca. Ulva, and many other adaptable algae, are present in Clew Bay, but Fucus has complete sway on the stone plots. It would be interesting to know whether Fucus would develop if stones of sufficiently large size could be maintained on the mud-tlats of Belfast Lough. 
A few notes are appended on the species composing the association.

(a) Pelvetia canaliculata.-This is less variable than any other species. In the sheltered parts of Clew Bay and in Achill Sound, it usually occurs on the irregularly scattered stones, and consequently the zone is interrupted. The growth is entirely flooded at spring-tides, but at neap-tides the upper part of the belt is unmoistened, the plants remaining quite dry, and brittle for several days in succession. Though Pelvetia may form a zone several yards wide, its vertical distribution is not more than $1 \frac{1}{2}-2$ feet. It fruits freely during summer and autumn; but the growth being more interrupted and not so luxuriant as on open shores, the orange-yellow band is not so conspicuous.

(b) $F$. spirulis.-Not only is $F$. spiralis found in all the sheltered parts of Clew Bay, but it is capable of growing on peat and loam, and ranges from such situations to the roughest and most exposed parts of the open coast (cf. Börgesen, '05, p. 746). Leaving aside its growth on peat (see p. 124), we find that on flat shores the plants are usually stone-attached, and do not form so dense a vegetation as when growing on rock. For this reason they become drier during the long exposure to the air, and are shorter and less branched. When the shore is composed of rocks and large stones, the growth is more vigorous; and under these conditions the plants attain their maximum size, the fronds being wide, much branched, and bearing large fleshy conceptacles. 'I'his form remains as long as the conditions are sheltered, but when exposure is experienced, or where a current strikes the shore, the plants become shorter, though they usually retain their bushy habit.

The belt formed is much wider than on steep open coasts, and its width is proportional to the degree of slope. In Achill Sound it varies from a few feet to 10 yards, and usually forms a pure growth, though $F$. vesiculosus and Ascophyllum occasionally intrude into the lower part. The fruiting season on quiet shores appears to extend over a slightly longer period than on those which are more open. In Clew Bay it commences in May, and does not cease till autumn. On sheltered shores also, a difference in colour is noticeable luring the autumn, the plants turning a bright rusty brown. The same peculiarity has been observed on the south coast of England; and it serves to distinguish at a glance $F$. spiralis from $F$. vesiculosus, the latter being usually yellow or only slightly brown. In some places two sharp zones of colour are produced. Another feature, which on flat shores is very characteristic of $F$. spiralis, is the presence of long blister-like swellings on the fronds. 'I'hese are invariably present in the inner part of Clew Bay, and are entirely absent from the short forms found on Clare Island. Sauvageau has lately examined $F_{\text {spiralis }}(=F$. platycarpus, 'Thur.) with great thoroughness ('08). 
(c) Ascophyllum and F. resiculosus.-The irregularities in the vertical range of Ascophyllum and $F$. vesiculosus have been noted by several writers. Börgesen calls attention to the difference in the observations of Strömfelt in Iceland, and Rosenvinge in Norway; and records irregularities noted by himself in a single locality in the Faeröes. He comes to the conclusion that the difficulty may be explained by the factor of exposure and small differences in local topography. No doubt this solution is correct with regard to many localities; but in Achill Sound it was found inadequate, and a further explanation had to be sought for. It has always been assumed that in England the Ascophyllum zone begins slightly above that of $F$. vesiculosus, and Miss Baker ('09) gives figures which support that view. 'This sequence is found on the stone embankments of Achill Bridge and in other places; but on the shores in Clew Bay, as often as not, the reverse order obtains. The explanation, so far as the sheltered waters of the Survey area are concerned, was found to be largely one of anchorage. Ascophyllum requires a stronger mooring than Fucus; and on the sandy shores of Clew Bay where the stones in the upper part of the beach are small they are insufficient for Ascophyllum, though well able to provide a mooring for a short growth of Fucus. The absence therefore of the Ascophyllum-zone, or the presence of scattered plants only, is explained by the absence of rock and large stones at the right level, or the presence of isolated rocks only. In many parts of the Sound the anchorage is sufficiently good to allow Ascophyllum to flourish at all levels, and then the normal sequence is almost invariably maintained. Very small stones suffice for both $F$. spiralis and $F$. vesiculosus; but it is unusual to find even young plants of Ascophyllum on stones. The last-named shows a decided preference for boulders, from which it hangs in festoons. The stone-attached Fucus-vegetation is essentially one of very sheltered water, and could not exist were there much wave-action. Where the stones are light the growth is small, and if, by reason of a long spell of quiet weather, an extra amount of foliage should be produced, a number of plants will be displaced with the first ruffling of the water.

Ascophyllum fruits in late winter and spring. In summer and autumn a large amount of vegetative growth takes place; and young receptacles are laid down in autumn. The latter begin to ripen in March, the main crop of spores being liberated in April and May. The effect of exposure has been dealt with above.

The Frucus vesiculosus belt is the widest. On flat shores it ranges from 20 to 80 yards, in the upper part usually accompanied by Ascophyllum, but near low water often pure. No attempt was made to determine all the forms; but the most abundant is the ordinary type. Var. vudorum is also common, 
and var. laterifructus not infrequent. In many localities var. axillaris is found, which under certain conditions passes into $F$. volubilis, Huds. The latter in its typical form was not noted in the area; but the salt-marsh plant var. baltica is abundant. This, together with a peculiar variety named muscoides, is dealt with later (p. 80).

(d) Fucus serrutus. Whilst Ascophyllum enjoys hanging from boulders, $F$. servatus prefers to lie flat. Occasionally it is found growing on sand-covered rocks, and then rests on the bare sand. It is found on all sheltered coasts where there is appropriate anchorage; but in many parts of Clew Bay this is wanting; and the pebble-attached association sets in below $F$. vesiculosus. $F$. serratus forms a band which unites the littoral and sub-littoral regions. The fronds are wider on sheltered than on exposed coasts; and on the whole it is the least variable Fucus.

Sub-vegetation.-When growing on sloping rocks a luxuriant undergrowth of various algae is found; but when attached to stones, or where much sand occurs, extraneous species are scarce. Amongst those almost constantly present are :-

In upper part.

Hildenbrandtia,

Catenella.

Gelidium pusillum.

Cladophora rupestris.
In lower part.

Cladostephus spongiosus.

Ulva.

Ceramium rubrum.

Chondrus.

Gigartina.

C. rupestris.

On the more open shores where clean rocks are prevalent, the LaurenciaGigartina vegetation often forms the main undergrowth, though upward extensions of the Corallina-Lithothamnium association are also frequent. Amongst these, such sub-littoral or shade-loving plants as Chylocladiu articulata, Delesseria alata, and Plumaria occur, with many odd plants of various communities. In sandy places a Rhodochorton floridulum vegetation is often developed, and this ousts many of the other species.

Epiphytes.-These are likewise fewer in very sheltered than in moderately open localities. In the quiet reaches of Clew Bay, Pylaiella is always present, and forms in spring and summer large floating masses. Other frequent epiphytes are:-

Dictyosiphon foeniculaceus.

Ectocarpus siliculosus.

Ceramium rubrum.

C. Boergesenii.

E. tomentosus.

E. fasciculatus.

In late summer blue-green algae are much in evidence, Calothrix confervicola and Livularia atra occurring everywhere, often accompanied by 
large masses of Lymgbya majuscula. The more open parts of the bay show, with the exception of Dictyosiphon and Cyanophyceae, which are rare or absent, the same epiphytes (see also p. 25).

For the comparison of the present association with that of other countries, see p. 26.

\section{The Lichina Association (sheltered).}

Locally distributed on sheltered and semi-sheltered localities (Clew Bay, Achill Sound, Bellacragher Bay). See notes on p. 26.

\section{Porphyra Association (sheltered coasts).}

The growth of Porphyra found in many sheltered places, though not noted by previous writers, is very characteristic and worthy of record. It is found on two types of shore, viz. (1) gently sloping beaches of low rocks and stones, and (2) sandy bays where half-buried rocks are present. The growth oecurs more or less throughout the year, though it appears to be more abundant in spring and autumn than in summer. On both shores it is usually accompanied by various forms of Enteromorpha intestinalis and E. linza.

On beaches composed of stones and flat rocks the association usually fills up the gaps between Fucus. The latter is confined to the larger rocks, whilst Porphyra, which extends from below $F$. spiralis down to low-water mark, occupies the smaller stones and rocks, though it also occurs epiphytically on Fucus. The amount of grow th noted varied considerably on different accasions, as did also the size and form of the plants. In summer it is mostly confined to the lower levels, where it may form a distinct belt. This type of growth is well seen at Louisburgh (immediately east of the Bunowen River), also on the inner side of Bartraw and on Annagh Island, where wave-action is entirely alssent. Other parts of Clew Bay, which appeared equally suitable, were entirely levoiu of Porphyra. In the localities named a strong current runs along the shore, so that the conditions though quiet are not by any means stagnant, and this lact may in part explain the vigorous growth, and its absence elsewhere.

The second type of growth referred to, namely that on rocks in sandy bays, is somewhat remarkable, because the expanded membranaceous thalli have to endure the constant friction of the sand. In spite of this, however, a very vigorous and characteristic vegetation is found. The growth is most noticeable at the sides of low bare rocks or those crowned with a mass of Fucus. It may be seen thus in many spots in our area, and has been noticed in other parts of the British Isles. But in addition to this, Porphyra accurs on rocks unore or less hidden by sand, so that at first sight the growth might be taken for loose fronds that have become embedded. The plants are in reality 
attached to low-lying rocks, and are thus not only exposed to constant sandmovement, but are liable to be completely buried. On the other hand, with certain winds, nearly all the sand is removed by the tide; and the thalli lie on the bare rock. They are also liable to be covered by blown sand. Under average conditions it would appear that only a few inches at the base of the fronds are buried, and that the upper part remains free, lying flat on the damp ground: though one must assume that germination took place on rock. Associated with Porphyra are Enteromorpha spp., especially the large flat forms approaching $E$. linza. 'This plant oceurs in the damper positions, being most abundant in the lower part of the association, and reaching down to the sublittoral region. In August the Enteromorpha growth was in all cases much less than in May.

The zone formed by Porphyra on sheltered coasts is more extensive than in the open. In the sandy bays described above the plant escapes a certain amount of desiccation, and the result of this is seen in the fact that whilst on bare rocks it does not exceed the $F$. spiralis level (at all events during summer), on sand-covered rocks it frequently reaches Pelvetia. 'I'he lower limit also is further than that of the exposed association, for the plant is frequent at low-water mark, and occasionally extends well into the sub-littoral region.

The form assumed in sheltered localities is that of the divided and lanceolate type, var. laciniata J.Ag. 'I'his is specially well developed on damp rocks and on margins of pools. On drier rocks and with increased exposure there is a tendency for the fronds to become short and umbilicate. The sandrock form of the association is well seen at Mulranny, alsu between Old Head and Leckanvy, whilst a small patch exists in the bay on Clare Island. Though not noted, forma linearis probably exists in winter in the upper levels, as in exposed localities.

A similar vegetation of Porphyra would, judging by the localities described by Rosenvinge, appear to be widespread in Denmark ('09, p. 65).

Laurencia-Gigartina Association.

Fairly well developed in many parts of Clew Bay outside the islands. See p. 33 .

\section{Corallina-Lithothamnium Association.}

At times feebly developed in the more open parts of Clew Bay. See p. 39 .

\section{Corallina-Cladostephus Community.}

In company with the Laurencia community of sheltered coasts there often occurs a similar vegetation of short dense growth, but composed largely of 
Corallina, Gelidium, and Cladostephus, and having a tendency to approach the Rhodochorton floridulum association. The presence of Cladostephus spongiosus together with Corallina officinalis is very characteristic of this vegetation, and hence the name selected.

The community in question is essentially one of flat, sheltered rocks, aroiding the clean rocks and turbulent conditions eujoyed by Laurencia, but thriving with more slope and slightly more exposure than $R$. floridulum. It occupies the same bathjmetric range as Larrencia pinnatifida, and though capable of growing in the shallow sub-littoral region, it more often gives place to Gigartina or Laminaria. At Portlea it is intimately associated with Phodochorton, but the two communities are usually sharply defined, and distinguishable at once to the eye, as well as to the tread.

Though both Corallina and Cladostephus are rock-attached, a thin layer of sand is often found on the surface of the substratum. Corallina, under the conditions obtaining, is short and more or less erect, its stiff branches easily retaining sand and fine debris, so much so that the presence of blackened sand and particles of decayed matter is almost characteristic of the community. At the same time it is not truly psammophilous. A vegetation uf the same nature (though differing slightly floristically) has already been lescribed by me in connexion with the growth of Ulva, and the origin of the blackened sand is explained ('11, pp. 124 and 128).

The Corallina-Cladostephus sward is seldom so extensive as that of Rhodochurton floridulum, being patchy, and only occasionally forming broad belts. Gelidium centcutum is sometimes present in quantity, and $C$. squamata is common, especially in the more open regions. A very heavy epiphytic vegetation exists, of which Enteromorpha clathrata, Ulva, Leathesia, Comminm fubolligerum, and C. rubrum are the most abundant. Callithamnion Hookiti also is found in summer on Cladostephus. In addition to the above, a large number of sporelings occur. These succeed better on this vegetation than on Phodnchorton (where sporelings are exceedingly numerous); and though the plants do not attain their maximum size, they usually fruit, and are sufficiently large to give distinct patches of colour. Much Cladophore sericea and $C$. albida is present in spring; Ceramium rubrum in various forms is abundant in summer; whilst in October (1910) a form of Enteromorpha clathrata was very conspicuous. In summer Ulva also is present in great quantity, as has alrearly been pointed out (Cotton'11, p. 128), being saxicolous or epiphytic.

On Clare Island the association occurs on a small scale at Portlea and Kinnacorra; and on the mainland at many spots in the outer part of Clew Bay (Roonah, Louisburgh, Mulranny). A similar vegetation occurs on the 
south coast of England; and though not recorded from other countries, it probably exists, at all events, on the north of France.

\section{Rhodochorton floridulum Association.}

Small patches of this are occasionally found on rocky shores; but it is characteristic of the sand and low-rock series described later (p. 65).

\section{Sand-Pool Vegetation.}

Occasionally met with, but typically developed on sandy shores (see p.67).

\section{Cave Vegetation.}

The caves of sheltered coasts are dealt with on p. 46 .

(b) Sub-littoral Region.

Laminaria Association (sheltered).

The Laminaria vegetation of sheltered shores is fairly well developed. It is found in many parts of Clew Bay, in Bellacragher Bay, and in parts of Achill Sound. The characteristic species are $L$. saccharina and L. digitata, the latter being, as a rule, confined to localities where current is present. In the deeper and more open parts, $L$. Clonstoni exists; but with the appearance of this species $L$. saccharine drops out, and the association passes gradually into the exposed type.

Whilst on exposed coasts the Laminaria vegetation is typically in belts, on sheltered cuasts it is commonly discontinuous, and occurs rather in plots. This is mainly owing to the scattered nature of the anchorage. It is found wherever rocks or large stones occur; and the amount is determined by the extent of the stony area. In Clew Bay, the hard bottom is found in three kinds of ground, each of which supports a different type of Laminaria vegetation. As the latter are determined by definite ecological conditions, and as, in Clew Bay, they scarcely overlap, it is reasonable to regard them as three sub-associations.

The sub-association of Laminaria saccharina (most often var. latissima) occurs in the inner part of the bay, where the conditions are quiet and the current weak. The fronds are long and very broad-in extreme cases up to a yard across. Occasionally the association is pure (except for small species forming the undergrowth); but as a rule other algae intrude, such as Cystoseiva granulata and Hulidrys siliquosa. Rarely the association merges into the Zostera beds. The second sub-association is characteristic of ground 
where there is a strong eurrent, and is found typically in the channels of 3 to 5 fathoms between the outer islands. It consists entirely of $L$. digitrita. The bottom is scoured by the tide; but the larger stones and blocks of rock support a vigorous growth. The plants are remarkably strong, and in the deeper parts the fronds often attain a great length. Epiphytic species are few ; but in such localities the peculiar plant known as Rhodymenia palmat var. serniensis is occasionally met with. The third type of Laminaria vegetation, characterized by the presence of $L$. Cloustoni in addition to $L$. digitata, is found only outside the islands. It extends over large areas in about 7 fathoms, and passes gradually into the exposed vegetation that occurs further ont.

Representatives of these same sub-associations are found elsewhere. $L$. digitata is abundant near the south entrance of Achill Sound; and in the quiet waters of Bellacragher Bay a distinet $L$. saccharina vegetation exists, which in several places extends to the shore. In other countries, the sheltered type of Laminaria vegetation has not received much attention. In the Faeröes it is well developed, and shows similar variations to those in Clew Bay; though with floristic differences. $L$. faeroensis takes the place of $L$. succharina in quiet bays, and $L$. Cloustoni forms the vegetation of channels. The Laminaria zune described by .Junbin (09) includes patches of $L$. sacharina attached to stones on a soft bottom, which obviously correspond to the sub-association of that species dealt with above.

\section{Encrusting Alga Vegetation.}

Occasionally found, but more often on exposed coasts (see p. 50 ).

\section{II.-Sand and Sandy-mud Formation.}

The present formation is characterized by a large quantity of movable sand or sandy-mud, in which the vegetation is liable to be partially or completely embedded. In its extreme form, the shore consists entirely of this matrix, the algae being immersed in sand, forming, in fact, a sand-binding conmunity. But the sand formation passes by transitions into the rock-formation on the one side, and to mud-flats on the other.

As an example of a sand-binder we may take Microcoleus, whilst Vaucheria Thuretii supplies an instance of a plant that fixes sandy-mud. Broth form extensive associations. Rhizoclonium riparium also may under certain conditions form a surface-covering on a shore of pure sand. In the majority of sand-beaches, however, all vegetation is absent and only begins to show when solid ground is reached. Where low half-buried rocks occur a 
psammophilous vegetation is found, of which Rhotochorton is a good example. With extreme shelter, this can form a mossy carpet on pure sand; but as a rule it is only found on sand-covered rocks, or on small intervening sandspaces. The alga is probably in the first instance attached to rock, but as the plants grow they form adventitious rhizoids and accumulate sand. Being saxicolous, Rhodochorton extends to rocky shores, where sand is scarce or even absent. As an association, however, it is only found where this material is plentiful. Several other psammophilous species accompany Rhodochorton.

The Corallina-Cladostephus community represents the last stage in the transition from sand to rock. Though frequent on sandy shores, a bed of rock is essential for its growth, hence it has been dealt with under the rockyshore formation. The sand-pool vegetation is, on the other hand, described in the present section, as the characteristic species, though attached to rock, are markenly psammophilous. The sub-littoral associations call for no special comment, except that the last three are not strictly psammophilous, though in our district they are confined to sandy areas. They are placed under this heading for convenience, and therefore provisionally.

The associations and communities recognized in the sand and sandy-mud formation are as follows:-

(a) Littoral Region.

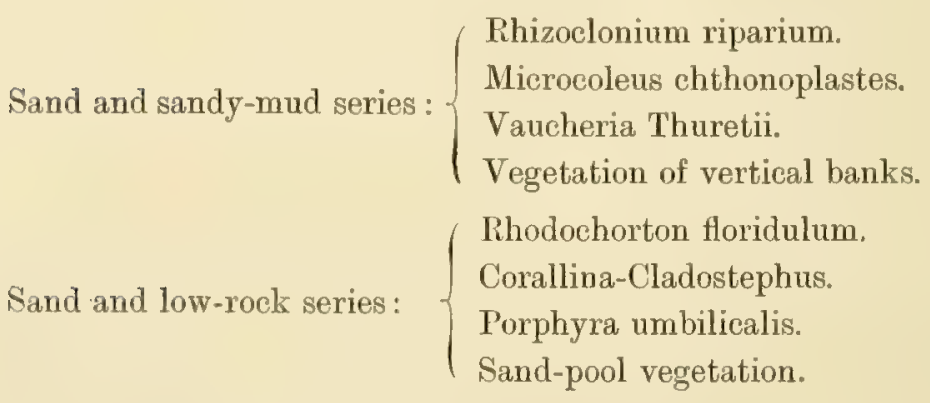

(b) Sub-littoral Region.

Rhodochorton floridulum.

Zostera marma.

Fruticulose Lithothamnium.

Pebble-attached association.

Encrusting algae.

Channel-vegetation. 
(a) Littoral Region.

Rhizaclonium riparium community.

The only community found on pure sand in our area is that of Rhizoclonium, though for this also a small amount of binding material is advantageous. The regetation is found immediately below high-water line, and is occasionally rery conspicuons, specially in spring and summer. At Mulranny, where the shore is unusually flat, Rhizoclonium covers extensive areas, patches an acre in extent having been noted. ${ }^{1}$

The underlying sand (or sandy-mud) is for the most part firm, often bound together by Microcoleus, but in other spots it is loose and apt to become dry. In either case Rhizoclonium lies as a loose covering, thus feeling the effect of wind and tide, often being more or less buried. In some localities the upper part of the association is during neap-tides not wetted at all, and in this way differ's from the somewhat similar filamentous vegetation which lies on wet mud, e.g. on the Taucheria Thuretii association in Achill Sound (p. 64). Rhizoctonium riparinm is usually a pure dominant, but amongst it (especially in the damper parts?) occur Enteromorpha prolifera, E. clathrata var, and Cladophora fracta. The blue-green species, so common in the corresponding association on the salt-marsh, are absent.

A very similar type of growth to that described above has been noted in Poole Harbour, and on a small scale near the mouth of the River Bann. (See also salt-marsh formation, p. 79.)

\section{Microcoleus chthonoplastes association.}

Of the sand-and mud-binding algae one of the most important is Microcoleus chthonoplastes, a microscopic species of world-wide distribution. The plants are often completely hidden in the substratum; but their presence can be detected by the way in which the soil holds together, and peels off in crusts, when lifted up. Though Microcoleus has not been previously recorded as forming an association as such, the plant-community has as a fact been long known, and for a description one cannot do better than quote Gomont's note in his revision of the Oscillarieae ( 09, p. 92) :-

"Le Microcoleus chthonoplastes se rencontre quelquefois à l'état de filaments isolés mélangés à d'autres Algues, ... mais il occupe aussi à lui seul de vastes étendues sur les côtes marécageuses ou sablonneuses. Il joue un rôle des plus utiles dans l'exploitation des marais salants en recouvrant le fónd des bassins ou oeillets d'un tapis compact qui permet d'enlever les cristaux

I The flatness of the shore at this spot may be judged from the fact that the Pelvetia zone, which is only about 1 foot deep, is in places over 80 yaxds wide. 
de sel sans mélange de vase. En cet état il forme des assises diversement colorées, accumulées sur une épaisseur parfois considérable et dont les supérieures, qui sont les seules vivantes, peuvent être détachées par larges plaques et roulées comme des morceaux de drap. Ce végétal mérite done completement le nom de chthonoplastes (constructeur du sol) qui lui a été donné par les premiers observateurs."

In Clew Bay the Microcoleus association was usually found where there was a certain anount of mud. It occurs in large patches at Mulranny and also in the Belclare neighbourhood. In the small bay to the north-west of Achill Bridge it forms a broad band just below high-water line, binding the upper layer of mud into a firm sheet. It was also noted in several localities in fairly pure sand, but only as covering small areas.

Various other blue-green algae enter into the composition of the association, notably :-

In upper parts:

Lyngbya aestuarii.

L. lutea.

Microcoleus tenuis.
In lower parts:

Vaucheria Thuretii.

Rhizoclonium riparium.

Enteromorpha torta.

Vaucheria Thuretii Association.

This vegetation takes us further still from the pure sand, being found only where there is a considerable proportion of mud. Future work will probably show that it should be regarded as an association in the mud-formation. $V$. Thuretii forms a dense mossy growth embedded in the matrix, and appears to cover very extensive areas. Several samples were taken both from Clew Bay and from the muddy inlets north of the bridge at Achill Sound; and in each case the mossy tuft consisted of this species, often in beautiful fruiting condition, and practically pure. The growth is always immersed, the tips of the filaments alone showing, thus differing markedly from $V$. coronate, which forms a clean velvety growth. Felts compused of Rhizoclonium, Chaetomorpha and Cladophora fracta often lie on top of the Vaucheria, and these, in many cases, appear to be attached, and not merely drifted fragments; so that it is possible that careful study would reveal definite societies of other species amongst the general vegetation of Vaucheria.

'The vertical range of $V$. Thuretii is determined by the extent of the sandy mud. It flourishes in the lower part of the littoral region, and probably descends to low-water mark. Its upper limit is usually immediately below F. spiralis, but whether this was due to the lack of sufficient mud or to other causes in addition (such as long exposure to the air) was not ascertained. On 
the banks of rivers and where the water is brackish a zone of $V$. corronata is the characteristic vegetation near high-water line, but in Achill Sound that species is absent, and Microcoleus chthonoplastes is the dominant alga.

\section{Vegetation of Vertical Banks.}

Vertical peat-banks, abutting on the shores of Clew Bay and Achill, exhibit a similar vegetation to that described later for the salt-marsh formation (see p. 82).

\section{Rhodochorton floridulum Association.}

This association, though not hitherto described, is very distinct and of common occurrence in many parts of the British Isles, including the Clare Island district. It is characteristic of sandy shores where rocks are present, and is found on moderately open as well as sheltered coasts. Rhodochorton $\vec{f}(m)$ id $u l u m$ is the mostimportant of a group of finely branched, upright-growing algae, which retain quantities of sand, if they do not actually bind it together. Other members of the group are:-
Cladophora areta,
Ceramium strictum,
Polysiphonia fibrata,
C. ciliatum.

In suitable localities the association extends from the Fucus spiratis belt down to low-water line, but it also descends into the sub-littoral region, being found abundantly letween the islands in Clew Bay. It prefers flat or slightly sloping shores; on steep shores the sand is washed away, and the plant is practically absent. Being of small size, Rhodochorton cannot fix sand on the same scale as phanerogamic plants, nor does it occur on sand apart from rocks" except in very sheltered areas, or where it is submerged and beyond the effect of rough water. It is, however, capable of covering flat or sloping rocks with a dense mossy growth; and of carpeting the intervening sand-spaces so that they completely resist normal wave-action. In its young state the plant is probably attached to rock, but as growth proceeds, sand collects, and the abundant production of rhizoidal filaments helps to retain it. The growth forms either pads which may measure a foot or so across, or vast sheets more or less interrupted, but extending at times over a very wide area. When wellgrown, the Rhodochorton sward is about $3 \mathrm{~cm}$. high; but in favoured spots pads up to $6 \mathrm{~cm}$. have been met with. Though sometimes exposed to the full light, especially on the lower part of the shore, Rhodochorton grows best with partial shade. But even when exposed to light it is the ends of the branches only that feel the full effect of sun and air, as the base of the plant is covered with sand. 
Of the other species entering into the association Polysiphonia fibrata, Ceramium strictum, C. citiatum form conspicuous patches in spring and summer, their tufts of rhizoids growing down into the sward, aud attaching themselves to the sand-grains. C. ciliatum is found more or less all the year round, and is of a shorter and clenser habit than when growing in pools. In spring the association often assumes a bright green colour due to the presence of Cladophora arctu. This species retains the sand well by means of hooked branches and rhizoids which grow downwards from the main shoots. It occurs not only within the Rhodochorton vegetation, but outside it, often forming on its flanks large unmixed patches. A dwarf form of Splucelaria cirrhosa is also frequent, but, because of its small size, is apt to be overlooked. Though a filamentous species, it is distinct from the others, being attached by a basal disk, and not by rhizoids. In late summer, especially in the more sheltered localities, Rhodochorton is much discoloured by the presence of cyanophyceous epiphytes. Of these Caluthrix confervicola is the most common, being at times so abundant as to create large black patches. Aphanotheca pallida is also frequent. On the margins, where the association joins the CorallinaCladostephus vegetation, many other algae appear, and it is probable that the borders of the two communities are in a continual state of change.

Young plants of Ulva Lactuca are at times present in great quantity, especially in spring, but this species is in no way a sand-binder, possessing only a foliose thallus and a basal disk. In the same way we may dismiss many other intruders, the Rholochorton sward being, in fact, a general nursery ground, the sporelings succeeding each other in regular sequence as the seasons come round.

With regard to distribution, the present community is probably very widely spread in the British Isles. Rhodochorton floridulum is one of the few species that form extensive associations on the flat sandy shores of Sussex; and it has been found growing in the same way in Dorset and Devon. Harvey states that at Kilkee (Co. Clare) "it often carpets large spaces on the rocks"; and Ralfs writes in a similar strain as to the plant at Land's End (in litt.). It is also abundant on the shores of Belfast Lough. With regard to the Survey area, the association is found at Portlea on Clare Island (rocks giving the necessary shelter;, and on a small scale in several other bays, where protection is afforded by a heavy growth of Fucus. On the mainland, where for the most part no special protection is required, it is very widely spread, probably coming next to that of the Fucaceae in the amount of area covered. According to Harvey the plant is washed ashore in quantity during autumn; and the hemispherical cushions are collected (under the name of "figs") for use as manure (Phyc. Brit.). 
Corallina-Cladostephus Community.

This vegetation is frequently very well developed on sandy shores where low rocks are present (e.g., Old Head). It retains a certain amount of sand, but is usually found on raised or sloping rocks where the quantities deposited are small. The community clearly forms a comnecting link between the sandand rock-formations; but as both the species composing it are distinctly saxicolous, and do not form rhizoids, it is regarded as belonging to the latter, and is dealt with on p. 58 .

The Porphyra umbilicalis Community.

'Though attached only by a basal disk, and clearly belonging to the rockyshore formation, $P$. umbilicalis var. laciniate is frequently found, fringing the sides of half-buried rocks, on sandy beaches. Its growth in this habitat is described on p. 57.

\section{Vegetation of Sand-Pools.}

A very interesting psammophilous flora occurs in pools amongst low rocks on sandy shores. The plants are not small and filamentous, such as Rho. dochorton or Vaucheria (pp. 65 and 64), but large and bushy; hence, though partially embedded in sand, they are invariably fixed to underlying rock. Polyides and Gracilaria may be taken as typical examples; but some six or eight other species occur, all being sand-loving plants, and found as a rule in the sub-littoral region. When, as is often the case, ordinary rock-pools are absent, the constancy of this sand-pool vegetation is very manifest.

Algae which thrive under such conditions have, as would be expected, much branched thalli of erect habit. The frouds are more or less terete, and in many cases tough. But other forms occur, especially where the amount of sand is not excessive. Sand-pools are found at Old Head, and between that spot and Leckanvy; also to a certain extent near Mulranny. The typical flora is as follows:-

Polyides rotundus, $c$.

Ahnfeltia plicata, $c$.

Gracilaria confervoides, $c$.

Polysiphonia elongata, $c$.

P. atro-rubescens, $c$.

Furcellaria fastigiata.
Gymnogongrus Griffithsiana, $r$.

Gelidium crinale, $r$.

Cladostephus spongiosus.

Corallina officinalis.

Rhodochorton floridulum.

The last three are not characteristic of this vegetation only; but they are exceedingly common if the sand-layer is not thick, and, as shown above, they form part of the littoral flora of the shore in question. The species of 
Gymnogongrus and Gelidium were, however, not found outside sand-pools. Where the sides are steep, ordinary saxicolous species naturally occur; but as a rule the sides are shelving and the pools shallow. When fresh water exudes between the rocks, the Rhodophyceae are replaced by Chlorophyceae-i.e., Chaetomorpha aerea, Enteromorpha intestinalis, Cladophora sericea, $C$. rupestris, and Ulva Lactuca; Gracilaria, however, usually remains, being able to withstand a considerable quantity of fresh water.

Where the sand-layer is very thin a number of other species are found, and being characteristic of sandy shores, the most usual amongst them are listed below :-

Ulva Lactuca (very thick form).

Enteromorpha Linza.

Monostroma Grevillei (epiphytic).

Scytosiphon lomentarius.

Punctaria latifolia.

Chordaria flagelliformis.

Eudesme virescens.

Leathesia difformis.

Chorda filum.

Cystoseira granulata.

Halidrys siliquosa.

Dictyota dichot, var. intricata.
Porphyra umb. laciniata.

Helminthora divaricata (on Polyides).

Gelidium spp.

Chondrus crispus (broad form).

Gymnogongrus norvegicus ( $r$ ).

Chylocladia kaliformis.

Laurencia pinnatifida.

L. hybrida.

Polysiphonia nigrescens.

Spermothamnion Turnexi(epiphytic).

Dumontia filiformis.

Lithophyllum incrustans.

(b) Sub-littoral Region.

Rhodochorton floridulum Association.

As before mentioned, this psammophilous species descends into the sub-littoral region, covering large areas where the bottom is flat and very sheltered, as in the inner part of Clew Bay. The association apparently exists in certain spots as an ummixed growth; but as a rule it is more or less interspersed amongst Lithothamnium or other algae (see p. 65).

\section{Zostera Association.}

The soft bottom of the inner part of Clew Bay is admirably suited to the growth of Zostera, and in the muddy parts especially, extensive beds are foumd. The characteristic algal epiphytes are also well-developed, being most marked in spring and early summer.

Ostenfeld in his report on Zostera ('08) points out that, as a general rule, 
the size of the plant is more dependent on the nature of the bottom than on the depth in which it grows. He shows that the form with short, narrow leaves is found on firm sand, and that the long, broad-leafed form is characteristic of soft mud, rich in food substances. A slight difference between the algal vegetation of the sand and mud Zostera was observed in Clew Bay, but not with sufficient care to warrant comment, except to note that the latter proved the most productive in the way of algae.

In spring, masses of Ectocarpi occur, together with innumerable tufts of Cladophora lanosa; whilst in summer and autumn species of Bangia and Chantransia are more abundant. Ascocyctus orbicularis is almost always present, being noted in quantity in spring, summer, and autumn. At the margins of the Zostern-meadows, and in spots where largest ones exist other plants, such as Halidrys, Laminaria saccharina, and Cystoseira granulata, are met with; and the association then tends to approach that which Ostenfeld has termed the "mixed Zostera vegetation" (1.c., p. 33). Of the larger epiphytes the following are usually frequent in their respective seasons:-

Cladophora lanosa.

Castagnea Zosterae.

Punctaria tenuissima.

Desmotrichum undulatum.

Ectocarpus confervoides.

E. siliculosus.

E. $s p$.

Litosiphon pusillus.
Myriotricha densa.

Scytosiphon lom, var. zostericola.

Laurencia obtusa var, crucifera.

Polysiphonia violacea.

Ceramium strictum.

Giraudia sphacelarioides, $r$.

Leptonema fasciculatum, $r$.

Mesogloia Ianosa, $r$.

Whilst among microscopic species may be mentioned:-

Calothrix confervicola.

Chantransia virgatula.

C. Thuretii.

Ascocyclus orbicularis.

Rhodophysema Georgii.
Melobesia farinosa.

Rivularia atra.

Isactis plana, $r$.

Exythrotrichia Bertholdii, $r$.

\section{The Fruticulose Lithothamnium Association.}

Probably no group of seaweeds is more generally recognized as forming extensive colonies or associations than the Lithothamnia. Submerged beds, often known as "coral-banks," occur in the arctic, temperate and tropical regions. In the latter they are frequently exposed at low water, and play 
an important part in the formation of coral reefs. But notwithstanding the many references, both systematic and biological, to this type of vegetation, it is not by any means easy to compare the Lithothamnium flora of one country with that of another. This is owing to the deceptive nature of morphological characters, and to the many erronenus determinations in the past. Foslie has left reliable records for recent years, and the anatomical classification elaborated by Dr. Lemoine promises more success for the future.

Between the outer islands of Clew Bay areas of Lithothamnium calcareum ("coral-banks") are common. They are found on a soft but firm bottom, consisting usually of stones and shells on sand, though occasionally Lithothamnium may be dredged where there is a thin layer of mud. The usual depth in which the banks occur is $1-5$ fathoms, and here and there the plants may be gathered by hand during the lowest tides. The association is composed of the following species:-

Iithothamnium calcareum, dom.

Lithophyllum fasciculatum, locally sub-dom.

L. incrustans.

L. incrustans var. subdichotomum, rare.

Lithothamnium norvegicum, rare.

In many places $L$. calcarcum forms a pure growth extending over a considerable area, but in others it is mixed with $L$. fasciculatum, and sometimes all four species occur mixed together. A characteristic growth of epiphytes accompanies the regetation, of which Polysiphonia subulifera, Pterosiphonia paresitica, Aglaosonia reptans, Spacelariu cirhose, Rhodochorton floridulum, and Gelidium sp. are the most constant. Dietyota, Chylocladia kaliformis, and Laurencia obtusa are also abundant in summer.

With trivial variations this is the type of fruticulose Lithothamnium vegetation found throughout Clew Bay. It presents one remarkable floristic feature, namely, the presence of $t$. fasciculatum, a species which is only known from the west of Ireland. Another interesting plant is $L$. incrustans, var. subrichotomum, an alga which was formerly regarded as $L$. dentatum, but shown by Dr. Lemoine in the present report to be a detached and rolling form of the common species, $L$. incrustans.

Other Lithothamnium banks in Ireland and Great Britain.-It was of interest to find that the Clew Bay association agreed exactly in its composition with that which had been described for Roundstone. The latter district is the original station for $L$. fasciculatum; and Foslie, when working out the European Lithothamnia, paid a special visit to the locality and 
published an account of his trip ('99). He found $L$. fasciculatum still plentiful, as it was also in September, 1911. The dominance of $L$. calcareum in both Roundstone and Clew Bay is normal for the British Isles.

The remarkable "coral beaches" at Mannin Bay and Ballyconneely Bay (Co. Galway) are due to the presence of extensive Lithothamnium associations in the neighbourhood. When driving from Clifden to Roundstone in September, 1911, the former spot was examined; but time did not permit of exploration by dredging. It was evident, however, that the material washed up is $L$. calcareum, and that the beach, a fairly wide one, is composed almost entirely of broken particles of this species. The photographs on Plate IV, kindly taken by Dr. G. H. Pethybridge, show two views of the beaches in Mannin Bay. A few low rocks occur in part of the bay as shown in the lower illustration, but elsewhere there are stretches of pure "coral sand." The greater part of the sand is composed of small particles (see Plate V, fig. 1); but at high-water line and in certain other places coarser pieces and knolls accumulate, with a certain quantity of broken shells. Dr. Pethybridge informs me that at low-water mark the particles are exceedingly fine and resemble ordinary sand; but it is probable that they have the same origin. 'I'he Lithothamnium fronds are completely bleached, and the beach is thus dazzlingly white in the sun. Though the coral sand is carted for use as manure, fresh supplies are constantly washed up, so that it is evident that the bank outside is extensive. A similar beach is said to exist in Bantry Pay. ${ }^{1}$

In the British Isles $L$. calcareum is certainly the dominant fruticulose species, beils being known from several localities (Studland and Falnouth in the south of England, and Bute in Scotland), and under certain conditions it is washed ashore in quantities. A fine bed in 14 fathoms was once dredged by me off Fowey (Cornwall). Another species, L. racemus, appears to exist as an association at Falmouth, since it is washed ashore in plenty; but this is the only station for the plant in England, and records of Lithothamnium banks in England or France formed by species other than $L$. calcareum require verification.

Comparison with other countries.-L. culcareum is also frequent in France. It is abundant in Normandy, and in Brittany as far south as Croisic. Lemoine ("11) states that it is known from Denmark, Portugal, Naples, Morocco, and Algeria. In all these localities it probably oceurs in associations similar to

1 Several other remarkable beaches occur in the west of Ireland. A shore consisting exclusively of broken shells is found at Knockboy (Co. Galway), which, like the coral-sand beaches, is exploited for manure (Johnson and Hensman, '99); whilst Dog's Bay, near Ruundstone, is famous for its beautiful sands, composed almost entirely (up to 90 per cent.) of Foraminifera. 
these found in the British Isles. At Morlaix and Concarneau there is "coral sand" or "Mäerl," and, as in Ireland, this is used for manure. Lemoine ('10) has also published a detailed account of the biology of the plant. She notes that at Concarneau the bottom of the bay is practically covered with L. calcareum, and fragments of living fronds are continually cast up by the waves. Several "coral beaches" occur on the islands of the Glenan Archipelago, but there, as at Mamnin Bay, the fragments washed ashore are mostly dead.

In the Arctic seas, Kjellmann writes of large areas, in 10 to 20 fathoms, covered with Lithothamnia, of which L. glaciale and L. soriferum are abundant. At Mussel Bay in Spitzbergen, L. glaciale is said to cover the bottom to an extent of 4 to 5 square miles; whilst off the north of Norway and on the coast of Iceland, L. Ungeri is abundant. In the former country banks of $L$. norvegicum also occur. The association is represented in Greenland by L. Ungeri. In the south of Norway the floristic features are more in agreement with those of Britain, and L. calcareum becomes prominent. An association composed largely of this species has been described by Gran for Kristianiafiord ('93).

Reference must be made (though it is outside our usual circle of comparison) to Madame Weber van Bosse's account of the Lithothamnia of the "Siboga" Expedition ('04). A very luxuriant vegetation exists in the shallows and reefs of the Malay Archipelago, and several communities on different types of ground are referred to. A description is given of a locality where the Lithothamnium knolls are rolled backwards and forwards between the islands by the tidal current, whilst in other parts of the same channel they are heaped up in lanks. Two photographs are reproduced of an extensive bank of L. emibescens var. Haingsisiana, which Madame Weber describes as being "covered as far as the eye can reach by the pretty, beautifully pink-coloured knolls, which are heaped so close together, that while walking one crushes them continually, making a peculiar noise as of broken china" (l.c., p. 5).

Geological Importance.-In localities where masses of Lithothamnium accumulate on the sea-bottom, these algae play an important part in rockformation, and masses of limestone containing well-preserved Lithothamnia occur in various geological strata. Structureless limestone also may be derived from the same source, for Walther, working at Naples, showed that the structure of recent Lithothamnium nodules is gradually obliterated by the action of percolating water. The literature on the subject is scattered; but Seward's paper ('94) gives a general summary with a full bibliography; and a brief but up-to-date account has just been published by Lemoine ('11 b). 
The Pelble-attached Association of Quiet Bays.

This assoriation represents a definite type of sub-littoral vegetation, which is found on a soft bottom strewn with stones and pebbles. A very large number of species go to form it, and they are for the most part characterized by finely divided bushy fronds, though heavier and less bushy plants are found on the larger stones and on the occasional pieces of rock. In some localities almost every stone down to the smallest pebble bears a tuit of one or more algae. The latter consist of members of the Green, Brown, and Red groups; and, though they vary considerably in different localities, the mixture of colour is a marked feature and suggests comparison with Kjellmann's "Bunte Formation." But both the constituents of that association, and the depth at which it occurs, are different from those here described. The present vegetation corresponds rather to Börgesen's Stictyosiphon association and to Boye's Dictyosiphon-Spermatochnus-Corallina formation, though Dictyosiphon is not always present. The species are annual or short-lived, which in part accounts for the varied aspect presented during the season.

The association extends from just above low-water mark down into 3 or \pm fathoms. Its shallower regions may be studied in detail by wading at spring tides, when the bushy froncis of Polysiphonia, Cladophora, Spermatochnus, Dictyosiphon, etc., may be examined in situ. Dredging in deeper water shows a very similar type of growth, though some species disappear and others become more abundant. The colour of the red species improves with increased depth. The association, which reaches its maximum development in May, is well seen in many of the inner parts of Clew Bay, and has been studied specially on the west side of Annagh Island, and, in a slightly morlified form, in Bellacragher Bay. In brackish localities an increase of Chlorophyceae is apparent.

As it pecurs in Clew Bay the prineipal species are as follows :-

(a) In spring -

Enteromorpha clathrata.

Cladophora Rudolphiana.

Striaria attenuata.

Stictyosiphon subarticulatus.

Dictyotosiphon foeniculacea.

Ectocarpus siliculosus.

Pylaiella littoralis.

Cystoclonium purpurascens.

Delesseria hypoglossum.

K.1.A. PROC., VOL. XXX1.
Lomentaria clavellosa.

Nitophyllum punctatum.

Polysiphonia urceolata.

$P$. elongata.

P. nigrescens.

P. atro-rubescens.

Ceramium rubrum.

Griffithsia corallina. 
(b) In summer Striaria, Dictyosiphun, Delesseria, and Griffithsia largely disappear, but the other species remain; and in addition we find:-

Cladophora rectangularis.

Spermatochnus paradoxus.

Castagnea virescens (shallow water).

Dictyota dichotoma.
Polysiphonia subulifera.

P. violacea.

P. fibrillosa.

Brongniartella byssoides.

Ceramium spp.

As autumn advances one species after another becomes detached and disappears, though Dictyosiphon, Ectucarpus, and Polysiphonir nigrescens remain. A day's dredging in February showed that most of the spring species had started growth; but the vegetation on the whole was very scanty compared with that of spring and summer. It should be noted that a few of the species above listed may be largely epiphytic on the uthers, and that in summer the upper part of the association is very poor.

Very many other algae, both littoral and sub-littoral, enter into this vegetation. Several of these are characteristic of other associations, e.g. Gracilaria, Polyides, and Rhodochorton florihulum. C'allithamnia likewise are very plentiful, and the encrusting alga association is often found as an undergrowth.

\section{Encrusting Alga Association (sheltered).}

In spite of unwillingness to change names, a new term is introduced here. The Lithoderma formation described hy Kjellmam has been recorded by other observers; but the difficulty of determining encrusting species makes it often impossible to be certain if Lithoderma is really dominant, or whether other algae of similar appearance are not equally common. With regard to Clew Bay, it is not certain that Lithoderma is even present; though, judging from sterile specimens, it is probably abundant. A wider and more general term has therefore been selected.

The association is found on a soft bottom overlaid with shells and flat stones, which, instearl of supporting a bushy vegetation like the last-named, are practically coverel with encrusting algae. Of these, the first four in the following list are conspicuous and easy to recognize; the remainder are probably common, though not so readily detected:-

Ralfsia rerucosa.

Aglaozonia reptans.

Cruoriella Dubyi.

Lithophyllum incrustans.

Ralfsia clavata, $f$.

Lithoderma fastiscens?, $f$.
Petroderma maculiforme, $r$.

Lithothamnium hapalidioides, $f$.

L. Lenormandi, var. sublaevis, $/$.

Melobesia zonalis, $r$.

Peyssonuelia sp.s, 2 . 
The above vegetation characterizes much of the inner part of Clew Bay. At times it forms an undergrowth to the pebble-attached association; but as a rule it appears to exist as a separate community, except for a certain admixture of Rhodochorton floridulum and Sphacelaria cirrhosa. In winter Cordylecladia erecte is also plentiful. The February visit was most useful in obtaining fruiting material, but even then many of the Brown encrusting plants proved sterile. A January visit would perhaps have been more productive. Outside the islands the species mentioned mostly disappear, the rocks and stones being clothed with plants which belong rather to the exposed Lithothamnium association (e.g., L. laevigatum and L. compactum).

It is difficult to compare the Clew Bay growth with that of other localities, especially with regard to the relative abundance of the different algae, but it appears to be richer in species than any of the Lithoderma associations hitherto described (Kjellmann, '78, Börgesen, '05, Kylin, '07). In England much dredging has been done by various workers, and Plymouth Sound, which is as sheltered as Clew Bay, has been well explored. The records, however, are poor, and there is no means of satisfactorily comparing the vegetation. It is interesting to note that Harvey dredged Peyssomnelia abundantly in Birturbuy Bay, whereas in Clew Bay Cruoriella Dubyi is by far the most frequent species.

\section{Channel Vegetation.}

On each visit a record was kept of the species collected in the shallow channels at Achill Sound. 'Though far from exhaustive, the lists serve to indicate the most conspicuous algae during the different seasons of the year, and since no record of the seasonal development of this type of vegetation exists, they appear to be worthy of publication. Kuckuck ('97) briefly describes the seasonal variation in Heligoland; but his paper deals with an open shore. It will be noted that the flora of the channels resembles that of the pebble-attached association of quiet bays - a fact which is not surprising, since the general surroundings are similar, and in both cases the plants are attached to stones on sand. In the channels, however, there is rapid current, whereas in the bays the water is slack. 'The accompanying table comprises lists of the four seasons of the year:- 


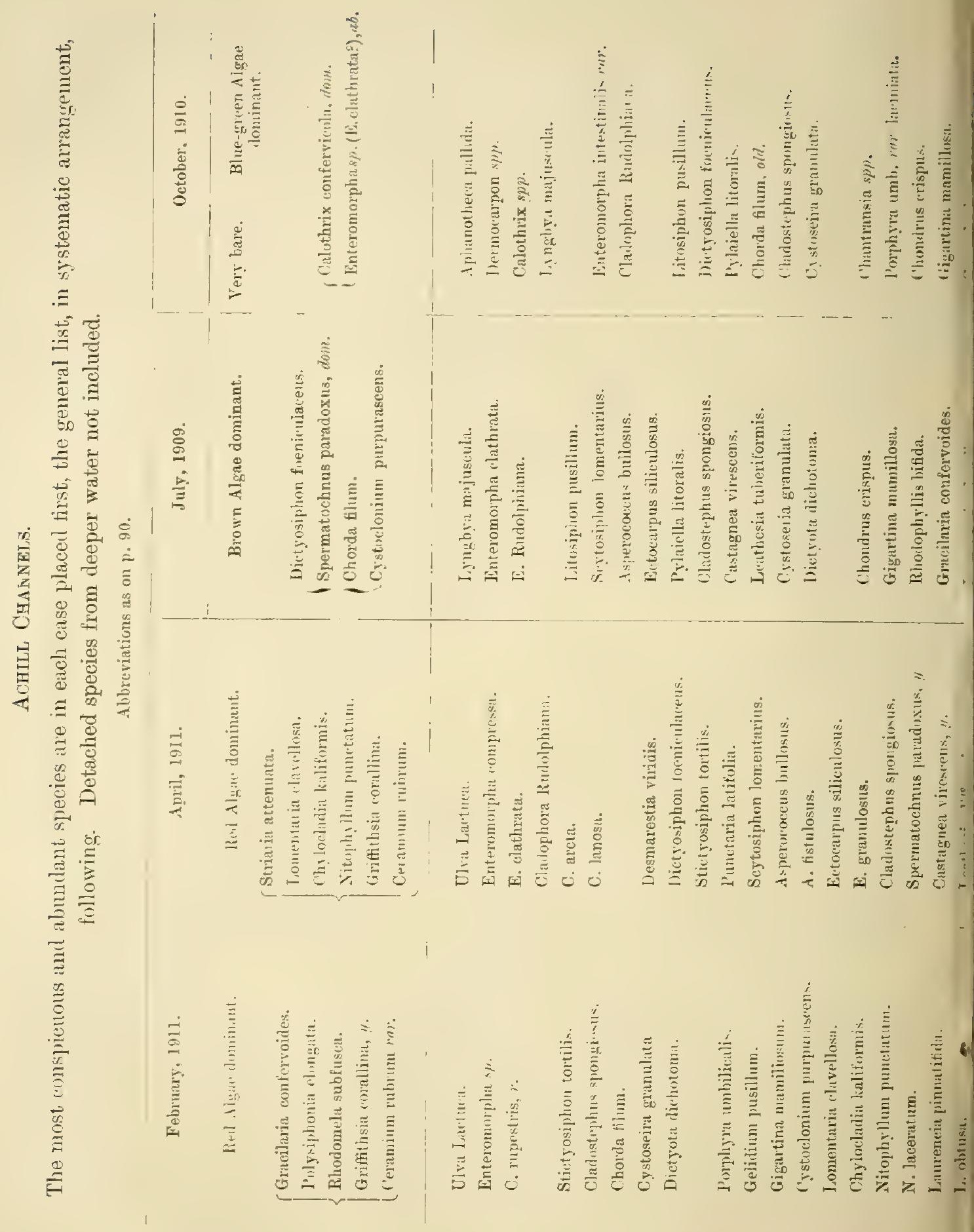




\section{III.-The Salt-Marsh Formation.}

The conditions obtaining on the salt-marsh resemble those of the sand-, rather than the rock-formation; but they differ in several important particulars. In the first place, the salt-marsh formation is situated above the level of high-water at ordinary neap-tides; and in the second, the substratum contains more or less humus consisting of mud or alluvial deposits, and in the Clare Island area peat is frequent. By reason of its bathymetric position, the marsh is only flooded at spring-tides, and hence the algal vegetation instead of being moistened daily by the tide is liable to desiccation on the one hand, and to prolonged soakings of fresh-water in the form of rain on the other. Further, there is continual competition with finwering-plants. As a result of the edaphic conditions, we find that the algae are not attached by a basal disk as in saxicolous plants, nor are they completely buried as is the case with many psammophilous species; but they either lie loosely on the substratum or are apparently rooted in the ground, after the manner of flowering-plants. The lack of fully saline conditions shows itself in the predominance of brackish species, green and blue-green algae being abundant. The salt-marsh often passes by easy transitions to sandy shores, mud-flats, or to the banks of rivers.

From the floristic standpoint, the algae of the salt-marsh are generally uninteresting; but among the Fucaceae remarkable forms occur, several of which have long taxed the energies of systematists; but with increased attention to ecolngical considerations their elucidation appears more hopeful. The Florideae are represented (amongst macroscopic forms at all events) by two species only, viz., Catenella Opuntia and Bostrychice scorpioides. Cyanophyceae are abundant; and as far as filamentous genera are concerned, they fall into fairly well-marked species; the chroococcaceous series have not been specially examined. Phoeophyceae are often conspicuous, and figure largely as regards bulk, being represented almost entirely by members of the Fucaceae. The latter vary widely in different localities, and are often of considerable interest. The Chlorophyceae are well represented; and, as is usual under brackish conditions, they are often difficult to determine. Rhizoclonium, Chaetomorpha, and the smaller species of Enteromorpha are abundant, and show much variation in form. These green algae are doubtless largely modified by the peculiar conditions of the salt-marsh-a result which is not surprising, when one considers the profound modifications amongst the less plastic group of the Fucaceae. The variation displayed by Enteromorpha intestinalis on flat shores when fresh-water is present is most extraordinary. With regard to edaphic conditions, a certain amount of variety will be found 
on the same marsh. In the Clew Bay district the substratum consists of peat, or of a loamy soil derived from the boulder-clay; patches of mud also occur. With the exception of the dwarf Fucus, most of the algae associations described below occur on each of these types of ground. The mud-flora is the most distinct, and where soft it differs markedly; but otherwise the nature of the substratum does not appear to exert a great influence in this particular district. With a detailed study certain differences would doubtless be detected. The vegetation of the mud-patches of the salt-marsh approaches on the one hand that of the mul-banks of the tidal streams, and on the other that of the mud-flats below high-water mark. Several of the salt-marsh species lie on the ground, or on other vegetation ; but Bostrychia is epiphytic on Statice, Atriplex, and similar plants; consequently the presence of these algae is in part dependent on the character of the phanerogamic vegetation. But the converse is also true. Hill ('09, p. 1.02) and Baker ('12) have shown the importance of the Rhizoclonium covering in connexion with the germination of Salicornia seeds; and the same matted growths doubtless protect seedlings and young plants from excessive insolation.

The Clew Bay salt-marshes agree well as to their flora with the general description given above. The four types of vegetation distinguished were:-

1. Rihizoclonium association.

2. Fucus vesiculosus var. muscoides association.

3. Bostrychia-Catenella vegetation.

4. Vegetation of vertical banks.

The areas specially explored were those on or near Annagh Island, and below the hotel at Mulranuy. Small patches of ground supplying similar vegetation were also examined in Bellacragher Bay and at Leenane.

\section{Rhizoclonium Association.}

lihizoclonium riparium is the dominant species in the felt-like sheets of green algae which are often so conspicuous on the salt-marsh. These sheets are found typically on bare soil (sand, loam, or peat), and at Mulranny are continuous with the Rhizoclonium association, which occurs on the sand from half-tide level and above. On the marsh, Rhizoclonimm is also abundant in shallow pools, and it invades (especially in warm, damp weather of spring), areas colonized by phanerogams. When Phizoclonium alone is present, the growth is light-green; but when, as is often the case, Enteromorpha occurs in addition, the colour is deeper, and does not turn pale to the same extent on drying. Brown and black streaks in the felt indicate the presence of 
Cyanophyceae; in Clew Bay usually Lyngby" confervoides and L. majuscula respectively.

The Rhizoclonium association is more general in some localities than in others, and varies considerably according to the time of the year. Where bare soil is scarce the growth is scanty; where plentiful the felt is, except in spots where strong tidal action obtains, usually abundant. In spring and early summer Rhizoclonium, Percursaria, and Enteromorpha spp. are very luxuriant; later in the season Cyanophyceae develop, and the felt-like growth, as a whole, is not so extensive. The following species compose the association in its wide sense :-

Rhizoclonium riparium, dom.

Enteromorpha torta, $f$.

E. Ralfsii, $f$.

Percursaria percursa, $a b$.

Pylaiella litoralis, $f$.

Lyngbya aestuarii $l . a b$.
Lyngbya majuscula, l.nb.

L. confervoides, l. $a b$.

Cladophora fracta

Chaetomorpha linum in shallow

Capsosiphon aureolus) depressions.

With certain weather-conditions the Rhizoclonium-felt is partially lestroyed. After a high tide, for instance, with a strong S.W. wind, much of the growth at Mulranny is rolled up into rope-like masses; whilst sheets 2 or 3 yards square have been observed deposited on the Glyceria maritimu sward, having been lifted bodily ont of the shallow depression in which they grew.

Fucus vesiculosus var, muscoides Association.

The carpet formed by this remarkable dwarf Fucus occurs above the uppermost Pelvetia (i.e. slightly above the mean high-ticle level), and is thus only Hooded during spring-tides. It is characteristic of peaty shores. Where the shore slopes, the Fucus vegetation forms a distinct narrow band; but where it is flat and salt-marsh conditions obtain, it is much more extensive, and may pervade a large area of the marsh. As a band, it is widely distributed in our area, being frequent in Achill Sound and Bellacragher Bay. On the salt-marsh it is usually found on the best-drained areas.

The association forms a dense mossy turf in which Glyceria maritima is usually abundant, and scattered plants of Statice maritima, Glaux maritima, and Salicomia maritima also occur. Occasionally, however, small patches of pure Fucus nay be noted. The "turf" is composed of fastigiately branched plants which are densely crowded together, with more than half their total length (2-3 inches) buried in the peat. The growth is very erect; but the upright shoots are often found to arise from a more or less creeping stem. 
On firm, well-drained areas, the branches are cylindrical or nearly so, and the whole very short and compact. On wetter areas the shoots are flatter and the growth lax, but it is frequently checked by competition with Rhizoclonium and Euteromorpha. In other cases, the phanerogamic vegeta. tion in clamp soil becomes rank and tall, and then Fucus, when present, tends to assume the form of var. balticus (e.g., at Leenane). Fruiting specimens are always rare.

The plants apparently live for many years, and increase entirely by regetatire methods, proliferations being often abundantly produced from all parts of the shoots. During the spring-tides a certain amount of sand and silt is doubtless depositel, and new shoots continue to arise, whilst the basal portions gradually die away. It is difficult to trace the basal end of the shoot for more than 1 or $1 \frac{1}{2}$ inches below the surface of the soil. The fact that the plants are largely embeided enables them to avoid desiccation even in the hottest weather during the nine or ten days which elapse between each spring-tide. The same fact also meets the difficulty with regard to the presence at so high a level of the mid-littoral species $F$. vesiculusus. In the case of var. volubilis, no one can doubt that the large, vesicled forms (vide Baker, '12) are derived from $F$. vesiculosus; yet under the peculiar conditions of the salt-marsh they occur well above the limit recognized as normal for that species. Thus the high level at which var. muscoides is found is no objection to its being a variety of the same species.

In certain localities, the presence of scattered plants of Statice maritima is a charaeteristic feature. The mossy carpet of Fucus appears to modify the growth of Statice, so that it forms small rosette-like plants instear of the familiar clumps. The leaf-scars may be traced for some distance below the ground-level, and the plants are evidently of considerable age. In May and June the pink blossoms of Statice against the background of Fucus produce a striking effect. The photograph on Plate VI was kindly taken by Mr. G. Massee from a tuft brought home in May, 1911.

As far as has been ascertained, no vegetation of this nature has been previously described; certainly not from an ecological standpoint. It is plentiful at Roundstone, and is doubtless widespread in the west of Ireland. The plant is characteristic of firm peaty soil, and is probably to be found in our islands whererer peat runs down on a flat shore. ${ }^{1}$ On the muddy ground near the mouth of the Bunowen, where there is a covering of Boulder-clay, the var. muscoides vegetation is completely absent.

I Since writing the above I have seen similar associations in the west of Scotland (Loch Linnhe). B.I.A, PROC., VOL. XXXI. 


\section{Bostrychia-Catenella Vegetation.}

The usual growth of Bostryclia scorpioides and Catenella Opuntia as epiphytes on flowering plants occurs in our area, though not in such profusion as in some localities.

The former is very plentiful, and is especially found as a dense growth under the leaf-rosettes of Statice maritima. At Mulramny the older plants seldom lack this Bostrychia-pad. On woody plants, such as Atriplex and Limonium (specially when growing at the sides of streams and channels), it hangs loosely from the lower branches. Catenella is, on the whole, scarce on the marsh, but locally it is abundant.

It is worth noting that both these plants occur near high-water mark on the banks of the Newport River, and in parts of the upper reaches of Clew Bay. They grow here on bare rocks and boulders, showing that brackishwater and long exposure to the air are important factors. A certain amount of shade is usually provided by Pelvetia.

\section{Vegetation of Vertical Banks (peat or loam).}

The vertical peat-banks which occur on the Annagh Island and Mulranny salt-marshes possess a characteristic flora showing well-marked zonation. The same vegetation is even better developed on the peat-banks bordering on the shores of Achill Sound. On the salt-marsh, the banks are seldom more than 3 feet in height, and are much broken up; but at Achill they are higher, and often extend for some distance along the shore. The same type of vegetation, showing the same sequence, is also found on the loam-banks of the Bunowen, but with certain characteristic differences, due to the presence of fresh water (see p. 85). The fresh-water channels of the salt-marsh are also distinct, their banks being muddy and possessing a different flora.

In a general way the vegetation of the peat-banks is disposed in four bands, which invariably occur in this sequence from above downwards:-

1. Phoeococcus adnatus.

2. Rivularia nitida.

3. Vaucheria coronata and Calothrix fasciculata.

4. Rhizoclonium riparium (with scattered plants of F. spiralis, var. nana).

The three lowest bands are usually each about 1 foot deep; but the Phoeococcus band is narrow, and is not infrequently absent. Practically all the tidal banks are cluthed with this vegetation; but at times (especially where moisture is retained?) a growth of $F$. vesiculosus var. muscoides intrudes from the grass above. The essential conditions appear to be regular flooding with salt-water, coupled with complete shelter. 
Vancheria and Calothrix, which form a velvet-like growth of light and dark green respectively, occur often in equal proportions; but at times Vaucheria is dominant. Rhizoclonium forms a dense felt, through which emerge numerous plants of $F$. spiralis var. nana. At Achill Sound (as on the banks of the Bunowen) a band of Rivularia Biasolettiana sometimes occurs above Phoeococcus. An average reading would be as follows :-

\begin{tabular}{|c|c|c|c|c|c|c|c|}
\hline Rivularia Biasolettiana, & . & . & . & & . & $\begin{array}{c}\text { Feet. } \\
0\end{array}$ & $\begin{array}{c}\text { Inches. } \\
1\end{array}$ \\
\hline Phoeococcus adnatus, & . & . & . & & & 0 & $2-6$ \\
\hline Rivularia nitida, . & • & . & . & & & 1 & 0 \\
\hline Vaucheria and Calothrix, & & . & . & & & $1-2$ & 0 \\
\hline Rhizoclonium and F. spix & alis & ar. & ana, & & & $1-2$ & 0 \\
\hline
\end{tabular}

When a vegetation-zone exists below the Rhizoclonium band, it consists of Entrumorphu intestinalis and $F$. spirulis, the latter being larger and stronger than when it occurs at a higher level.

A large number of readings were taken at Mulranny, Annagh Island, and Achill, and, though the amount and luxuriance of the different species differed considerably, the general zonation was invariably the same. Neither was any lifference noticeable on the banks composed of loam, except for the fact that $F$. spircel is was practically absent, the soil being apparently too soft for it to obtain a foot-hold.

The period of submersion can only be ascertained by observations on the syot. At Achill Sound, the neap-tides reach the level of $F$. spiralis, though the salt water soaks up through the peat to Vaucheria and Rivularia. With spring-tides the whole vegetation is flooded, and one may see the top zone of Phoeococcus covered with two feet of water. Slight variations due to local topography are of course frequent.

Comparing the above regetation with that found on the banks of the Bunowen, one notes that $F$. spiralis replaces $F$. ceranoides, and that Enteromor pla minima is absent. The upper zones are the same in both-a fact which is easily understood when the source of moisture is considered. A similar series of plant associations doubtless occurs in other districts where sheltered lanks exist. At Mersea Island (Essex) bands of Cyanophyceae in regular sequence have been noted, but on a much smaller scale than at Achill. The firm peat of the west of Ireland is doubtless more suitable for permanent growth than the soft banks of the Essex coast.

\section{iv. River-Mouths and Fresh-water Streams.}

The method which has been adopted for describing the flora of previous sections cannot easily be followed in dealing with the vegetation oceurring at 
mouths of rivers. Though certain species are found to be constant, it is difficult to obtain generalizations as to the position and sequence of the plantsocieties; and a detailed account is more apt to be merely descriptive of a particular locality. Opportunities for comparison are fewer, not only owing to the small number of streams available, but on account of the different physical conditions afforded by each. In Clew Bay, for instance, there are but three rivers, the floras of which are very different. The Newport river has banks strewn with rocks and stones on which Fucus develops; whilst the banks of the Bunowen are loamy and possess a vegetation of Chlorophyceae and Cyanophyceae. The Westport river is again different. There is also a stream at Belclare which issues as a waterfall amongst rocks in the midst of a luxuriant growth of Fucus ceranoines, and then disperses itself on a muddy shore. In contrast to the above the hill-side streams that descend into Bellacragher Bay and Achill Sound are fairly constant in their flora. For the above reasons it is more satisfactory to treat the vegetation of each stream as such, and not to attempt a general account.

\section{The Newport River.}

This river is tidal for about 3 miles, and has fairly wide banks which support two well-marked plant-communities, namely, an Enteromorpha association and a Fucaceae association of brackish type. The conditions with regard to salinity in such a river are unusually complicated. During heavy rains, the banks may be flooded with fresh water brought down by the stream to a much higher level than usual, and the algae composing the vegetation must be able to endure, not only regular change due to tide, but also prolonged submersion in fresh water.

(1) Enteromorpha Association.-This consists chiefly of E. intestinalis, $E$. molifera, and $E$. clathrata, together with the numerous intermediate forms characteristic of brackish waters. The growth is most irregular and perplexing, and, as the Ulva investigations had shown, any attempt to name all the forms occuring is at present hopeless. Time, therefore, was not wasted on the genus.

(2) Fucrcene Association.-Fucus was more interesting, the most extensive growth of $F$. cercanoides seen in the district occurring here. Starting from the mouth of the river, there is a vegetation composed of Pelvetia, $F$. spiralis, Ascophyllum, and $\boldsymbol{F}$. vesiculosus. On walking towards Newport $F$. ceranoides soon appears. This takes the place of $F$. spiralis, and lower part of the Pelvetia belt. The latter, however, remains a little longer, especially on boulders. $F$. ceranoides meanwhile increases, and gradually usurps the 
position held by Ascophyllum and $F$. vesiculusus, till, at $\frac{1}{4}$ mile below Nemport, the association consists entirely of this species. Ascophyllum is the last to disappear, persisting on boulders, especially in the lower part. At Nemport Bridge, $F$. ceranoides forms a very fine growth, of which some 50 or 60 yards are exposed at low-water; as far as could be seen, it extends right across the river. The association continues above the railway bridge (the exact distance was not noted), where it is covered with perfectly fresh water for many hours at a time. The upper part of the $\boldsymbol{F}$. ceranoides belt (at the Pelretia lerel) consists of very short plants, in some cases barely an inch high. Amongst it exists a certain amount of Catenella aud Bostrychia, especially on slabs of rock. At a lower level the growth is large and vigorous, and shows as usual great blistering of the thallus.

\section{Bunowen.}

Rising in the mountains near Croaghpatrick, and flowing through the town of Louisburgh, the Bunowen cuts a sinuous course through the boulderclay on the plain, and immerges on the sandy shore west of Old Head. The banks for the last mile are loamy and steep, until about $\frac{1}{4}$ mile from the shore, where they tend to become flatter as the river widens out. In wet weather the volnme of water is largely increased; the deep brown stream being perfectly fresh when the tide is on the ebb. Many algae therefore, which are normally left dry and first moistened by the returning tide, are not infrequently immersed for hours in fresh water.

Vertical Bunks.-Begiuning about $\frac{1}{2}$ mile from the shore, we find at lowwater banks 3-5 feet high. Where current is felt, there is constant erosion, and algae are practically absent: but in bays and bends a short vegetation exists, showing definite zonation. The sequence of the bands is usually as follows, beginning at, or slightly above, the average high-water level :-

Phoeococcus adnatus, . . . . . . 2-3 ins. high.

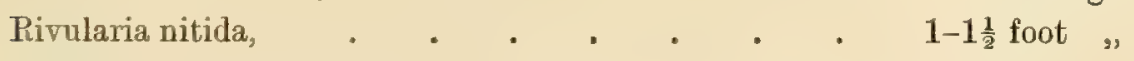

Rhizoclonium riparium and Enteromorpha intestinalis var. 1 " "

Do. with Pylaiella litoralis (F. ceranoides scattered), 1 "

This vegetation extends more or less interruptedly for some distance till a bend and widening of the stream is reached. Several creeks and backwaters then appear, as well as flat, muddy slopes; and the extra shelter is favouratle for Vaucheria, which now becomes prominent. The average 
sequence and depth of the bands on loamy or peaty banks ahout 4 feet high is as under :-

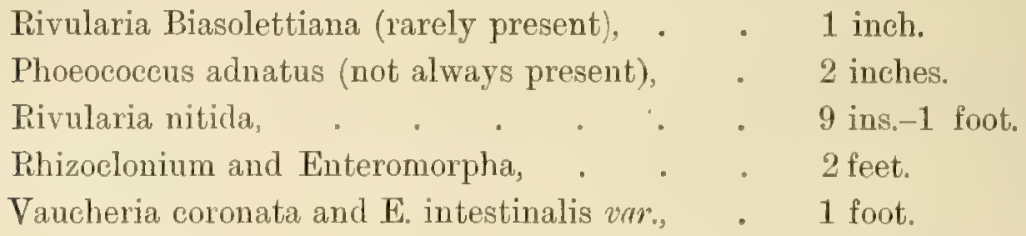

In narrow creaks (which possess little light), Vaucherin coronato clothes the entire surface of the banks, growing very luxuriantly up to extreme highwater level. It forms here a loose furry growth (due to copious branching) instead of the short velvet pile found in open places. Where the banks are flat the growth spreads out horizontally, and the elear zonation is lost. Phoeococeus and Rivularic nitida usually disappear (cf. Bellacragher Bay, p. 89), Rhizochminn, P'ercursaria, and Enteromorpha taking their place, and running in amongst Statice maritima, Glaux mavitima, and Glyceria maritima, so that the whole forms a miniature salt-marsh.

With regard to seasonal development and other details, $R$. nitida, Rhizoclonium, Enteromorpha, Vaucheria coronata are found at all seasons. $R$. Biasolettiana is perhaps mostly a winter and spring species, it being noted in quantity in May only. Phoeococcus forms, on the loamy banks of the Bunowen, a narrow band (cf. Achill, p. 83), and is in places entirely absent. It reaches its maximum development in late summer and autumn, and occurs above the average high-water mark. $\quad R$. nitide is likewise most conspicuous in autumn; in favoured spots the greenish-black band, a foot deep, stretches for many yards; in others it is intermittent, due possibly to the crumbling away of the soil. The Rhizoclonium-Enteromorpha association is practically minterrupted, and is more luxuriant in spring, forming a bright apple-green belt; in summer it becomes bleached, and the linteromorpha constituents are dominant. Monostroma sp. (= M. crepidinum? see p. 107), noted in spring, summer, and autumn, is scattered irregularly throughout this growth; but it is never copious, and is apt to be overlooked. The lower part of the association, which consists of narrow varieties of Enteromorpha intestinalis, merges into the Vaucheria coronata zone. The last-named often stretches a long distance as a pure growth, forming a dark-green, very short, velvet pile. It fruits abundantly, no difficulty being found during any visit in obtaining the characteristic oogonia. If stones exist, $F$. ceranoides may occur near lowwater level; but its growth is poor.

Flat Sloping Banks. - Close to the mouth, the vertical banks give place first to firm mud and then to stony banks, with more or less sand. The 
former, as already indicated, is clothed with $V$. coronate, Rhizoclonium, and Enteromorpha; but many other algae occur, all the species mentioned for the salt-marsh Rhizoclonium association (p. 79) being noted. Beautiful dark patches of Capsosiphon were found in May on stones at half-tide level. $V$. coronata disappears as one nears the sea; but another species with filaments 2-3 inches long, only found sterile, becomes frequent in pools. A fine Microcoleus association (see p. 63) is also present in the sand and sandy mud found between the loamy ground and the stone-covered banks.

With the appearance of stones and boulders the Fucaceae vegetation sets in. At first it consists of pure $F$. ceranoides, but $F$. vesiculosus soon follows, appearing first on the uppermost boulders (where it would obviously receive the least amount of fresh water), and gradually increasing till at the embonchure the two species occur in equal proportions. A second plantassociation is represented on the stones, namely-Enteromorpha intestinalis. This exists as a pure, luxuriant growth in the bed of the stream. In a modified form, it ascends the banks under the Fucus-covering, and in spots forms a green band above it.

F. ceranoides accompanies the river on to the flat sandy beach, and is found on the rocks to the east of the main stream, where it is doubtless under the influence of the fresh water. The association of Porphyra, which occurs below (p. 58), must also receive a certain amount of brackish water.

\section{Bellacragher Bay Streams.}

The streams which descend from the high hills and peat bogs of Curraun Achill seldom if ever dry up, though the amount of water brought down varies greatly. A well-marlied vegetation is present at the outlets, which is quite distinct from that of ordinary streams, and which is probably characteristic of small mountain torrents. It consists of $F$. ceranoides, and a species of Monostroma (No. 91, see p. 107), and does not appear to have been previously described. As a rule there is a large deltoid mass of $F$. ceranoides, with a smaller patch of Monostroma in the upper part; but the physical nature of the shore modifies the horizontal distribution of the algae, so the deltoid form is often more or less lost.

$F$. ceranoides shows first on the stones in the stream near the ordinary high-water line; and on descending the shore it spreads out laterally over the flanks, and continues to low-water mark. Though a large portion remains immersed all day in fresh-water, it is completely covered by each tide. The plants fruit abundantly, but do not attain to so large a size as those found on river-banks (e.g. Bunowen and Newport). 
The Monostroma vegetation is at its best in spring (April and May). It then occurs in deltoid patches, reaching from above $F$. cercuoides to about half-tide level. It covers the rocks and stones in the stream with a dense covering; and also spreads out on either side, growing chiefly on the Fucus. The plants in the streams remain submerged; but those outside are exposed at low-water, and in fine weather dry up rapidly, appearing as a brittle skin, which crackles in the hand. As summer advances, the flank-growth disappears; but in the streams themselves Monostroma was found in plenty during each visit.

\section{v. Vegetation of Brackish Bays.}

The vegetation of inlets surrounded by mountains from which streams descend possesses several distinctive features, and must be recognized as affording a definite vegetation-type. Certain species of diatoms are abundant, also Cyanophyceae; whilst the complete absence of several of the larger algae, and the prevalence of others, are also noticeable.

Other factors, besides the addition of fresh water, have, however, to be considered. Being more or less land-locked, the tide is slight, and the conditions exceedingly tranquil : consequently the aeration of the water is probably very poor. Mineral salts moreover are brought down by the streams, and in our area peaty acids and other compounds from the peat-bogs are doubtless plentiful, the streams being deep brown in times of much rain.

Bellacragher Bay was selected as a spot for systematic investigation. It is land-locked, and, except for a few months in sunmer, receives a large amount of fresh water. Samples of water taken in August showed almost normal salinity, but this was after the dry summer of 1911. This inlet is, therefore, not an extreme case; but the features shown may be useful for this very reason. Bays of much feeebler salinity doubtless occur in Ireland, as they do abundantly in the west of Scotland.

The following associations are represented in Bellacragher Bay :-

Hildenbrandtia-Vervecaria.-Very well marked on stones and pebbles from half-tide downwards, ascending higher in damp places.

Fucaceae.-All five species present. Fronds of $F$. serratus narrow. $F$. ceranoides forming delta-like patches at the bottoms of streams, but not general in any part of the bay.

Lichina.-Very feebly developed. L. confinis most frequent.

Laurencia-Gigartina.-Poor. Isolated patches in sub-littoral region common.

Laminaria.-Sub-association of $L$. saccharina on big stones and blocks of rock frequent. Plants usually long, but not wide, 10 to $12 \mathrm{ft}$. by $1 \mathrm{ft}$. 
Encrusting ATguc-Lithothannium polymorphum belt well developed, usually with Corallina officinalis.

Pebble-attached association.-Extensive and well developed, but poor in species. Examined by wading at extreme low-water,

Zosterc.-Local.

Special features.-Two societies not referred to elsewhere are very prominent in the littoral region. (1) Rivularia nitida, the species of vertical peat-banks ( $p .82)$, occurs as a broad horizontal band. It is noticeable throughout summer, but in October forms a black band along the whole shore. (2) Cladophora rupestris, as narrow strips or effused patches, is also very abundant, indicating the presence of fresh water. It is remarkable that Enteromorpha, which usually serves this purpose, is, except as a short growth near high-water line, almost absent. Associations of Porphyra and Rhodochorton, which might have been expected, were completely absent.

A general coating of the diatom Cocconeis Scutellum is especially characteristic of the vegetation of this bay. Species of Cladophora, Ectacarpus, Polysiphonia, etc, are in spring so completely covered as to be utterly unrecognizable. The plants appear quite black owing to a ring of brown substance round the valves of the diatom. The ring is apparently secreted from the peaty water by Cocconeis. Mr.W. West, who kindly identified the diatom, tells me such a copious deposit is unfamiliar to him.

Fresh-water streans.- See p. 87.

With regard to the flora, the lists kept show that a very large number of species accur in the bay, but in small quantity only. Many species were only found once, but, on account of the poorness of the tide, the low-littoral flora is compressed into a very small space. The dominant associations-Fucaceae, Laminaria, Zostera, and pebble-attached-practically cover the ground, and there are no pools. This type of vegetation is probably not peculiar to Bellacragher Bay, as from cursory observations elsewhere (Killary, Roundstone, also in Scotland) it appears to be frequent in brackish bays of like nature. In summer Cyanophyceae are abundant, especially Lyngbya majuscula, Calothrix aeruginea, C. confervicula, and Anabaena torulosa. Stictyosiphon subarticulata, Dictyosiphon foeniculacens, Striaria attenuata, and Chylocladia kaliformis are dominant on pebbles in spring; whilst in summer Cladophore Pudolphicina, Enteromorph clathrata var, and Spermatochnus occur in extraordinary profusion. Of species apparently absent, the following may be noted:-Mesogloia vermiculata, Nitophyllum punctatum, Griffithsia corallina, G. setacea, and Monospora pedicellata. 


\section{III.-THE ALGAL FLORA.}

\section{1. - Systematic List of the Flora. ${ }^{1}$}

The subjoined list includes all species, and the most noteworthy varieties found during the Survey, with the addition, in brackets, of those recorded previously by other observers. Notes on habitat are given when of interest, and local distribution is indicated, except where the species is of general occurrence. Critical notes on the list are given later (pp. 102 et seq.).

The elassification alopted is that of Batters' "Catalogue of British Marine Algae" (1902), except for the group Melobesieae, for which Lemoine's scheme ('10) has been used. The nomenclature also of that catalogue has been followed, except in the case of certain oll names reviverl by Batters. When these names appeared invalid or doubtful, the usual and more familiar nomenclature has been employerl. Critical work naturally has necessitated a few arditional name-changes.

The following signs and abbreviations are used:-

* = new to Ireland.

$r=$ rare.

$\dagger=$ new to British Isles.

$f=$ frequent.

$\mathrm{CI}=$ Clare Island.

$c=$ commor.

$\mathrm{CB}=$ Clew Bay.

$a b=$ abundant .

$\mathrm{AS}=$ Achill Sound.

$l=$ local.

$\mathrm{BB}=$ Bellacragher Bay.

$y=$ young.

\section{CYANOPHYCEAE.}

\section{COCCOGONEAR.}

Chroococeus turgidus Naeg.-CI, CB, $f$. Isolated specimens on various algae. *Aphanocapsa pallida Rabenk.-CI, CB, f.

"Dermocarpa violacea $\mathrm{Crn}$ - $-\mathrm{CI}, \mathrm{CB}, f$. On various filamentous algae.

Pleurocapsa fuliginosa Hauck.-CI $r$. On bare rocks near high-water line.

* ametliystina Rosenv.-CI, CB, $f$. On Rhodochorton floridulum and Corallina. Hyella caespitosa Born. et Flah.-CB $f$.

\section{HORMOGONEAE.}

Spirulina subsalsa Oersted.-CI, CB, $f$. var. oceania Gom.-CI r. On Halichondria panicea.

*Oscillaria margaritifera Kütz.-CI $r$.

* nigro-viridis $T h w$. CI $r$.

I The additions to the Irish list are caleulated from a revised and annotated copy of Mr. J. Adams" "Synopsis." With regard to the Cyanophyceae, several species, which do not figure in the marine section of the Synopsis, have been previously recorded from Ireland, but from fresh-water or brackish localities. These were listed by Mr. Adams in the fresh-water section. 
* Oscillaria Corallinae Gom.-CIf. On Lithothophyllum incrustans.

laetevirens Crn.-CIr. On Gelidium repens. See note.

brevis Kütz.-CI $r$.

* sancta Küitz.-CIr. See note.

limosa $A g .-C I, O B, f$. See note.

*Phormidium fragile Gom-CI $r$. With Ectocarpus on Patella.

tenue Gom.-CI $r$.

t persicinum Gom.-CI $r$. See note.

+ subuliforme Gom.-CI r. See note.

*Lyngbya Meneghiniana Gom.-CI $r$. On Codium tomentosum in pools.

aestuarii Liebm.-CB c, AS $f$.

majuseula Harv.-CB, AS, $f$.

confervoides C.Ag.-CB $f$. See note.

semiplena J. Ag.-CI, CB, AS, $r$.

lutea Gom.-CI $f$. On rocks near high-water line.

Symploca hydnoides Kütz.-CI $r$. On Corallina in shallow pools.

+ dubia Gom.-CI $r$. On brackish rocks.

:Plectonema Nostocorum Born.-CI, CB, AS, $l$. In Rivularia nitida.

tenebrans Born. et Flah.-CI, The Bills, $\gamma$. In shells of Balanus.

Battersii Gom.-Roonah Point r. With Calothrix scopulorum.

norvegicum Gom.-CI $r$.

Microcoleus chthonoplastes Thur.-AS, CB, $a b$. See note.

* tenerrimus Gom, - AS r.

Calothrix confervicola $A g$, - $-a b$.

* consociata Born. et Flah.-CB $r$. On Fiucus vesiculosus var. muscoides. scopulorum $A g$. $-\mathrm{CI} a b, \mathrm{CB} r$.

pulvinata $A g$. $-\mathrm{CB}, \mathrm{AS}, f$.

* parasitica Thur.-Old Head $r$. In Nemalion multifidum.

* aeruginea Thur.-CIr, Old Headr. See note.

fusca Born. et Flah.-MuTranny $r$. See note.

crustacea Thur.-CI $r$. On limpets in high-water pools.

fasciculata $A g .-A S f$. On peat-banks.

+ endophytica $s p . n o v$.-Annagh Island. See note.

Isactis plana Thur.-CB $f, \mathrm{BB} l$. On stones, and on stems of Laminaria digitata.

Rivularia Biasolettiana Menegh. (= R. coaduncta Fosl),-Bunowen River $f$.

atra Roth.- $-a b$.

nitida $\mathrm{Ag}$.-CB, AS, BB, $a b, \mathrm{CI} r$.

bullata Berk.-CI $f$, Mulranny $f$. On exposed rocks at half-tide level.

"Brachytrichia Balani $B$. and $F$.-CI $r$. In cave at Portlea.

[Mastigocoleus testarum Lagerh.] -Roundstone (coll. Johnson, 1893).

* Microchate grisea Thur.-CB r. On shells in 5 fathoms.

Anabaena torulosa Lagerh.-CB, BB, f. On various algae. 


\section{CHLOROPHYCEAE.}

ProTOCOCCINAE.

Chlorochytrium inclusum Kjellm.—c. In Dilsea edulis.

[Halosphaera viridis Schm.].-i. See note.

*Codiolum gregarium $A . B r$.-CI $f$, Old Head $r$. On rocks near high-water line.

*Petrocelidis Kuck,-CI, Old Head $f$. In Petrocelis cruenta and Cmoria pellita.

\section{CONFERVOIDEAE.}

Prasiola stipitata Suhr.-CI, CB, The Bills, $l$. On bird cliffs $a b$, on bare rocks $l$. crispa var. marina Börg. (= Gayella),-CI $l$, Caher I., The Bills.

Protoderma marinum Rke.-CB, AS, BB, f. On pebbles, near low-water mark. Ulvella fucicola Rosenv.-Old Head $r$. On $F$. vesiculosus, probably frequent.

*Monostroma orbiculatum Thur.-CB $f$. See note.

sp. No. 95 (M. crepidinum Farlow ?).-Old Head, Mulranny, l. See note.

sp. No. 91.-AS, BB, $f$. See note.

Grevillei Wittr.-CI, AS, c. Epiphytic near low-water mark.

var. Cornucopiae Batt.-CI, AS, $r$. On Corallina.

*Capsosiphon aureolus Gobi.--Old Head, Mulranny, $l$.

Percursaria percursa Rosenv. $C$.

Enteromorpha clathrata $J . A g .-c$.

paradoxa Kütz,-CB r, Roundstone (coll. McCalla). See note.

* torta Reinb.-CB f.

prolifera $J . A g .-\mathrm{CB} r$. Attached to stones on flat sandy shores.

compressa Grev. - $a b$.

Linza $J . A g .-c$.

intestinalis, Link. - $a b$.

micrococea Kütz.-CI $r$. On rocks near high-water line.

minima Näg.-CI $c$. On rocks near high-water line.

Ulva Lactuca $L .-a b$. See note.

Ulothrix flacea Thur.-CB f. See note.

* consociata Wille.-Roonah f. See note.

$\dagger$ pseudoflacca Wille,-CI, Old Head, Roonah, $f$. See note.

+ subflaccida Wille.-CB, AS, $r$. See note.

"Phoeophila dendroides Batt.-BB $r$. In old Chylocladia kaliformis.

Bulbocoleon piliferum Pringsh.-CI $r$. In old Chordaria Alagelliformis.

Blastophysa rhizopus Rke.-AS $r$. In old Ralfsia sp. on Achill Bridge.

Endoderma viride Lagerh.-CI, CB, $f$. In Nitophyllum and Delesseria spp.

Wittrockii Wille.- $f$. In Pylaiella litoralis.

Flustrae Batt. $r$. In Flustra $s p$.

Tellamia contorta Batt.-CI, Roonah, $f$. In Littorina.

intricata Batt.-Roonah $r$. In Littorina.

Urospora mirabilis Aresch.-CIf. See note. 
Chaetomorpha litorea Cook.-Mulranny. See note.

[tortuosa Kiitz.] -CI r., Roundstone.

linum Kütz.-CB, AS, c. See note.

aerea Kütz.--CI $c$. In high-level rock-pools.

melagonium Kïtz.-CI $r$, Achill Bridge $r$.

[crassa Kütz.]-Achill (coll. Hanna, 1899).

[Rhizoclonium Kochianum Rütz.] -Rouridstone (teste Batters).

implexum Batt. non Kiitz. (= R. tortnosum Kütz.)-CI c.

riparium Harv. $a b$.

$+\quad$ Kerneri $f$. endozoica Wille-CI, Achill Bridge, $r$. See note.

Cladophora prolifera Kütz. See note.

pellucida Kütz, - CI $r$. In deep or shady rock-pools.

Hutchinsize Harv.-CB $f$.

[Macallana Havv.] -Roundstone (coll. McCalla).

rectangularis Harv.--CB $r$. Dredged in 3 fathoms.

Neesiorum Kütz,_CI $\%$ Rock-pools.

rupestris Kütz,-ab.

[var. distorta Harv.]-Roundstone (coll. McCalla).

sericea Kütz, $-a b$.

glaucescens Harv.-CI $r$. In rock-pools.

flexuosa Harv. - See note.

albida Kütz.-CIf. On rocks and in pools.

var, refracta Thur.-CI $f$. On rocks and in pools.

Rudolphiana Harv,-CB, AS, BB, $f$. See note.

fracta Kütz.-CB, AS C.

[cornea Kütz.] -Roundstone (coll. Painter', 1883).

corynarthra var. spinescens Batt.-BB $l$. See note.

areta Kiutz.-CI c. See note.

uncialis Riutz,-CIf. On exposed rocks.

lanosa Kütz,-CBc. Epiphytic.

Gomontia polyrhiza Born. et Flah.-CB, AS, $f$. In various shells.

SipHONEAE.

Ostreobium Quekettii Born. et F'lah.-Roonah r. In shells. Probably frequent.

Bryopsis plumosa $A g .-\mathrm{CI}, \mathrm{AS}, f$.

[lyppnoides Lamour.]-Roundstone (coll. Harvey).

Derbesia marina, Kjellm.-CI $v r$. See note.

Vaucheria Thuretii Woron.-CB, AS, c. See note.

coronata Nordst.--CB, AS, Bunowen River, c. See note.

littorea Bang. et $A g$. $-\mathrm{CB}$ c. See note.

Codium adhaerens $A g$. - CI $f$. In rock-pools, and on steep, damp rocks. amphibium Moore.-CI $v r$, Roundstone. See note. tomentosum Stackh-CI c, CB, $r$. See note sub C. mucronatum. mucronatum var, atlanticum var. nov.-CI $c ; C B, B B, r$. See note. 


\section{FUCOIDEAE.}

Phogospureat.

Phoeococens adnatus West, comb.noi.-CB, AS, c. See note.

Desmarestia viridis Lam.-CI, CB, $f$.

aculeata Lam.-c.

ligulata Lam.-CI $r$.

[Dresnayi Lam.] -Roundstone (teste Johnson, 1899).

Dictyosiphon foeniculaceus Grev.-CB, AS, BB, c.

hippuroides Kütz.-CI, CB, $e$.

Phoeostroma pustulatum Kuck:-CI $r$. See note.

Litosiphon pusillum Harv.-CI $r$; CB, AS, $c$. See note.

Laminariae Harv.-CI $f$. On Alaria.

Phloeospora brachiata Born.-CI $f$. On Rhodymenia palmata.

Stictyosiphon tortilis Rke.-CB, BB, $c$.

subarticulatus Hauck-CB $c$.

+ adriaticus Kütz.-Bartraw $r$. See note.

Striaria attenuata Grev,-CB c, As $r$. In shallow sub-littoral region.

Punctaria plantaginea Grev.-CB $r$.

latifolia Grev.-CI, CB, $f$.

tenuissima Grev.-CB f. On Zostera.

undulata J. Ag.-CB r, BB r. On Zostera.

*Phyllitis zosterifolia Rke.-CI $r$.

Fascia Kütz,-CI, CB, AS, $l$.

Scytosiphon lomentarius $J . A g .-C$.

Asperococcus fistulosus Hook. - c .

bullosus Lamour.-CB, CI, c.

*Streblonema sphaericum Derb \& Sol.-CI $r$. In Nemalion multifidum.

*Ectocarpus clandestinus Sant,-CI l. On Fucus serratus, October, 1910.

luteolus Sauv.-CI $f$.

* microspongium Batt.-CI $r$. On Ralfsia vervucosa.

tomentosoides Farl.-CI $r$. On Himanthalia and Laminaria.

velutinus Kïtz,-CI $f$. On Himanthalia.

* Battersii Born.-CB $r$. On Taonia atomaria.

simplex Crn.-CI $c$. On Codium tomentosum.

* Holmesii Batt.-CI, AS, r. In caves and on dark ledges.

globifer Kütz, - CI $r$. On exposed ledges.

Mitchellae Harv. (= E. virescens Thur.)-CI $r$.

confervoides Le Jol. $-c$.

var, arctus Kjellm.-CB $f$.

siliculosus Kütz, - $c$.

fasciculatus Harv.-CI o. On Laminaria and Himanthalia.

tomentosus Lyngb.-c.

Hincksii Harv.-CI r. On Laminaria diyatata. 
Ectocarpus [Landsburgii Harv.].-Roundstone (coll. Harvey). granulosus $A g .-f$.

[Sorocarpus uvaeformis Pringsh.] -f. Roundstone (teste Johnson, 1899).

Pylaiella litoralis Kjellmo— $a b$.

Isthmoplea sphaerophora Kjellin.-CI $f$. On Plumaria elegans.

Lyriotrichia clavaeformis Hart,-c.

filiformis Harr:--c.

* densa Batt.-C'B r. On Zostera.

$\because \quad$ repens Hauck.-Old Head r. On Endesme.

†Dichosporangium Chordariae Wollny.-CI $r$. See note.

Myriactis pulvinata Kütz.-CI c. On Cystoseira ericoides and C. granulatc. Areschougii Batt.-CI $r$. On Himanthalia. stellata Batt.-CI $f$. On Dictyota in pools.

= Haydeni Batt.-CI $r$. On Scytosiphon in pools.

Elachista fucicola Fries.- $a b$. flaccida Aresch.-CI, Old Head, c. On Cystoseira gramulate and Halidrys. scutulata Droby.-CI c. On Himanthalia.

"Leptonema fasciculatum Rke,-CB r. On Zostera.

Giraudia sphacelarioides Derb. \& Sol.-CB $r$. On Zostera.

Sphacelaria cirrhosa Ag.-c. See note. britannica Saur:-r. See note.

- plumula Zan.-CB, Roundstone.

Cladostephus spongiosus $A g .-c$. verticillatus $A g .-f$.

Halopteris filicina Kütz.-CBr

Stypocaulon scoparium Kütz:-l.

Myrionema strangulans Giev.-c.

Corunnae Saut,--CI $r$.

papillosum Saur - $f$.

aecidioides Sanr:-CI $r$.

saxicola $K$ uch:-CI $r$. See note.

reptans Fosl.—Old Head $r$. See note.

Ulonema rhizophorum Fosl.-CI $c$. See note.

Hecatonema maculans Sauv.-CI $f$. reptans Kylin.-CI, CB, $f$. See note. speciosum comb. nov.-CI $f$. See note.

*Microspongium globosum Reinke,-CI $f$. See note.

*Cbilionema Nathaliae Sauv.-C1 $r$.

* ocellatrm Sane:-CI $r$.

Ascocyclus orbicularis Magn.-CB c. On Zostera.

* foecundus comb. nov.-CI, Old Head, f. See note.

- Saccharinae sp.nov.-CI $r$. See note. 
Ralfsia clavata Farl.-CI, CB, $f$. verrucosa Aresch.-c.

* ?L. fatiscens :Aresch.-CB r. See note.

†Petroderma maculans $K u c k,-\mathrm{CB} r$. See note.

Spermatochnus paradoxus Kütz,-CB, AS, BB, c.

Stilophora rhizodes $J$. Ag.-AS $r$.

Chordaria flagelliformis $A g .-f$.

Mesogloia vermiculata Le Jol.-CI $f$.

* lanosa Crn.-CB $r$. Dredged in 3 fathoms.

Griffithsiana Grev.-CB, AS, $r$. Washed ashore.

tAcrothrix gracilis Kylin.-CB, AS, $r$. See note.

Castagnea virescens Thur.-CI $c$; Old Head $f$.

Zosterae Thur.-CB, BB, f. On Zostera.

Microcoryne ocellata Strömf.-BB $r$. On Dasya arbuscula.

Petrospongium Berkeleyi Näg._CI $f$. On rocks, and on Ralfsia vernucosa.

Leathesia tuberiformis Aresch. - ab. crispa Harv.-CI vr. See note.

Sporochnus pedunculatus $A g$. -CI, AS, $r$. Washed ashore.

Chorda filum Stackh.-CB, AS, c. tomentosa Lyngb.-CI $r$. In narrow channels.

Laminaria saccharina Lamour.-c. var. latissima (Turn.) Batt.-CB c. var. Phyllitis Le Jol.-CI c.

digitata Lamour.-c. var. stenophila Harv,-CI $c$. var. vallida Fosl.-CB $f$.

Uloustoni Edm.-CI $c$.

Saccorhiza polyschides Batt. (= S. bulbosa De la Pyl.)-CI $f$.

Alaria esculenta Grev.-CI $c$.

Cutleria multifida Grev.-CB f. Dredged 3-5 fathoms.

(forma Aglaozonia reptans Crn.-CB ab. Dredged 3-5 fathoms.)

\section{Fucineae.}

Fucus ceranoides $L$. CB, AS, BB, $c$. See note. spiralis L. -ab. See note.

var. platycarpus Batt.-CB, AS, ab.

var, nanus Stackh.-CB c. See note.

vesiculosus $L_{0}-a b$. See note.

var. evesiculosus Auct.-CI $a b$.

var. laterifructus Grev.-AS $c$.

var. vaảorum Aresch.-CB $\mathrm{c}$.

var. balticus $J . A g .-\mathrm{CB}, \mathrm{As}, c$.

$\dagger$ var. muscoides var. nov. $-\mathrm{CB}, \mathrm{AS}, \mathrm{c}$, 
Fucus serratus L.- ab.

var. angustifrons Stackh.-CI $f$.

Ascophyllum nodosum Le Jol.--CI $r ; \mathrm{CB}, \mathrm{AS}, a b$.

var. Mackaii (Tumer) comb. nov.-Roundstone Bay $f$. See note.

Pelvetia canaliculata Decne et Thur., -ab.

Bifurearia tuberculata Stackh.-Dog's Bay, Roundstone. Rock-pools.

Himanthalia lorea Lyngb.-CI $a b$.

Halidrys siliquosa Lyngb, - $\mathrm{CB}, \mathrm{BB}, c$.

Cystoseira ericoides $A g$. - CI $c$.

granulata $A g .-C B C$. In pools, and in shallow water.

[discors $A g$.$] -Roundstone (teste Johnson, 1899).$

fibrosa Ag.-CI $r$. In rock-pools.

Tilopterideae.

[Tilopteris Mertensii Kütz.] -Roundstone (coll. McCalla).

DicTYOTACEAE.

Dicytota dichotoma $\operatorname{Lam} x$, - $a b$.

var. implexa J.Ag.-CI c.

Taonia atomaria $J . A g .-C B r$. See note.

Dictyopteris membranacea $B a t t_{0}-\mathrm{CB} r$. See note.

\section{FLORIDEAE.}

PorphyreaE.

Conchocelis rosea Batt.-CB $f$. In shells.

Goniotrichum elegans Le Jol.-Off Annagh Island $r$. On Champia parvula.

Erythrotrichia carnea Le Jol.- $f$.

Bertholdii Batt.-Achill f. See note.

* investiens Born.-See note.

Boryana Berth.-CI $r$ On Lanrencia pimatifia.

* Welwitschii Batt.-CI $r$. See note.

Bangia fuscopurpurea $L y n g b .-c$.

*Porphyra coccinea $J$. Ay.-CI $r$. See note.

leucosticta Thur.-CI $f$. On Fucus spp.

umbilicalis Kütz. - $a b$. ' See note.

v'av. laciniata .T. Ag. $-c$.

var. linearis Thur.-c.

Nemalioninae.

*Colaconema Bonnemaisoniae Batt.-AS $r$. In Bonnemaisonia asparagoides. Chantransia virgatula Thur.--See notes.

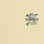

$\because$

$+$ var. luxurians Rosenv,-CI $c, \mathrm{CB} r$. var. tetrica Rosenv.-CI, CB, $r$. var. secundata Rosenv. -ab.

Thuretii Kylin.-CB, AS, c. See note. 
Chantransia endozoica Darb.-CB $r$. See note.

Alariae Jons.-CI $r$. See note.

[Daviesii Thur.]-Roundstone.

Nemalion elminthoides Batt.-CI $f$. See note. multifidum $J \cdot A g$. - CI $c$.

Helminthora divaricata $J$. Ag.-Old Head $c$, CI $r$.

Scinaia furcellata Bivona.-CB $r$. See note.

Choreocolax Polysiphoniae Reinsch.--Old Head $r$. On Polysiphonia fastigiata.

*Harveyella mirabilis Schm. et Rke.-CI, CB, $f$. On Rhodomela subfusca.

Pterocladia capillacea Born.-CI $r$.

Gelidium crinale $\int$. Ag.-Old Head $r$. In sand-pools.

pusillum Le Jol.-CI, CB, $f$.

pulchellum Kütz.-CI $f$.

latifolium Born,-CI $r$.

* aculeatum Batt.-f. See note.

corneum Lamour.- $f$.

GigartinaE.

Chondrus crispus Stackh.-c.

Gigartina mamillosa $J . A y_{0}-c$.

Phyllophora rubens Grev.-CI $l$; Roonah, Old Head, $c$.

Brodiaei J. Ag.--Mulranny r. See note.

Traillii Holmes and Batt.-Roonah $r$. In caves.

membranifolia $J . A g$.-CI, Roonah, $f$.

Gymnogongrus Griffithsiae Martius.--Old Head $r$. In sand-pools.

norvegicus J. $A g$. - Old Head $r$.

Abnfeltia plicata $F r$,- $f$.

Actinococcus subcutaneus Rosenv.-Mulranny $r$, On Phyllophora Brodiaei. aggregatus Schm.-Old Headr. On Gymnogongrus Griffithsiae.

peltaeformis Schn.,-Old Headr. On G. norvegicus.

Colacolepis incrustans Schm.-Old Headr. On Phyllophora rubens.

Sterrocolax decipiens Schm. r. On Ahnfeltia plicata.

Callophyllis laciniata Kütz.- $f$. Washed ashore.

Callocolax neglectus Schm.-f. On Callophyllus laciniate.

Callymenia reniformis J. Ag.-CI $r$. Washed ashore.

* Larterae Holmes.-CI $r$. Washed ashore. See note.

Cystoclonium purpurascens Kütz. -C.

Catenella Opuntia Good. and Wood.-CI $r, \mathrm{CB}, \mathrm{AS}, c$.

Rhodophyllis bifida Kütz.-CI $f$. Washed ashore.

RHODYMENINAE.

Sphaerococcus coronopifolius Grev.-CI $f$. Washed ashore.

Gracilaria confervoides Grev._CB, AS, $c$. See note.

* var. procerrima Batt.-See note. 
Calliblepharis ciliata Kütz.-CIf. Washed ashore.

jubata $K$ ütz.-CI $f$. Rock-pools.

Rhodymenia Palmetta Grev.-CB f. On stems of Laminaria Cloustoni.

palmata Grev.-c.

var. sarniensis Grev.-CB $r$. On stems of Laminaria digitate.

Cordylecladia erecta $J$. Ag.-CB $f$.

Lomentaria articulata $J . A g_{0}-C_{\text {. }}$ clavellosa Gaill. $-f$.

Champia parvula Harv.-CB $r$.

Chylocladia kaliformis Hook. $-a b$. ovalis Hook, -c.

Plocamium coccineum Lyngb.-ab.

Nitophyllum punctatum Grev.-CB, AS, $c$. Bonnemaisoni Grev.-CB, AS, $r$. Washed ashore.

var. crassinerva Batt.-CI $r$. On Laminaria Cloustoni.

uncinatum $J$. Ag. - CB l. See note.

laceratum Grev.-c.

var. uncinatum Batt. $f$. See note on $N$. uncinatum.

Gonimophyllum Buffhami Batt. $-f$.

Delesseria sinuosa Lamour.-c. On stems of Laminaria Cloustoni.

sanguinea Lamour. $-f$.

alata Lamour.-c.

[augustissima Griff.] -Galway (coll. Reilly, teste Harvey in Phyc. Brit.).

ruscifolia Lamour.-CI $r$, CB, AS, $c$.

hypoglossum Lamour.-c.

Bonnemaisonia asparagoides $A g .-\mathrm{CI}, \mathrm{CB}, r$. Washed ashore.

* hamifera $A g$. - CI, AS, Roonah Pt., $r$. Washed ashore. See note.

Bostrychia scorpioides Mont.-CB, CI, $l$.

Rhodomela subfusea $A g .-f$.

Laurencia obtusa Lamour--CB, AS, c. See note on L. hybrida.

hybrida Lenorm.-c. See note.

pinnatifida Lamour.-ab. See note on L. hybrida.

Chondria tenuissima $\mathrm{Ag},-\mathrm{CB} r$.

dasyphylla $A g,-C B, A S, f$.

Polysiphonia macrocarpa Harv.-CI fo See note.

fibrata Harv.-CI c. Especially on flat, semi-exposed rocks.

urceolata Grev.-c.

elongata Grev.-CI $r$; CB, AS, $a b$.

elongella Harv.-AS $r$.

violacea Grev.-CB, AS, $f$.

fibrillosa Grev.-CB $f$.

furcellata Hare,-CI, Roundstone, $r$. 
Polysiphonia fastigiata Grex,-OI $f ; \mathrm{CB}, \mathrm{AS}, a b$. See note.

atro-rubescens Grev.-CI r, CB $a b$.

nigrescens Grev.CB, AS, $c$.

Brodiaei Grev.-c.

subulifera Harv.-CB, AS, l. See note.

fruticulosa Spreng. - c.

Pterosiphonia parasitica Schm.- $f$. In deep pools and in sub-littoral region. thuyoides Schmitz.-CI $f$, Roonah $a b$.

Brongniartella byssoides Bory.-CB $a b$.

Dasya corymbifera $\mathrm{Cru}$. CB $r$. Dredged in 5 fathoms, and washed ashore. arbuscula $A g$. - CI $f$, Bellacragher Bay $r$. See note.

Heterosiphonia coccinea Falk.-f.

Spondylothamnion multifidum Näg, - CI $r, \mathrm{CB} f$.

Spermothamnion Turneri, Aresch.-CI $f$, Old Head $a b$.

i var, subverticillatum, comb. nov,-CB f. See note.

Ptilothamnion pluma Thur,-CI, CB, $f$. On stipes of Laminaria Cloustoni.

f lucifugum sp. nov.-CI $r$. See note.

Griffithsia corallina $A g .-\mathrm{CB}, \mathrm{AS}, a b$. See note. setacea $A g$.--CI $r$, CB $f$.

Halurus equisetifolius Kütz. $-f$.

*Bornetia secundiflora Thur.-CI very rare. See note.

Monospora pedicellata Sol.-CI $r$, CB $\%$. In rock-pools and in sub-littoral region.

Rhodochorton membranaceum Magn.-CB r.

Rothii_Näg.-CI $f$, Roonah $f$. In shady situations only.

parasiticum Batt. $f$. On stipes of Laminaria Cloustoni.

floridulum Näg. $-a b$.

Callithamnion byssoides Arn.-CB, AS, $r$. See note.

polyspermum $A g$. $-f$.

scopulorum $A g$. - CI $f$. See note.

roseum Harv.-AS, BB, $f$.

[tripinnatum Agardh.] - Roundstone $f$ (coll. MeCalla).

Hookeri Ag.-CI c. On Cladostephus spongiosus.

arbuscula Lyngb.-CI c. On steep exposed rocks. See note.

tetragonum Ag, - CI $r$. On blades of Laminaria digitata.

corymbosum Lyngb, -CB, AS, c. See note.

granulatum $A g$.-CI $r$. See note.

Seirospora Griffithsiana Harv.-AS $r$.

* hormocapa Batt.-AS very rare.

[Compsothamnion thuyoides Schm.] - Roundstone (coll. McCalla).

Plumaria elegans Schm.-c.

Ptilota plumosa $A g .-c$. On stipes of Laminaria Cloustoni. See note.

Antithamnion cruciatum Vag.-CI very rare. On vertical locks near low-water. 
Antithamnion crispum J.Ag.- $f$. See note.

Ceramium teurissimm $J . A g .-\mathrm{CB} f$.

strictum Harv.-f.

var. zostericolum Le Jol._CB, BB, $f$.

diaphanum Roth. - f.

Deslongehampsii Chauv.-CI $r$.

Boergeseníi Petersen.-c. See note.

rubrum $A g .-a b$. See note.

var, pedicellatum $J . A y \cdot-c$.

var. secundatum Petersen.-CI f.

atlanticum Petersen. -CI, The Bills, $r$. See note.

flabelligerum $J$. Ag. - CI $f$.

echionotum $J$. Ag.-CI $r$.

ciliatum Ducluz.-c.

acanthonotum Curm.-CI $c$.

CRYPTONEMINAE.

Gloiosiphonia capillaris Carm.-CI $r$. See note.

Dumontia filiformis Grev.-c.

Dudiesnaya verticillata Le Jol.-CI r, CB f. Washed ashore.

Dilsea edulis Stackih.-CI, Roonah, $c$.

Sehizymenia Dubyi $J$. A g. - CI $r$ See note.

Halarachnion ligulatum Kütz.- $f$. IVashed ashore.

Furcellaria fastigiata Lamour.-c.

Polyides rotundus Grev.-CB .

Petrocelis cruenta $J$. $A g$. - CI c. On smooth rocks near low-water.

* Hennedyi Batt.-CB r. On stipes of Laminaria Cloustoni.

Cruoria pellita Lyngb.-CI, CB, $r$. In caves, and dredged in 5-7 fathoms.

adhaerens $J . A g$.-Dredged in 4 fathoms. See note.

Cruoriella Dubyi Schm.-CB $a b$. See note.

Peyssonnelia sp._-CB r; Roundstone $c$. See note.

Hildenbrandtia prototypus Nardo, - $a b$.

*Porphyrodiseus simulans Batt.-CB $r$. See note.

*Rhododermis polystromatica Batt. - CB r. See note.

Rhodophysema Georgii Batt.-CB, AS, c. On Zostera.

Schmitziella endophloea Born. and Batt.-CI r. In Cladophora pellucida.

Choreonema Thuretii Schmitz.-CIr. See note.

Melobesia farinosa Lam.-CB, AS, c. See note.

zonalis Fosl._CB $f$. See note.

Lithophyllum (Dermatophyllum) pustulatum Fosl.-CI $c$. See note.

var. Corallinae Fosl.-CI c. See note.

var. Laminariae Fosl.-CB $f$. See note.

hapalidioides Fosl.-CI, Roonah, $f$. See note. 
Lithophyllum hapalidoides var. confinis Fosl.-CB $r$. See note. incrustans Phil.-ab. See note.

$\dagger$ var. subdichotomum Heydr.-CB, Roundstone, $r$. See note. lichenoides Ellis.-CI, CB, c. Seo note.

[var. agariciformis] Fosl.-Roundstone $r$. See note. fasciculatum Fosl.-CB $\ell$. See note.

Lithothamnium calcarenm Aresch - CB c. See note.

* norvegicum Kjellm.-CB f. See note. laevigatum Fosl.-CI, CB, r. See note. polymorphum Aresch. $-c$. See note. compactum Kjellm.-CB r. See note. Lenormandi Aresch. -c. See note.

* var, sublaevis Fosl.- $f$. See note. var. squamulosa Fosl. $f$. See note. Sonderi Hauck.-CB $f$ ?. See note.

Epilithon membranaceum Hedyr.-CI, CB, f. See note.

Corallina officinalis $L .-a b$. squamata Ellis.-c. See note. rubens Ellis et Soland.-c.

The above list contains the names of 437 species and 36 varieties. Of these 3 species and 2 varieties are new to science; 18 species are additions to the Hora of the British Isles, and in all 92 species and 11 varieties are new to Ireland. For further details consult Part iv, of the present report. ${ }^{1}$

\section{2.-NOTES ON THE LIST.}

\section{Oscillaria laete-virens Crn.}

The cells of the Clare Island specimens are slightly longer than usual in proportion to their width, the filaments being $4 \mu$ wide, and the cells $6-8 \mu$ long.

Portlea, May, 1911 ; with Getidium repens on the under-side of boulders.

\footnotetext{
I Manxe Fung,-Four species of marine fungi were observed, and may be noted here. (See Report No. 13 of the present series.)

Ostracoblabe implexa Born et Flah.-A shell-boring species. CB rare.

Eqricymatia Balani Winter.-Common on barnacles. CB and CI.

Mycosphaerella Ascophylli Cotton. - Constantly present on receptacles of Ascophyllum.

Leptosphaeria Chondri Rosenvinge.-Very rare, and second record for British Isles. On

Chondrus, washed ashore on Clare Island. (For notes on the above fungi see Cotton, '09.)

Miss J. Stephens drew my attention to an endophytic organism growing in the sponge Terpios fugax, and giving it a deep blue colour. The organism is appareutly a Schizomycete (see Topsent, Arch. Zool. exp. et gén. (3) viii 1900). Terpios fugax is rare on Clare Island, but not uncommon at extreme low-water mark on the islands of Clew Bay.
} 


\section{Oscillaria sancta Kütz.}

A fresh-water species, common in Britain; but with the exception of specimens sent out by Holmes ("Algae Rariores," No. 268) it has not been recorded for our islands from a marine habitat.

Portlea, October, 1910; May, 1911; on various algae at mouth of cave.

\section{0. limosa Ag.}

As in the case of many Cyanophyceae, 0 . limosa, though usually a freshwater species, should certainly be included in a list of marine algae. It was found intermixed with other brackish species on piles at the side of a stream at Mulranny (Aug., 1911).

In addition to the above record, a cyanophyceous growth on the sand, both in Achill Sound and at Mulranny, appears to be referable to this species. At Achill the growth occurred between the Fucus plants in the "farms" in the middle of the Sound; and at Mulranny it was found amongst Phizoclonium and Vaucheria on the upper part of the tidal region. The filaments are straight, non-attenuated, non-capitate, bright blue-green in colour, and measure 10-16 $\mu$ in diameter. In some cases a distinct, somewhat mucilaginous sheath is present, a peculiarity which has been noted previously in $O$. limosa, and which led to a rlistinct species, Lymgbya obscura var. acstivalis, being described by Hilse. The only point in which the specimens differed from the normal fresh-water 0 . limose was in the filaments being at times slightly torulose.

\section{Phormidium persicinum Gom.}

This rery distinct species, which is new to the British flora, was described by Reinke in 1889 , and has since been recorded from various localities in Europe and America. The rose colour, coupled with the exceedingly fine filaments $(1 \cdot 5-2 \mu)$ and long cells $(2-7 \mu)$, mark it sharply off from other marine species. The previous record of this plant as British (Journ. Bot., xxxiv, p. 7) was an error, the plant found being Phormidium Ectocarpi Grom. (Batters, '00, p. 369).

Clare Island, October, 1910, forming a dense rose-coloured coating on Codium tomentosum in a rock-pool.

\section{P. subuliforme Gorn.}

The plant referred to this species was found with Calothrix scopulomm on rocks near high-water line. First described by Grunow from St. Paul (Pacific), it has since been recorded from Nehraska and Iceland (Journ. Bot., xl, p. 245). Though not previously noted as marine, it agrees so well 
with Gomont's description that it is here recorded under his name, though it is possible that further work may show that it is a distinct species. In St. Paul and Iceland it nccurred in warm springs; but it is well known that many algae which usually grow in ordinary temperatures are also found in such positions.

Clare Island, Kinnacorra rocks, near high water, October, 1911.

\section{Lyngbya confervoides C. Ag.}

Well known on the north coast of France, but apparently not hitherto

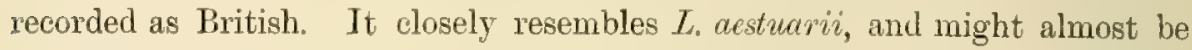
regarded as a form of that species; Gomont, however, keeps them distinct. The Clew Bay specimens are rather slender, usually measuring 10-14 $\mu$ diam. The sheaths, even in old and empty filaments, remain quite hyaline.

Louisburgh and Mulranny, Septemher, 1911, in brackish pools; probably common.

\section{Microcoleus chthonoplastes 'Thur.}

It is surprising that this well-known and cosmopolitan species should not have been previonsly recorded for Ireland, where it forms, as elsewhere, a definite though inconspicuous plant-association (see p. 63). Adams listed it in his "Synopsis" ('08), but excluded it in 1910 (p. 211), as no published record of the plant could be found. It is abundant in Clew Bay, and is doubtless common in other parts of Ireland. I took several samples from the banks of the river Bann in May, 1910.

\section{Calothrix aeruginea Thur.}

Apparently new to Ireland. Recorded by Adams in his "Synopsis," but removed in his second paper ('10, 1). 211). Epiphytic on various algae, especially at Old Head.

\section{C. fusca Born. et F́lah.}

A species usually regarded as being confined to fresh-water; but found in plenty on Rhiaclonium riparium in brackish pools at Mulranny. It was listed by Adams as an Irish fresh-water species.

C. endophytica sp. nov.1 (Plate 10, figs. 1-3).

Plants endophytic in the thallus-cavity of Enteromorpha sp., nearly black in the mass. Filaments simple or rarely slightly branched, very short,

${ }^{1}$ C. Glis intra thullos Enteromorphae entophyticis, brevissimis $70-130 \mu$ altis, $7-10 \mu$ crassis, aeruginosis; vagina tenui, achroa, vel lutescente, sursum gelatinosa, diffluente; trichomatibus $7-8 \mu$ crassis, attenuatis; articulis diametro brevioribus vel subaequilongis; heterocystis 1-2, basilaribus, rare intercalaribus. 
$70-130 \times 7-10 \mu$; blue-green to olive-green; base not thickened. Sheaths thin, colourless, or becoming slightly yellow with age; diffuent above or ausent. Trichomes $7-8 \mu$ thick, attenuated, but not ending in a hair (dried specimens only examined); cells usually shorter than wide. Heterocysts 1-2, basal or rarely intercalary.

In Enteromorpha torte Reinke(?). Salt-marsh, Annagh Island, Oct., 1910.

This species gives to the Enteromorpha filaments in which it grows a leep, almost black, colour, which caused them to stand out conspicuously igainst a background of Rhizoclonium. 'The plant-mass was distinguishable in the field from Oscillaria and Lyngbya, and was collected as a very dark species of Enteromorpha. On examination, however, the tubes were found to contain blue-green filaments, which for the most part were tightly packed along the whole length of the Enteromorpha fronds. A good supply of material was collected, all of which showed the same phenomenon, so that there can be no question of accidental growth.

Its remarkable habitat renders the plant very distinct; and except for C. parasitica, no species of similar habit has been described. In the latter, the filaments are embedded in the thallus of Nemalion; but they occur in fascicles, and project at right angles from the host-plant. The cells of the present species vary considerably in length; and the lateral walls may be straight or markedly torulose. In October, 1910, the plant was plentiful on the salt-marsh; but in May, 1911, it was searched for in vain.

\section{Haplosphaera viridis Schm.}

Mr. G. P. Farran tells me that this species has been noted in the plankton of the Clare Island district during the cooler months of the year.

The following table, drawn up from Gough's list ('04), is of interest in showing the marked seasonal development of the plant:-

Skullmartin (Co. Down), March, April.

South Arklow (Co. Cork), February-April; September, October.

Coningbeg (Co. Wexford), January-May ; September-December.

Fastnet (Co. Kerry), February, March; (July) September-December:

\section{Codiolum gregarium Braun.}

Much diversity of opinion exists as to the limits of the species of Codiolum. All the Clare Island forms occurring conmonly on the rocks in company with Calothrix scopulorum, I have referred to C. gregarium. The plants vary much in size and length of stalk; the hearl in the larger specimens being about $250 \mu$ long by $50-70 \mu$ broad, and passing either 
gradually or abruptly into the stalk; but in any one gathering many intermediate forms are found. It agrees well in form with Braun's specimens (Rabenhorst, "Alg. Eur.," No. 1841), but is somewhat smaller. It also appears to agree with the Berwick gatherings (Holmes, "Algae Rariores," No. 33), which Batters ('89, p. 44) referred to C. gregarium, but which, in 1902, he placed under C. pusillum Foslie. Judging by Börgesen's figure uf the nriginal material ('02, fig. 107), it would appear that Batters' earlier' view was the more correct. The specimens of $C$. pusillum distributed by Wittrock and Nordstedt, and by Hauck and Richter (Exsicc., Nos. 457 and 472 respectively), agree with Börgesen's figure in possessing an extremely long head, and such specimens are easily distinguished from the normal form of C. gregarium.

With regard to the other species, the Clare Island observations tend to show that names have been proposed far too freely; and it is clear that nothing but a special study with careful and systematic collecting throughout the year will bring about a true understanding of the genus.

\section{MONOSTROMA.}

In common with many algae of brackish regions the Monostromas present endless trouble to the systematist; but it would seem that few of these genera would so readily repay careful study in the field. The characters upon which the species are founded-the size, shape, and thickness of the frond, and the size and form of the cells-are known to vary much with external conditions. If the ecology of the plants could be studied, and their growth traced through from the earliest attached stages to the loose floating forms, it is certain that many puzzling intermediates could be placed, and that several of the so-called species would have to disappear.

Of the numerous forms noted in Clew Bay, M. orbiculatum was recognizable; and two others that were sufficiently distinct and frequent to be worthy of record, could not be satisfactorily determined, and are hence referred to by collecting-numbers only.

\section{M. orbiculatum Thur.}

A plant common during April and May in the brackish pools of the saltmarsh near Belclare. It is at first attached to stones, sticks, or leaves and shoots of flowering plants, but finally becomes free. It often grows in dense tufts, and may reach as much as 1 foot to 18 inches across. The fronds are densely plicate, usually orbicular, but sometimes partly sublanceolate; on detachment they become very irregular, but, owing to spring-tides flooding the pools, it is difficult to be certain as to the origin of free-swimming plants. 
No. 91.

This well-marked plant occurs abundantly at the bottom of the hill-side streams which flow into Achill Sound and Bellacragher Bay. It grows attached to stones or other algae such as $F$.ceranoides, and though flooded by every tide, it is for the greater part of the day immersed in fresh water. A certain amount of growth occurs above the average high-water line; and this is bathed in salt water at spring tides; but the plants are small, and the growth rery poor, compared with that of half-tide level. 'The lower limit is at or slightly above low-water mark. Monostroma gives the stony beds of the Bellacragher torrents a deep green colour in spring; but in other streams (e.g. to the north of Achill Bridge) the beds are muddy, and the alga occurs only on the stone fords or where there is good means of attachment. The growth is found in spring, summer, and autumn; in February, also, a certain amount was visible. The maximum is reached in April and May, at which season it extends to the stones and Fuci on the flanks of the streams (see also p. 87).

'I'he plants themselves are of a deep green colour, growing in rosettes or dense tufts, regularly orbicular at first, but becoming more or less lobed or even lanceolate later. They are usually 5-8 cm. across; but lobed specimens reach a length of $15-18 \mathrm{~cm}$. The thallus is thin, that of the adult plant seldom measuring more than $20-25 \mu$ thick, and the cells small, about $10-15 \times 6 \mu$ in section; but in young plants they are often larger. It adheres very well to paper, even in the dry air of the herbarium. The plant has only been found attached, as detached specimens are swept down by the stream and carried away; in a free state, it would probably reach a larger size.

With regard to affinities, the plant agrees in structure with Thuret's $M$. laceratum; but he describes this as floating in ditches with Obione. From $M$. orbiculare, so common near Belclare, it differs in its smaller size and thinner frond; but it is possible that this is due to its peculiar habitat. On the other hand, the plant may be regarded as a small attached form of $\boldsymbol{M}$. latissimum, or as a distinct species peculiar to the situation referred to.

No. 95 (= M. crepidinum Farlow ?).

The second species left unnamed occurs on the banks of the streams on the sandy shore at Mulranny, and at the mouth of the Bunowen at Louisburgh. It is attached to the stems of Ascophyllum and F. vesiculosus (especially on the under branches), but is also found on the stones and rocks covered by these algae, and occasionally in the open. The plants are always 
uncovered during low-ticle, and have not been noted in pools; thus, though swept with a considerable amount of brackish water on the ebb-tide, its habitat differ's considerably from that of the last species. It is not abundant, but has been found, with the exception of the February visit, each time the localities have been searched.

When young, the plants are more or less orbicular, but soon become deeply divided and very irregular. They occur in small elusters and are of mediun size, an average specimen being $10-12 \mathrm{~cm}$. in length; a few larger fronds were found floating in pools; but it was not quite certain if they were detached from this species or from $M$. orbicularis. The thallus is usually about $30 \mu$ thick; and, unless growing in deep shade, is of a very pale colour (cf. No.91).

The agreement with $M$. crepidinum is, in deeply-cut angular specimens, fairly close; but, in others, it is less marked, the fronds being large and irregular. The American specimens in the Kew Herbarium adhere very tightly to paper, which is not the case with any of the Clew Bay material. The lobed fronds appear to separate it from being a marine form of $M$. orbicularis.

Enteromorpha paradoxa var. tenuissima (Kütz.), Batt.

A few specimens of this beautiful species were found washed ashore at Old Head (August, 1911). Though in pour conclition, they are without dumbt referable to the plant named $E$. Hopkivkii by McC'alla. The small chromatophores, and the monosiphonous ultimate ramulae, separate it from the majority of the richly-branched species; and its extreme delicacy distinguishes it from $E$. erecta Hook. The plant has suffered much at the hands of systematists, and its position will probably continue uncertain till the geuus is thoroughly revised. I have followed Batters (without investigating the point) who has united it with Kützing's $E$. tenuissima, which he regards as a variety of that author's $E$. paradowa.

\section{Ulva Lactuca L.}

For recent work on the biology and ecology of Ulva, and especially its growth in polluted waters, see Reports to the Sewage Commission (Letts and Richards '11; Cotton '11 b). An account of the structure of the basal disk has also been published. recently by Miss Delf ('12).

In the pure waters of Clare Island the plant is one of the most abundant species in the more sheltered rock-pools during summer and autumn. It is frequent on rocks also at Portlea and at Old Head; but in none of these localities does it attain a great size. Large specimens nay be dredged in 
Clew Bay, where the water is quiet and muddy; but here it is loeal, and not generally distributed. On the bridge near Murrisk it was noted attached to mussels, as at Belfast and Southampton.

\section{ULOTHRIX.}

The species of Ulothrix were kindly determined by Dr. N. Wille. Two new species are added to the British flora, but one of these may represent the plant named by Batters $U$. implexe.

\section{U. flacea Thur.}

Commou on the Hat shelterer shore of the mainland, but not found on Clare Island, the plant of exposed coasts being now regarded as a distinct species-viz., U. pseudoflace Wille.

On my February visit especially, $U$. Ancen was found in thin, felt-like masses, just below high-water line, on the muddy shores of Clew Bay and Achill Island. The filaments usually measured $40-50 \mu$ diam.; and the cells contained a large ring-like chromatophore with $4-6$ pyrenoids. $U$. flacca is not listed in the "Synopsis" but Mr. Adams tells me that the plant was included as a synonym of Urospores isogona (see Urospora miratilis).

\section{U. consociata Wille.}

Apparently common in the district during winter and spring. It was found on boulders near high-water line at Portlea, and was abundant at Roonah in similar positions during February. Collins ('09, p. 186) designates this species $U$. laetevirens (Kütz.) Collins.

\section{U. pseudoflacea Wille.}

Not previously recorded for the British Isles, though doubtless passed over as $U$. flacce. On Clare Island it is the dominant species of the Bangia. Ulothrix-Lrospora association, and is also frequent us an epiphyte on various algae, especially the stems of Fucus vesiculasus. On Alnahaskilla it formed a dense and tangled coating on Lichine pygmaer.

\section{U. subfiaccida Wille.}

To this species a very slender plant, found on muddy stones near high-tide level, is referred by $\mathbb{W i l l e . ~ T h e ~ f i l a m e n t s ~ a r e ~ o n l y ~} 7-10 \mu$ diam., and possess land-like chromatophores, with one pyrenoid. From the description given by Batters ('89, p. 35) it appears probable that it is the plant referred by him to $U$. implesa Kütz. ; but Professor Wille informs me that it is quite impossible, from the meagre description, to determine the identity of Kützing's species.

Bunoweu liver and Achill sound, February, 1911 
Urospora mirabilis Aresch. $(=U$. isogonu, Batt., '02, p. 14. $)$

This is the common species on Clare Island, only a few filaments doubtfully referable to $U$. Wormskinldii being found in addition. The combination proposed by Batters is questionable. No type of Conferva isogonc Eng. Bot., can be found; and even if it could, it is improbable that its specific identity could be recognized. The present plant was confused, in the older Irish recorils, with Ulothrix flacea.

\section{Chaetomorpha litorea Harv.}

Some small pieces of a Chaetomorpha collected at Mulranny appear to belong to this species. The cells are $90-110 \mu$ diam., and 1-1 $\frac{1}{2}$ times as long, and rather thick-walled. Carmichael's Appin gathering is not to be found at Kew, and consequently Wyatt Exsicc., No. 220, must be regarded as the type (see "Phyc. Brit.," Pl. 333). It is doubtful if the species is not merely a slender form of $C$. linum.

\section{c. linum Kütz.}

Adams records $C$. linum in ('08), but excludes it in ('10). In the second paper it was regarded as a synonym of $C$. crassa; but as it is most unlikely that all the Irish records of this common plant could be referable to that species, I have not considered the Clew Bay gatherings as an addition to the Irish flora.

Rhizoclonium Kerneri Stockm. f. endozoica Wille.

This addition to the flora of the British Isles appears to be not uncommon in the west of Ireland, being found on several occasions during the Survey. It is probably general on our shores, but its curious habitat-within the tissues of the sponge Halichondria panicea-doubtless accounts for its being overlooked.

The first specimens were collected under the bridge at Achill Sound, where patches of sponge of a deep green colour were noted. The latter were found to contain algal filaments which agreed with Wille's description of R. Komrif. ondosoicu that had just been published ('10, p. 291). Specimens were forwarded to Dr. Wille, who confirmed the point, and added, "Es ist doch sehr zweifelhatt ob die Alge zu $R$. Kerneri gehört, aber ich habe keine sichere Vermehrungsorgane gefunden, und möchte deshalb vorläufig nicht eine neue Gattung aufstellen." The alga was found later in sheets of Halichondria in the caves near the lighthouse on Clare Island, and was noted on both subsequent visits to Achill sound, but in each case the specimens were storile, so that no fresh light on the affinities of the alga could be gained. A curious bacterium-like plant living in the sponge T'erpios fugax is recorded on p. 102 (foot-note). 


\section{Cladophora prolifera Kütz.}

One of the interesting additions to the Irish flora, and found on The Bills rocks only. It is not uncommon on various coasts of southern Europe, and a single record exists for the British Isles, the plant having been washed ashore in profusion at Weymouth in November, 1884 and 1885 (see Holmes, "Alg. Brit. Rar,." No. 32). The Irish specimens were found in rock-pools on the shady side of the islets (July, 1910).

\section{c. flexuosa Harv.}

The plant referred to this species was collected in pools under the shade of boulders in Clare Island in July, 1910. It agrees very closely with the specimens in "Algae Danmonienses" (No. 227), on which the species was foundect, though it is open to question whether the plant is not a form of some other species.

\section{Rudolphiana Harv.}

This species, though rare in England and Scotland, is, as noted by Harvey, abundant on the west of Ireland. It is Conferva Kaneana of McCalla " Algae Hibernicae"). The Clew Bay specimens agree well with Harvey's figure and description, and are undoubtedly the same as his plants; but whether they are identical with C'. Rudolphiana, as understood on the Continent and in America, is not certain. (See "Phyc. Brit." Pl. lxxxvi.)

\section{C. corynarthra Kütz, var. spinescens Batt. ('00, p. 370).}

A curious plant, which appears to agree with variety spinescens of this little-known species, was found amongst stones and damp soil near highwater mark at the Mulranny end of Bellacragher Bay. Batters' specimens were collected at Roundstone, and occurred amongst the roots of Zostera. The Mulranny habitat is a remarkable one, the more so as the plant appeared to be confined to the stone-area referred to.

\section{C. $\operatorname{arcta}$ Kütz.}

The name $C$. areta is used here in its wide sense, and includes several other so-called species. Kjellmann's work, though useful, left things in a most confused state. A point which has been largely overlooked is that the original $C$. arcta in its best-known and typical forms has hooked branches, though these are not so numerous as in some of the recently proposed species. Many of Miss Hutchins' Bantry Bay specimens (on which the species was founded by Dillwyn) exist at Kew ; and the plant is common in England and Ireland. Hooked branches are always present. In certain forms (especially those in the north of Britain) the growth is less dense and the recurved 
branches are more numerous. These are inseparable from Arosiphonia albescens Kjellm., and $A$. incurve Kjellm., which Börgesen found so abundantly in the Faeröes. C. Traillii Batters is also hardly distinct from C. arcta. All these forms appear to exist on Clare Island; but they pass imperceptibly into one another. The species vary greatly with age, and with habitat, so that for a-satisfactory revision it is essential that much time be spent in field work.

\section{Derbesia marina Kjellm.}

'Two patches of this plant were found-(1) in a cave near Portlea, and (2) on the dark under-side of a slab, at Kinnacorra, attacherl to Holichondriu panicea. In the latter case the alga formed tufts about $1 \mathrm{~cm}$. high of a pale green colour. At the base there is a mass of creeping filaments, and from these spring upright shoots with numerous lateral l,ranches coming off at an acute angle. The latter are much more slender than in the Finmark and Faeröese plants, being only $20-30 \mu$ diam., but they agree in possessing the short cells at the base.

The cave-specimens (which grew in or at the margins of shallow pools) were much less regular in growth, the branches springing from the main filaments at various angles, but they agreed in size and in presence of the short cells. The matted growth at the base is more copious and the upright filaments are shorter than in the plants from the open. Sporangia were found on the cave-specimens only. These were few in number and hardly mature; the largest measured $120-65 \mu$, which is smaller than those recorded previously.

Kjellmann described D. marina (Lyngl.) in full ; and Börgesen in dealing with its distribution records the plant from Lerwick ('02, p. 520, '03, p. 30.3). Up to the present this has been the only certain record for the British Isles. It appears probable from the Portlea specimens that Crouan's $D$. repens may be a form of the present species.

\section{Vaucheria Thuretii Woron.}

This species occurs half-buried in the mud on the lowest part of the shore; and it covers wide areas of the mud-flats in Clew Bay and Achill Sound (north end). It is distinguished by numerous small sessile antheridia found in the neighbourhood of each oogonium and on the same filament. At times the growth is so covered with mud as to be hardly visible, but even in this state it provides, on washing, excellent fruiting material. Found in fruit, May, July, September, at Annagh Island, Mulranny, and Achill sinund. (See p. 64.) 
Vaucheria coronata Nordst.

Easily recognized when in fruit by the fecundation-tubes which crown the oogonia. It occurs on the upper parts of muddy shores in which it forms beautiful velvet-like sheets of a deep green colour. It is common at Louishurgh (Bunowen River), Ammagh Island, and Mulranny, and was found in spring, summer, and autumn.

\section{V. litorea Agardh.}

Common on the muddy shores of the inner part of Clew Bay. It is monoecious, and fruits freely, Belclare material showing abundance of ripe rogonia in Mar, 1911. The latter are subglobose, and borne on the extremity of straight or recurved branches which in many cases appear to represent the main shoot, indicating that the branching is of a sympodial nature.

\section{Codium amphibium Moore.}

This rare species was found on a ledge at the mouth of a cave on Clare Island (1909 and 1911). In 1909 its identity was doubted, as it appeared possible that the specimens represented a crop of young plants of $C$. tomentosum. But in August, 1911, a much more characteristic growth was found in the same cave, the sheet measuring some $15 \times 9$ inches. A passing shower proved fortunate in showing that the patch occurred in a spot where rain dripped from the roof, which confirmed its claim to be amphibious.

A special search for the plant was made at Roundstone (from whence it was described in 1843) during September, 1911, but without success. The amount of suitable ground in the neighbourhood is large, and though not discovered in a one-hour search, it is quite possible that it still exists.

In the Clare Island specimens, the fronds are $5-8 \mathrm{~mm}$. high, and $1.5-2 \mathrm{~mm}$. thick; the full-grown utricles are clavate aud thin at the apex; they measure, on the average, $500 \times 150 \mu$. The creeping filaments forming the effused stratun at the base are freely lrancherl, somewhat irregular, and contain much r.hlorophyll; they vary from $30-50 \mu$ in thickness. Though a large number of fronds were examined, no fertile utricles were found. Outside Ireland, C. comphibium has been recorded from Cornwall and the Isle of Man.

\section{C. tomentosum Stackh.}

As rreat difficulties exist in many countries with regard to the limitations of $C$. tomentosum, a full description is here inserted. The species varies considerably, and has been recorded from all parts of the world; but as it was originally rlescriber from an English specimen, the British plants may be regarded as typical.

R.I.A. PROC., VOL, XXXI. 


\section{Proceedings of the Royal Irish Academy.}

Description.-Plants rather slender, much branched, 9-15 inches high as

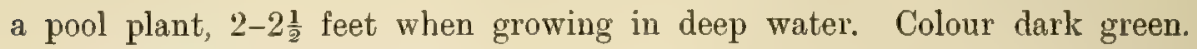
Fronds slender, 3-4 mm. thick, cyclindrical, often slightly flattened at the axils, dichotomous; surface often very tomentose, becoming smooth with age. Utricles cylindrical, small, $500-650 \mu$ long, by $120-170$ (rarely to $220 \mu$ ) wide, apex usually distinctly thickened, blunt; smaller utricles sometimes pointed, but never mucronate. Gametangia ( ( ) small, $200-250 \times 40-70 \mu$; garnetes $20-22 \times 10-12 \mu$.

Habitat.-On rocks near low-watermark usually semi-exposed, or in deep or shady rock-pools; saxicolous or epiphytic: also in the sub-littoral region, often on stipes of Laminaria Cloustoni.

Season.-All the year round; many plants reaching maximum size in winter.

In comparison with many localities on the south and east of England, C. tomentosum is common in the west of Ireland. Very large plants were noted in February, both in pools and from deep water. One specimen on Laminaria Cloustoni measured a yard in length. In most cases the fronds are cylindrical, but in some there is a marked flattening, especially in specimens washed ashore from the sub-littoral region.

The chief points of distinction between the present species and C. mucronatum are (1) the slender branches (3-4 mm. thick), and (2) the small utricles (500-650 $\mu$ long) (cf. figures 1-2 and 3-5, Plate 8). Further, C. tomentosum does not assume a light green colour when growing in sunlight, and it apparently reaches its maximum size during winter, at which season C. mucronatum appears to be almost absent. The utricles moreover are often thickened, but never mucronate. Both species are more or less tomentose, but $C$. tomentosum more of ten so than $C$. mucronatum.

\section{C. mucronatum var. atlanticum var. nov.2 (Plates VII and VIII, figs. 3-5).}

Plants robust, slightly branched, usually $6-9$ inches high, rarely forming large tufts 12-18 inches high, and much branched from below. Colour deep green, bright green when growing in sunlight (due to the presence of bubbles between utricles). Fronds robust, $5-7 \mathrm{~mm}$. thick, entirely cylindrical (not flattened below axils), dichotomous or dichotomously fastigiate, surface smooth or slightly tomentose when young. Utricles very large, cylindrical or slightly clavate, $800-1000 \mu$ long by $250-300 \mu$ wide, apex thin-walled, surmounted in the younger parts of the frond by a small, sharp or blunt mucro, in the older parts mucronate utricles often absent. Gametangia ( $q$ ) large, 300-400 $\times$ $80-120 \mu$.

\footnotetext{
${ }^{1}$ Var. atlanticum. Utriculi parte frondis adultiore laeves vel mucrono brevissime acuto aut obtıgn instructi, parte juniore mucronati.
} 
Habitat.-Sunny rock-pools, common; rocks near low-water or shallow sub-littoral region, rare.

Serson.-Spring to autumn. (Absent in winter?)

Distribution.-Lkeland, Co. Antrim (Giant's Causeway), Co. Donegal

(Bundoran), Co. Mayo (Achill, Clare Island, Roonah Point, Old Head, Bellacragher Bay), Co. Galway (Dog's Bay), Co. Clare (Kilkee), Co. Cork (Bantry Bay, one spee. in Herb. Univ. Cambridge).

Scotrand, Ayrshire (Ballantrae, Herb. Ball, Dublin), Bute (Cumbrae, Herb. Batters), Orkney (Herb. Harvey, Holmes), Iona (Herb. Greville). ISLE OF MAN (Port Erin, frequent in pools).

Exsicc.—C. elongatum, Ag., Holmes, "Algae Rariores," no. 282.

Distinguished from $C$. tomentosum by its more robust fronds, and the very much larger utricles which are often mucronate. The degree of mucronation is rariable in different specimens, and also in different parts of the same specimen. In some individuals it is marked throughont the entire plant, in others in the younger parts only, whilst in a few cases it is absent except in the tips of the branches and in proliferations. In the latter mucronation is often very marked indeed.

The correct determination of this plant gives an additional species of Codium to the continent of Europe. Entirely absent from England, and also, as far as can be ascertained, from Frauce and the Mediterranean, yet abundant on parts of the west of Ireland and known to occur in the Isle of Man and Scotland, it is to be regarded as one of the most interesting of the Clare Island discoveries. Its distinct feld-characters, and the fact that it is no recent introduction, makes its previous non-recoguition the more remarkable.

Before discussing the question of the Irish plant, it may be well to refer to $C$. mucronatum as generally understood. J. Agardh founded the species in 1886. He distinguished three varieties (with no definite typical form) as follows:-

\section{var. tasmanicum, Tasmania and Australia. var. Novas Zelandiae, New Zealand. \\ var. californicum, California.}

The characteristic feature of the species was the mucronate utricle; and the varieties were based on the degree and form of mucronation. In addition to the countries mentioned, the plant has since been recorded from South Africa, Japan, and Cape Horn, but not from the North Atlantic. 'There is a plentiful supply in herbaria of both Australian and Californian material. An examinariuu

\footnotetext{
1 The Japanese and South African specimens require verificution.
} 
of the Kew specimens tends to support Agardh's conclusion that all three varieties belong to one species, and shows that in a general way mucrunation is correlated with robust habit and very large utricles (points not noted in the original diagnosis). The Irish plant does not agree exactly with any of Agardh's varieties. It resembles closely var. Novae Zchndiae, but differs in the usually blunter mucro, and also in the occasional partial absence of this structure.

Notes on the mucronation of the four varieties are given below, Agardh's description of the first three being amplified or slightly emended.

var. tasmanicum.-Utricles in youngest parts tapering to a long sharp point; in older parts broad, cylindrical, sharply mucronate. DistributionE. and S.E. Australia and Tasmania.

var. Novae Zelandiae.-Utricles surmounted with a small, sharp mucro, in both young and old parts of the fronds, but usually slightly more marked in the younger. Distribution-New Zealand and E. Australia.

var. californicum.-Utricles surmounted with a long or short mucro, which, though sharp at first, is usually blunt later, and sometimes apparently articulate. Mucro very variable in length, sometimes partially absent. Distribution-Pacific Coast of N. America, (Japan?)

var, atlanticum.-Utricles in younger parts surmounted with a very short, sharp or blunt mucro; in older parts utricles sometimes non-mucronate. Distribution -N. and W. of Ireland, Isle of Man, S.W. Scotland, Orkneys.

The above four varieties form an irregular series with regard to their mucronation. Var. californicum, although in sume respects intermediate between tasmanicum and Norac Zelandice, is apart from both in the bluntuess, articulation, and occasional great length of the mucro.

Identification of the Irish Plant.-It is certainly remarkable that so conspicuous a species should have so long escaped attention. Known from Kilkee, and plentiful in the pools at Dog's Bay, Roundstone, it is almost incredible that such acute observers as Harvey and Mccalla should not have detected it. A single specimen collected in Bantry Bay by Miss Hutchins (Cambridge University Herbarium), and two collected in 1839 from the Ayrshire coast (Dublin National Museum), show that it is no recent introduction.

The plant attracted attention on the first day spent on Clare Island, and on one or two occasions only was there the slightest difficulty in distinguishing it at a glance from $C$.tomentosum. Its light-green colour in summer, and preference for shallow sumny pools, cannot fail to strike the collector, whilst its sturly hahit is also noteworthy. With the exception of the last, these characters are not of course visible in the dried specimen, and 
hence herbarium botanists have been off their guard, and have not detected the microseopic characters which are even more striking and important.

Batters was the first to recognize the species as distinct. In 1897 he received a specimen from Killiee collected by E. George, and this he identified with the Mediterranean $C$. elongatum. He did not apparently record the discovery; but in his "Catalogue" (1902) he lists C. clongatum, and gives Kilkee as the only locality. On my return to London after the first Survey visit, I examined Batters' specimen. In external form it agreed fairly well with small specimens of $C$. clongatum, and possessed large utricles, as does that species. The Clare Island gatherings differed somewhat; but it was estahlished berond question that the two plants were specifically iclentical. As there was no other European Codium to which the species could be referred, the name $C$. clongatum was accepted, though each subsequent visit rendered the ilentitication more questionable. Occasional mucronation was noted; but this was regarded as an irregularity.

During the second season the matter was thoroughly investigated, and herbarium material of all known species of Codium was examined. As a result, the Irish plant was found to be constantly more or less mucronate, and to resemble very closely the Australian plant C. mucronatum J. Ag. As the position of this species in Europe would.be extremely isolated, and since the Irish plant was decidedly less mucronate than the Australian, it was at first thought advisable to describe it as a new species. But on further investigation it was found that, as far as could be ascertained from dried material, it differed in no important particular from Agardh's species, the Australian gatheriugs varying largely auongst themselves as to degree of mucronation. Further, the Irish plaut differed much less trom var. Norae Zclandiue than does that plant from var. tasmanicum, whilst the Californian variety is far and away more distinct. On the other hand, it was umlesirable, in the present state of our knowledge, to definitely link the European plant with var. Novae Zelandiae. I have therefore described it as a new variety, which may be distinguished from the last-1amed by the small size of the mucro, and by its partial absence in some cases.

The drawing on Plate VII shows its robust habit, ${ }^{1}$ and on Plate VIII the form and size of the utricles are depicted. 'Though mucronation may at times be absent, the greater length of the utricles, and the absence of apical thickening, render these structures perfectly distinct from those of C. tomentosum (cf. figs. 1-2 and $3-5$ ).

1 Unless the specimen be carefully dried, the stout character of the branches may be lost, as is the case in many herbarium specimens. On the other hand, it is possible by excessive pressure to give specimens of $C$. tomentosum the appearance of $C$. mucronatum. 
Biology and Ecology.-The bright green colour referred to is an optical effect due to the presence of air-bubbles between the utricles. Two explanations suggest themselves: (1) A physiological disturbance in the tissues due to the heating of the pools, and (2) the retention of oxygen given off during photosynthesis in bright sunlight. Plants growing in the shade are dark in coluur, as were those collected in February. But in April, when there is sufficient sunlight to cause heating and rapid photosynthesis, the bright green appearance is, on the south shore of Clare Island, everywhere in evidence. At the Giant's Causeway, however, where the coast faces north, a few plants collected on May 1 were still dark. It is noteworthy that when C.tomentosum grows in sumny pools, which is very rarely the case, no gas is found between the utricles, and the normal colour is retained.

The habitat of our plant is well marked. It is distinctly an alga of sunny rock-pools, being found at any level, but more commonly at a quarter to threequarter tide. It also occurs occasionally in the shallow sub-littoral region, or on bare rocks near low-water mark, where, though liable to be exposed to the air during the lowest tides, it may attain a large size. In this position it is dark in colour. In a general way the plant is frequent on the south shore of Clare Island; also at Roonah and Dog's Bay. It prefers moderately open rocky ground, but extends into Clew Bay as far as Old Head. Several plants were noted in the quiet, brackish waters of Bellacragher Bay; but they were decidedly unhealthy, the fronds being not only irregular in form, but exhibiting abnormalities in microscopic structure. The utricles were for the most part strongly mucrouate, and showed a tendency to become irregularly thickened at the apex.

C. mucronatum var. atlanticum appears to be an annual. On the February visit young plants only were observed, and large plants are prevalent in summer, though a few sporelings may be found all the year round. C. tomentosum, on the other hand, attains its maximum size in winter.

Distribution. - The remarkable feature with regard to distribution is not so much its link with the Australian forms (our other species, C. tomentosum and C. adhariens, apparently occur in the Southern Hemisphere), but its isolated position in Europe. It is not known from the Mediterranean or from North Africa, and is apparently entirely absent from the remaincler of the North Atlantic. Dr. Marshal Howe, who has collected largely on the American coasts and in the West Indies, writes in reply to an inquiry, that as far as he is aware "no mucronate Codium has ever been found on the Atlantic coast of North or South America, or on any of the outlying islands."

The distribution in the British Isles is given on p. 115. No English or French specimens have been found in any of the herbaria examined; neither 
have friends in England or Wales, to whom I have written, been able to detect it on the shore. Professor Harvey Gibson kindly sent a plentiful supply from the Isle of Man; and stated that the plant is frequent in the pools at Port Erin (Bradda Head), but was not noted elsewhere. Judging from certain statements in his memoir ('00), it was probably established there in 1900 . The herbaria examined were as follows:-Kew, British Maseum (including Herh. Batters), Trinity College, Dublin (including Herb. Harvey), National Museum, Dublin; Birmingham University (Herb. Holmes), and Cambridge Lniversity; Edinburgh University (including Herb. Greville).

Phoeococcus adnatus West, comb. nov.

(Gloeocystis adnata Näg., Batters Cat., p. 9).

Owing to the difficulty in ascertaining the correct group to which it belonged, this alga caused considerable trouble, and was ultimately determined by Professor G. S. West. The plant was imperfectly described by Cooke and Pabenhorst under the name of Gloeocystis adnate Näg., and was listed thus by Batters (l.c.). It is recorded from four localities in England; and was added to the Irish flora during the Lambay Survey. In Clew Bay it is common, forming a definite zone of dull-yellow colour on the vertical peatbanks (p. 82). Professor IVest informs me that the species certainly belongs to the Phoeophyceae, and should be removed from Gloeocystis to Phoeococcus; also that he hopes to publish shortly an account of the genus, and will include observations on the minute structure of the present species.

\section{Phoeostroma pustulatum Kuck.}

The alga here referred to is the plant not uncommon on the tips of Laminaria saccharina var. Phyllitis, and which was identified as $P$. pustulatum by Batters (Journ. Bot., xxxiii, p. 275). It appears to differ slightly from Kuckuck's plant; and further investigation may show that it should be separated as a distinct species.

\section{Li tosiphon pusillus Harv.}

Abundant on Chorda, Zostera, and not uncommon on other algae. Occasionally it is found on rock amongst such species as Rhodochorton floridulum.

\section{Stictyosiphon adriaticus Kütz.}

A few specimens of this species, which is new to British flora, were dredged in Clew Bay (in 3 fathoms) during May, 1911. They were noted as unfamiliar on dredging, and were ultimately referred to Kjellmania soriferre Reinke. Dr. Kuckuck, to whom a fragment was sent, confirmed the 
identification ; but tells me that Reinle's plant is synony mous with Stictyosiphon adriaticus. The branches in the latter alga, though usually regarded an opposite, are frequently alternate. The distribution of $S$. adriuticus is therefore much wider than was formerly thought, the plant being known not only from the Mediterranean, but from Kiel (Reinke), Cherbourg (Kuckuck, 1904, in litt.), and Clew Bay (1911).

\section{Dichosporangium Chordariae Wollny.}

(Hedwigia, xxv, 1886, pp. 127-130, tab. I, figs. 1-5, tab. ii, fig. 3.)

Though not previously detected in the British Isles, this minute endophyte is probably frequent in the old fronds of Chordarin flagelliformis, as it is in Heligoland. The Clare Island specimens were found in October, 1910, in fronds that were also infested with Bulbocoleon. The plant is not related to the original species of Dichosporangium (i.e. D. repens $=$ Myriotrichin repens Kuck.); and there appears to be no reason why it should not be placed in Streblonema.

\section{Sphacelaria britannica Sauv.}

Professor Sanvageau, who kindly looked over the material of Sphacelaria, confirms the determination of this species, which is not uncommon on boulders in caves and in similar shady spots. 'The plant was added to the list of Irish algae by Batters, who found it at Lambay.

\section{S. cirrhosa Ag.}

Exceedingly common in our area, extending from the shallow-littora] zegion, through the littoral, and up to the highest rock-pools. It is usually epiphytic; but on semi-sheltered shores it forms an element in the sandassociation of the Rhodochorton floridulum. In this condition it has often been mistaken in the past for $S$. radicans.

\section{S. plumula Zan.}

New to Ireland. A few specimens of this were dredged in 4 to 5 fathoms in Clew Bay and at Roundstone.

\section{MYRIONEMACEAE.}

The Myrionemaceae, as presented in our algological works, are in great confusion, but it is hoped that the monograph, shortly to be published, will bring about a measure of order. In the present report some of the results are forestalled, alterations in nomenclature being made when necessary, and an explanation given. 


\section{Myrionema saxicolum Kuck.}

Some very beautiful specimens of this rare plant were found on limpetshells on Clare Island in October, 1910. The sporangia and filaments were slightly larger than in the Heligoland material, but Dr. Kuckuck tells me it is undoubtedly the same species.

\section{M. reptans Fosl.}

(= Ectocarpus reptans Crouan; Ascocyclus reptans Reinke; Phycocelis reptans Kjellm.; Chilionema reptans Sauv.; Hecatonema reptens Sauv.; Hecatonema fucicolo, Kylin).

Though no one has thrown more light on the Myrionemaceae than Professor Sauvageau, a few alterations with regard to his "Mémoire" have been found necessary. The present plant proves to be a Myrionema, and not a Chilionema; hence Foslie's name is restored. It is frequent in the south of England on Fucus spp., but is apparently rare in Co. Mayo, having been searched for on many occasions, but found once only.

\section{Ulonema rhizophorum Fosl.}

It is most probable that Ulonema is merely a form of $M$. strangulans nccurring on Dumontia, but some curious stages occasionally found make one hesitate to reduce it till the point has been more thoroughly investigated.

Hecatonema reptans Kylin (= Ectoccrpus reptans Kjellm., non Crouan); Streblonema reptans De Toni).

The full synonymy of this species and $M$. reptans will be given in the Monograph. Suffice it to say here that I have examined Kjellman's type, and there is no doubt that it should be placed in Hecatonema. It is not uncommon in our district on Cladophora scricea and C. mpestris.

H. speciosum Cotton, comb. nov. (= Myrionema speciosum Börg.; Hecetonema diffusum Kylin).

'I'he type-specimens of both these plants have been examined; and it is quite clear that $H$. diffrusum $\mathrm{Kylin}$ is an early stage of Börgesen's $M$. speciosum. Hecatonema is, however, the most suitable genus. The plant is common in the British Isles, especially in spring, and was noted frequently in Clare Island on a variety of plants during both the April trips.

Microspongium globosum Reinke (= Myrionema globosum Fosl.; Hecatonema globosum Batters).

A difficult species to place; but when well grown it is evident that it is most suitably located in the genus Microspongium.

R.I.A. PROC, VOL, XXXI. 
Aseocychus foecundus Cotton, comb. nov. (= Phycocelis foecunda Strömf.; A. sphaerophorus Sauv.; A. islandicus Jons.).

Phyoocelis foecunda has long baffled algologists. The type-specimen shows that it is an Ascocyclus, and identical with the plant so well deseribed by Sauvageau as A. sphaerophorus. The number of ascocysts varies greatly in different specimens; but, as Strömfelt's name suggests, the sporangia are very numerous. Common on Rhodymenia palmata.

A. Sacoharinae sp. nov.' (Plate X, figs. 4-9). A. affinis Cotton, '07, non Sved.

Plants forming dark brown circular spots $1-2 \mathrm{~mm}$. diam., rarely $3-4 \mathrm{~mm}$. Discoid thallus monostromatic or partly diplostromatic, $8-14 \mu$ thick, not parenchymatous in centre; margin rather irregular; radiating filaments regular, 7-8 $\mu$ wide, by $1-2$ times as long; chromatophores $4-6$. Hairs numerous, basal; sheath well developed; adult cells $60-80 \times 7-8 \mu$. Assimilating filaments few or absent, simple, cylindrical, 70-120 $\mu$ long, thinwalled; cells, $7-9 \mu$ wide by 1-2 times as long. Ascocysts usually abundant, appearing very early on conspicuous wide margin of basal thallus, sessile, rarely stalked, thick-walled towards the base, typically clavate, $30-40 \times 9-10 \mu$ (on young plant sometimes globose, $15 \times 20 \times 10-14 \mu$ ). Unilocular sporangia unknown. Plurilocular sporangia very abundant, sessile, subsessile, or stalked, lanceolate or elliptic-oblong, rather small, $30-40 \times 10 \mu$ (on old plants $30-55 \times 10-12 \mu), 1-2$ seriate; locali $4-6 \mu$ high.

Habitat.-On Laminaria saccharina.

Fruiting Season.-Early spring till late autumn.

Distribution.-England (Swanage, Weymouth, Plymouth), Ireland (Clare Island).

This species, hitherto undescribed, is not uncommon on the south coast of England, and was found more than once on Clare Island. It occurs on young plants of $L$. saccharina, usually on the decaying tips of the fronds, where it forms dark-brown spots often intermixed with Myrionema Corunnae. It may, however, also occur on older fronds, in which case it is usually larger and often presents irregularities in microscopic structure.

'The species most closely resembles $A$. foecundus, but it differs in the typically clavate ascocysts, although in young plants there is a tendency for these bodies to be subglobose. The spots formed are not so large, and the

\footnotetext{
1 Maculae minutae, fuscae 1-2 (raro -4) mm. diam. Discus unistratosus vel partim duostratosus, cellulis circa 12-16 $\times 6-8 \mu$, organa verticalia emittens (1) pilos numerosos, cellulis $60 \times 80 \times 7-8 \mu$, (2) fila assimilantia rara, breva, $7-9 \mu$ lata, chromatophoris $4-6$, minutis (3) sporangia plurilocularia numerosissimn, sessilia vel breviter aut interdum longius pedicellata, elliptico-oblongata, 1-2 seriata, plerumque $30-40 \times 10 \mu$.
} 
plant is usually smaller in all its parts, especially in the basal thallus. It is, moreover, apparently to be found throughout the entire year, whereas A. foecundus has a much shorter season.

Ralfsia verrucosa Aresch.

Very common in many parts of our district. In shallow rock-pools on the upper part of the shore it forms large spreading sheets, which may completely cover the bottom. At a lower level it usually occurs on bare rock. Occasionally it was dredged from the shallow sub-littoral region.

\section{Lithoderma faticens Aresch.}

It is disappointing not to be able to record this plant (a species supposed to be widely (listribnted) with certainty for Ireland. Many Lithodermalike plants were dredged in Clew Bay during summer, but these, as was expected, proved sterile. The special February trip provided a large number of specimeus, some of which Dr. Kuckuck informs me can be doubtfully referred to Lithoderma. A few of the specimens obtained proved to be Petroderma nuculiforme, which shows the risk of naming these plants from imperfect material.

\section{Petroderma maculiforme Kuck.}

A few specimens of this species (which is an addition to the British flora) were detected by Dr. Kuckuck amongst material dredged in Clew Bay during February. 'I'he plant resembles Lithoderma very closely in external appearance, but differs in the character of sporangia and other minor points.

\section{Spermatochnus paradoxus Kütz.}

Extremely abuuclant during July and August in the low-littoral of Achill Sound, Bellacragher Bay, and in the inner part of Clew Bay. It is epiphytic on many of the larger algae, and forms large taugled masses a yard or more square: in some of the channels of Achill Sound it is for a time completely dominant. In coutrast to the present species Stilophora rhizodes is comparatively rare.

\section{Mesogloia lanosa Crn.}

Several plants of this rare alga were dredged near the lighthouse in Clew Bay during July, 1909. Its season is probably short, as it was not met with in any subsequent dredgings.

\section{Griffithsiana Grev.}

It was very satisfactory to find during the last days of the field-work the true $\boldsymbol{M}$. Griffithsiania, since the specimens collected as this species in 1910 
proved to be Acrothrix mircubilis. The plants are indistinguishable in the field, but with microscope the greater length of the peripheral filaments of the present plant are at once noticeable. Found floating near Achill Bridge and at Old Head, September, 1911.

\section{Acrothrix mirabilis Kylin ('07, p. 93).}

The specimens on microscopic examination were at first determined as Mesogloia neglecte Batters, with which they agree closely; butDr. Kuckuck inforns me that they are identical with $A$. mirabilis Kylin, authentic material of which he has seen. Kylin's genus is based on a good character, and should be maintained; but if the two plants are synonymous, Batters' specific name should be employed, as he first detected and published the species (Jourı. Bot., 1906, p. '2). A difficulty, however, presents itself, since the type of $M$. neglecta caunot be found in the Batters collection, and hence it is impossible to re-examine the points in which the Clew Bay material differs from the description. The discrejancies are trivial, but until we are certain that all the Mesogloiae of our shores are known, it seems wiser to let $M$. neglecte stand as a separate species, and not to link it with $A$. mirabilis.

The present plant bears a striking resemblance to $M$. Griffithsiun, and was assumed to be such on collecting. It is remarkable also that it was found in practically the same localities. Four plants in all were taken, two at old Head and two at Achill Sound, July, 1910.

\section{Leathesia crispa Harv.}

A few specimens of L. crispa were collected during the first trip to Clare Island, but on no subsequent visit. In Journ. Bot., xlvi, p. 329, I have dealt with the synonymy and distribution of this species.

\section{Fucus ceranoides L.}

Invariably present where fresh-water streams occur on sheltered shores. (See pp. 83-88.)

\section{F. spiralis L.}

For remarks on the various forms assumed by this species see Fucaceae associations (pp. 23 and 51). One variety, however, requires special notice.

Var, nanus Stackh.-In many spots in Achill Sound, the sheltered form of var. nanus is found growing on vertical peat-banks at high-water mark. An unbroken series may at times be traced from the normal form. The plants measure 1-4 inches in length, are slightly (1-3 times) branched, and fruit freely at the proper season. In many of the receptacles examined the oogonia were unripe (May); but they appeared to be perfectly healthy 
and not abortive. Occasionally specimens only 1 inch high were observed in fruit. In channels on the salt-marsh, the same plant occurs; but it is not so easily traceable to the normal $F$. spirclis, and is liable to be confused with $F$. resiculosus var, beltirus. It may be distinguished from that plant by its slightly wider, regularly bifureating fronds, over which the eryptostomata are evenly distributed, and by its scattered habit. The fronds, moreover, are always fertile in summer: and their hermaphrodite conceptacles, with projecting paraphyses, are very marked.

F. lutarius Kütz., which has lately been described with great care by Saurageau (08), agrees with $F$. spirclis in possessing projecting paraphyses -a character which strongly suggests that it may he a reduced salt-marsh furm of that species. In F. luturius the conceptacles do not reach maturity, ancl the cryptostomata are marginal. A difference in form, together with an abundance of proliferating branches, is also noticeable; but this may be caused by its peculiar habitat (mud-banks). Proliferating specimens of $F$. spivalis var. namus were frequently noted at Mulranny.

\section{F. vesiculosus $\mathrm{L}$.}

See notes on Fucucece association (pp. 23 and 51).

Var. evesiculosus, auct.-To var. evesiculosus auct. I refer the short nonresicled form of $F$. vesiculosus which is abundant on Clare Island. The name is not altogether satisfactory; but till the British Fuci have been studied and described in greater detail, it appears the most suitable. The plant is abundant on, and characteristic of, exposerl coasts in west Ireland, and also in south England. It is found likewise in the north of France, and is probably similar to that recorded by Sauvagean, under the above name, from north Spain ('97). A non-resicled form of $F$. resiculosus is described by Kylin for the exposed shores of west Sweden; but this variety, which he identifies as compressus rucemosus Kjellm, is, judging from specimens kindly sent by him, a decidedly longer plant, of a much less sturdy habit.

Var. balticus J. Ag,-To this plant I have referred a dwarf Fucus colerably abundant in Clew Bay, which is intermediate in size between F. vesiculosus var. volubilis (Huds.) and the very dwarf form described below as var. muscoides.

Great confusion exists with regard to the identity and nomenclature of these forms. The paper just published by Miss Baker ('12) clears up the uncertainty as to $F$. volubilis Huds. The many different forms assumed by this plant on the salt-marshes of Essex and Norfolk are described and illustrated; and I au indebted to Miss Baker for notes on the differences 
between the Clew Bay and the East Anglian forms. ${ }^{1}$ The specimens collected by Ray at Chichester and referred to by Hudson in his original description of $\boldsymbol{F}$. volubilis (Fl. Angl., ii., 1778) are unknown; but there can be no doubt that Miss Baker is correct in referring the twisted plant described by her from Mersea Island and Blakeney to the Fucus volubilis of Goodenough and Woodward (1797), and of Turner ("Synopsis," 1802), who cite it from Frambridge Ferry and Wells, respectively-localities in the immediate neighbourhood of those she has investigated. Several Frambridge Ferry specimens exist, moreover, in the British Museum.

The smaller forms of this same plant, $\boldsymbol{F}$. volubilis Hudson, have, on the other hand, often been referrel to $F$. vesiculosis var. balticus. At Mersea Island, the dwarf forms are clearly linked by intermediates with the large twisted forms; but in Clew Bay it is otherwise, large plants being entirely absent. This being the case, I have thought it best to use the name balticus, which has already been employed for the Irish plant (Harvey, Johnson, Batters). At the same time the whole question of $F$. balticus requires investigation, as it is highly probable that more than one plant is included under that name. Svedelius ('01) shows that several dwarf Fuci occur in the Swedish Baltic, all of which he regards as varieties of $F$. resiculusus. Before, therefore, the identity of our British plants can be settled, a careful examination of Agardh's plants and fresh gatherings if possible from the uriginal locality are required. When the dwarf forms are not connected by intermediates with normal plants, there is great difficulty in ascertaining from which species they are derivel. The distribution of the cryptostomata and the nature of the receptacles (if present) give the most hopeful clues, whilst a careful study of the ecology of the plants should aid the elucidation.

In Clew Bay var. balticus is usually found on the sides of narrow channels and creeks on flat peaty areas. The flat surface of these areas is commonly carpeted with var, muscoides, which grows tlensely crowded rogether, and is of a short bushy habit. At the margins where there is nore space, the plants are longer and hang down. These marginal forms I refer to var. balticus. The fronds are narrow, 3-4 inches long, slightly or not at all twisted, and with cryptostomata for the most part marginal. They usually lie in the channels, and are thus in contrast to the upright-growing muscoidcs. The receptacles are small, seldom measuring nore than $8 \times 5 \mathrm{~mm}$. and often less; they are dioecious, not markedly uncilaginous, with non-projecting paraphyses. Male receptacles are more frequent than female, but both are

i $F$. volubilis is, without question, a curious salt-marsh variety of $F$. vesiculosus ; and when the systematic aspect of the British Fucaceae is next dealt with, it will have to be placed under that species. 
rare; the oogonia appear to develop normally. The largest specimens of var. baltious noted were found on a little piece of wet marsh at Leenane (growing here on the flat as well as the vertical banks) - a fact which gives support to the view that soft ground and a large amount of moisture favour its development.

From the above it will be seen that the var. balticus of Clew Bay approaches very closely to the smallesi forms of var. volubilis as described by Baker. At Mersea Island, howerer, receptacles are only found on the large plants ; and the fronds are always much twisted. At Blakeney small plants fruit; but the receptacles are much larger than in the Irish specimens. In hoth these localities there is much mud; and the plants are free, or more or less imberded. In Clew Bay the substratum consists of firm peat, and mud is absent.

Tar. muscoides, var. nov., ${ }^{1}$ Plate VI, figs. 1 and 2.-Plants very short, fastigiately branched, densely crowded together, 5-6 cm. long. Branches cylindrical or compressed, $1-3 \mathrm{~mm}$. wide, not twisted, with marginal creptostomata. Recentacles very scarce, minute, 2-4 mm. diam., dioecious, paraphyses not projecting.

Habitat.-On firm peat, near extreme high-water mark.

With some reluctance I describe this Fucus as a new variety of F. cesiculosus. It approaches in form some of the Baltic filiform varieties of this species; but it differs in its peculiar habitat, and appears to be worthy of a special name. At the same time, thongh the evidence points to its being a rariety of $F$. vesiculosus, the fact is not proved. By giving it pro tem. specific rank, complications in the future are less liable to occur; but this would necessitate the record of an additional new species in the list of novelties; whereas the plant is almost certainly merely a remarkable variety of an already known plant.

As previously stated, var. muscoides is connected with the Clew Bay form of var. bulticus, of which it may be regarded as a very dwarf upright-growing form with filiform branches. The plants are packed very closely together, and form a dense mossy carpet, a feature which serves to distinguish the present variety from the filiforn plants found in the Baltic. In a general Way, the more closely packed the plants are, the smaller and more terete the fronds. The cryptostomata are conspicuous, and are, of necessity, marginal. The fastigiate branching is characteristic; but the branches are often very irregularly produced, and a crop of lateral proliferations is not infrequent.

\footnotetext{
${ }^{1}$ Frondes perpusillae, dense caespitosae, filiformae vel compressae, 5-6 cm. longae, 1-3 mm. latae, crTptostomatibus conspicuis, receptaculis rarissimis, minutis, ovoideis $2-4 \mathrm{~mm}$. latis. Ad terram turfosam.
} 
Receptacles are only known in the wider forms of the plant; they are unisexual, and apparently normal even in the smallest examples, ripe antheridia being noted in a receptacle only $2 \times 2 \mathrm{~mm}$.

The chief reasons for regarding var. muscoides as a form of $F$ vesiculosus, are the unisexual conceptacles and the fact that it is clearly linked with var. balticus. It is true the specific identity of the latter is not quite certain; but the nature of its conceptacles precludes the possibility of its being a form of $F$. spiralis. The only other species with which var. balticus or var. muscoides could be connected is $F$. ceranoides, but as seen growing there is nothing suggestive of any link with the dwarf forms of that plant. A hybrid origin is possible, but scarcely probable, since var. muscoides occurs in profusion where $F$. cerranoides is completely absent. The principal objection to its being a variety of $F$. vesiculosus is its elevation on the shore (above $\boldsymbol{F}$. spiralis and Pelvetia); but this, as pointed out in the ecological section, can be explained by the high water-content of the substratum.

\section{Ascophyllum nodosum var. Mackaii, comb. nov.}

From the historical standpoint this is one of the most interesting of the Irish seaweeds. It was first described from the Roundstone neighbourhood by Dawson Turner in 1808 ("Hist. Fuc." Pl. 52), and is the earliest algal record from that well-known locality. It still occurs in profusion at Roundstone, being found in September, 1911, between the bridge and Ballinahinch. The plant cannot be certified from any other station in Ireland, and, with the exception of a few localities in W. Scotland, it is unknown elsewhere in the Iritish Isles. Turner's remarks will, therefore, be of interest. He states :-

"For the present very interesting addition to the Catalogue of British Fuei we are indebted to Mr. James Townsend Mackay, to whom I am also obliged for the specimen here figured, and by whose name I have ventured to call it, as I find no description of it in any preceding author, in memory of the services that he has rendered to the botany of these islands, particularly by his discoveries in Ireland, the south-west districts of which, a part hitherto least known to naturalists, he has more than once, under the auspices of Dr. Scott, explored with extraordinary zeal and success. It was in one of these excursions, in the summer of 1805 , that he met with the plant here figured, in a small creek at the upper end of Birtebui Bay, near the hill of Cahil, Cunnamara, but nowhere else. He informs me that he could not find a single specimen attached to the rocks, but it was all lying in loose balls upon the shore, and in such quantity as to entirely cover that part of the strand upon which it was thrown. With it was $F$. nodosus, which, though produced in great abundance upon rocks in the neighbourhood, seemed to exist at that place only in a similar manner, without being fixed to anything; both of 
them being rolled up as if by the action of the waves, and in that state apparently continued to grow, and throwing out from the root, which was in the centre, a prodigious number of shoots in all directions, so as to give the thick and bushy appearance above described."

There can be no doubt that the present plant is merely a variety of A. nodosum, and is comparable to the peculiar detached forms of Fucus and Pelvetia which occur in other localities. (See Baker, '12, p. 283, and Oliver in Tansley, "11, p. 36t.) Whether it originates in the manner described below for var, scoipioides I was unable to decide, but it appears highly probable. No intermediates between the detached form and the normal $A$. nodosum were found, but there was an evident link with var. scorpioides, and certain specimens rere difficult to place. It is possible that the variety Mackaii arises only at certain seasons of the year, in which case a prolonged stay in the locality might be necessary in order to discover its origin.

The plants lie as loose densely branched tufts (up to a square yard in area) on the flat sandy mud between patches of rock, and when the tide returns they do not float, but become perfectly submerged. They appear to be seldom disturbed by wave-action. Air-bladders are numerous, but very small. A few tufts of Polysiphonia fastigiata were noted on some specimens, and also on var. scopioides; but on the whole this epiphyte was absent. Many quiet land-locked areas exist in Achill Sound and Bellacragher Bay; but no examples of rar. Mrickcii were found, so that the Roundstone locality still remains the only positive station in Ireland for the plant. ${ }^{\text {}}$

Although C. Agardh, as early as 1824 , reduced Fucus Machaii to a variety of $F$.nodosus, no one appears to have used the combination employed in the present report. Of late years there has been a tendency to follow Harvey, who regarded it as a distinct species. Holmes and Batters ('90) removed the plant to Ascophyllum; and their name, A. Mackaii, has since come into general use.

Var. scorpioides Hauck.-A few plants of this curious variety occurred in some muddy areas in the inner part of Roundstone Bay intermixed with var. Mackaii. They were more or less imbedded in the mud, and formed much smaller tufts than the latter. Reinke's explanation as to the origin of this form in the brackish waters of the Baltic Sea is as follows:-Isolated floating pieces of $A$. nodosum are washed in by currents from the more open Skagerack, and come to rest in the quiet creeks, where they put forth numerous small adventitious branches from the marginal cryptostomata of the thallus.

' Miss Knowles kindly informs me that specimens labelled A. Mackaii, collected in Larne and Belfast Loughs by D. Moore and J. Doran respectively, exist in the Dublin Museum. There is, however, some uncertainty as to both specimens, and though the districts have been fairly carefully worked, other observers have not noted the plant.

R.I.A. PROC, VOL. XXXI, 
Through the growing out of such branches and the decay of the old fronds, colonies of young plants arise, which lack a discoid base, the latter being only produced by sporeling plants. The cylindrical form of the branches, the absence of air-bladders, and the complete sterility are induced, according to Reinke, by the low salt-content of the water; and he suggests that in less brackish localities such floating shoots of $A$. nodosum might give rise to A. Mackaii. (See Reinke, '89 and '92.)

\section{Bifurcaria tuberculata Stackh.}

It appears probable that the Roundstone neighbourhood is the northern limit in the British Isles for this species. It occurs on the coast of southern England, and is known in Ireland from the counties of Cork, Clare, and Galway, being abundant in the last-named at Dog's Bay. The pools of Clare Island, and the more open parts of Clew Bay, which are eminently suited for it, were carefully worked, yet not a single plant was observed.

\section{Taonia atomaria J. Ag.}

Dredged in Clew Bay, and washed ashore between Old Head and Leckanvy (1909, '10, '11). Frequent on the west coast and known as far north as Bundoran (Johnson); on the east coast it has been collected at Wicklow (Harvey).

Dictyopteris membranacea Batt. (= Haliseris polypodioides Ag.).

In contrast to Bifurcaria, an extension of distribution can be recorded for this southern species, Roundstone Bay having hitherto been its northern limit. Several specimens were dredged in Clew Bay by Mr. J. Adams, in August, 1909 ; but the plant was not seen again during the Survey. The specimens were large and strong; and the species is evidently quite at home as far north as Co. Mayo.

\section{Erythrotrichia Bertholdii Batters.}

Useful notes on the genus Erythrotrichia will be found in the paper by Batters, in which this species is described ('00, p. 374). The cylindrical filaments resemble those of E. citiaris (Carm.) Batt. (non Thur.); but the plant is distinguished from that species by the absence of a basal disk.

Achill Sound, October, 1910, on old Zostera leaves.

\section{E. investiens Born.}

With slight hesitation I have referred a few odd filaments found at old Head to this little-known species. The plants fit no other species of the 
genus, and agree well with the description given by Zanardini. The filaments are bright rose in colour, rather thick ( $25-35 \mu$ when sterile), and unbranched. There is no true basal disk; but a few horizontal cells are developed at the base, and the filaments occur in tufts, as shown in Zamardini's figure; lateral mamillose protuberances as described by him are also present. The specimens were found on Fucus (possibly attached to it), and agree well with Haucke and Richter's Exsicc., No. 655 (also on Fucus), which Batters suggests should be referred to $E$. investiens rather than $E$. ciliaris ('00, p. 374).

\section{E. Welwitschii Batters.}

This little-known and apparently very distinct species was found on limpetshells encrusted with Ralfsia cernucosa near low-water mark, in October, 1910. The plant was originally described by Ruprecht as Cruoria (?) Welwitschii, and the same specimens were later referred to by J. Agardh as Callithamnion lepcedicola. Batters (102) removed the plant to its right genus, and made the new combination Erythrotrichia Welwitschii. A portion of the Lisbon gathering, collected by Welwitsch, exists at Kew, with which the Clare Island specimens agree well.

The species appears to be confined to the thalli of Ralfsiae, and is worthy of further study. Hitherto it has been recorded in the British Isles from Swanage only; but it is probably widely distributed. When wet it is inconspicuous; but when the limpet-shells are becoming nearly dry, it shows as a pale-pink felt.

\section{Porphyra coccinea J.Ag.}

Somewhat rare, and not previously recorded for Ireland. I noted it, however, in Co. Antrim in May, 1910; and a specimen collected by Miss Hutchins, from Bantry Bay, was found unmamed in the Kew collections.

\section{P. umbilicalis Kütz.}

Tar. umbilicalis J. Ag.-The exposed Porphyra association, described on p. 28, consists entirely of this form.

Tar. laciniata Thur,-Abundant throughout the area, being saxicolous or epiphytic, and occurring in the littoral and upper sub-littoral regions, and also in pools. It is the variety which forms the Porphyra association of sheltered localities.

Var. linearis Harv. $(=P$. linearis Grev, in Batters '02, p. 56; see Iinsenvinge, '09, p. 61).- - Unless the growth of the plants be watched from month to month, $P$. linearis Grev. would never be taken to be the same species as $P$. umbilicalis Kütz., especially as sporelings of the latter often 


\section{Proceedings of the Royal Irish Academy.}

develop directly into broad frondose thalli. I fully agree, however, with Thuret and with Rosenvinge, who regard $\boldsymbol{P}$. linearis as a young and winter form of $P$. umbilicalis. Observations made at Swanage, though not so extensive as those of Rosenvinge, led to that conclusion. On exposed coasts a very large proportion of the growth does not survive the spring. On the more sheltered shores of Clew Bay the plant doubtless develops, as it does at Swanage, into var. laciniate. A typical band of $P$. linearis was, however, only observed on the exposed parts of the Clare Island district.

\section{CHANTRANSIA.}

The species of this genus have been very erroneously named in the past; and it is highly satisfactory to have had the Survey material named by Dr. Rosenvinge. The following account is derived from his report:-

The epiphytic covering of Chantransia, which is conspicuous on many algae on Clare Island, appears to consist almost entirely of various varieties of $C$. virgatula. In sheltered localities (e.g. Clew Bay and Achill Sound) the same species is abundant; and $C$. Thuretii also is exceedingly common. It will be noted that in his work on the Dauish species ('09) Rosenvinge places $C$. secundate and $C$. Iuxurians (which are given specific rank by Batters ('02)) as varieties of $C$. virgatula.

\section{C. virgatula Thur.}

Var. luxurians (J.Ag.) Rosenv,-Common and very conspicuous on Ceramium spp. in rock-pools at Kinnacorra and Portlea (Clare Island). On the mainland it was found on Gracilaria and Zostera dredged in shallow water. New to Ireland.

Var. tetrica Rosenv.-This variety, which is also new to Ireland, occurred on Codium tomentosum on Clare Island, and on Gracilaria at Old Head. It is distinguished by the presence of tetraspores on short opposite branches.

Var. secundata (Lyngb.) Rosenv,-Exceedingly abundant in all parts of the Survey area. On Clare Island it is the form which gives the pink colour to the growth of Porphyra on exposed rocks; and it is also found on the Rhodymenia and the Laurencia pinnatifida communities. The plant moreover covers Codium and Ceramium spp. in pools, and can endure a certain amount of fresh water, being found in the spray of the waterfall at Portlea. On the sheltered mainland it is common on many algae, both in the littoral and sub-lititoral regions.

\section{Thuretii (Born.) Kylin.}

Though a new record for the British Isles, this species is common in Britain, and has doubtless been passed over as $C$. Dociesii. It is distinguished 
from that plant by its more slender filaments, which are composed of very long cells, and by the occasional occurrence of sexual reproduction; but Rosenvinge remarks that he is not yet certain if the two are sufficiently distinct to be kept apart. C. Thuretii appears to be a species of quiet waters, being abundant in Clew Bay and Achill Sound, but only collected once on Clare Island and then in pools at Portlea. It is especially plentiful on Zostera, and is most conspicuous in late summer.

\section{C. endozoica Darb.}

A species of Alcyonidium washed ashore at Old Head was infected with a Chantransia apparently referable to this species. Dr. Rosenvinge writes that the parts are smaller, and that the fertile branches are less branched than in Darbishire's plant.

\section{Alariae Jons.}

Noted ou several occasions on old fronds of Alaria which had been washed ashore. It extends at times over a very considerable area of the lamina.

\section{Nemalion elminthoides (Velley) Batters.}

Velley's figure (in Withering, "Bot. Arrang.," ed. 2, vol. iii, p. 255, pl. xvii, 1792 ) is unmistakable, and it is confirmed by his specimen in Herb. Kew; his name, therefore, is rightly adopted by Batters in favour of the more familiar 1. lubricum, 1830. Velley's plants were collected at Portland Bill in (or previous to) 1792 , and it was interesting to observe in July, 1911, that the plant still grows there in profusion.

A more difficult matter is the separation of this species from the wellknown $N$. multifudum, described by Weber and Mohr in 1804. Ecological observations on Clare Island (p. 37) and elsewhere increase the suspicion that the two may be forms of one species; but the point requires detailed study. Interesting notes on the protonemoid stage of Nemalion and its biology are given by Chester (Bot. Gaz., xxi, p. 340) and by Rosenvinge ('09, p. 144).

\section{Scinaia furcellata Bivona.}

Found during the first year of the Survey only by J. Adams whilst dredging off Mulranny in about 7 fathouns (August, 1909). Distribution in Clew Bay probably local.

Gelidium aculeatum Batt. (= G. corneum var. aculeatum Grev.).

Having no personal knowledge of the value of characters in Gelidium, I follow Batters, who raises this plant to specific rank. It thus figures as an 
addition to the Irish flora; but it is not unlikely that it has often been collected as a variety of $G$. corneum, though no record of the fact has been found.

\section{Phyllophora Brodiaei J. Ag.}

A boreal species. Not previously collected on the west coast, but known from the north of Ireland, Scotland, and northern England.

All the specimens labelled $P$. Brodinei from the south of England in the Kew and British Museum herbaria are misnamed, being forms either of $P$. pulmettoides or $P$. mubns, and there is little doubt that the same applies to other south coast records (cf. Batters, '02, p. 65).

\section{Callymenia Larterae Holmes, Journ. Bot., '07, p. 86.}

Several plants washed ashore on Clare Island in October, 1910, have been determined by $\mathrm{Mr}$. Holmes as belonging to this species. The plant is characterized by the tapering loase of the frond and its repeated proliferous branching. It has doubtless been overlooked in the past as a variety of C. reniformis.

Gracilaria confervoides var. procerrima (Turn.) Batt.

Amongst the many forms assumed by this species, this variety is one of the most distinct. It is doubtless the same as Harvey's variety longissima, of which he remarks: "Var, $\beta$ is often 6 feet long, and quite simple, or with a few short lateral ramulae. Its peculiarities appear to result from its place of growth (Charlestown Harbour, Rhode Island), and intermediate forms connect it with the ordinary much-branched rarieties." The Irish species confirm Harvey's opinion. They were dredged in Clew Bay, though some fine specimens 5 feet long were gathered by hand in the channels in Achill Sound. 'The amount of branching raries considerably; but the short subulate ramulae are almost constant. Probably common in Ireland, but no record found.

\section{Nitophyllum uncinatum J.Ag.}

This species is usually regarded as synonymous with $N$. laceratum var. uncinatum-an error which is due to the citation of a false synonyn in the original description. 'The plant was described by $J$. Agardh in 1852. He states that it is not uncommon in the Mediterranean, and was characterized by the possession of actuminate fronds and of occasional uncinate branches; the sori were proluced immediately behind the apex of special short branches. Unfortunately, Agardh quoted $N$. laceratum var. uncinatum, which is a 
perfectly distinct plant, as a synonym. I have already pointed out this confusion (Kew Bull., 1909, p. 242); but the following notes, based on olservations at Plymouth and in Clew Bay, deal with the subject in greater detail.

Taking first $N$. laceratum, we find that the variety uneinatum is directly connected with the ordinary forms of this common plant. $N$. lacerutum is (with very rare exceptions) the ouly species found in rock-pools on open shores, and, though it exhibits great variety of form, there is usually no difficulty in the specific identity of the plant, the iridescent fronds of a pale brick-red or dull purplish-red colour being very characteristic. The uncinate form is not uncommon in pools, being found from early summer till autumn; it appears to be connected with a more or less vertical habit and contact with other algae, being usually found clinging to Corallina. The hooks may be few or numerous, and terminal or apparently lateral. 'I'he form of the frond is very variable, often lobed or bluntly pinnate, but never possessing the definitely acuminate branches of $N$. uncinatum (Plate X, fig. 11).

When $N$. laceratum occurs in the sub-littoral (1-7 fathoms), the form of the thallus differs somewhat, being longer and more or less regularly dichotomous; but the iridescence and characteristic dull colour are maintained. Uncinate specimens occasionally occur; but, except for increased length and greater regularity, they differ little from the rock-pool form. They are clearly connected with the normal plant. Tetrasporic sori are frequent; these are found, as is characteristic of the species, either in special proliferations or along the margins of the fronds.

N. uncinatum. J. Ag, is, on the other hand, a plant confined to the sublittoral region, and, though abundant in Clew Bay, is less generally distributed and apparently very local. It is found in late summer and autumn, being washed ashore in profusion in August, Septemher, and October, in 1909, 1911, and 1910 respectively. It is distinguishable at once by its deep erimson or crimson-lake colour, and lack of iridescence. Most often it is attached to the stems of Laminaria Cloustoni; but it is found on various stiff algae such as C'ystoseira, Gracilaria, etc., and by means of its hooked branches is entangled with loose weeds of all kinds. The acuminate character of the branches is always noticeable, but is most marked in young plants. The hooks are formed at the termination of the shoots, but not infrequently new branches grow out below the apex and take on the function of the main shoot so that the growth is sympodial (Plate X, fig. 10). The same course of development probably accurs in $N$. laceratum var. uncinatum; but if this be the case, the sympodial growth is more perfect, as the uncinate branches appear merely as small lateral hooks (Plate $\mathrm{X}$, fig. 11). Cystocarps are unknown in $N$. uncinatum, but 
tetrasporic sori are not infrequent, being produced in special short branches. The plant is very closely allied to N. reptans Crn.; and it is doubtful whether they are really distinct. I have not had the opportunity of examining a good series of the latter plant. For an account of the anatomy and physiology of algae with uncinate branches see Nordhausen ('99).

To sum up, the deep colour, lack of iridescence, and acuminate branches clearly mark this species, whilst its sub-littoral habit and obviously terminal hooks also aid in separating it from the uncinate form of $N$. laceratum. It is, however, allied to that species; and they have this feature in common, that they are both liable to be infecter with the parasite Gonimophyllum.

\section{Bonnemaisonia hamifera Hariot.}

The discovery of Bonnemaisonic hamifera on the west of Ireland raises doubts as to whether this alga is not after all indigenous to Europe. Originally described from Japan, it has been usually regarded as a plant introduced to the south coast of England. It was collected by T. H. Buffham at Falmouth in 1895, and was subsequently found at Torquay and Shanklin (Isle of Wight). The Rev. H. Boyden tells me he has gathered it within the last few years at several widely separated localities in Cornwall (West Looe, Falmouth, and Penzance); and I have noted it for some five or six seasons in rock-pools at Weymouth. Chalon lists it from Cherbourg on the other side of the Channel, but it is not known elsewhere in Europe. It is locally frequent, but never abundant.

With regard to Clare Island it was with some astonishment that several fronds of the plant were emptied out of a tube of mixed algae collected at Kinnacorra in June, 1910. In October of the same year, and in April of the next, the locality was specially searched, but no further specimens were found. During August, 1911, however, one or more loose fronds were noted in Achill Sound, Roonah Point, and Clare Island, so that there is no doubt whatever that the species occurs in the district (see p. 165).

\section{Laurencia hybrida Lenorm.}

Although our three British species of Laurencia are perfectly distinct, considerable confusion exists with regard to the present species, which is usually found in herbaria, not only under the names of L. hybride and $L$. caespitosa, but also on the same sheets as $L$. pinnatifida and L.obtusa. The plant is poorly described in most of our floras, and the confusion is increased by a difficulty as to narnes.

Nomenclature.-The name to be used is clearly L. hybrida (DC.) Lenorm. Fucus hybridus was described by De Candolle in 1805 ("Flore Française," ii, 
p. 30). It was transferred to Laurencia by Lenormand in 1830 (Duby, Bot. Gall., p. 951); and his name has been used by Kützing, J. Agardh, Le Tolis, and De Toni. Dawson Turner in 1808 named the plant L. pinnatifida ral. angusta, giving a figure (Synopsis, Pl. 20, fig. $f$ ), and quoting L. hybrida as a doubtful synonym. Turner's name was adopted by Greville (who gires an excellent figure), Hooker (Brit. Flora), and Harvey (Manual Ed. I, p. 69, and Phyc. Brit., Pl. 55). The ideas of these writers as to the plant were not very exact, and they confused it with narrow forms of $L$. pinne fifide. A third name (and one which has been largely used in this country) is $L$. ccespitose Lamx., which dates from 1813. This, however, was a nomen mudum, and was moreover reduced to a synonym of L. dasyphylla by C. Agardh in 1822. But in 1840 it was taken up by Montagne (for a plant which he afterwards decicled was a new species, L. canariensis, Pl. Crypt. Can., p. 154, and Kütz., Spec. Alg., p. 85̆t), and was used by Harvey in the second edition of the Manual and also in Phyc. Brit. (Pl. 286). Our plant, therefore, figures in the latter work under two names; and Harvey himself admits doubts as to the species. J. Agardh, at a later date, examined some of Lamouroux's specimens, and redescribed what he considered the true L. caespilosa Lamx.; the identity of this plant is, however, doubtful. Though most of the older writers confused the species with narrow forms of $L$. pinnatifida, the plant they had in mind is perfectly clear, both from their descriptions and from specimens in herbaria. Some have used one name, some another. The name hybirida (1805) has priority orer caespitosa (1813), which, as we have seen, was merely a nomen nodum till 1840. There is no question that the plant is distinet from $L$. pinnatifida.

Description and Habitat.-L. hybirda is alundant on the British shores and forms part of the Gigartina-Lamrencia association of exposed coasts, but it is also frequent in rock-pools. It may always be distinguished from $L$. pinnatifude by the constantly cylindrical fronds and its pyramidal outline. The small size, greenish colour, and caespitose habit are also noteworthy, whilst its marked winter growth and absence in summer are quite characteristic. Small sporelings 2-3 mm. high are discernible in September ; these develop during autumn and winter, and fruit in early spring. By May the plant begins to disappear, and is not seen again till September or Octoler. When growing on bare rocks which are left dry by the tide, the plant is very compact, and seldom more than 1-2 inches high; but in shallow pools fully exposed to the light, it is more lax, and may attain a height of 4-5 inches. In autumn and winter L. hybrida is a dark greenish purple; but with the advance of spring the purple hue 
disappears, and the plant assumes a green colour, pale when growing in sunny pools, but darker when on bare rocks or under the shade of other plants. It should be noted that $L$. pinnatifida also reaches its maximum development in spring; but it is present more or less throughout the summer, and appears to possess a persistent base (see p. 35).

L. hybrida has been also confused with $L$. obtusa with which it agrees in possessing cylindrical fronds. The colour and habit of the two are, however, very distinct. $L$. obtusa is a sub-littoral plant of dark red colour which becomes yellow with sunlight. It is also found in pools and shallow water, especially in winter and spring, and is almost always epiphytic. There is further an important morphological distinction to be noted in the structure of the antheridial conceptacles. The conceptacles of $L$. hybrida will be found to resemble those of $L$. pinnatifida, and to be quite distinct from $L$. obtusa (see Falkenberg, '01, pp. 242 and 249).

The distribution of the present species is more restricted than that of the other two. It is common in England, Scotland, and Ireland, and is found on the north and west coasts of France; but I have not seen undoubted specimens from other countries. The records from the Mediterranean, Ceylon, Japan, and the West Indies require verification. The antheridial character referred to ahove will possibly aid in the identification of this species, since in Laurencia exact similarity of form cannot be insisted upon when climatic conditions are different.

\section{Polysiphonia macrocarpa Harv.}

First described by Harvey in Mackay's "Flora Hibernica," part ii, p. 206. It was wrongly united in "Phyc. Brit." with $P$. pulvinata, but is rightly presented in Batters (02). Amongst British species it is very distinct; but Bornet suggested that it might be a form of the Mediterranean $\boldsymbol{P}$. sertularioides, though in his "Algues Schousboe" he preferred to keep them apart. $P$. macrocarpa usually grows in shallow crevices near low-water on exposed rocks, being not uncommon on Clare Island, and the only species of the genus noticed on The Bills.

\section{P. fastigiata Grev.}

Though usually confined to Ascophyllum nodosum, it is interesting to note that in exposed localities (where that plant is absent) $P$. fastigiata is frequently found on Fucus spiralis. In a general way $F$. spiralis on exposed rocks on Clare Island is free from the epiphyte; but at Alnahaskilla scores of infested plants may be counted. $P$. fastigiata was noted on the same host at other spots on the island, and in one case it occurred on $F$, vesiculosus, 
P. subulifera Harv.

This rather rare species is apparently frequent in the west of Ireland, being found abundantly in Clew Bay, Achill Sound, and also in Roundstone Bay. Harvey notes its frequency on the Lithothamnium banks at Roundstone; and in September, 1911, it was the dominant species. It was also dredged on similar ground in Clew Bay, and appears to be one of the Florideae which can withstand considerable insolation in shallow water.

\section{Dasya arbuscula $\mathrm{Ag}$.}

The frequency with which this plant is met with in Ireland at once strikes the collector as a great contrast to the south of England, where, though found from Land's End to the Isle of Wight, it is always rare. Harvey (Phyc. Brit.) notes its abundance at Bantry Bay, and on Clare Island it may be regarded as one of the most frequent and constant of the miscellaneons collection of Redweeds that occur near low-water mark on moderately exposed rocky shores (e.g. Kinnacorra). At certain seasons also it is washed ashore in plenty (July, August?).

\section{Ptilothamnion lucifugum sp. nov. ${ }^{1}$ (Plate IX).}

Plants gregarious, minute, $1-1.5 \mathrm{~cm}$. high. Fronds decumbent at the base, then erect, producing branches and pinnae irregularly. Branches 3-6 $\mathrm{mm}$. long, irregularly beset with pinnae; cells, $35-50 \mu$ wide, by $3-4$ times as long. Pinnae short, 2-3 mm. long, opposite, but more often irregular, usually naked below, but bearing above regularly opposite forked pinnulae; cells $25-30 \mu$ wide by $1 \frac{1}{2}-2$ times as long. Pinnulae bifid through the production of a lateral branch on the under side of the lowermost cell, rarely simple, very rarely trifid; cells $15-20 \mu$ wide by $1 \frac{1}{2}-2$ times as long. Decumbent portion of the frond irregularly attached to the substratum by rhizoidal pimnae, which occasionally terminate in a discoid expansion. Tetraspores and cystocarps unknown. Antheridia borne on the terminal cells of the pinnulae.

Habitat. - Attached to rocks in shallow pools in a dark cave, Portlea, Clare Island, August, 1911.

Closely allied to P. micropterum (Mont.) Bornet, but distinguished by its irregular branching, larger size, and peculiar habitat.

The present species was found as a dense mossy covering on the bottom

1 Frondes caespitosae, $1-1.5 \mathrm{~cm}$. altae, ramis primariis repentibus secundariis erectis. Pinnae 2-3 mm. longae, pinnulis omnibus furcatis aut rare simplicibus. Articuli ramorum 3-4plo pinnarum 1-2plo diametro longiores. Sporangia et eystocarpia ignota. Antheridia in articu!o terminali pinnularum evoluta. Hab. In spelunca.

Species P. microptero proxima sed frondibus majoribus irregularibus differt. 


\section{Proceedings of the Royal Irish Acudemy.}

of a dark cave-pool during the last day spent on the island; owing to-its minute size, it was difficult to secure, the plants on detachment being easily lost in the water. No tetrasporic or cystocarpic plants were obtained, but sufficient material was collected to show general characters. The plant is closely allied to $P$. micropterum, which was described by Montagne from the Canary Islands. Sauvagean also collected it on Cystoseira at Gúethary, and in recording the same, adopterl a suggestion by Bornet, and removed the plant from Callithamnion to Ptilothamnion (Sauv., '07, p. 206). Monsieur Hariot kiudly allowed me to examine the Canary Islands type from the Paris Museum; and it was found to consist of a smaller and much more compact plant, probably of epiphytic habit. The Gúethary specimens appear to have heen mislaid. Reinsch's $C$. pinctroides (suggested as a synonym in De Toni, Syll. Alg, iv) is certainly distinct; but Hauck's C. pluma from Trieste (Beiträge, vii, 1878, p. 131) proves, on examination of the specimens kindly lent me by Madame Weler, to be $\boldsymbol{P}$. micropteron. No other record exists. As $\boldsymbol{P}$. micropteron is so very little known, it is within the bounds of possibility that the Irish plant is an extreme form of that alga; but taking all things into consideration, it appears wiser to regard it as a distinct species.

Spermothamnion Turneri var. subverticillatum cumb. nov.

Callithamnion Turneri var, subverticillatum, Lenorm. Ms., in Herb. C. subverticillatum, Zanard, in Kütz. Tab. Phyc., xi, tab. 81 ?

The specimens referrel to this variety agree precisely with plants so named by Lenormand in the Kew Herbarium. C. subverticillatum Zanard. is most probably the same plant, but apparently Zanardini's specimens were not kept, as the plant is not listed in De Toni's catalogue of his herbarium. The variety differs from the ordinary form in the elongated slender shoots, and in the sub-verticillate branching. In Clew Bay it was found on several occasions, but always in a floating condition. As seen thus it is very distinct, and would appear to be a good species, as Zanardini believed; but whether the characteristic habit is due merely to growth subsequent to, and resulting from, detachment was not ascertained. Until this can be determined, and the question of Zanardini's plant inquired into, it appears best to regard the alga as a variety.

\section{Griffithsia corallina Ag.}

Occurs in the greatest profusion during spring in Clew Bay and Achill Sound. It is largely epiphytic and is found in channels and in shalluw water. 
Beautiful specimens, perfectly spherical in form and sometimes as much as $20 \mathrm{~cm}$. in diameter, may be seen floating in with the tide during May. No plants were noted in the rock-pools on Clare Island.

\section{Bornetia secundiflora Thur.}

Bornetia is one of the most interesting additions to the Irish flora. It is abundant in the Mediterranean (south France), and common in the Biarritz neighbourhood. It extends up the Atlantic coast as far north as Normandy and Brittany, and is found as a very rare plant on the shores of Devon and Cornwall. Two fine plants were collected in a deep pool on Clare Island, in July, 1909, and though neither bore mature fruit, there can be no doubt as to their identity. The pool was searched on each subsequent visit; but, with the exception of a small frond found in August, 1911, no further specimens were observed.

\section{Callithamnion byssoides Arn.}

'The specimens referred to this species agree well with those from Devonshire collected by Mrs. Griffiths, and with the plant as generally understood in this country. In general habit it bears a very close resemblance to $C$. corymboso, and even with a lens it is not easy to separate the two. The distinctive feature is the irregular pinnate branching, which connects it in the other direction with $C$. roseum. From the latter it is marked off by the very much more slender growth, and by the tetraspores being usually single on the pinnae. The form of the cystocarp is also different.

C. byssoides is common in Clew Bay and Achill Sound (as a spring and early summer plant), occurring as an epiphyte on various algae in the low-littoral and sub-littoral region. It is very closely allied to, if not identical with, C. Furcellariae of the Swedish botanists.

\section{C. scopulorum Ag.}

I follow Börgesen in regarding this plant as a distinct species, which differs from $C$. polyspermum in its dwarf size, absence of cortication, and saxicolous habit. It is abundant on Clare Island, on moderately exposed rocks, but, owing to its minute size, is not conspicuous.

\section{C. arbuscula Lyngb.}

An alga belonging to the boreal group, but abundant on Clare Island. Tt apparently occurs on all the Irish coasts, but is quite absent on the south of England (see pp. 164 and 169). 


\section{Callithamnion corymbosum Lyngb.}

Very abundant in spring and early summer, and found probably throughout the whole year. It was plentiful in October, 1910, at Achill Sound; and numerous young plants were dredged in Clew Bay the following February.

\section{C. granulatum Ag.}

When Harvey dealt with C. spongiosum in "Plyyc. Brit." he suggested the possibility of its being united with $C$. granulatum Ag. In 1851, J. Agardh carried out this prediction, and his view has been generally accepted. There are, however, two very distinct forms. One, which occurs in the $C$. arbuscula association, is compact, densely branched, and turns a pale greenish-yellow in summer; and the other, which hangs from vertical rocks in company with Plumaria elegans, is larger, less compact, and does not occur in sunuy places. The former agrees in habit with the Mediterranean $C$. granulatum; and the latter is undoubtedly Harvey's $C$. spongiosum. The matter requires careful investigation, as it appears possible that Harvey's plant may after all be a good and distinct species. Both forms occur in Clare Island, and no intermediates were seen.

\section{Ptilota plumosa Ag.}

This species, which is said to occur all round the Irish coasts, is perhaps the most noteworthy of the boreal algae that are found on the west of Ireland (see pp. 165 and 169).

Antithamnion crispum Thur. in Le Jolis" "Liste," p. 112.

(A. Plumula var. crispum J. Ag., Batters, Cat., p. 89.)

This plant is distinguished from $A$. Plumula by its short recurved pinnae and thorn-like pimnulae. It is widely distributed, and often occurs where A. Plumula is absent (i.e. in the Adriatic; see Krasser in Zahlbruckner, Krypt. Exsicc., No. 648). Batters follows Agardh, who regards it as a variety; but the views of Thuret, Krasser, and others appear warranted. The true A. Plumula was not found in Clew Bay, and the Bantry Bay species in Herb. Kew are also referable to $A$. erispum.

\section{Ceramium Boergesenii Petersen.}

D1. H. Petersen, who is at present investigating this genus, kindly undertook to examine my material. To him is due the discovery of this, and the following addition to the flora of our islands. C. Boergesenii has doubtless been passed over as a form of $C$. decurrens, to which it is very closely allied. 
It is chiefly distinguished by the corticating cells which grow upwards as well as downmards from the nodes. Frequent in our district, being found especially on the receptacles of Himanthalia on Clare Island.

Distribution.-Iceland, Faeröes.

\section{C. atlanticum Petersen.}

A pretty little species, described by Petersen, from Iceland and the Faeröes. On Clare Island a few specimens only were found. It apparently enjoys open conditions, being collected on exposed rocks and on The Bills

\section{C. rubrum $\mathrm{Ag}$.}

Dr. Petersen distinguishes the following forms in my material of this perplexing species :-

(a) prolifera-secundata, forms typica, secundata, and ivegularis,

(b) pedicellatir-virgata, f. irvegularis.

(c) subtypica-modificata, forms vera and irregularis.

Abundant in great variety of form in all parts of our area.

\section{Gloiosiphonia capillaris Carm.}

Found in several spots on the island during the first year of the Survey only (July, 1909). Not present in the same spots in June, 1910, nor August, 1911.

\section{Schizymenia Dubyi J. Ag.}

This is a distinctly southern plant, being known in England from Devon and Cornwall only. In Ireland it has been recorder from Pelfast Lough, but not from the west or south. Several specimens were noted on Clare Island in May, 1911.

\section{Cruoria adhaerens J. Ag.}

'The distinctive features of $C$. adhaerens are not well known; but relying on the slides in the Batters collection in the British Museum, I have regarded it as being characterized by the possession of short filaments which adhere closely together. The individual cells also are short, but the tetraspores very large.

\section{Cruoriella Dubyi Schm.}

C. Dubyi is the dominant species of incrusting algae in the shallow waters of Clew Bay. It occurs abundantly on sheils and stones at all seasons; and, in the inner parts of the bay, is found occasionally on the stipes of Laminaria 


\section{Proceedings of the Royal Irish Academy.}

Cloustoni; tetrasporic fruits wore collected in February. The flabellate arrangement of the cells on the under-surface of the thallus (a feature which Schmitz makes characteristic of the genus) distinguishes it at once, in our area, from allied plants.

Harvey records C. Dubyi (sub Peyssonnelia Dubyi) as accurring in great profusion in Birturbuy Bay, Roundstone ("Phyc. Brit."); but, as pointed out below, this was an error, since the specimens preserved are those of Peyssonnelia. It is remarkable that in Clew Bay Cruoriella should be dominant, and at Roundstone Peyssonnelia.

\section{Peyssonnelia $8 p$.}

The species of Peyssonnelia accurring in west Ireland must for the present remain undetermined. It was recorded by Harvey as $\boldsymbol{P}$. Dubyi (now Cruoriclla Dubyi); and he states that it is abundant in Birturbuy Bay. Batters ('96, p. 11) showed that Harvey's material consisterl of a genuine Peyssonnelia (the T.C.D., Kew, and Linn. Soc. material was examinerl), and he referred the plant to $P$. rubra Grev., a species originally described from the Ionian islands, and, as generally understood, common in the Mediterranean. Though the genus is correct, the specific identity appeared questionable. From Greville's description, his species is a plant with free-growing lobes, i.e. with the habit of $\boldsymbol{P}$. squamaria; whereas the Clew Bay plant has an attached encrusting thallus, such as is found in $P$. Haveyana. In order to settle the point it was necessary to examine the type in Greville's herbarium at Edinburgh; and through the kindness of Professor Bayley Balfour, it was sent to Kew on loan. The specimens fully confirmed Greville's description and figure, and there is no doubt that the Irish species must be kept distinct. Madame Weber van Bosse, who is engaged in unravelling the tropical species of the genus, informs me that the form of the rhizoids, to which much value has been attached, is an unreliable character. The species of this, and allied genera, have in the past been so poorly described, that it is impossible to be certain if any of them are identical with the present plant. On this account it appears advisable to wait till a monographic work is available. The alga is rare in Clew Bay, and fruits in winter.

\section{Porphyrodiscus simulans Batters.}

On account of its characteristic nemathecia, the genus Porphyrodiscus was founded by Batters for the reception of this plant (Journ. Bot,, 1897, p. 439). He detected it at Berwick in 1889, and apparently it has not been found elsewhere. The Clew Bay specimens were obtained at Annagh Island, on stones in muddy ground near low-water mark, 
Rhododermis polystromatica Batters, in obs., Journ. Bot., 1896, p. 389

(R. elegans var. polystromatica Batters).

The variety polystromalica is so distinct from Crouan's $P$. elegans that it certainly ought to be regarded as a distinct species. Batters himself proposed the combination in 1896 (l.c.) ; but in 1902 he (probably inadvertently) used the older designation.

Choreonema Thureti Schmitz.

A minute species, which requires to be carefully searched for. It has been stated to be common in Ireland, and ta occur on all three species of Corallina; but this is probably an error. On Clare Island it was found only on $C$. squamata (its usual host), although a large amount of $C$. officinalis was carefully examined with a lens. The plant is also known to occur on C. rubens.

\section{MELOBESIEAE.}

The material of this group, as noted above, was examined by Dr. M. Lemoine, who kindly furnished critical observations on the specimens, and also prepared a complete list of the species obtained, together with notes on their distribution. In view of the confusion existing, the general distribution of each species as supplied by her is published in the present report. It will be noted that the nomenclature differs slightly from that employed by Batters.

Attention should also be drawn to the account given by Johnson and Hensman ('99), where analyses of the Knockboy and Bantry Bay sand, together with other details of local interest, are given. Since that date much critical work has been done, and hence seven of the plants listed there as distinct species are in the present report regarded as synonyms or varieties.

\section{Melobesia farinosa Lamx.}

Abundant on Zostera in Clew Bay, and found at all seasons.

Instribution.-General.

\section{M. zonalis Fosl.}

This minute species was dredged in Clew Bay (3-5 fathoms) in February, May, and August, 1911, and is evidently frequent. It occurs on glass, porcelain, and shells. $M$. zonalis belongs to the subgenus Pliostroma, the species of which are characteristic by being polystromatic.

Distritution. - England, Scotland, Ireland, N. France (Brest), Mediterranean (Banyuls). 


\section{Lithophyllum (Dermatolithon) pustulatum Fosl.}

Common on Clare Island, especially on Gigartina and Phyllophora rubens in rock-pools, and near low-water mark. It was also found on Cladophora rupestris.

Var. Corallinae Foslie (Melobesia Corallinae Crouan, Batt. Cat., p. 96).Common on Corallina officinalis in rock-pools on exposed shores.

Var. Laminariae Foslie ( $M$. Laminariae Crouan, Batt. Cat., p. 97).-Not uncommon on stipes of Laminaria Cloustoni.

Distribution.-British Isles (common), Faeröes, Iceland, Norway, Sweden, W. Baltic, Denmark, N. and W. France, Mediterranean, Adriatic, Moroceo, Canaries, Greenland, Atlantic coast of N. America. (Mass., Florida, Bermuda, W. Indies), Pacific (California).

\section{L. (Dermatolithon) hapalidioides Fosl.}

Dredged in Clew Bay on several occasions, and probably not uncommon, though often overlooked. The sub-littoral form is smooth, and very different in appearance from the variety confinis.

Var. confinis Foslie.-On Patella shells near low-water mark, not uncommon.

"La structure est la même dans le type et la variété, et c'est pourquoi Foslie $(1909$, p. 128) a réuni les deux espèces $L$. (D.) hapalidioides et $D$. confinis. Comme il le fait remarquer, le $L$. confinis correspondrait à la forme squamulosa du L. Lenormandi; on peut supposer que la var. type vit à une certaine profondeur sur les coquilles et au contraire que la var. confinis vit dans la limite des marées. La différence d'aspect résulterait d'une différence dans les conditions de vie." (M. Lemoine.)

Distribution.-British Isles, Faeröes, S. Norway, N. and W. France, N. Spain, Algeria, S. France (last three localities var. confinis only).

\section{I. incrustans Philippi.}

L. incrustans is the common incrusting alga of pools and rocks on exposed shores; and, with the exception of Cithothamnium Lenormandi, which forms a belt above it, it is the only species normally oceuring in the littoral region (see p. 41). In the shallow waters of Clew Bay, a very smooth form in addition to the ordinary is frequently found.

Var. subdichotomum Heydr.-To this curious variety must the $L$. dentatum of the west of Ireland be referred. 'The record is due to Foslie, who dredged specimens in Roundstone Bay in 1899. He first regarded them as forms of $L$. fasciculatum, but later referred them to $L$. dentatum. The latter is a native of the Adriatic; but though recorded from Naples and Tangier, its 
position in Ireland was very isolated, as it is entirely absent from the French coasts.

Specimens dredged by me in Clew Bay agreed well with Foslie's material in the Dublin Museum, and Dr. Lemoine, to whom a fragment was sent, at first passed it as that species. She, however, subsequently wrote that it bore a striking resemblance to certain curious forms of $L$. incrustans, which had been described from Guéthary (Basses Pyrénées) by Heydrich, and further examination showed that the structure agreed with $L$. incrustans rather than with $L_{0}$ dentatum. As it was advisable to have the point finally settled, further material was sent, including a specimen gathered by Foslie at Roundstone. Madame Lemoine kindly examined the samples anatomically, and reported as follows:-

"Je crois que tous ces échantillons représentent des formes de $L$. incrustans, mais ce sont des formes anormales et curieuses. Ce sont des échantillons âgés qui se sont séparés de leur substratum, et qui ont pris ce développement bizarre. Je me suis rendu compte aussi que l'algue était âgée, parce que, dans certains échantillons, en particulier dans celui de Clew Bay, le tissu se désagrège après décalcification, et il est impossible d'obtenir des coupes dans la partie centrale.

"Je ne suis pas arrivée à observer l'hypothalle, il aurait fallu abîmer les échantillons; les lamelles libres ne sont constituées que par le périthalle. J'ai étudié les deux échantillons de Roundstone dans lesquels les dimensions des cellules sont comparables à celles des cellules de $L_{\text {。 }}$ incrustans.

"Ises échantillons de Roundstone appartiennent à une forme décrite par Heydrich f. subdichotoma ['99, p. 225]. Ils seraient plus jeunes que celui de Clew Bay, qui, usé et roulé par les vagues, est tout à fait caractéristique de la f. subdichotoma."

A comparison of Heydrich's figures in the paper referred to (Berichte d.d. Lot. Ges. xvii, p. 221) shows that the Irish specimens agree in form with the Mediterranean. The plant is rare, but one or more isnolls were collected on each occasion that the Clew Bay or Roundstone "coral-banks" were dredged.

Distribution. - L. incrustans:-British Isles (abundant), Faeröes, N. and W. France, N. Spain, S. France, Italy, Dalmatia, Algeria, Morocco (Tangier and Atlantic Coast), Canaries, S. Africa, Sandwich Islands.

Var. subdichotomum.-Ireland (Clew Bay, Roundstone Bay), France (Guéthary, Banyuls).

\section{L. lichenoides Philippi.}

Lemoine (' 11, p. 128 , states that the anatomical structure of this species is clearly that of Lithophyllum, and she therefore restores it to that genus. 


\section{$15148 \quad$ Proceedings of the Royal Irish Academy.}

In England it is only known from the south coast; but it has been found in all the provinces of Ireland except Ulster, and is very common in the Clare Island district. It is usually attached to Coralline officinalis, and occurs in pools and in the low-littoral region.

Var. agariciformis Foslie.-Batters, following Foslie, regards $M$. agariciformis Harv. as a variety of this species; and Madame Lemoine, to whom I sent for anatomical examination a fragment of a Roundstone specimen (probably collected by McCalla), writes that there is no doubt whatever that Foslie was correct. The variety is evidently exceedingly rare, as no trace of such a form was found by me on any of the Lithothamnium banks of Clew Bay or Roundstone.

Distribution.-A southern species. S. and W. Ireland, S. England, N. and W. France, N. Spain, Mediterranean, Morocco.

Var, agariciformis. Roundstone Bay.

\section{L. fasciculatum Fosl.}

This species is known only from the west of Ireland, and is thus one of the most interesting algae of the Irish flora. It is known locally as "Wild Coral," and is plentiful in Clew Bay, occurring in patches mixed with Lithothamium calcureum. It is also common at Roundstone (see p. 70).

Foslie distinguished several forms of the present species ('09). The plant was accidentally omitted (or rather unintentionally united with another species) in Batters' Catalogue, as explained by me last year (Journ. Bot, p. 115).

Distribution.-Clew Bay! Roundstone! Fahy Bay! Schull and Ballinacourty (teste Johnson).

\section{Lithothamnium calcareum Aresch.}

The dominant species of the fruticulose Lithothamnium association of Clew Bay and Roundstone (see p. 69). It occurs in great diversity of form, but it seems clear that varieties compressa McCalla, squamulosa Fosl., crussid Len., subvalida Fosl., and subsimplex Batters, as described and figured by Lemoine (" 10 ), are the most common in the district. Reference should be made to that paper for details as to biology and ecology. Mamnin Bay, where $L$. calcaseum occurs abundantly, is worthy of further investigation, and should be compared with Roscoff and Concarnean, which have been investigated by French botanists.

Distribution.-British Isles, N. and W. France, Norway, Denmark, Portngal, Morocco, Algeria, Mediterranean (Naples, Adriatic). 


\section{Lithothamnium norvegicum Kjellm.}

$L$. norregicum is an addition to the published list of our flora. It has been, howerer, sent out recently by Holmes in his "Algae Britannicae Rariores" (No. 264); he obtained specimens from Arran (Scotland). The species resembles in form a small, much-branched specimen of L. calcareum ; but the branches are more slender and the whole plant more compact. The structure also is distinct (see Lemoine, '11, p. 108). It has doubtless been mistaken for $L$. calcareum in the past, and is probably not uncommon on our shores. In Clew Bay it occurred sparsely scattered amongst other species.

Distribution.-Clew Bay, Roundstone, W. Scotland (Arran); Norway, Denmark, America (N. Atlantic coast).

\section{L. laevigatum Fosl.}

(Phymatolithon laevigatum Fosl., Batt. Cat., p. 98).

A sub-littoral species, but found occasionally in caves. It was dredged off The Bills in about 15 fathoms, and was found on limpets in a cave on Clare Island.

Distribution.-England (Berwick), Ireland (Gola Island, Larne), Faeröes, S. Norway, Denmark, Atlantic coast of N. America (Rhode Island, Maine, Newfoundland).

\section{L. polymorphum Aresch.}

(Phymatolithon polymorphum Fosl., Batt. Cat., p. 98).

Common on exposed coasts in our area, and forming a band below L. incrustans, as explained on p. 41. For taxonomy see Lemoine ('11), p. 63.

Distribution, -British Isles (common), Norway, Sweden, Denmark, Faeröes, Iceland, Heligoland, N., W. and S. France, Tangier, Mediterranean, Adriatic.

\section{I. compactum Kjellm.}

(L. circumscriptum strömfelt ; Clathromorphum circumscriptum Fosl, Batt. Cat., p. 97).

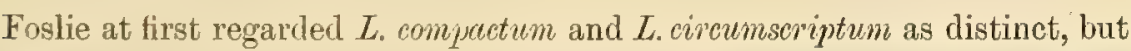
subsequently referred them to the same species. Kjellman's name antedates stromfelt's by three years, and must be adopted (see Lemoine, '11, p. 98). The plant was dredged twice, in 5 fathoms between the outer islands of Clew Bay, and in $T$ fathoms off Mulranny. It is listed by Johnson and Hensman ('99), but no locality is given, and it has not been found in England or Scotland.

Distribution.-Ireland (Mayo), Faeröes, Iceland, Norway, Spitzbergen, Nova Zembla, Greenland, Atlantic coast of N. America (Maine, New foundland, Nova Scotia), and Pacific Coast (Alaska). 


\section{Lenormandi Fosl.}

Common in our area, forming an irregular band on damip and shady

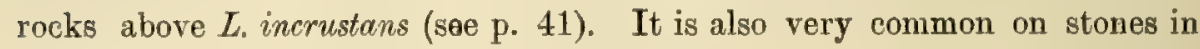
pools.

Var. sublaevis Foslie.-A sub-littoral form. Not uncommon in Clew Bay in 3-5 fathoms, on shells, especially Pecten.

Var. squamulosa Foslie.-Frequent on the sides of dark caves.

Distribution.-British Isles (common), Iceland, Faeröes, Norway, Sweden, Baltic Sea, Denmark, Heligoland, N., W., S. France, Mediterranean, Adriatic, Morocco, Canary Islands, N. America (Atlantic Coast).

\section{Sonderi Hauck.}

Beautiful specimens belonging to form sublaevigata Foslie were dredged from the "Helga" in Killary Bay. They formed a complete crust on the shells of mussels which occurred abundantly in muddy places. Superficially $L$. Sonderi strongly resembles $L$. Lenormandi; but the structure is quite distinct, the filaments in the former separating easily from each other, whilst in the latter the tissue is very compact (Foslie, '05, p. 24, Lemoine, '11, pp. 84 and 97). L. Sonderi has not been recorded from England, but specimens have been dredged by me at Plymouth in 1905 (teste Foslie).

Distribution.-British Isles, Norway, Sweden, Denmark, Heligoland, France.

\section{Epilithon membranaceum Heydr.}

(L. membranaceum Fosl, and L. corticiforme Fosl., Batt. in Cat., p. 97).

It is satisfactory to find that authorities agree in regarding the two species above cited as synonymous-a view held by several British algologists, though Batters in 1902 kept them distinct. Dr. Lemoine did not deal with the plant in her treatise on the Melobesieae ('11), but, in response to a special inquiry, she wrote the following note:-“J'ai étudié avec soin dans les Herbiers les $E$. corticiforme and $E$. membranaceum, je crois, comme d'ailleurs c'était l'opinion de Foslie $(1909$, p. 75), qu'ils doivent être réunis. Il est probable qu'on a désigné sous le nom de corticiforme les thalles portant des conceptacles à sporanges, et sous le nom de membranaceum ceux portant les conceptacles à crystocarpes. L'aspect des deux sortes de conceptacles est très différent; les conceptacles à sporanges mûrs forment des sortes de petits cratères qui laissent voir en leur centre le substratum; ces cratères, très nets sur l'échantillon de Clew Bay fixé sur Rhodymenia, sont souvent confluents et leur contour est ovale. Au contraire les conceptacles à cystocarpes sont d'abord hemisphériques; plus tard le toit tombe et il peut rester un petit trou 
à sa place, mais le trou est circulaire. Si on conservait l'indépendance des deux espèces, il faudrait admettre que dans chacune on ne connait qu'une seule sorte de conceptacles. Dans l'Herbier Bornet ces deux espèces sont séparées; j’ai cherché en vain des conceptacles à cystocarpes pour le $\boldsymbol{E}$. corticiforme. D'ailleurs d'après les descriptions de Rosanoff et de de Toni il est impossible de les distinguer. Hauck les a réunis."

It is clear that the present species cannot be retained in Lithothamnium ; and Dr. Lemoine believes that Heydrich, who first clearly pointed out its peculiarities, was justified in forming a special genus for its reception, and that it is advisable to adopt his name. The nomenclature is, however, somewhat complicated by the question of the validity of Kützing's genus Hapalidium. $E$. membranaceum is common in the Survey area, being found most often on Rhodymenia palmata and Furcellaria fastigiota. In autumn it is not infrequent on Cladophora rupestris in shallow pools near high-water line, to which it gives a very curious appearance. It is also found occasionally on other algae and on shells (Trochus).

Distribution.-British Isles (frequent), Norway, Sweden, N. and W. France, N. Spain, Mediterranean, Crimea, Morocco (Atlantic coast), Ceylon, California.

\section{Corallina squamata Ellis.}

This species is probably much more common in the warmer parts of the British Isles than is generally supposed. On the exposed coasts of Clare Island it is, as explained on p. 40, probably more abundant than $C$. officinalis. In the south of England also, I have noted it very frequently in similar localities.

\section{ECONOMIC SPECIES.}

$$
K e l p \text {. }
$$

Kelp-burning forms an important feature in the yearly routine of the islanders, as it does also on the exposed coasts of the mainland. During the last weeks of June and in the beginning of July dense clouds of heavy oily smoke may be seen along the coast-line, and the preparation for this general burning provides employment for many months. In a leaflet issued by the Congested Districts Board ${ }^{1}$ practical advice is given, including notes as to the relative value of the different seaweeds, and instructions as to the best methods of burning. Each species is figured, and also certain weeds which should be avoided.

1. "The Kelp Industry. Hints for Kelp-burners with regard to Seaweed." Congested Districts Board Leatlet. 1898 , 
The "rods" (stipes) of the various Laminariae employed are collected as they are cast ashore in autumn, winter, and spring, and placer on the stone walls till burning time. In February and March the weed is also cut by hand during the lowest tides. From April 1st until June the "tops" or "leaves" (laminae) are collected in addition to the rods; and these are mixed with the latter when burning. It is during April and May that L. Cloustoni sheds its fronds, hence the term "May Weed." The name "Red Wrack" is given on account of its red-brown colour after exposure to weather.

Of the weeds employed, the bulk of the rods consist of $L$. Cloustoni,

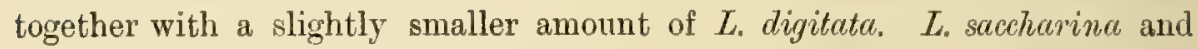
Sacchorhiza bulbosa are also used and are equally valuable; but they are not washed ashore in anything like the same quantity. A storm or ground swell provides the islanders with several days' work, the "rods" being picked out for kelp, and the tops used (except in April and May, when part is set aside for burning) on the fields as manure. The foliage of $L$. saccharina bleaches at once with rain, and is then of no value for kelp; $L$. digitata bleaches less readily; and $L$. Cloustoni, as noted above, turns reddish-brown. Alaria esculenta and Halidrys siliquosa are recommended in the Leaflet, and are used in small quantities with the "tops." Ascophyllum and Fucus spp. yield but a very small amount of iodine, and are usually rejected. One of the most important papers on the commercial value of algae is that by Stanford ('84), which, though somewhat out of date, has not been superseded.

\section{Manure.}

Seaweed is extensively employed as manure all round the coast. In many spots the drift-weed washed ashore is sufficient for requirements; but in others the weed is cut by hand from the rocks, whilst in a few localities it is actually cultivated.

A good dressing of seaweed is always applied to potato beds previous to planting; in some cases so soon before that the sets are practically placed over a layer of fresh weed. It is usually put on stubble after cutting oats, and applied again to the land in spring. A dressing is also spread on meadow land; and in May the reddish fronds of the "May Weed " (= L. Cloustoni), and the streaks of white due to patches of bleached $L$. digitata and $L$. succharina, give striking colour-effects on the green fields.

The species employed vary according to the nature of the shore. On exposed rocky coasts Laminaria is washed up; and where obtainable in plenty as in Clare Island, other weeds are despised. Laminaria is industriously collected during winter and spring, and carted or carried by panniered ponies 
to the fields; on the mainland it is at times carted seven or eight miles inland. In other localities, such as Old Head and Bartraw, the farmers are content with drift-weed of a miscellaneous description. The drift is more valuable at some seasons than others. At times it is composed almost entirely of semidecayed red weeds cast up from the shallow water, and at others there is a certain amount of Laminaria, and occasionally Fucus.

Black Wrack (Fucus vesiculosus and Ascophyllum nodosum) is systematically collected during February and March, where Laminaria is searce. In the rocky parts of Clew Bay, and in many localities on the open coast, it grows freely on the rocks, though for a really large amount a flat shore is essential. This is supplied in abundance in the inner part of the bay, and in Achill Sound. Where rocks are present Fucus grows naturally, but where, as is usually the case, the shore is composed of sand, the farmers set to work to obtain a growth of Wrack by artificial means. Stones about a foot square are disposed in rows a yard apart, with paths left between for carting. Sporelings speedily appear on the stones, and during the course of a year develop into good-sized plants. The following season the Wrack is cut. This operation, which takes place in February and March, was observed by the Survey party of Easter, 1910. The reed on cutting is built up in stachs about six feet high, and after being tightened up with ropes is towed ashore on the flood-tide, and bleached at high-water level. Here it is unpacked and carted to the fields.

The botanical features of the Fucus-farms are dealt with on p. 53 . Owing to the symmetrical arrangement of the stones, the artificial plots are at once distinguishable from natural vegetation; but when the weed is in its second season and the plants inclined to overlap, the distinction might not strike the eye of a casual observer. Plate $V$, fig. 2, gives a view of the plots at Darby's Point; similar farms oceur in other parts of Achill Sound, and in Clew Bay they were noted at Murrisk.

The "coral-sand" described on p. 71 should be referred to here, as it is rised for manuring in Connemara. Johnson and Hensman ('99) give the analysis of a Bantry Bay sample, which shows that the sand consists of about 80 per cent. of carbonate of lime. 'lo this fact its efficacy as a fertilizer is attributed, and it is doubtless specially useful on the peaty shores of W. Ireland.

\section{Recent Literature.}

The Composition of Seaweed and its use as Manure. Journ. Bd. Agr. London, xvii, pp. 458-467 (September, 1910), p. 832 (January, 1911). Also abridged as Leaflet No. 254.

R.I,A. PROC, VOL, XXXI, 
Seaweed as Manure. Journ. Dept. Agr. and Tech. Inst. for Ireland, xii, pp. 84-87. (October, 1911.) Also as Leaflet No. 99.

Sewage Commission Reports. The manurial value of Ulva and the significance of its nitrogen-content are dealt with in the reports referred to on p. 108.

\section{Food-stuffs.}

Three algae are collected for edible purposes in the Survey-area; but they are taken as relishes rather than as articles of food. During times of scarcity, however, Dillisk and Sloke form a useful addition to the daily menu. In Clare Island the only alga which is regularly sold as a coinmercial article is Carrageen Moss.

Dillisk and Crannogh.-The Irish Dillisk or Scotch Dulse is the common Rhodymenia palmata, the fronds of which are chewed in a fresh state or after having been dried. Crannogh is the small form of the same species found as a dense short growth on rocks in exposed places (p. 32). The flavour is peculiar somewhat pungent, but not unpleasant. On Clare Island,Dillisk and Crannogh are esteemed more highly than Sloke, probably owing to their being less abundant. On Achill Island, on the other hand, Crannogh is said to be the most plentiful.

Sloke (Slouk, Sloukuen, or Sloukaum). - Sloke, the Laver of the English, is the short crumpled form of Porphyra umbilicalis, which grows abundantly on exposed rocks (p. 28). The large flat form is not usually employed, except at Mulranny, where it is said to be collected and sold to tourists. Sloke is gathered in spring, and either stewed at once, or boiled into a jelly, and set aside for future use. When required, this jelly or "laver bread" is re-cooked, and then fried with butter. Used on Clare Island and on many parts of the mainland.

Carrageen or Iceland Moss. - The true Carrageen is Chondrus crispus, but certain forms of the allied plant Gigartina mamillos are often included with it. Both are common on rocky shores; but they do not occur in such masses as either Dillisk or Sloke. It is still exported from several districts in Ireland, and is sold in at least two localities in our area. On Clare Island it is collected and sold to Dublin, and from thence to Liverpool, where it is said to be chiefly used for fattening calves. On the small island of Inishbiggle, four miles north of Achill Bridge, Mr. J. Tydd Frere has successfully encouraged the collecting of the weed by the peasants. The "Moss" is mainly bought by a Dublin agent, but smaller quantities are also sold to private persons in England and the colonies. As observed at Inishbiggle the weed is left to bleach on the grass, after which it is dried and stowed away in sacks. For culinary purposes it is boiled down to a jelly, and then 
added to milk, or used as a substitute for isinglass. Carrageen is still employed in some quarters as an antidote for lung-troubles.

The following notes, though referring to a county outside our area, are of interest. They were supplied by Mr. Thomas Crehan, of Miltown Malbay, Co. Clare (sometime the home of W. H. Harvey), who, as agent for a firm of Euglish ship-merchants, has dealt for many years in the sale of seaweeds :-

Crannogh.-Collected at Miltown Malbay all the year round, and sold to Blackburn at 1 s. per stone.

Cerrogeen.-Sold to London, Scotland, Germany, Russia, and America, fetching $£ 810$ s. a ton, or $1 \$$ a $1 \mathrm{~b}$. in America. The narrow form is used for edible purposes, and the wide form chiefly for dressing linen, manilla ropes, and other articles.

Sloukaen.-Sold to England for making "laver bread" at $2 s$. a stone.

\section{The Flora of The Bulls.}

Though not so interesting as the terrestrial flora, the marine vegetation of these rocky islets is worthy of a special note. Nine miles from the mainland, and surrounded on all sides by deep water, they are subjected to the severest exposure.

Two algal communities were conspicuous:-the Prasiola association, covering the bird-cliffs and ascending on the shady side to 50 feet or more above sea-level, and the Laminaria band, which encircles the islets at lowwater mark. The littoral region is for the most part compressed into its minimum horizontal range, being in many places nearly vertical. Several of the more accessible spots were examined. Alaria is more abundant than $L$. digitate; and Gigartina forms on almost vertical surfaces a band above. On the eastern side patches of the Porphyra and of the Callithamnion urbuscula communities were noted on the less precipitous rocks; but except for these, other associations appeared to be absent. The full list of species noted is appended :-

Plectonema tenebrans (in Balanus).

Prasiola stipitata.

$P$. crispa var. marina.

Enteromorpha compressa.

E. micrococer.

Chaetomorpha aerea.

Rhizoclonium riparium.

Cladophora prolifera.

C. rupestris.

Scytosiphon lomentarius.
Alaria esculenta.

Laminaria digitata.

Porphyra umbilicalis.

Gigartina mamillosa.

Chylocladia clavellosa.

Polysiphonia macrocarpa.

Callithamnion arbuscula.

Ceramium acanthonotum.

C. atlanticum.

Lithophyllum incrustans. 


\section{IV.-THE CHARACTER OF THE FLORA.}

\section{Notes on the Novelties and Additions.}

As already mentioned, the systematic list contains the names of 437 species and 36 varieties. The revised census, as recorded by Mr. Adams' private annotated copy, gives the total number of species for Ireland as 464 ; so that making allowances for 12-15 species which are now regarded as synonyms $\mathrm{or}^{\circ}$ varieties, the Survey list is within fifteen species of that for the whole of Ireland. ${ }^{1}$ As a local list, it must therefore be regarded as very complete, though amongst microscopic and sub-littoral species additions doubtless could be made by careful and continuous searching.

The list of additions to Ireland, which consists of ninety-two species and eleven varieties, is given below. It will be noted that it includes eighteen species and four varieties (marked $\dagger$ ) new to the British Isles, of which the following five are new to science :-Calothric endophyticn, Codium mucronatum var. atlanticum, var. nov., Ascocyches Saccharinae, Fucus vesiculosus var. muscoides var, nov., Ptilothamnion lucifugum.

Aphanocapsa pallida.

Dermocarpa violacea.

Pleurocapsa amethystina.

Spirulima subsalsa var:* oceania.

Oscillaria margaritifera.

O. Corallinae.

O. laete-virens.

O. sancta.

Phormidium fragile.

$+P$. persicinum.

$+P$. subuliferum.

Lyngbya Meneghiniana.

tL. confervoides.

L. semiplena.

L. lutea.

+Symploca dubia.

Plectonema Nostocorum.
P. Battersii.

P. norvegicum.

Microcoleus chthonoplastes.

M. tenerrimus.

Calothrix consociata.

$\dagger$. endophytica sp. nov:

C. parasitica.

C. aeruginea.

Brachytrichia Balani.

Microchaete grisea.

Codiolum gregarium.

C. Petrocelidis.

Protoderma marinum.

Ulvella fucicola.

Monostroma orbiculatun.

Capsosiphon aureolus.

Enteromorpha prolifera.

'Some further species would have had to be added if Batters' Catalogue had been exactly followed; but in the systematic section several reductions have been made.

- In this list signifies that the variety only is new to Ireland. 
E. minima.

Ulotbrix consociata.

$\dagger$ U. pseudoflacca.

$\dagger \mathrm{U}$. subflaccida.

Phoeophila dendroides.

+Rhizoclonium Kerneri $f$. endozoica.

Cladophora Neesiorum.

Ostreobium Queketti.

Vaucheria coronata.

+Codium mucronatum var. atlanticum var. nor.

+Stictyosiphon adriaticus.

Phyllitis zosterifolia.

Streblonema sphaericum.

Ectocarpus clandestinus.

E. microspongium.

E. Battersii.

E. Holmesii.

E. Mitchellae.

Myriotrichia densa.

M. repens.

+Dichosporangium Chordariae.

Myriactis stellata.

M. Haydeni.

Leptonèma fasciculatum.

Sphacelaria plumula.

Myrionema Corunnae.

I. papillosum.

M. aecidioides.

M. saxicola.

M. reptans.

Hecatonema reptans.

H. speciosum.

Microspongium globosum.

Chilionema ocellatum.

Ascocyclus foecundus.

+A. Saccharinae sp. nov.

Lithoderma fatiscens?
+Petroderma maculans.

Mesogloia lanosa.

+ Acrothrix gracilis.

Fucus vesic. $v a r$. tmuscoides val: nov.

Erythrotrichia investiens.

E. Welwitschii.

Porphyra coccinea.

Colaconema Bonnemaisonii.

Chantr. virgat. rar. "luxurians. var. ttetrica.

$+\mathrm{C}$. Thuretii.

Harveyella mirabilis.

Gelidium aculeatum.

Callymenia Larterae.

Gracilaria conferv. var. *procerrima.

Nitophyllum Bonnemaisoni var. *crassinervum.

Rhodymenia palm. vur" *sarníensis.

Bonnemaisonia hamifera.

Dasya corymbifera.

Spermothamnion Turneri var. †subverticillatum.

†Ptilothamnion lucifugum $s p$. nov.

Bornetia secundiflora.

Seirospora hormocarpa.

†Ceramium Boergesenii.

+ C. atlanticum.

Petrocelis Hennedyi.

Porphyrodiscus simulans.

Rhododermis polystromatica.

Lithophyllum crustans var. †sub. dichotomum.

Lithothamnium norvegicum.

L. Lenormandi var. *sublaevis.

L. $\quad " \quad v a r$. ${ }^{*}$ squamulosa. 
(11) Additions to the British Isles. - With regard to these, the following nine are inconspicuous species which are probably to be found in England and Scotland if carefully searched for:-

Phormidium persicinum.

P. subuliferum.

Lynghya confervoides.

Symploca dubia.

Ulothrix subflaccida.
Ulothrix pseudoflacca.

Dichosporangium Chordariae.

Petroderma maculans.

Chantransia Thuretii.

Of the remainder:-

Calothrix endophytica sp. nov., is conspicuous on salt-marshes, and should be searched for in Britain.

Rhizoclonium Kerneri forna eulozoick forms green masses in the sponge Halichondria, and probably occurs in England.

Codium mucronatum var. atlanticum. - This species is new to Europe. It loes not occur in the south of England, but is recorded in the present report frum south-west Scotland, Isle of Man, and the Orkney Islands, in addition to the north, west, and south-west of Ireland.

Stictyosiphon adriaticus. - Rare, and only obtained by dredging. It should be found in quiet bays on the south coast of England.

Acrothrix gracilis. - Probably very rare. Perhaps overlooked as Mesogloia Griffithsiana.

Fucus vesiculosus var. muscoides, var. nov,-This variety has never been noted in England. It is probably confined to peaty shores.

Spermothamnion Turneri var. subverticillatum., - I have not observed var. subcerticillatum in England; but it doubtless occurs in quiet bays on the south coast, since it is known from France. In Clew Bay it is frequent throughout spring and summer.

Ptilothamnion lucifuyum.-Caves are frequently explored by algologists ; but this beautiful microscopic species has hitherto escaped detection. It is allied to Ptilothamnion micropterum, which is only known from the Canary Islands and Guéthary (Basses Pyrénées). Probably a southern species.

Ceramium Boergesenii.-Doubtless common in England, but passed over as $C$. decurrens.

C. atlanticum.-This pretty and fairly well-marked species probably occurs in Fngland and Scotland. A few specimens only were found on Clare Island.

Lithophyllum incrustans, var. subdichotomum.-Identified correctly for the first time by Dr. Lemoine, in the present report. Only known in the 
British Isles from Clew Bay and Roundstone. It is doubtless dependent upon a very special type of ground.

(b) Additions to Ireland.-On examining the additions to the Irish flora we find that a large proportion are minute or critical species which require careful search and microscopic examination. In earlier days the west coast list was well up to date, but in recent years, when algology in our islands has been at a low ebb, the Irish seaweeds have been neglected, and the numerous microscopic species discovered in other countries have not been searched for in Ireland. Johnson added many to the Phoeophyceae some twelve to fifteen years ago; and Adams more recently has recorded additions to various groups. Batters' Lambay list ('07) furnished twenty species new to the Irish flora.

In the present account the Myrionemaceae are specially well represented, owing doubtless to a knowledge of their appearance in the field, gained during four to five years monographic work on the group. With the exception of the exceedingly rare Ascocyclus hispanicus, all the British species were found during the Survey. Several require particularly close observation, and have only been recorded once or twice previously for our islands.

Amongst the more interesting plants new to Ireland, we may mention, in addition to those already alluded to:-

Cladophora prolifera.-A very distinct species collected on The Bills. In the British Isles, known previously from Weymouth only.

Monostroma orbiculatum. - A salt-marsh species found in beautiful condition on Annagh Island.

Capsosiphon aureolus.-Found at the mouths of fresh-water streams. Hitherto known only from Scotland, but probably overlooked.

Vaucheria coronata.-Forming zones and broad associations, of a deep green velvet appearance. Exceedingly abundant in Clew Bay.

Ectocarpus clandestinus.-Probably rather rare. Fine material gathered on Clare Island in October, 1910.

E. Holmesii._-Under the bridge at Achill Sound and in caves. Found on several occasions with both kinds of fruit and in beautiful condition.

E. microspongium.-Very inconspicuons, forming minute cushions on crusts of Ralfsia.

Mesogloia lanosa.-Dredged in Clew Bay in 1909. A most distinct species, but rare and little known.

Porphyra coccinea.-Probably short-lived. Known from four localities only in the British Isles.

Gelidium aculeatum.-Formerly regarded as a form of G. corneum. 
Bonnemaisonia hamifera.-Usually considered to be an alien species from Japan (see p. 136).

Drsyc corymbifere.-A sub-littoral species. Known in England from Dorset and the Channel Islands only.

Bornetia secundiflora.-One of the most interesting additions. Headquarters in the Mediterranean (see p. 141).

Seirospora hormocarpa.-Rare, but easily mistaken for other species; hence perhaps overlooked.

Lithothamnium nonegicum.-Probably not uncommon in Ireland, but regarded in the past as a variety of $L$. calcareum.

\section{The Character of the Flora.}

The flora of Clare Island and Clew Bay resembles that of the southwest of England, and is thus of a distinctly southern type. A number of species occur which have not been found in Scotland, the east and southeast of England, or Wales, though it must be remembered that much of the shore of our east coast is unsuitable for a littoral flora, and that Wales has been very little explored. Many species in the list are known only from the south and west coasts of Ireland, but here again further exploration would probably show a wider range.

\section{Notes as to Absentees.}

Pefore attempting to analyse the flora, a few remarks may be made on the larger algae which were to be expected, but which were not met with during the Survey. Of species known to occur in several parts of Ireland, the following may have been overlooked, since they are rare or only occur sparsely:-

Asperococcus compressus.

Arthrocladia villosa.

Achinetospora pusilla.

Porphyra miniata.
Helminthocladia purpurea.

Gigartina acicularis.

Daysa ocellata.

Pleonosporium Borreri.

Bryopsis hypnoiles is a more noticeable absentee, as when present it is usually plentiful. The same may be said of Nitophyllum Gmelini and N. Hilliae, both of which are known from counties Cork, Kerry, and Clare, and also from Belfast Lough. Clew Bay would appear very suitable for their growth, and as their season is a fairly long one, we must conclude that if present they are very rare. In Plymouth Sound they are found in abundance. Naccuria Wigyii also was not seen in any of the dredgings. 
At the same time it should be remembered that several large and couspicuum species were found only once.

Of southern algae, Callithamnion tetricum may be safely stated to be absent. This coarse, shaggy species is known from Munster and Leinster, and from the southern counties of England. ${ }^{1}$ Its habitat-steep sides of rocks-was carefully searched on each visit, but without success. There appears to be no record north of Bantry. Halopithys pinastroides is certainly absent, ${ }^{2}$ and probably Pterosiphonia complanuta. With regard to northern species, Odonthalia dentatu and Rhodomela lycopodioides ${ }^{3}$ are wanting. They are found in Ulster, but do not extend far down the west coast. Monostroma fuscum was searched for in vain, probably for the same reason; it is abundant in Belfast Lough, and many parts of Clew Bay offer similar ground.

Of very rare species, Stenogramme interrupto, a singular plant found in many parts of the world, and which oceurs in the south of England, and at Cork and Portaferry (Co. Down), was not found in any of the Clew Bay drelgings. By some it is regarded as an alien on our shores. A special search was made amongst the Fuci, but nothing approaching the curious Fucus "nreps Harr. and Tard, of Kilkee was seen. Spyridia filamentosa should also be mentioned. This is locally abundant on the south coast of England, and in Wales reaches as far north as Holyhead; yet in Ireland it is unknown. A single specimen was found amongst dried material brought home from Achill in July, 1909: but as the plant was never observed during the Survey, there ran be little doulst that it was an English specimen which was taken over to Achill with the drying paper.

\section{Analysis of the Flora.}

An attempt was made, but without much success, to classify the Clare Island flora after the method adopted by Börgesen and Jónsson ('05). These anthors recognize five groups, arctic, sub-arctic, boreal-arctic, cold-boreal, warm-boreal, and have with much care classified the arctic and northernmost Atlantic floras according to this scheme. But the Clare Island investigations will prohably tend to modify the riews held in some cases; and in assigning plants to groups such as these, the personal factor cannot be eliminated. A great many Irish species do not fall into any of the five divisions, owing to the fact that the flora contains elements which belong to more southern regions. These species it is hy no means easy to classify, chiefly on account of the

\footnotetext{
1 The Cromer record in Batters ('02), is probably incorrect.

2 The Irish records of this plant require confirmation.

'Adams gives a Munster record for $R$. lycopodioides; but the case should be re-investigated. Ri.A. PROC, VOL. XXXXI. 
scarcity of records. The fact that the Survey has added about 250 species to Connaught, and over 100 species and varieties to Ireland, shows how little we really know of the distribution of algae. The south-east of Ireland needs special attention; also south-west Wales, north Cornwall, and the Scilly Isles. Börgesen has pointed out how badly the Shetland algae are in need of re-investigation ('05, p. 787 ; see also '03); and the same applies with equal force to north-west Scotland. For Donegal and the coast-line generally between Achill and Portrush there is hardly a record; and yet it is along this coast that the southern species disappear and the northern forms, such as Odonthalia dentuta, Porphyra miniatu, and Monostroma fuscum, begin to show. With regard to France and Spain, although we have good French handbooks, additions to the flora may still be made; and were it not for Sauvageau's two valuable lists (97), which are admittedly preliminary, we should have practically no reliable data for the north of Spain.

For the above reasons I have not attempted to classify the whole flora into definite phytogeographic groups. We may, however, recognize certain well-marked elements, and by means of these attempt to analyse it.

(a) Southern Element.-Of the species which have a markedly southern distribution, the following are among the most noticeable :-

Cladophora prolifera.

Codium adhaerens.

Mesogloia lanosa.

M. Griffithsiana.

Petrospongium Berkeleyi.

Cutleria multifida.

Bifurcaria tuberculata.

Cystoseira ericoides.

C. granulata.

Taonia atomaria.

Dictyopteris inembranacea.

Nemalion elminthoides.

Callymenia reniformis.

Bonnemaisonia hamifera.
Bostrychia scorpioides.

Chondria tenuissima.

Polysiphonia subulifera.

$P$. furcellata.

Dasya corymbosa.

Spondylothamnion multifidum.

Halurus equisetifolius.

Monospora pedicellata.

Bornetia secundiflora.

Callithamnion granulatum.

C. tripinnatum.

Compsothamnion thuyoides.

Schizymenia Dubyi.

Corallina squamata.

We may mention also eight species which were not found during the Survey, but are known to occur in S.W. Ireland:-

Asperococcus compressus.

Helminthocladia purpurea.

Gigartina acicularis.

Nitophyllum Hilliae.
Nitophyllum Gmelini.

Pterosiphonia complanata.

Dasya ocellata.

Callithamnion tetricum. 
Nearly all the above species are confined in England to the southern counties. Several have been found only in south Devon and sonth Cornwall; others reach as far as the Isle of Wight; whilst a small number extend through the Straits of Dover as far north as Norfolk. All are known to occur in Normandy or Brittany, and with few exceptions they have been recorded by Saurageau from the Bay of Biscay and north Spain. Though their headquarters are in a southerly direction, a few extend up the Irish Channel to Anglesea and the Isle of Man; and several have been noted in the Clyde area and in the Orkney Islands. The Clyde has been thoroughly worked (see Batters, '91); hence numerous outliers have been detected. The Orkney recorls are distinctly interesting, and tend to show that some of the southern forms in the west Irish flora extend northwards by way of the Hebrides. For this the Gulf Stream drift is doubtless responsible.

The plants listed above grow luxuriantly in Ireland, and are evidently at lome in their surroundings. The much-indented coast supplies great variety of conditions; and the lack of intense insolation in summer permits the presence of a better littoral and shallow sub-littoral vegetation than in the south of England. Several of the species are only found sparingly, as in other parts of our islands; but others occur in great profusion-e.g., Petruspongium Berkeleyi, Dasyce arbuscula, Polysiphonia subulifera (local), and Corallina squamata; whilst Codium adhaerens, Cutleria multifida, Bifurcaria (at Roundstone), Cystoscirc fibrosa, Halurus, Monospora pedicellata are very frequent. The abundance of Dasyce arbuscula at low-water mark on Clare Island is very remarkable (see Phyc. Brit., tab. 274).

(b) Northem element.-With regard to northern forms we find that there occur in our area a large number of the species which Börgesen and Jónsson place in their sub-arctic and boreal-arctic groups. Many of these have, however, a very wide distribution, being abundant in all parts of the British Isles and extending to France and even Spain. Of the most noticeable boreal species (selecting from well-known plants only) we may pick out seven for notice. The first four are annuals, ${ }^{1}$ and occur chiefly in spring; the last two are found all the year round, and are important constituents of the flora.

Stictyosiphon tortilis.-Very common in Clew Bay during spring, also in Scotland. It occurs in Northumberland, Cheshire, and Carnarvon. Batters gives a Cornwall record; but if it occurs on the south English coast, it must be extremely rare.

Desnotrichum undulatum.-Common in Clew Bay. Not known from England, but recorded from several localities in Scotland. It is rather small,

I The distribution of many of the smaller and inconspicuous species is so imperfectly known that they are best omitted. 
so may have been overlooked; but most of the southern records of this plant prove to be errors for Punctaria tenuissina. It is also known from the Faeröes, Kiel, and W. Sweden.

Phyllophore Brodiaei. - See note on 1). 134. The plant is known from Nova Zemblya, Spitzbergen, E. Greenland, Icelaud, Norway, Sweden, Baltic, Scotland, N. England, and N. Ireland, and may therefore claim to be a distinctly boreal species. In Clew Bay it is scarce, but several colonies were noted at Mulranny.

Lithothamnium norvegicum. - Scattered amongst $L$. calcarcum in Clew Bay and at Roundstone. Known from Scotland, Norway, Denmark, and the N. Atlantic coast of $\mathrm{N}$. America. It has not heen observed in the Lithothamnium banks of the English or French coasts.

Lithothamnium compactum.-Madame Lemoine remarks that this is a distinctly boreal species. It is known from Nova Zemblya, Spitzbergen, Iceland, Norway, Greenland, and the N. Pacific coast of N. America.

Callithamiion arbuscula.-The presence of this boreal species on the Irish west coast gives the appearance of a distinct overlapping in the flora. In the colder waters of the North Sea it is not known south of Yorkshire ; ${ }^{3}$ and on the west coast of Great Britain it descends to Ayrshire and the Isle of Man. On Clare Island it is abundant, and forms a conspicuous belt, just as it does in Scotland, Norway, and the Faeröes. It is recorled by Adams for Munster and Leinster, and probably extends right round the Irish coast.

Ptilota plumosı. - Another anomaly on the west coast. Listed by Börgesen as a sub-arctic species and general in Iceland, Nova Zemblya, and Spitzbergen, $P$. plumosa descends as far as Yorkshire on our east coast, and North Wales and the Isle of Man on the west. In Clare Island it is plentiful on the stipes of Laminuriu Cluustoni, and is washed ashore in company with such southern plants as Taonia and Callymeniu reniformis. Adams lists it from Munster and the south of Ireland; but as the older writers often confused the plant with Plumaria elegans, it would be advisable to confirm its presence in the southern provinces. In the London herbaria, there are no specimens south of Renvyle (Co. Galway).

(c) Other interesting species. - The most noteworthy alga in the list is undoubtedly Codium mucronatum var. atlanticum. This had either to be regarded as a new and endemic species, or to be linked with the Australasian C. mucronatum. The agreement in microscopic structure with the latter was found to be so close, that it was impossible to rlo otherwise than regard it as a form of that species. Its position on the west coasts of the British Isles is, however, remarkably isolated, as it is not known elsewhere in Europe, nor indeed

\footnotetext{
${ }^{1}$ Batters gives an Isle of Wight record; but this is almost certainly an errot for $C$. granulatum, a compact form of which is not uncommon in that locality.
} 
in the North Atlantic. It is almost impossible to believe that $C$. mucronatum can have been introduced, as at least one herbarium specimen shows that it has existed in S.W. Ireland for 100 years. At the same time, the preference of the plant for well-lighted pools, and the fact that it apparently disappears in autumn, might be taken as an indication that it is a native of a warmer region. That it was introduced from the British Isles to Australia and New Zealand is out of the question. For the present the plant must remain a remarkable case amongst algae of discontinuous distribution. Itis precise range in the British Isles should be ascertained. When this is known we will be in a better position to pronounce as to the status of the plant, and to discover if it is spreading on our shores. From S. Devon and S. Cornwall it is (or was, a few years since) certainly absent, but the same cannot be said of Wales, as that coast has not been carefully worked. It is abundant in the Isle of Man; but no records are known from the east and south of Ireland.

The best-known case of an alien alga in the British Isles is that of Colpomeniu sinuosn, which has been kept under observation in France and England (Sauvageau, '07, Cotton, '08, '11). It is a conspicuous plant, and was first observed both in France and England (Scilly Isles) in 1905. By 1909 it had spread as far as Hampshire, and it occurs now in great profusion in many parts of Coruwall, Devon, and Dorset. Colpomenia is specially adapted for floating; hence rapid colonization is comparatively easy. It affords an example of a Mediterranean species adapting itself to the conditions of a colder sea, and becoming naturalized at once. Codium mucronatum, on the other hand, does not readily float, and is probably much less hardy.

Bonnemaisonia hamifer a provides another problem. It is known in Europe from several places in the English Channel, and has always been regarded as of Japanese origin. By means of its hooked branches it clings tenaciously to floating weed, and is thus no doubt capable of being transported for a considerable distance. Its occurrence on Clare Island was most unexpected, and raises a doubt as to whether the plant after all is not indigenous to our islands (see p. 136). On the other hand, there is the noteworthy fact that it was not noted by McCalla nor by any other west-coast collector, and that until 1895 it was unknown in Europe. If an introduction, it can inardly have come direct to the west of Ireland; but as nothing is known as to its presence or absence in the southern provinces, it is useless speculating as to the method of transport or port of entry.

Questions such as those raised above make us feel our lack of knowledge, and emphasize the need of further study of our own flora. The vitality and floating power of detached seaweed are likewise in ueed of investigation. A 
mere list of species found floating, either of their own accord, or entangled with débris, would be of interest, and could be easily compiled by those who spend much time in dredging, tow-netting, etc. The algal growths on the bottoms of both large and small vessels present, moreover, an almost unworked field.

\section{COMPALISON WITH OTHER ATEAS.}

East Ireland.-A comparison of the Horistic features of the east and west of Ireland does not reveal so great a contrast as was expected. No special account of the east-coast flora has been published, nor have I personally examined any part of the shore, except the extreme north. Adams ('08, annotated copy) lists most of the Clare Island austral species for Leinster, and a considerable number for Ulster also. There are, however, ten well-known and conspicuous algae which have not yet been recorded for the east coast, but most of these would probably be found in Leinster if carefully searched for. S.E. Leinster is similar, as to its flora, to Munster; and Ulster has a surprising number of southern species, Belfast and Larne Loughs being at one time famous for Nitophylla and other seaweeds which occur chiefly in the southern counties. At the same time, it would be divisable to confirm such records as Bifucaria, Callithamnion tetricum, and Schizymenia Dubyi. The real difference between the east and west coast lies doubtless in the proportion of southern vegetation present; plants which are cornmon or frequent in Mayo and Galway being probably rare or very rare in Co. Dublin. The luxuriant growth displayed by such species as Lomentaria clacellose and Desya arbuscule, is also a characteristic feature of the west-coast vegetation.

England and Scotland.-With regard to England, as already shown, the Clare Island flora resembles that of Devon and Cornwall, but in England the boreal element (represented by Collithamion arbuscula, and Ptilota plumosa) is wanting, as are also several other northern species. Codium mucronatum is likewise entirely absent. Such plants as Acrothrix and Stictyosiphon adriaticus, known at present in the British Isles only from Ireland, will probably be found in England when our south-coast bays have been more thoroughly explored by dredging. On the other hand, a few well-known and conspicuous species, more or less frequent in Devon and Cornwall, have not been found in Ireland. The most noteworthy amongst these are Punctaria crispata, Gracilaria compressa, Grateloupia filicina, G. dichotoma, and Spyridia filamentosa, the lastnamed being locally abundant in Great Britain, and extending from Sussex to Anglesea. There are also other species, but these are of very rare occurrence. The east coast of England is comparatively poor; more than two-thirds of the speries listed on p. 162 are entirely absent; the remainder have been reported 
to occur more or less frequently as far north as Norfolk. When Yorkshire is reached, the four boreal species, Odonthalia, Rhodomela lycopodioides, Ptilotı plumosa, and Callith cmmion arbuscula, become noticeable and are abundant from this county northwards. The east of Scotland possesses a similar type of flora, and additional northern forms appear (e.g. Stictyosiphon, Euthora). The Orkney Islands, on the other hand, show a southern element, which is doubtless present also in the Hebrides. Details as to the flora of the Hebrides and the connexion with S.E. Scotland, N.W. and N.E. Treland would be of great interest.

Faeröes. - The British and Faeröese floras have already been elaborately compared by Börgesen ('05, pp. 784-788); and the Clare Island investigations do not materially modify his statements. Börgesen naturally was most concerned with the flora of Scotland and the Shetlands; and in conclusion he states that "the Faeröese algal flora must be regarded as a rather poor selection of the algae of Scotland and the adjacent islands, as almost all the Faeröese algae are found on the coasts of Scotland; whereas Scotland, on the other hand, has a very great number of species which are wanting at the Faeröes. The greatest resemblance is between the Faeröese flori and that of the Shetland Islands; the Faeröes have a few, perhaps no more than six, specially northerm species, which will probably not be found in the Shetland Islands." The six species referred to are Alaria Pylaii, Rhodophyllis dichotoma, Halosaccion ramentaceum, Ptilota pectinata, Rhodochorton penicilliforme, and Lithothamnium laeve. Of these the Rhodochorton has since been recorded as British (Batters, Journ. Bot., '06, p. 3); and a somewhat doubtful record of $L$. laeve exists for Ireland. The first four, however, could not easily be overlooked; and it is very unlikely that they extend as far south as the British Isles. With regard to Ireland, other species might be added to Börgesen's list, as several which he assumes may be found in the north of Scotland will hardly descend to Ulster; and Fucus influtus, Euthora cristatu, and Antithamnion floccosum, known on the east of Scotland or Shetland, have never been found in Ireland. The curious overlapping of north and south in the algal flora of the west of Ireland consists, as one would expect, in a continuous southern extension in the range of certain boreal species rather than in the presence of isolated patches.

France and Spain. - The flora of France and the Bay of Biscay is of special interest, and may be outlined here. The species found in Normandy and Brittany are practically the same as those of Devon and Cornwall, though doubtless in Brittany the southern element is present in greater quantity. South of the Loire the flora undergoes a change; and in the Biarritz and Guéthary neighbourhood it possesses a decidedly southern facies. Fucus and 
Ascophyllum are practically absent from Biarritz, and such plants as Spathoglossum Solierii and Liagora viscida are of frequent oceurrence. On the north coast of Spain these southern species cease to flourish; and a vegetation of the Brittany type re-appears. At Cape Ortegal the flora changes again; and, by the advent of such algae as Phyllaric purpurascens and Laminaria pallida, it receives a stamp which is characteristic of Cadiz and Morncco (see Sauvageau, '97). There appears to be no element in the Irish flora which is specially characteristic of the Spanish peninsula. Many species are common to both countries; but these for the most part extend right up the coast of France, and are also to be met with on both sides of the English Channel. The Biarritz neighbourhood is peculiar in possessing a flora of particularly austral type.

Neither is there any evidence of a S.W. France or Mediterranean element, such as is represented amongst flowering-plants by Dabeocia and Evicu mediterranca. The two Mediterranean algae for which the west of Ireland was specially noted were both wrongly named; and a third less familiar species, with the same geographical distribution, has had to be struck off the list. The record of Corium elongatum (a native of the South of France and North Africa) was an error for C. mucronatum; Lithophyllum dentatum (a species not known outside the Mediterranean) must be replaced by L. incrustans var. subdichotomum (teste Lemoine, p. 146); and Peyssonnelia rubra, though still a puzzle, was certainly an erroneous determination. The lastnamed has been recorded from many warm-temperate and tropical regions, often incorrectly. It was originally described from the Ionian Islands, and in the British Isles was supposed to occur at Roundstone and Plymouth. The species of the genus are singularly difficult to differentiate; lut whatever the Irish plant may lue, it is clear from an examination of the type specimens that it is not $P$. rubra. On the other hand, Bornetia secundiflora, which is abundant in the Mediterranean, and found sparingly in Brittany, Devon, and Cornwall, and more frequently in west France, may be added as a rare plant to the west-coast list. 'The majority of the sunthern species listed for Clare Island appear to have their headquarters in S.W. England, W. France, and N. Spain, rather than in southern Europe.

\section{Origin of the Flora.}

The origin of the algal flora at present found in the Survey area is a subject as to which we have very little to guide us. The source of the Clare Island flora as distinct from the mainland presents, of course, no difficulty, whatever view be taken as to the date and manner of the formation of the island. But any theory as to the origin of the marine flora of the west of 
Ireland must be highly speculative, since our knowledge of the rapidity with which algae extend their range is very meagre, and fossil evidence (with regard to our area) is absolutely wanting. For this reason the most important data are those furnished by the study of the general distribution of the species, and by a recognition, if possible, of the presence of any definite phytogeographic groups. Börgesen ('05, p. 805) has summarized the views propounded by Kjellmann and Reinke as to the origin of the North Atlantic algal flora, which, in a word, is said to consist of a mixture of old atlantic and arctic elements. The question of the survival of plant-life in Ireland during the Ice Age, as to which there is so much difference of opinion, I leave to others, and will confine my remarks to phytogeographic observations, and to features in the Clare Island flora which appear to be of interest. Such may he of service to those engaged in the study of the antecedents of the present Irish fauna and flora.

Although the flora contains a decidedly larger proportion of southern forms than corresponding areas in England and Wales, there appears to be no element, such as is found amongst Phanerogams, which is strikingly austral. The southern species extend, probably without exception, along the south Irish coast, and are found in Devon, Cornwall, and Brittany; many also occur in the Bay of Biscay and on the north coast of Spain. Their range being continuous is, therefore, not remarkable. No notably Spanish or Mediterranean species are found. A boreal element of a special character is, on the other hand, recognizable, the abundance of Callithamnion arbuscula and Ptilota plumosu being very striking in an area where the general facies is of a much more southern type. Neither of these species occurs in the south of England, nor have they been recorded south of Yorkshire and Anglesea. Their position on the Irish west coast is, however, not isolated, but is merely a continuous southern extension of their range. But, as a result, there is in the marine flora, as in the terrestrial, a distinct mingling of north and south. Other boreal algae might be mentioned; but these are not so aluundant, nor has their distribution been so carefully ascertained.

The presence on the west coast of Ireland of a boreal element which is absent from the south of England, is a familiar problem to the Irish botanist. In the case of the algae cited above, the question of a land-connexion between England and Ireland need not be discussed, since the plants already occur in the northern part of Great Britain. It would appear, therefore, that the climatic or other conditions of the southern counties are unfavourable for the growth of these species. With regard to climatic factors, it is well known that extremes are more important than the mean; and from this we might conclude that, in the equable climate of Ireland, the maximum temperature 
which the plants can endure is not reached during summer, but that in the south of England this point is exceeded. The meteorological office reports show, however, that though the atmospheric temperature in S.W. England exceeds in summer that of S.W. Ireland, the sea-temperature is practically the same. ${ }^{1}$ The temperature factor then may explain the absence of the littoral $C$. arbuscula, but hardly that of the sub-littoral Ptilota. The physical nature of the coast has also to be considered. Both the algae mentioned require rocky ground. Ptilota grows on the stipes of Laminaria Cloustoni (a stout species demanding a very firm bottom); and $C$. arbuscula is found only on exposed rocks in the littoral region: from shores of sand, shingle, or soft lock they would therefore he absent. On the east of England, stretches of hard rock in the four counties immerliately south of Yorkshire are very scarce; and it is most probable that both plants would extend much further south were such rocks available. For Wales and S.W. England, however, this difficulty does not exist.

Another theory that presents itself is the possibility that, owing to more recent geographical changes in the English coast-line, C. arbuscula and P. plumose are still advancing in the Irish and North Seas, and that they have not yet reached their southern limit. The conditions (e.g., currents, nature of coast, etc.) may have been less favourable to their progress than in Ireland. This, however, is improbable, as the dispersal of marine algae by spores appears to be an easy and comparatively rapid process. Ptilota, moreover, is readily transported, being found washed ashore in abundance, and often in a bleached state. Such specimens (which are possibly of distant origin) frequently possess cystocarps containing presumably healthy spores. Currents do not appear to offer any resistance to the southern advance of algae in the Irish Channel.

From these considerations it is probable that the geographical theory does not meet the case, and that ecological factors are more likely to explain it. If this be so, the scarcity of hard rocks may have limited the range of these boreal species in the North Sea; and a high summer temperature may have prevented Callithamnion abuscula from settling down on our south-west coast. Ptilota remains a puzzle. Numerous points present themselves which would be worthy of inquiry; but with its precise distribution in Wales and Ireland uncertain, these must be left for future consideration.

The only geographic types recognized worthy of discussion here are the

\footnotetext{
I The average sea-temperatures for the past five years for Seafield (Co. Clare) and Plymouth during the summer months are almost identical. But during 1911 the Plymouth arerage from July 15 to September 9 was distinctly higher. The more eastern counties (Kent, Sussex) possess a much higher sea-temperature in summer than Devon and Cornwall.
} 
austral and southern elements dealt with above; but a further word may be said as to the comparison between the east and west coasts of Ireland. As far as can be seen from records, and from a study of herbarium material, the east-coast flora is characterized not so much by a poverty of species as by a smaller proportion of the austral element, and by a lack of the special luxuriance characteristic of the west. It appears useless at present to attempt to pronounce an opinion as to the origin of the species on either coast. The fact that Colpomenia sinuosa can suddenly appear in Brittany and Cornwall, and in the course of a few years be completely maturalized over a very large area on both sides of the English Channel, proves how quickly changes may take place, and how easily we may err in discussing the age and history of a flora.

There remain two isolated species to be noted. Bonnemaisonia hamifera, a fairly conspicuous and ummistakable alga, is elsewhere in Europe known only from a few stations on either side of the English Channel. It occurs in the North Pacific (Japan and California), and has usually been regarded as an alien in this country. The plant is dealt with on p. 136; but nothing can be stated as to origin in Clare Island, owing to our complete ignorance of its range in Ireland. Codium mucronatum var, atlanticum is even more noteworthy. So closely allied to the New Zealand form of the species as to be almost inseparable from it, and yet unknown in the northern hemisphere except in the British Isles, its distribution is certainly remarkable. As far as is known, it does not occur in England, but has existed in Scotland for at least seventy years, and in Ireland for upwards of a hundred. Its precise range has not yet been ascertained. Until each species of our flora is recognized, and until its range is accurately determined, plenty of work remains for the systematic algologist. Common species need not be despised. On Clare Island some of the most abundant and conspicuous algae have proved the most interesting; and yet, owing to lack of data concerning their distribution, we are hampered in drawing theoretical conclusions.

\section{V.-BIBLIOGRAPHY.}

Adass, J. ('08). A Synopsis of the Irish Algae. Proc. Roy. Irish Acad., xxvii B, No. 2, p. 11.

('10). A list of Synonyms of Irish Algae with additional records and observations. Proc. Roy. Irish Acad., xxviii B, No. 5, p. 167.

('12). A census of Irish Cryptogams. Irish Nat., xx, p. 87. 
BAKER, S. M. ('09 \& '10). On the causes of the Zoning of Brown Seaweeds. New Phytol., viii, p. 196, ix, p. 54.

('11). On the Brown Seaweeds of the Salt Marsh. Journ. Linn. Soc., xl, p. 275.

Batrens, E. A. L. ('89). Marine Algae of Berwick-on-'Tweed. Transactions Berwickshire Naturalists' Club.

('91). Handlist of the Algae of the Clyde Sea Area. 25 pp. Reprinted with additions from Journ. Bot., xxix, p. 209.

('96). Some New British Marine Algae. Journ. Bot., xxxiv, p. 6.

('00). New or Critical British Marine Algae. Journ. Bot., xxxviii, p. 369.

('02). A Catalogue of the British Marine Algae. Supplement to Journ. Bot., xl.

('07). A preliminary List of the Marine Algae of Lambay. Irish Nat., xvi, p. 107.

Berthold, G. ('82). Über die Vertheilung der Algen im Golf von Neapel. Mitt. aus d. zool. Station zu Neapel, iii. Band.

Bökgesen, F. ('00). The Marine Algae-Vegetation ... of the Danish West Indian Islands. Bot. Tidssk., xxiii, p. 49.

('01). An ecological and systematic account of the Caulerpas of the Danish West Indies. Kgl. Danske Vidensk. Selsk. Skrifter, 7 Rk., Naturv.Mathem., Afd. N. 5.

('02-'03). Marine Algae. Botany of the Faeröes, Part II, p. 339.

('03). The Marine Algae of the Shetlands. Journ. Bot., xli, p. 300.

('05). The Algae-Vegetation of the Faeröese Coasts. Botany of the Faeröes, Part II, p. 683.

('11). The Algal Vegetation of the Lagoons in the I)anish West Indies. Biol. Arbejder. tilegnede Eug. Warming., p. 41.

Börgesen, F., and Helgr Jóssson ('05). The distribution of the Marine Algae of the Aretic Sea, and of the northernmost part of the Atlantic. Botany of the Faeröes, Appendix, p. 1.

Bоге, P. ('94-'95). Bidrag til kundskaben om Algevetationen ved Norges vestkyst. Bergens Museums Aarbog., xvi.

Chalon, J. ('05). Liste des Algues Marines . . . entre l'embouchure de l'Escaut et la Corogne. Anvers.

Coluins, F. S. ('09). The Green Algae of N. America. Tufts College Studies, ii, No. 3.

Cotron, A. D. ('07). Some British Phoeophyceae. Journ. Bot., xlv, p. 368.

('08). The appearance of Colpomenia sinuosa in Britain. Kew Bulletin, 1908, No. 2, p. 73. See also Journ. Bot., xlvi, p. 82.

('09). Notes on Marine Pyrenomycetes. Trans. Brit. Myc. Soc., iii, p. 92.

('11). On the increase of Colpomenia sinuosa in Britain. Kew Bull., 1911, No. 3, p. 153. 
Cotron, A. D. ('11 b). On the growth of Olva latissima, in excessive quantity, with special reference to ... Belfast Lough. Botanical Report. Royal Commission on Sewage Disposal, 7th report, Appendix iv, pp. 121-142.

Darisishire, O. V. ('02). Chondrus. Liverpool Mar. Biol. Comm. Memoir No. 9, London.

De Toxi, J. B. ('89-'05). Sylloge Algarum omnium hucusque cognitarum. Batavii. Falkenberg, P. ('01). Die Rhodomelaceen. Zool. Stat. zu Neapel, Mono. graphie No. 25. Berlin.

Fosıre, M. ('94). New ol critical Norwegian Algae. Kgl. norske Vidensk. Selsk. Skrifter, Trondhjem, 1894, p. 3.

('99). A visit to Roundstone in April. Irish Nat., viii, p. 175.

Grbson, R. J. Hartey, and H. P. Auld ('00). Codium. Liverpool Mar. Biol. Comm., Memoir No. 4. Liverpool.

Gosroxt, M. Monographie des Oscillariées. Ann. Sci. Nat., Bot., (7), xv et xvi.

Gockн, L. H. ('06). Plankton collected at Irish Light-Stations in 1904. Dept. Agric., Ireland, Fisheries Branch, Sci. Invest., vi.

Grav, H. H. ('93). Algevegetation i Tonsbergfjorden. Christ. Vidensk. Selsk. Forhandl.

Harna, H. ('98). Seaweeds of Achill. Ir. Nat., vii, p. 142.

Haxstees, Barthold ('92). Algeregioner og Algeformationer ved den norske vestkyst. Nyt Magazin for Naturvidenskaberne, xxxii, Christiania.

Harvey, W. H. ('46-'51). Phycologia Britannica. 4 vols. London.

Hexkes, I. ('06). A study of Tide-pools on the west coast of Vancouver Island. Polstelsia, 1906, p. 277.

HıL, T. G. ('09). The Bouche d'Erquy in 1908. New Phytol., viii, p. 97.

Holses, E. M., and E. A. L. Batrers ('90). A revised List of the British Marine Algae. Ann. Bot., v, p. 63. Appendix, p. 518.

Johssох, N. M. ('10). A method of mapping the distribution of Marine Algae. Scott. Geogr. Mag., xxvi, p. 598.

('12). Ecological terminology applied to Marine Algae. Scottish Botanical Review, vol, i, p. 44.

Jonnson, T. ('y3). A visit to Roundstone. Irish Nat., ii, p. 313.

Johrson, T., H. Hanna, R. Hensman, and M. C. Knowles ('99). Irish Phoeophyceae. Proc. Roy. Irish Acad. (3), v, p. 441.

Johnson, T., and R. Hensaran ('99). A list of Irish Corallinaceae. Sci. Proc. Roy. Dub. Soc., N.S., ix, Part 1, p. 22.

Júnsson, H. ('02-'08). The Marine Algae of Iceland., I-IV. Bot. Tidsskr., xxiv-xxr.

('10). On Algevegetationen red islands Kyster. Bot. Tidsskr., xxx, p. 223.

Joubra, L. ('09). Recherches sur la distribution océanographique des végétaux marins ... de Roscoff. Ann. de l'Institut Océanographique, Tome I, fase, 1 , 
Kjellaran, F. R. ('77). Ueber die Algenvegetation des Murmanschen Meeres. Nova Acta Reg. Soc. Ups., Ser. III, Upsala.

(78) Über Algenregionen und Algenformationen im östlichen Skager Rack. Bihang till K. Svenska Vet. Akad. Handlingar, Band v. No. 6.

Kuckuck, Paul ('97.) Über die Algenvegetation von Helgoland. VerhandJ.d.k.k. zool.-bot. Gesellsch. in Wien, Band 47, p. 51.

('97). Über Marine.Vegetationsbilder. Berichte d. deutsch. bot. Ges., xv, p. 441.

Kruin, H. ('07). Studien über die Algenflora der schwedischen Westküste. Upsala.

('10). Zur Kenntnis der Algenflora der norwegischen Westküste. Archiv fïr Botanik, x, No. 1, p. 1.

LE Jours, A. ('63). Liste des Algues marines de Cherbourg. Paris et Cherbourg. Lemone, Mme. P. ('10). Essai de classification des Mélobésiées basée sur la structure anatomique. Bull. Soc. bot. de France, lvii ([4] x), p. 323.

('10 b). Réparition et mode de vie du Maërl. Ann. de l'Institut océanographique, Tome I, fasc. 3.

('11). Structure anatomique des Mélobésiées. Idem, Tome II, fasc. 2, $213 \mathrm{pp}$.

('11 b). Le rôle des Algues dans la formation des dépôts calcaires. Rev. Gen. des Sciences, Année xxii, No. 6.

Letts, E. A., and E. H. Richards ('11). On Green Seaweeds in relation to the Pollution of the Waters in which they occur. Royal Commission on Sewage Disposal, 7th report, Appendix iii, p. 72.

Menz, J. ('10). Ueber sekundäre Befestigung einiger Rotalgen. Oesterr. Bot. Zeit., lx, p. 103.

Nordhausen, M. ('99). Zur Anatomie und Physiologie einiger rankentragender Meeresalgen. Jahrb. f. wiss. Bot., xxxiv, p. 236.

Ostenferd, C. H. ('08). On the Ecology and Distribution of the Grass Wrack in Danish Waters. Report of the Danish Biological Station, xvi.

Petersen, H. E. ('11). Ceramium Studies, i and ii. Bot. Tidsskr., Bind 31, p. 97.

Rattray, J. ('86). The distribution of the Marine Algae of the Firth of Forth. Trans. Edinb. Bot. Soc., xvi, p. 420.

Reinke, J. ('89). Algenflora der westlichen Ostsee dentschen Antheils. VI. Bericht der Kommission zur Untersuchung der dentschen Meere. Kiel.

('92). Atlas dentscher Meeresalgen. Berlin.

('92 b). Gäste der Ostseeflora. Berichte d. deutsch. bot. Gesellsch., x, p. 4. Rosenninge, L. Kolderup ('94). Les Algues Marines du Groenland. Ann. Sci. Nat., Bot., (7), xix, p. 53.

('98). Deuxième Mémoire sur les Algues Marines du Groenland. (Meddelelser om Gronland, xx). 
Rosestrise, L. Kolderup ('99). Sur' la végétation d'Algues marines sur les cótes du Groonland. (Idem, p. 339.)

('09). The Marine Algae of Denmark. Part 1. D. Kgl. Danske Vidensk. Selfk. Skrifter, R. 7. t. vii.

Sauvagedu, C. ('97). Note préliminaire sur les Algues marines du Golfe de Gascogne. Journ. de Bot., xi, p. 166.

('97). Sur quelques Myrionémacées. Ann. des Sci. Nat., Bot., (8), v, p. 161.

('06). A propos du Colpomenia sinuosa signalé dans les huitrières . . . de Vannes. Bull. Sci. d'Areachon, ix, p. 35.

('08). Sur deux Fucus récoltés à Arcachon. Soc. Sci. d'Arcachon, Travaux des Lab., Année xi, p. 65.

Schller, J. ('09). Ueber Algentransport und Migrationsformationen im Meere. Internat. Rer. der gesamten Hydrobiologie und Hydrographie, Band ii, p. 62.

SEWARD, A. C. ('94). Algae as rock-building organisms. Science Progress, ser. i, vol. ii, p. 10.

Simsons, H. G. ('97). Zur Kenntnis der Meeresalgen-Flora der Faeröer. Hedwigia, xxxvi, p. 247.

SkINiner, S. A. ('03). Observations on the Tide-pool Vegetation of Port Renfrew. Minnesota Bot. Studies, (3), ii, p. 145.

Skottsberg, C. ('06). Observations on the Vegetation of the Antarctic Sea. Bot. Stud. tillägnade F. R. Kjellman, p. 245. Upsala.

Stanford, E. C. C. ('84). Economic Aspects of Seaweeds. Journ. Soc. Arts, xxxii, p. 717. Reprinted in Journ. Pharm. Soc., (3), xiv.

Sredelius, N. ('01). Studier öfver Ostersjöns Hafsalgtlora. Akademisk. Aflrandling. Upsala.

('06). Über die Algenvegetation eines ceylonischen Korallenriftes. Bot. Stud. tillägnade F. R. Kjellman, p. 184. Upsala.

Tanstey, A. G. ('11). Types of British Vegetation. Cambridge.

Teсket, K. ('06). Ueber die Marine-Vegetation des Triestes Golfes. Abh. d. k. k. Zool. Botan. Ges. in Wien, iii, Heft 3.

Tobler, F. ('06). Zur Biologie der Epiphyten im Meere. Berichte d. deutseh. bot. Ges., xxiv, p. 552 .

Weber Van Bosse, A., and M. Fostie ('04). The Corallinaceae of the Siboga Expedition, Monograph lxi. Leyden.

W'erss, F. E. ('00). Algae of Valencia Harbour. Proc. Roy. Irish Acad. (3), v, p. 799.

Wrute, N. ('10). Algologische Notizen, xvi-xxi. Nyt. Mag. f. Naturvidensk., B. 48 . 


\section{DESCRIPTION OF PLATES.}

\section{Plate I.}

Porphyre "mbilicalis association on south shore of Clare lsland in July (1910). The Porphyra belt at this spot takes the place of Fucus spiralis, and occurs between the bands of Pelvetia and F. vesiculosus, var. evesiculosus. It is thus somewhat higher than usual. The shore is exposed and rather steep.

\section{Pisate II.}

Bottder-beach between I'ortlea and the lighthouse, showing broken character of zones and associations. The Pelvetia belt is practically absent, and the zones of Furvs sprivalis and $F$. vesiculosus which follow are interrupted and discontinnous. In the foreground Himanthalia with the usual undergrowth of Lamencia pinntifida is seen, and also the beginning of the $F$. serratus regetation. Gigartina joins the Lanrencia band in the lower levels, and Rhodymenia polmutr hangs from the shady sides of boulders.

\section{Plate III.}

Shallow rock-pool on south shore, half-tide level. Showing more or less continuous covering of Lithophyllum incrustens with characteristic lip-like protuberances (centre). Several tufts of Polysiphonia fruticulosa occur, and in the upper left-hand corner Corallina officinalis and the more southern (. squamatre are seen together. To the extreme right is Polysiphonia Brodiaei (upper cornet). In pools of this kind small plants of Codium mucronatum var, oflunticum are frequent.

\section{Plate IV.}

"Coral beaches" in Manuin Bay, Co. Galway. The white sand of the beach is composed of finely broken fronds of Lithothamnium calcareum, which are washed ashore from the Lithothamnium association in the Bay. In some beaches a few rocks are present, but these are largely devoid of algae (fig. 2). The weed washed ashore in foreground is Zostera. Photographed at lowwater by Dr. G. H. Pethybridge, October, 1911.

\section{Plate V.}

FIG. 1.-Lithothamnium sand from Mannin Bay. Medium-grained sand frcm the middle part of the beach (nat. size). At high-water mark the sand is rery coarse, and contains shells and Lithothamnium knolls; at low-water it is extremely tine, and its origin is hardly discernible without a microscope. 
FIG. 2.- "Fucus farm" in Achill Sound. Photograph of Blind Sound (near Darby's Point) at low-water, showing stones with growth of Fucus. The stones are set ont (often in regular rows) by the cottagers, and become rapidly colonized by Fucus vesiculosus, whjch, at the end of the second season, is cut for use as manure.

\section{Plate VI.}

Fucrus vesiculosus var. muscoides var. nov.

FiG. 1.-Dried specimens of individual plants (slightly less than natural size). The specimens in the two upper rows are from the dense mossy growth seen in fig. 2; those from the lower are from the margins of such growth, where increased space and moisture allow of better development. In the lowermost specimen to the right two male receptacles are recognisable.

FIG 2.-Small piece cut out from var. muscuides sward in Achill Sound. The sward forms a narrow irregular zone in several parts of the Sound. It is more or less mixed with Strtice maritima, Glyceria maritima, Salicornia, spp., etc., and in the month of May is particularly attractive, owing to the bright pink flowers of the first-named. Photo by Mr. G. Massee of tuft brought back to Kew (slightly reduced).

\section{Plate VII.}

Codium mucronatum var. atlanticum var. nov., with a fragment of C. tomentosum (nat. size). The drawings are made from dried specimens; but the thick branches and robust habit of $C$. mucronatum are noticeable. In the living state the plants can readily be distinguished by this character; but in dried specimens it is necessary to examine the utricles.

\section{Plate VIII.}

Utricles of Codium mucronutum and $C$. tomentosum.

1-2. C. tomentosum. Showing short utricles with the cell-wall thickened at the apex. (Clare Island, Oct., 1910.)

3. C. mucronatum var. atlanticum var. nov. Showing utricles double the length of those of $C$. tomentosum, and considerably wider; apex even or mucronate; not thickened as in C. tomentosum. (Giant's Causeway, May, 1910.)

4. C. mucronutum var.- atlunticum var. nov. Note drumstick utricle specially frequent in old plants. (Clare Island, April, 1909.)

5. C. mucronutum var. atlanticum var. nov., with gametangia ( $q$ ). (Roonah Quay, June, 1910.) 
6. C. mucronatum var. Novae Zelandiae. Note similarity of utricles to those of the Irish plant. (New Zealand, Herb. Kew.)

7. C. mucronutum var. trismanicum. Apex of utricle very pointed. (Tasmania, Herb. Kew.)

8. C. mucronatum var. californicum. Mucro long, blunt; often apparently articulate. (California, Herb. Kew.)

\section{Plate IX.}

Ptilothamnion lucifugum sp. nov.

1. Decumbent and upright fronds, showing irregularly produced branches and pinnae. (x c. 15.)

2. Part of a branch showing pinnae and forked pinnulae. The pinnae are occasionally opposite; but usually the opposite pinna remains practically undeveloped. $(\times 80$.)

3. End of pinna. $(\times 140$. $)$

4. Pinnulae with antheridia. ( $\times 140$.)

5-6. Part of decumbent branch showing rhizoidal pinnae, which occasionally terminate in a more or less discoid expansion. $(x 140$. $)$

\section{Plate X.}

\section{1-2. Calothrix endophytica sp. nov.}

1. Portion of Enteromorpha frond showing Calothrix filaments within the cavity. $(\times 400$.$) 2. Cluster of short filaments, with the basal$ heteroeysts (normal). ( $\times 500$.$) 3. Longer filaments, with basal and$ intercalary heterocysts. $(\times 500$.

4-9. Ascocyclus Saccharinue sp. nov.

4. Discoid thallus, easily separable into filaments. 5. Assimilating filaments and young ascocysts. 6. Assimilating filaments and young sporangia. 7. Sporangia and hairs, with basal sheath. 8. Sporangia, and two empty ascocysts. 9. Two ascocysts with contracted contents. $(\times 400$.)

10. Nitophyllum uncincum J. Ag., showing irregular fronds and acuminate branches. (Dried specimen, nat. size.)

11. N. laceratum var. uncinutum Grev. Quite distinct from the last, being merely a variety with uncinate branches of the common $N$. laceratum (nat. siże).

\section{Plate XI.}

Map of the Clare Island District. 


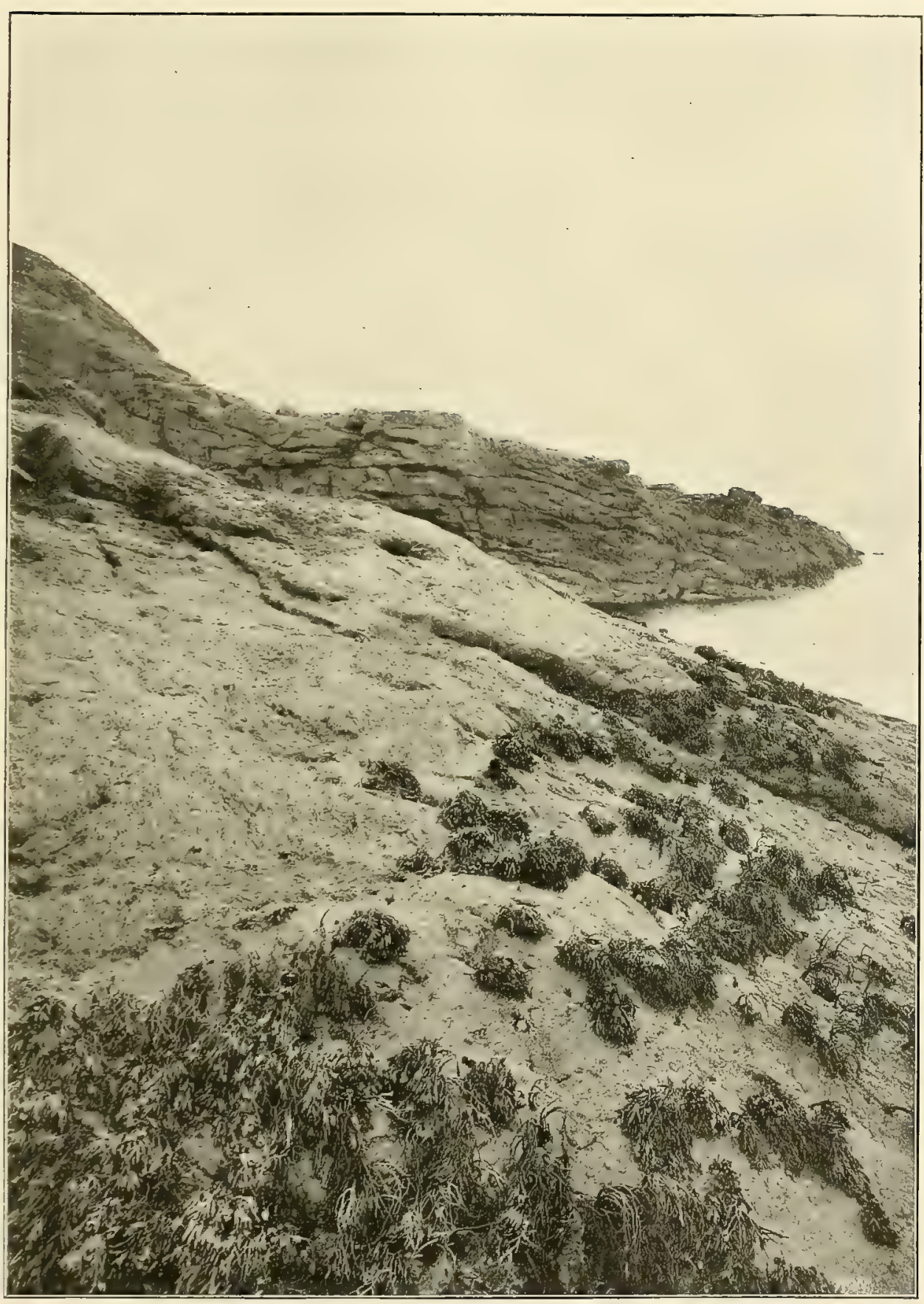

The Porpinyra association of exposed shores, Clare Island. R. Welch, photo. Clare Island Survey,-Cotton: Marine Algae. 



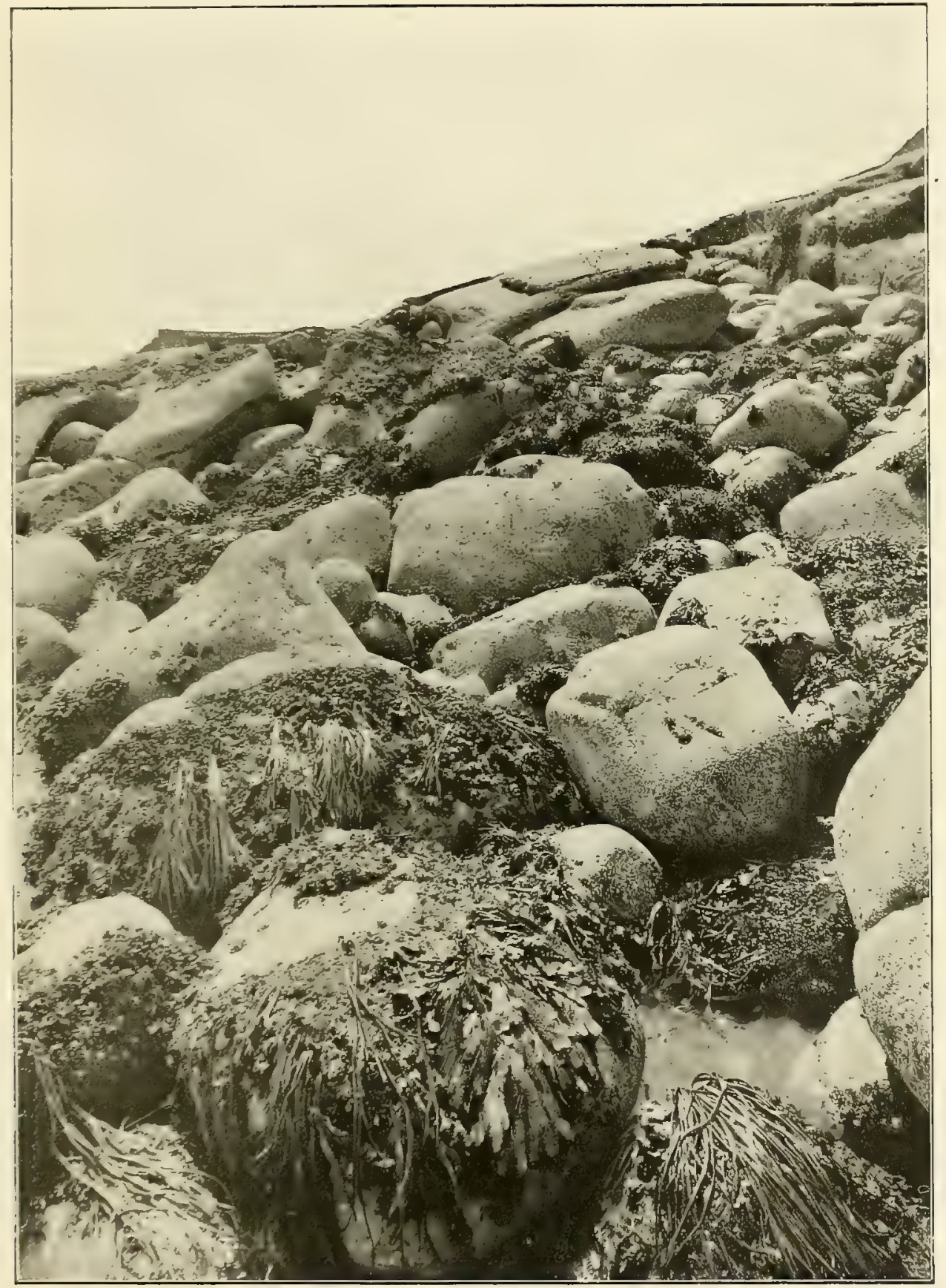

Boulcier Beach at Portlea, showing discontinuous zonation. R. Welch, plroto. Clare Island Survey,-Cotton: Marine Algae. 



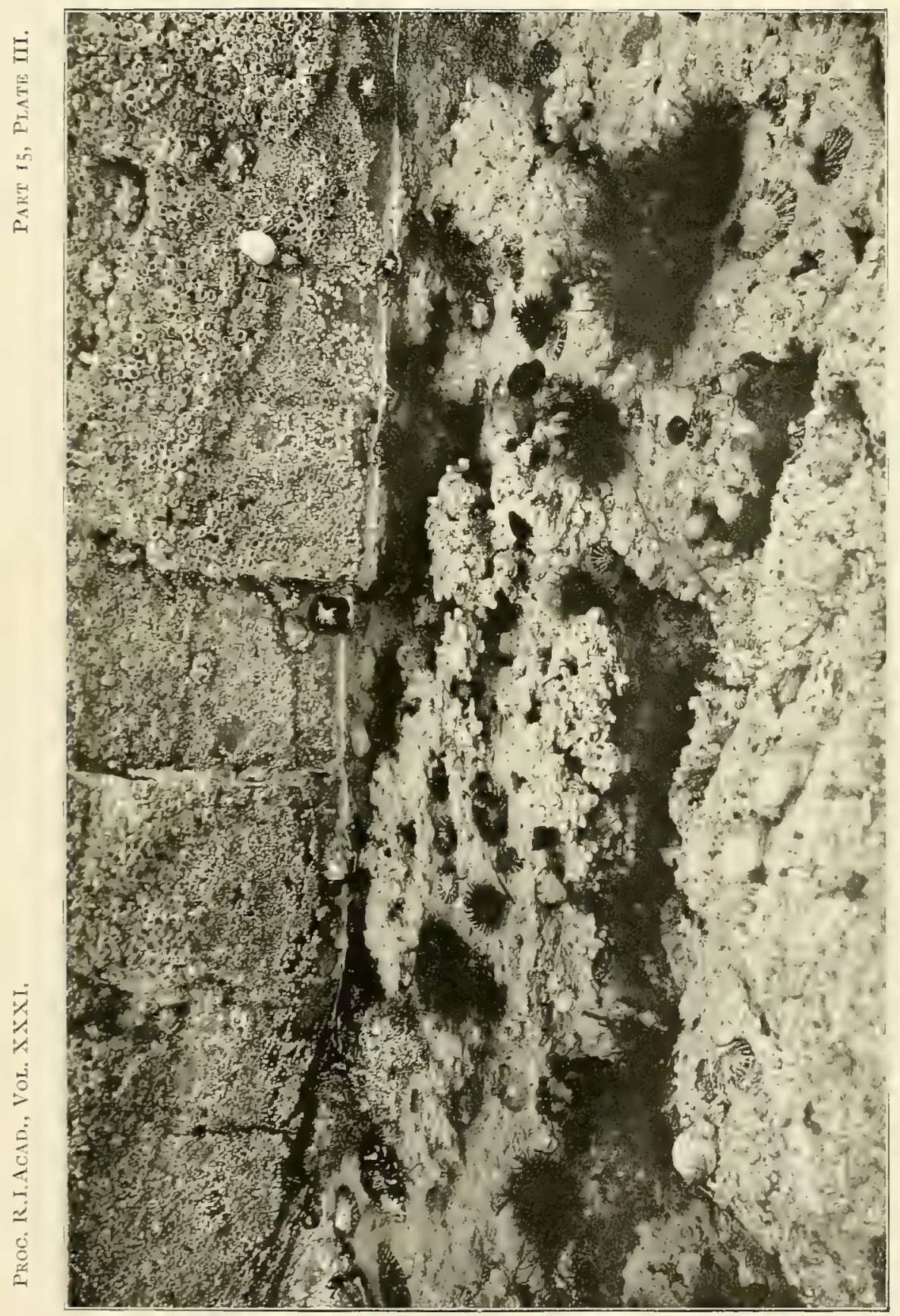

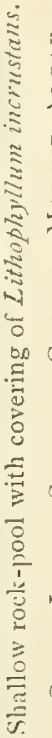





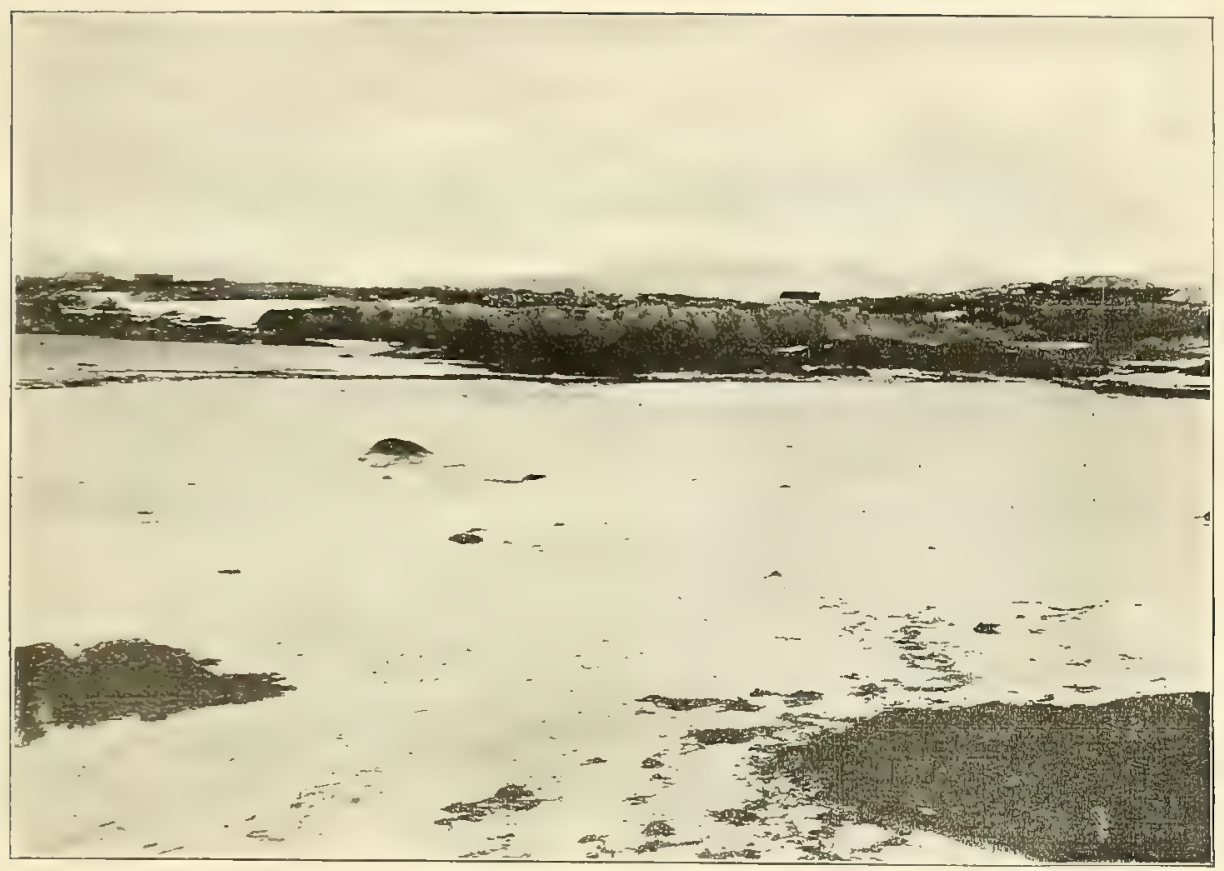

Fis. I.

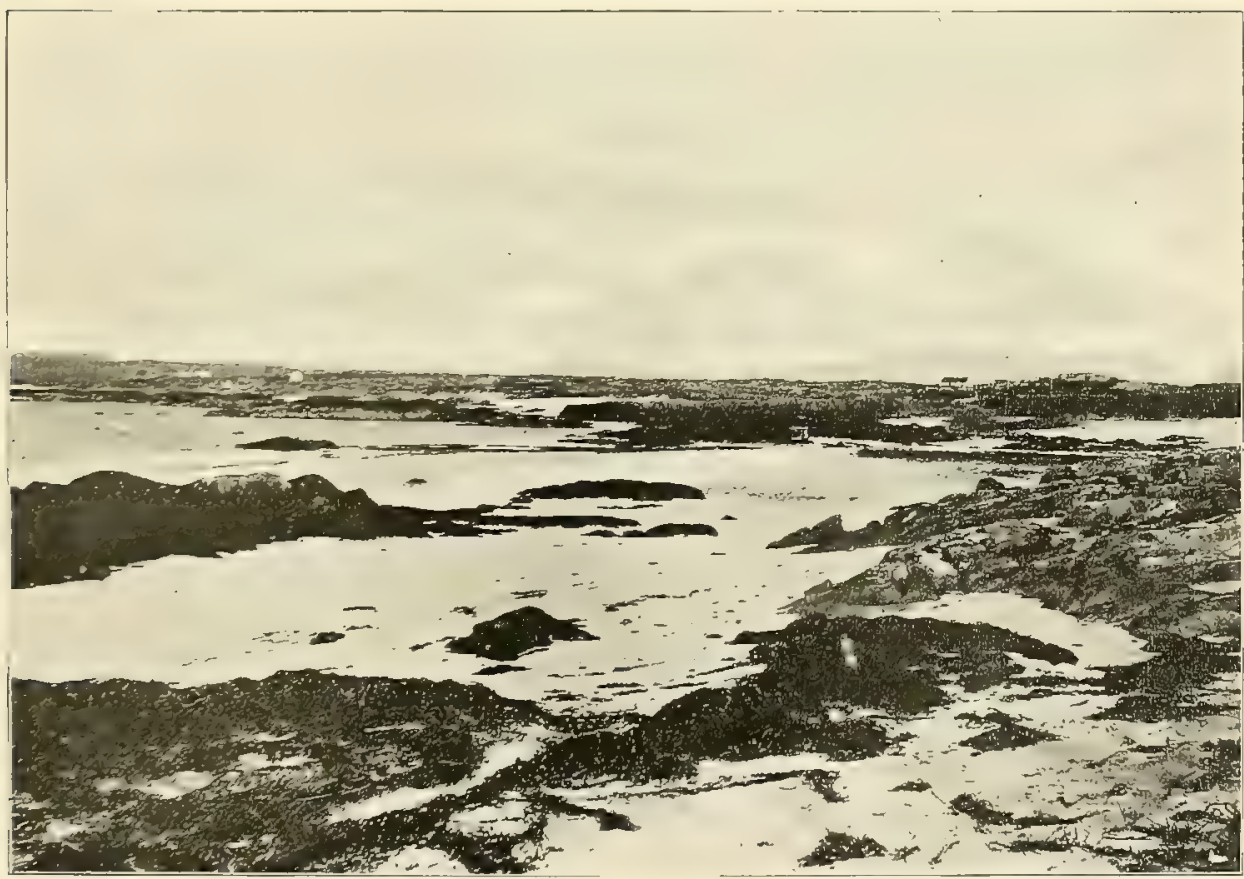

FiG. 2 .

G. H. Pethybridge, photo

"Coral Beaches" in Mannin Bay. Sand composed of broken fronds of Lithothamnizum calcareum. Clare Islani) Survey.-Cotton: Marine Algae, 



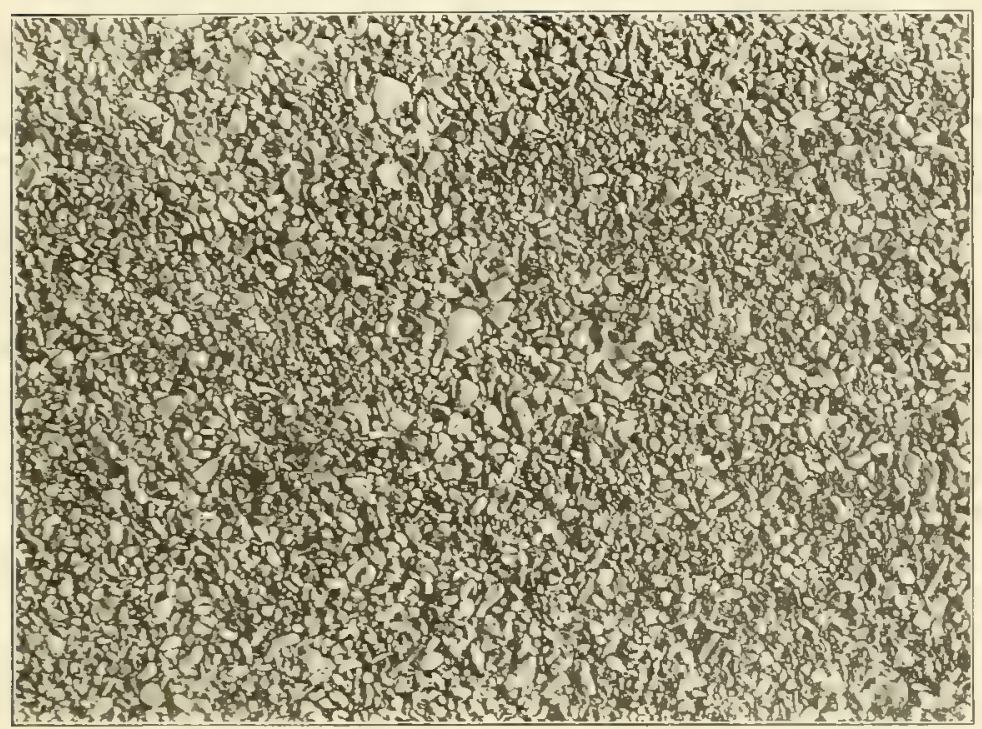

G. H. Pethybridge, photo.

FIG. I.-Lithothamnium sand from beach in Mannin Bay.

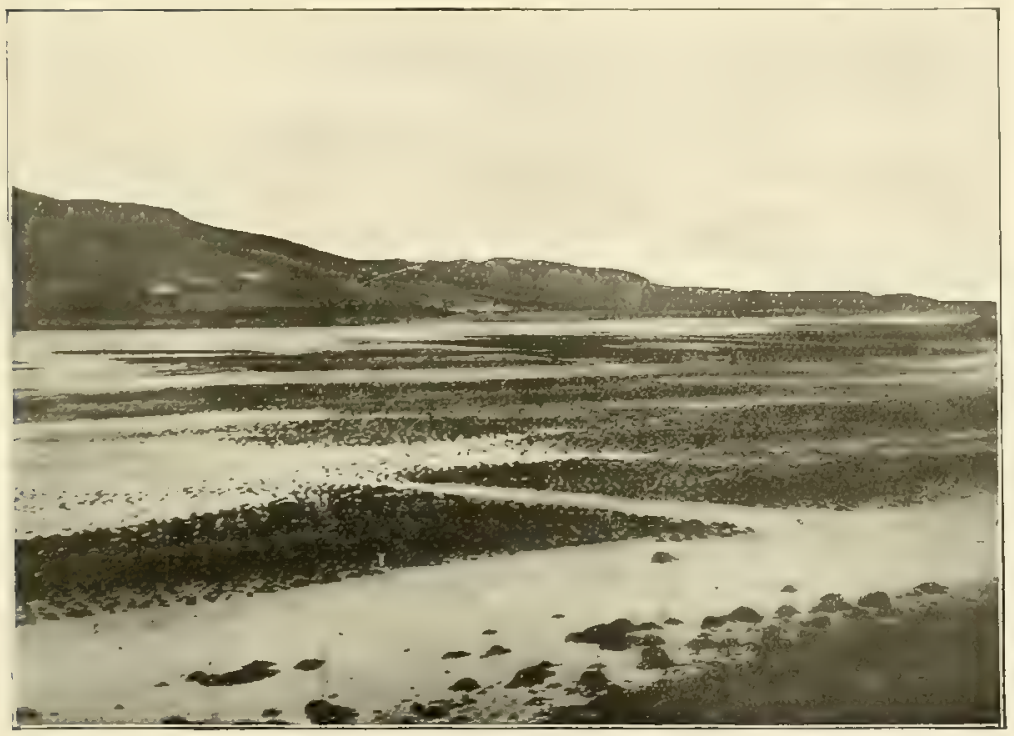

T. J. Westropp, photo.

FIG. 2.-Fucus farms in Achill Sound.

Clare Ireland Survey.-Cotton: Marlne Algae. 



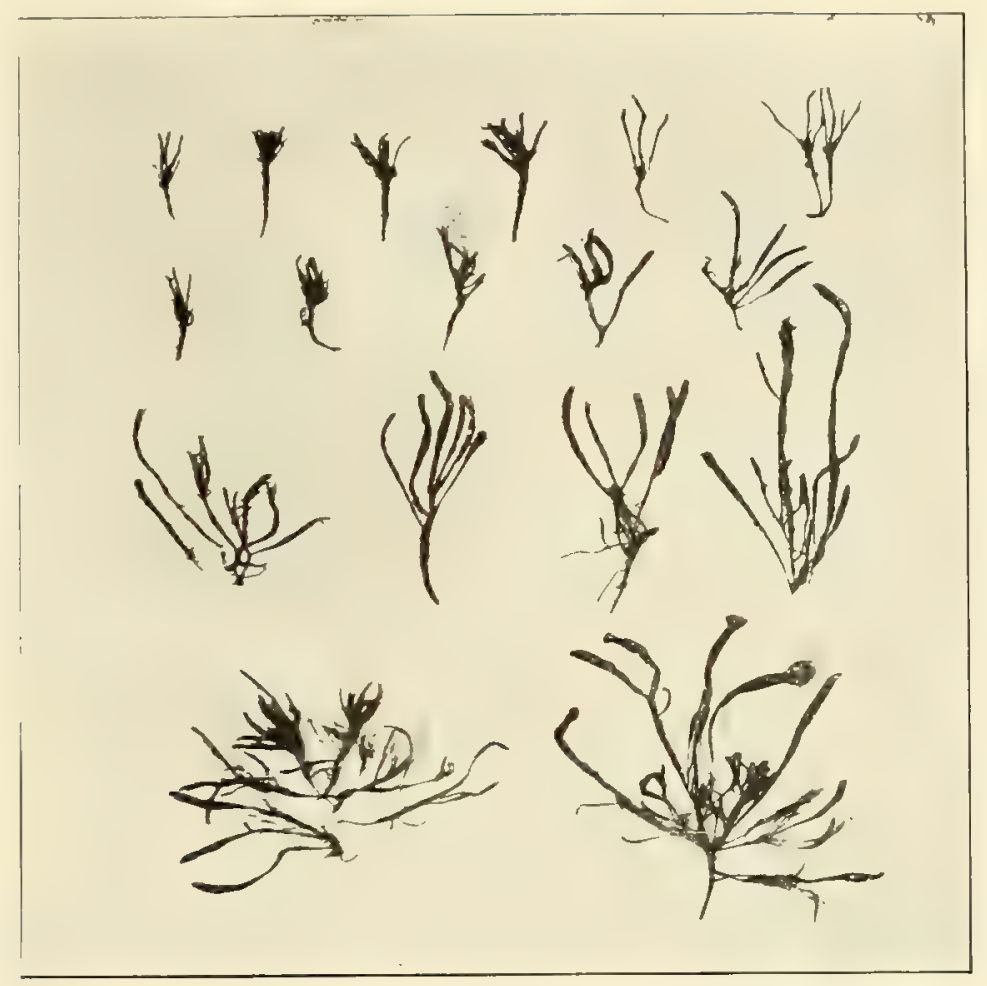

FIG. I.

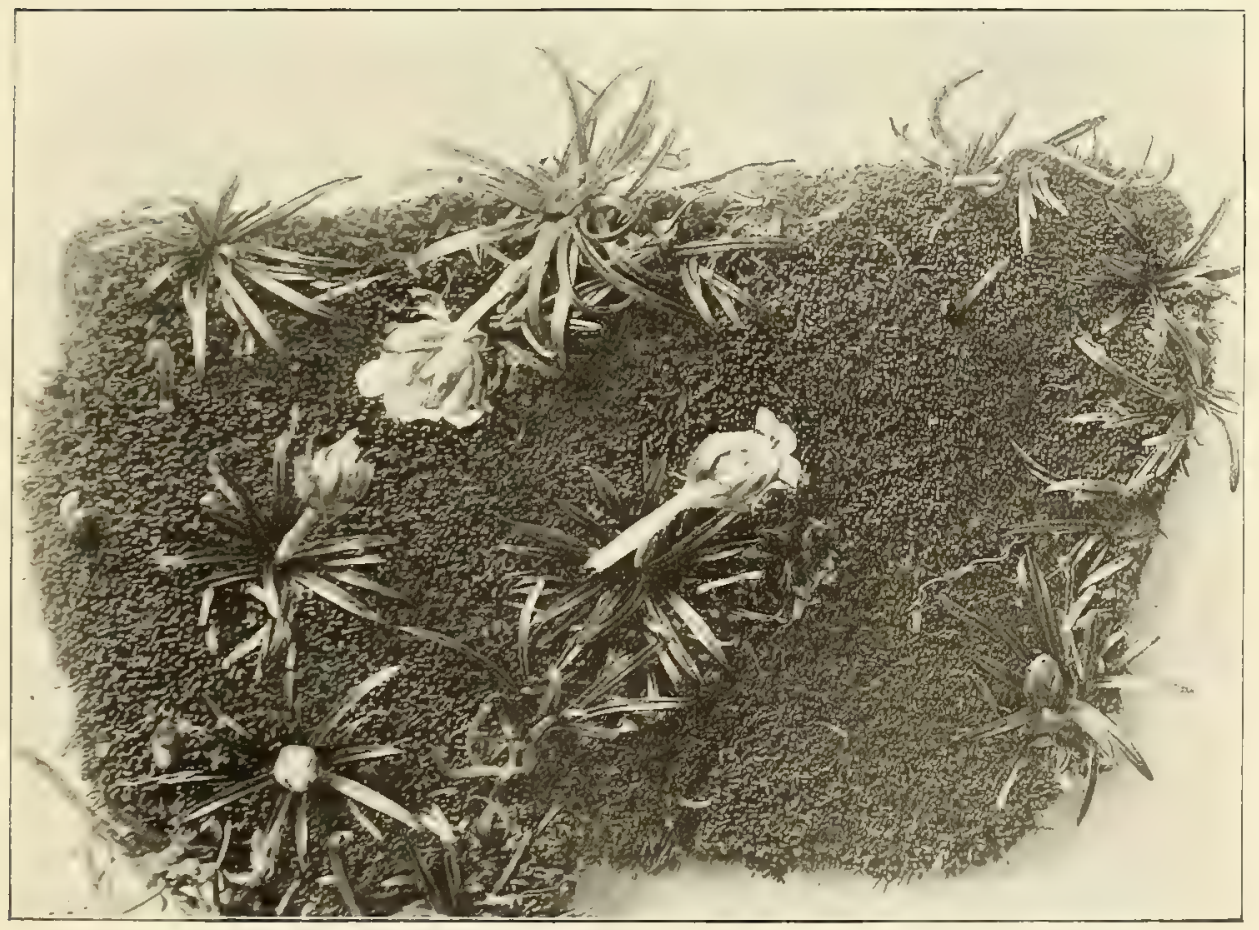

FIG. 2 .

G. Massee, photo.

Fucus vesiculosus var. muscoides var. nov.

Fig. I.-Individual plants. Fig. 2.- Sward formed by the same, with scattered plants of Statice maritima. 



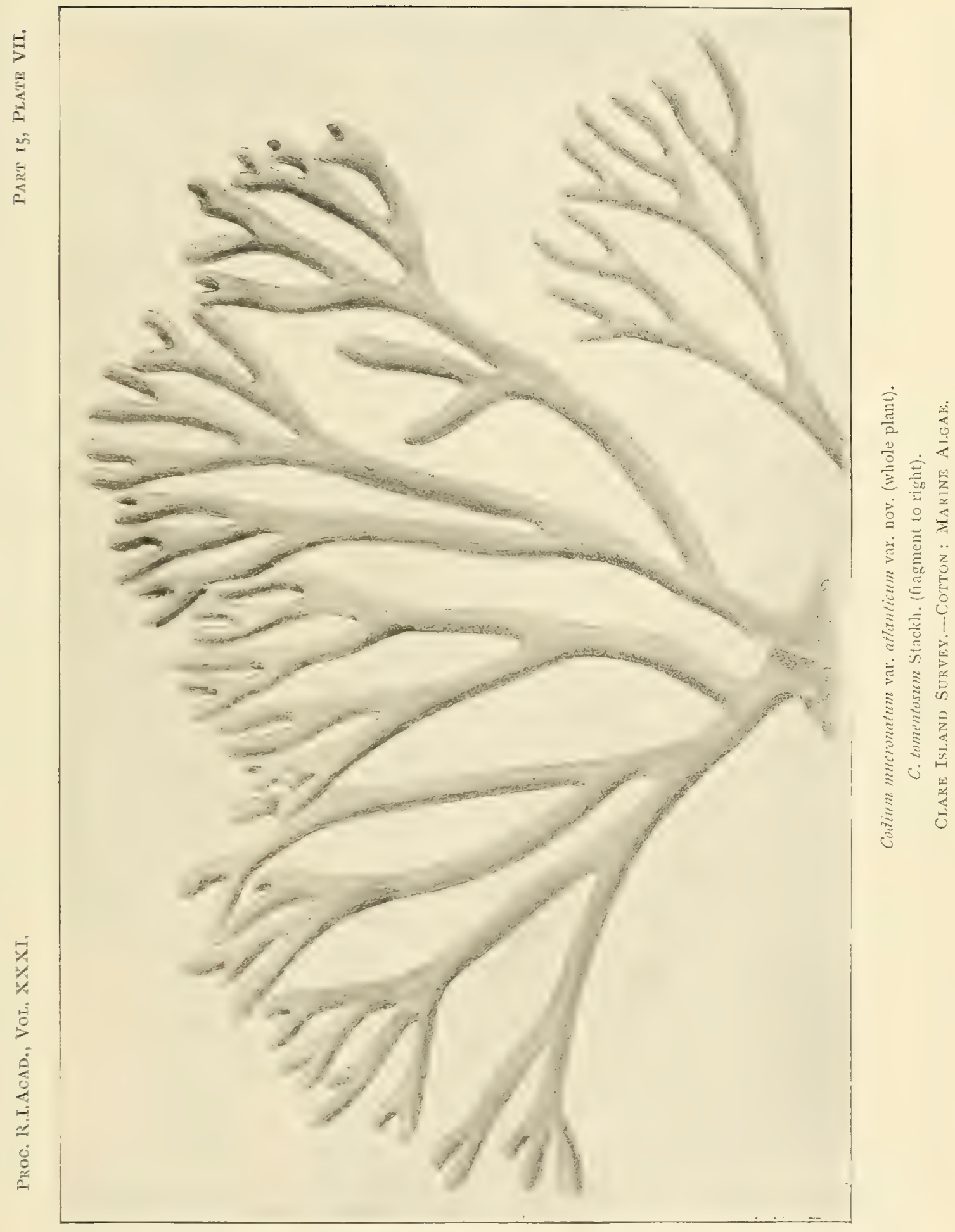



Proc. R.I.ACAD. VOL. XXXI.

PART 15, PLATE: VIII.
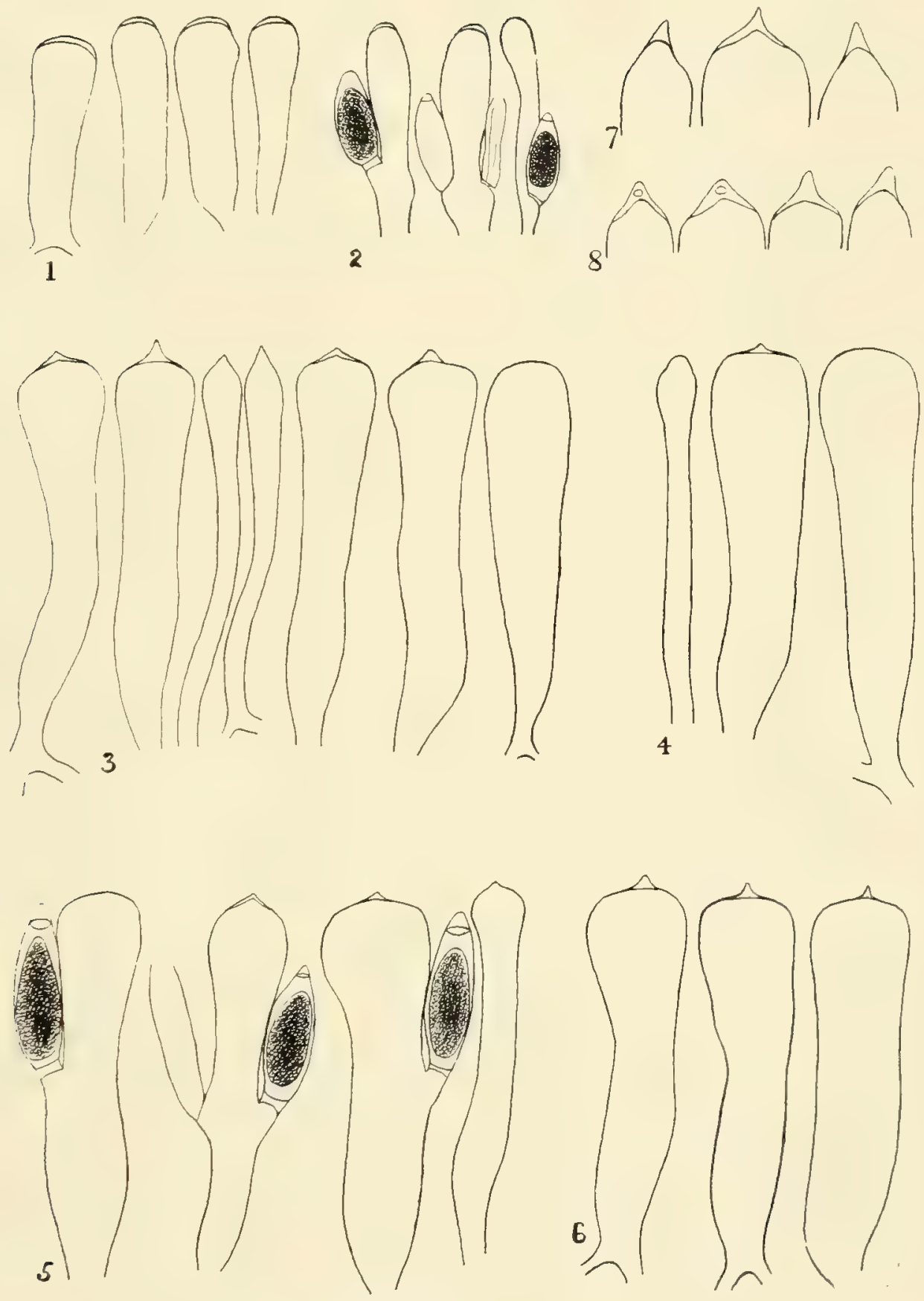

I, 2 Codium tomentosum.

3-5 C. mucronatum var. atlanticum.

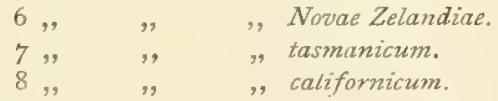

Clare Island Surver.-Cotton: Marine Algari. 



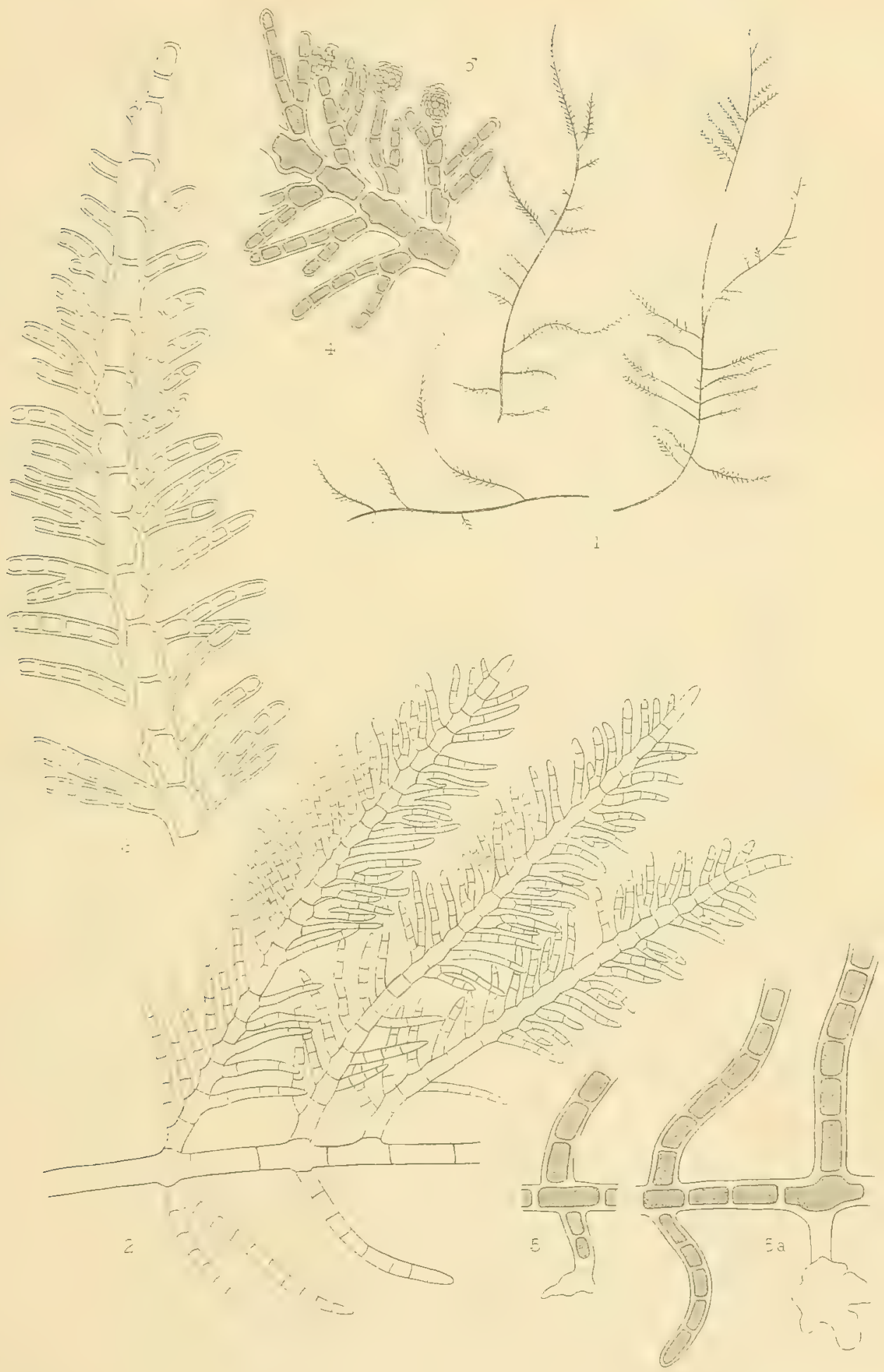





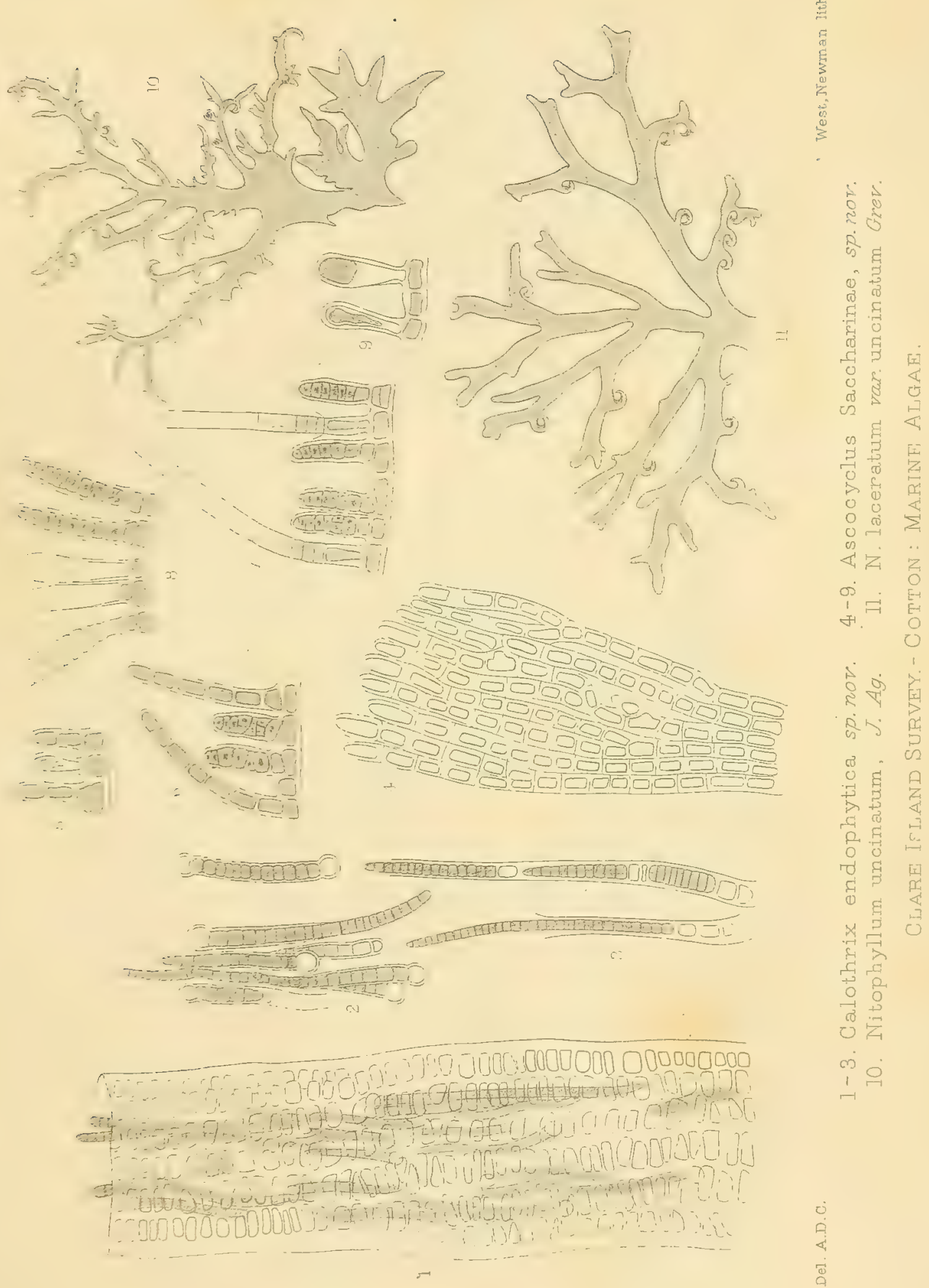





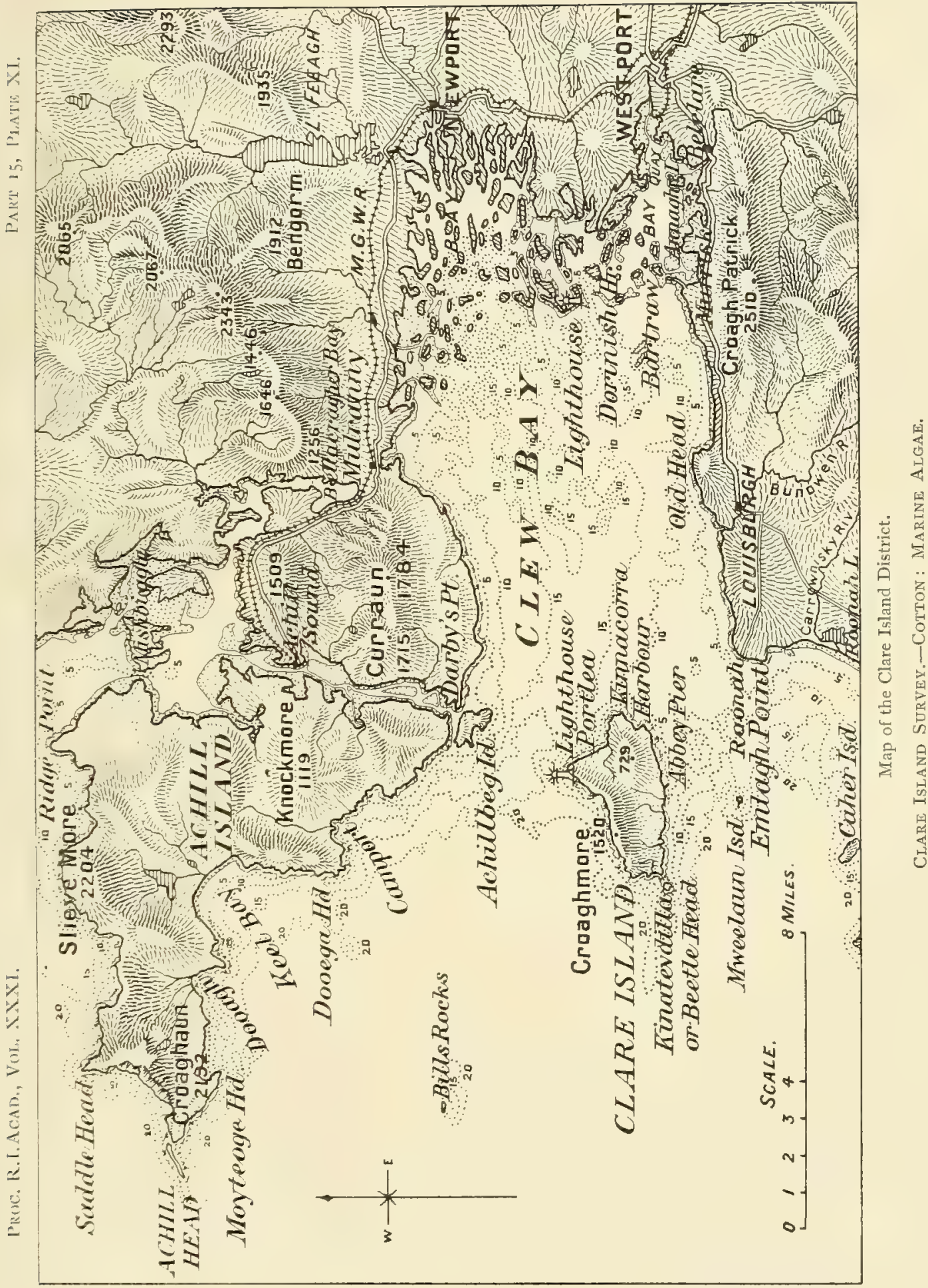




\section{SMITHSONIAN INSTITUTION LIBRARIES}

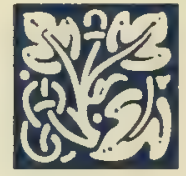

From the Library of

E. YALE DAWSON 


\section{ROYAL IRISH ACADEMY \\ CLARE ISLAND SURVEY}

SCHEME OF PUBLICATION

[The parts already published are marked with an asterisk. The whole will form

Vol. XXXI of the Proceedings of the Academy.]

PART

1 Grangrar Desomption, and Naprative. Ru Li. Praeger.

* 2 Histori and Aromanologx. T. J. Westropp. 78 pp. 10 plates. 4s.

3 Prace Names. John Mac Neill. T. J. Westropp.

* 4 Gafrio Plant and amtarar Nameg. N. Colgan. 30 pp. 6d.

* 5 Agrtoulturk. Prof, James Wilson. $46 \mathrm{pp}$. 1s.

6 Metrorology. W. J. Lyons.

7 Geouogr. J. R. Kilroe. T. Hallissy.

8 Peat Deposits. T.J. Lewis.

8 Trist-Growira. A, O. Forbes.

* 10 Pranerogamia añd Pteridophyta. R. Li. Praeger. 112 pp. 6 plates. 4s.

* 11 Musor. Rev. Oanon Lett. 18 pp. 6d.

* 13 Fuxar. Carleton Rea. Sir H. C. Hawley. 26 pp. 1 plate. 1s.

* 14 Lronastes, Annio Lorrain Smith. 14 pp. 6 d.

* 15 Ay.gas-Marnse. A. D. Cotton. $178 \mathrm{pp} .11$ plates. 5s.

* 16 Argaz-Fresh-watpor. William West. 62 pp. 2 plates, 2s.

* 17 Masrsacira. G. E. H. Barrett-Hamilton. 14 pp. )

* 18 Reptiria avd Aarpiubia. R. F. Scharff. 4 pp. $\} 6 \mathrm{~d}$.

* 19 Pisoes. G. P. Farran. 6 pp.

* 20 Aves. R. J. Ussher. $54 \mathrm{pp}$. 5 plates. $2 \mathrm{~s} .6 \mathrm{~d}$.

21 Tumicata and Hemrogorda. G. P. Famran. R. Southern.

* 22 Momeusoa-Mlarine. N. Colgan. $36 \mathrm{pp.} \mathrm{18.}$

* 28 Moliusoa-Luand and Fresh-Water. A.W. Stelfox. 64 pp. 2 plates. 26.

* 24 Hrmenoetzar. Claude Morley. 18 pp. $6 a$.

25 Diptera. P. H. Grimsham.

* 26 Lrepdoptrera. W. F. do V. Kane, $10 \mathrm{pp} \cdot 6 \mathrm{~d}$.

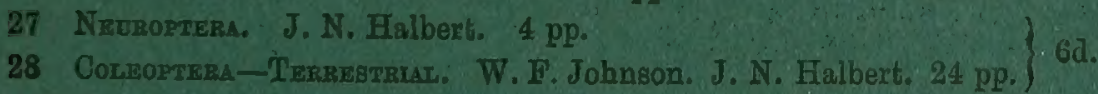

29 Counoptera-Aquatro. F. Balfour Browne. 20 pp. $6 \mathrm{~d}$.

30 Hempters. J. N. Halbert. $10 \mathrm{pp}$.

31 Orreopxera, Prof. G. H. Carpenter, $4 \mathrm{pp}$. $6 \mathrm{~d}$.

[For contimuation see page 4. 
32 Aptera. Prof. G. H. Carpenter.

33 Cricopona axd Dprozoda. Rev. W. F. Johnson.

34. Provogomma Prol, G. B. Oarpenter.

* 85 Araneioa. D, R, Prok Beresford. 8 pp. 16 a.

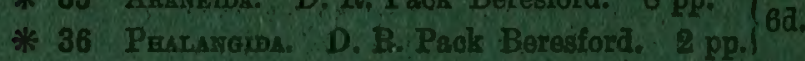

* 87 Arotrisoorn. James Murcay. 16 pp., 8 plates ;

* 88 Pseudoscoratonero. H. Wallis Kew。 $2 \mathrm{pp}$. 18.

* 39 i Acarnimda: i-Hrdracarnia. J. N. Halbert. 44 pp. 8 plates, 2s. 6a.

89 ii OTBER A OARINida. J. N. Halbert.

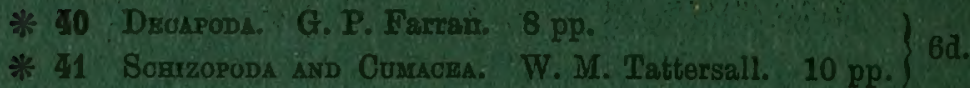

32 Asspampoda. W. M. Tattersah.

* 43 Isopoda-Marunz. W. M. Tattersall. 6 pp. 6 a.

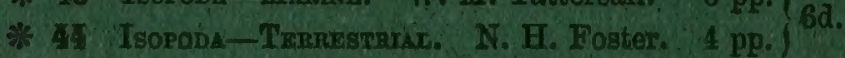

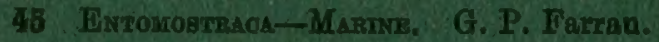

* 46 Enromostraca-Tresawatra. D. J. Scourfield. 18 pp. 1 plate. Ga.

97 Polrobagta and Azomianmerida. R. Southera.

48 Outgoonases. B. Southern.

99 Grphrara, B. Southern.

50 Hrodiven, R. Southern.

* 51 Rotikers (excluding Bderiotoa). C. F. Rousselot. $10 \mathrm{pp}$. 6a.

* 52 Rotifara Bdelioma. James Murray. 20 pp. 1 plate. 6a.

* 53 Pohrzoa A. R. Nichois. 14 pq. 6d.

54 Nematherma and Craetonatea. R. Southern. G. O. Sherrard.

55 Namcontured, B. Southern.

* 56 Pratycikrmu R. Bouthem. $18 \mathrm{pp} .6 \mathrm{~d}$.

57 Eominomermata. A. R. Nichols. $10 \mathrm{pp}$.

58 Combinterata. Miss J. Stephens. $10 \mathrm{pp}$. $6 \mathrm{~d}$.

* 59 Portfera-Martie. Miss J. Stophens. 42 pp. 1 plate. 1s. 6 a.

* 60 Poripgra-Fresinatre. Míss J. Stephens. 18 pp. 1 plate. 6a.

61 Inversona: J. 8. Dunkerly.

62 Fragritiata. J. B. Dunkerly.

* 68 Mycertozod. Miss Listor. 20 pp. 6d.

64. Foraminifara, Edward Heron-Allen. Arthur Earland.

* 65 Rurzopoda and Herrozoa. G. H. Wailes. Eugene Penard. 64 pp. 6 plates. $8 \mathrm{~s}$.

66 Nomes on Marme Pramkrom. G. P. Farran.

67 Sumurary on Marina Dremptbution. R. Southern.

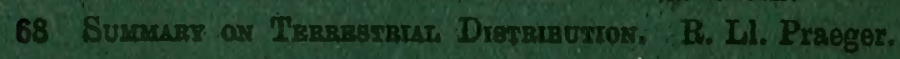



QK

574

I $73 \mathrm{C} 68$

1912

BOT

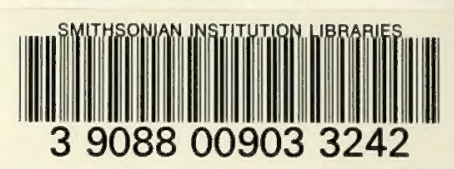

Cotton, A.
Marine Algae. 